MONICA ROTTMANN DE BIAZZI

CONTRIBUIÇÃO PARA O DESENHO ORGANIZACIONAL DE INSTITUIÇÃO PÚBLICA BRASILEIRA:

ESTUDO DE CASO NO SETOR DE SEMICONDUTORES 
MONICA ROTTMANN DE BIAZZI

CONTRIBUIÇÃO PARA O DESENHO ORGANIZACIONAL DE INSTITUIÇÃO PÚBLICA BRASILEIRA:

ESTUDO DE CASO NO SETOR DE SEMICONDUTORES

Tese apresentada à Escola Politécnica da Universidade de São Paulo para obtenção do título de Doutor em Engenharia 
Monica Rottmann de Biazzi

\section{CONTRIBUIÇÃO PARA O DESENHO ORGANIZACIONAL \\ DE INSTITUIÇÃO PÚBLICA BRASILEIRA: \\ ESTUDO DE CASO NO SETOR DE SEMICONDUTORES}

Tese apresentada à Escola Politécnica da Universidade de São Paulo para obtenção do

Título de Doutor em Engenharia

Área de Concentração:

Engenharia de Produção

Aprovada Em:

Banca Examinadora

Prof. Dr.:

Instituição:

Assinatura:

Prof. Dr.:

Instituição:

Assinatura:

Prof. Dr.:

Instituição:

Assinatura:

Prof. Dr.:

Instituição:

Assinatura:

Prof. Dr.:

Instituição: Assinatura: 
MONICA ROTTMANN DE BIAZZI

CONTRIBUIÇÃO PARA O DESENHO ORGANIZACIONAL DE INSTITUIÇÃO PÚBLICA BRASILEIRA:

ESTUDO DE CASO NO SETOR DE SEMICONDUTORES

Tese apresentada à Escola Politécnica da Universidade de São Paulo para obtenção do título de Doutor em Engenharia

Área de Concentração:

Engenharia de Produção

Orientador:

Prof. Dr. Antonio Rafael Namur Muscat 
Este exemplar foi revisado e alterado em relação à versão original, sob responsabilidade única do autor e com a anuência de seu orientador.

São Paulo, de junho de 2012.

Assinatura do autor

Assinatura do orientador

FICHA CATALOGRÁFICA

\section{Biazzi, Monica Rottmann de}

Contribuição para o desenho organizacional de instituição pública brasileira: estudo de caso no setor de semicondutores /

M.R. de Biazzi. -- ed.rev. -- São Paulo, 2012.

$211 \mathrm{p}$.

Tese (Doutorado) - Escola Politécnica da Universidade de São Paulo. Departamento de Engenharia de Produção.

1.Estrutura organizacional 2.Teoria de sistemas 3.Setor público 4.Semicondutores I.Universidade de São Paulo. Escola Politécnica. Departamento de Engenharia de Produção II.t. 
Dedico este trabalho ao Jorge

e aos nossos filhos, Betina e Ricardo, razão de minha vida. 


\section{AGRADECIMENTOS}

Muitos foram os que contribuíram para a realização deste trabalho. De uma forma especial, gostaria de deixar meus sinceros agradecimentos:

Em primeiro lugar, a Deus, por mais uma vez ter me dado forças e saúde para chegar até aqui. "É o Senhor quem dá sabedoria; a sabedoria e o entendimento vêm dele" Pv. 2:6.

Aos meus pais, Mariza e Martinho, e a todos os meus familiares: Antonieta e Fábio, irmãos, cunhados e sobrinhos, pelo apoio e incentivo.

Ao professor Antonio Rafael Namur Muscat, meu orientador, e aos professores Marilson Alves Gonçalves e Fernando José Barbin Laurindo, pela colaboração durante a elaboração deste trabalho.

Aos professores das disciplinas cursadas e aos funcionários da Escola Politécnica, que de diferentes formas contribuíram para a realização deste trabalho.

Aos meus colegas da pós-graduação, pelo constante apoio em tempos difíceis e pelos valiosos conselhos dados. 
"Equilíbrio é a habilidade de olhar para a vida a partir de uma perspectiva clara - fazer a coisa certa no momento certo. Uma pessoa equilibrada será capaz de apreciar a beleza e o significado de cada situação, seja ela adversa ou favorável. Equilíbrio é a habilidade de aprender com a situação e de prosseguir com sentimentos positivos. É estar sempre alerta, ser totalmente focado, e ter uma visão ampla. Equilíbrio vem do entendimento, humildade e tolerância. O mais elevado estado de equilíbrio é voar livre de tudo e, ainda assim, manter-se firmemente enraizado na realidade do mundo."

(Brahma Kumaris) 


\section{RESUMO}

Nas últimas décadas, o domínio tecnológico tem sido enfatizado como elemento de progresso tanto no âmbito das empresas como no dos países. A tecnologia está presente na infra-estrutura das atividades econômicas e de toda a sociedade. Dessa forma, a tecnologia da informação é cada vez mais importante para o desenvolvimento tecnológico, mesmo em áreas não diretamente ligadas a ela. O setor de semicondutores, que em conjunto com os setores de computação e de software forma a indústria de microeletrônica, tem tido especial destaque na evolução da economia mundial. No Brasil, entretanto, o setor de semicondutores permanece restrito a um pequeno grupo de empresas. Neste contexto, com o propósito de desenvolver o setor de microeletrônica no Brasil, o governo federal, por meio do Ministério da Ciência, Tecnologia e Inovação, investiu na criação de uma empresa de semicondutores, no estado do Rio Grande do Sul. A empresa criada constitui o objeto de pesquisa deste estudo de caso, desenvolvido ao longo de 2011 , com foco em seu desenho organizacional. Os objetivos alcançados com o presente trabalho foram os seguintes: levantamento dos modelos de desenho organizacional na literatura, tanto do setor privado como do setor público; estudo das características administrativas de instituições públicas brasileiras, sua forma de operar e seu desenho organizacional, considerando suas várias dimensões; levantamento das características do setor de semicondutores, com foco no surgimento de empresas deste setor em países em desenvolvimento; avaliação das diferentes dimensões do desenho organizacional, suas interdependências e equilíbrios dinâmicos, por meio de um estudo de caso, considerando a realidade de empresa pública brasileira. A metodologia utilizada foi o estudo de caso, com abordagem qualitativa. A coleta de dados foi realizada por meio de observação direta, análise documental e entrevistas semiestruturadas. A principal contribuição deste trabalho consiste na análise do desenho organizacional adotado pela empresa em estudo, considerando a organização de uma maneira integrada e sistêmica, incluindo todas as cinco dimensões do desenho organizacional - Estratégia, Pessoas, Sistemas de Recompensa, Processos e Estrutura -, além de identificar as interações entre as diversas dimensões e entre estas e o ambiente de atuação da empresa. Outra 
contribuição do presente trabalho está relacionada à análise da evolução dos subsistemas produtivos na organização ao longo do tempo, assim como a evolução dos objetivos de desempenho a serem buscados pela empresa. Considerando que os estudos acadêmicos sobre desenho organizacional no setor público brasileiro são relativamente escassos, os resultados obtidos neste trabalho consistem em contribuição para a teoria, uma vez que abrangem fatores específicos do setor público e sua influência sobre programas de reestruturação e mudança. Além disso, diante da grande necessidade de melhoria do setor, a descrição do caso e a análise dos resultados apresentam evidente aplicação prática, uma vez que proporcionam uma base para trabalhos futuros.

Palavras-chave: Desenho Organizacional. Equilíbrio Dinâmico. Setor Público. Semicondutores. 
In the last decades, technological dominium has been emphasized as a progress element even in the ambit of firms as of countries. Technology is present in the infrastructure of economic activities as in the whole society. In this way, information technology is being each time more important to technological development, even in areas not directly linked to it. The semiconductor sector, which forms the microelectronic industry together with computer and software sectors, has received special highlight in the evolution of the world economy. In Brazil, however, the semiconductor sector remains restricted to a small group of firms. In this context, with the propose of developing the microelectronic sector in Brazil, the federal government, through the Science, Technology and Innovation Ministry, invested in the creation of a semiconductor firm, in Rio Grande do Sul state. The created firm consists in the research object of this study case, developed along 2011, with focus on its organizational design. The objectives reached with the present work were: identification of organizational design models in the literature, both of the private and the public sectors; study of administrative characteristics of Brazilian public institutions, their modus operandi and organizational design, considering its various dimensions; identification of semiconductors characteristics, with focus on the emerging of firms in this sector in developing countries; evaluation of different dimensions of organizational design, its interdependencies and dynamic equilibrium, through a study case, considering the reality of a Brazilian public firm. The methodology used was case study, with qualitative approach. Data were collected through direct observation, documental analysis and semi-structured interviews. The main contribution of this work is the analysis of the organizational design adopted by the studied firm, considering the organization in an integrated and systemic manner, including all the five dimensions of its organizational design - Strategy, People, Reward Systems, Process and Structure -, besides identifying the interactions between these dimension and between each dimensions and the organization's environment. Another contribution of this work is related to the analysis of the evolution of the productive subsystems in the organization along the time, so as the evolution of the performance objectives to be reached by the firm. Considering that 
academic studies about organizational design in the Brazilian public sector are relatively scarce, the results obtained in this work consist of contribution to theory, since they enclose specific aspects of the public sector and their influence in restructuring and change programs. Moreover, given the major need for improvement of the sector, the case description and the analysis of the results present evident practical application, because they provide a base for future work.

Keywords: Organization Design. Dynamic Equilibrium. Public Sector. Semiconductors. 


\section{LISTA DE ILUSTRAÇÕES}

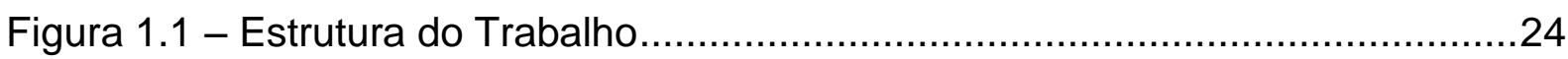

Figura 2.1 - Forças que dirigem a concorrência em um Setor Industrial ..................28

Figura 2.2 - Cadeia Produtiva de Semicondutores .............................................29

Figura 2.3 - Desenho Organizacional (Modelo da "Estrela").....................................39

Figura 2.4 - Representação de Processo de Trabalho .........................................54

Figura 2.5 - Inter-relacionamento entre os tipos de processos ..............................55

Figura 2.6 - Estrutura Organizacional Vertical (Funcional) ....................................60

Figura 2.7 - Estrutura Organizacional Horizontal (por Processo) ...........................61

Figura 2.8 - Esquema de Estrutura Matricial (Funcional x Processos) ......................62

Figura 2.9 - As cinco partes básicas da organização ...........................................64

Figura 2.10 - Complementaridade das abordagens de melhoria contínua e

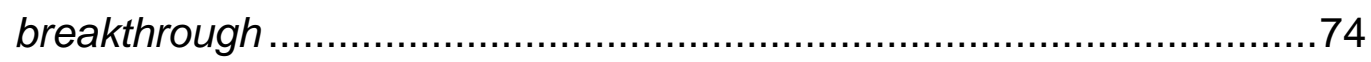

Figura 2.11 - Equilíbrios Dinâmicos do Desenho Organizacional ............................91

Figura 4.1 - Linha do Tempo da Organização A ………....................................99

Figura 4.2 - Estrutura de Macroprocessos da Organização A ...............................139

Figura 5.1 - Subsistemas de um Sistema Produtivo ..........................................162

Figura 5.2 - Desenho Organizacional dos Subsistemas de um Sistema Produtivo 164

Figura 5.3 - Subsistemas da Organização A - Fase 1 .........................................166

Figura 5.4 - Subsistemas da Organização A - Fase 2 …...................................167

Figura 5.5 - Subsistemas da Organização A - Fase 3 ……...............................168 


\section{LISTA DE TABELAS}

Tabela 4.1 - Valores Salariais Mensais para Nível Superior - Especialistas..........124

Tabela 4.2 - Valores Salariais Mensais para Nível Superior - Analista ..................124

Tabela 4.3 - Valores Salariais Mensais para Nível Médio - Técnicos ....................125

Tabela 4.4 - Valores Salariais Mensais para Nível Médio - Suporte e Operacional 


\section{LISTA DE QUADROS}

Quadro 2.1 - Comparativo dos Incentivos Governamentais para a Indústria de Componentes de Microeletrônica.......................................................34

Quadro 2.2 - Principais Players do Setor de Semicondutores no Brasil ...................37

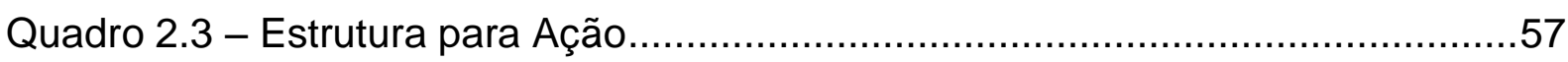

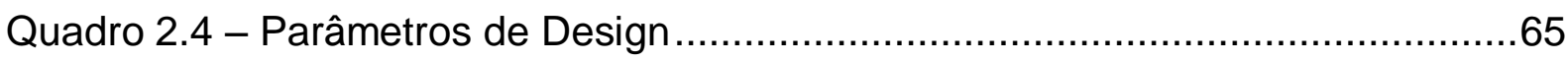

Quadro 2.5 - As Cinco Configurações Básicas.....................................................66

Quadro 2.6 - Os cinco "R's" da Nova Gerência Pública .........................................79

Quadro 5.1 - Análise da Mudança nas Dimensões do Desenho Organizacional da

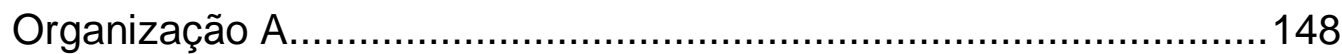

Quadro 5.2 - Interação entre as Dimensões dos Subsistemas Produtivos da

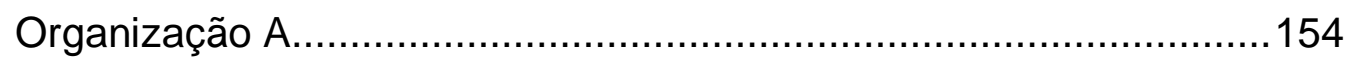

Quadro 5.3 - Evolução do Sistema Produtivo da Organização A ..........................165 


\section{LISTA DE ABREVIATURAS E SIGLAS}

ABINEE Associação Brasileira da Indústria Elétrica e Eletrônica

APR Arranjo Produtivo Regional

BSC Balanced Scorecard

CMOS Complementary Metal-oxide Semiconductor

DEST Departamento de Coordenação e Governança das Empresas Estatais

DRAMS Dynamic Random-access Memory

ERP Enterprise Resource Planning

FCS Fator Crítico de Sucesso

FUNDAP Fundação do Desenvolvimento Administrativo

IC

Circuito Integrado

IT

Instruções de Trabalho

NGP Nova Gestão Pública

NPM New Public Management

MRP Materials Requirements Planning

MRP II Manufacturing Resources Planning

PBQP Programa Brasileiro de Qualidade e Produtividade

PC Computadores Pessoais

PCCR Plano de Cargos, Carreiras e Remuneração

P\&D Pesquisa e Desenvolvimento

PFC Plano de Funções em Comissão

PQSP Programa da Qualidade no Serviço Público

QPAP Programa da Qualidade e Participação na Administração Pública

RFID Radio-Frequency Identification

SI Sistema de Informação

SIA Semiconductor Industry Association

SSM Soft Systems Methodology

TI Tecnologia da Informação

TITC Tecnologia de Informação e Telecomunicações

TQM Total Quality Management

VLSI Very-Large-Scale Integration 


\section{SUMÁRIO}

1 INTRODUÇÃO, JUSTIFICATIVA E OBJETIVOS DO TRABALHO …....................19

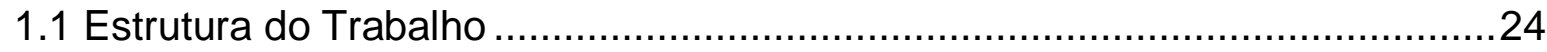

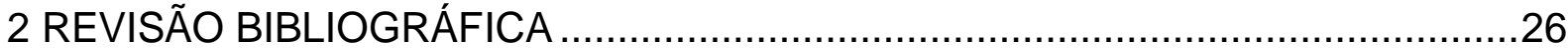

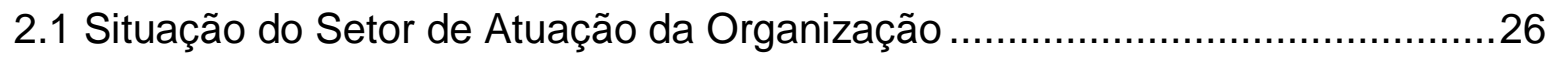

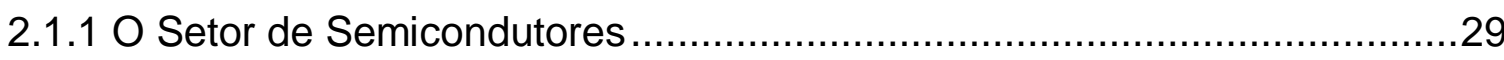

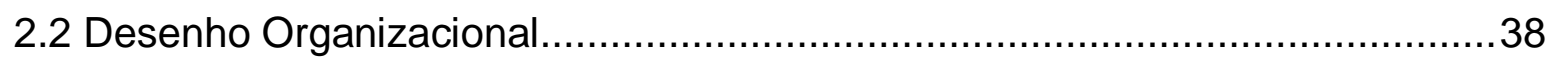

2.2.1 Dimensão Estratégia........................................................................ 44

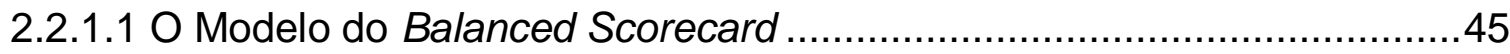

2.2.1.2 BSC no Setor Público ……................................................................ 48

2.2.2 Dimensão Pessoas ......................................................................... 49

2.2.3 Dimensão Sistemas de Recompensa ...................................................52

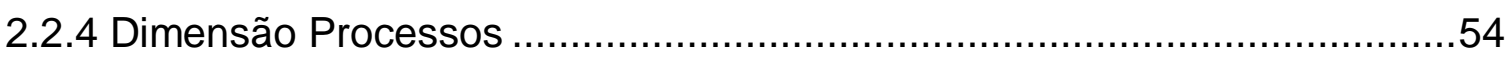

2.2.5 Dimensão Estrutura Organizacional (Organograma) …...........................60

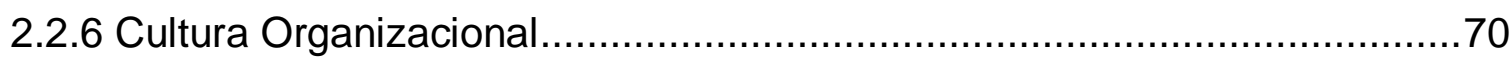

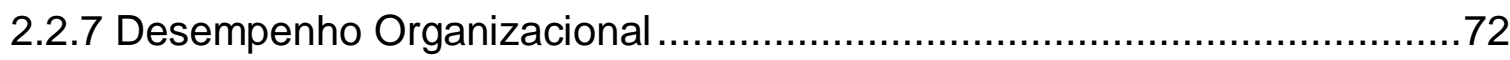

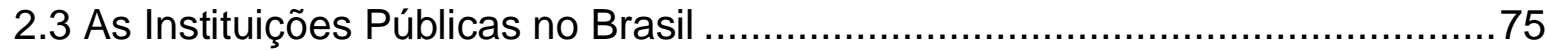

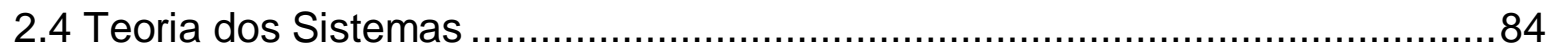

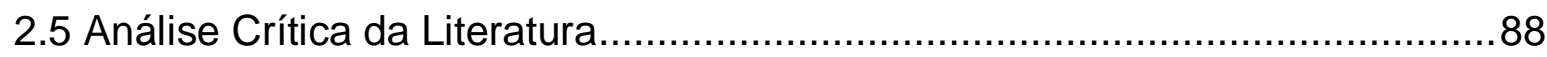

3 METODOLOGIA

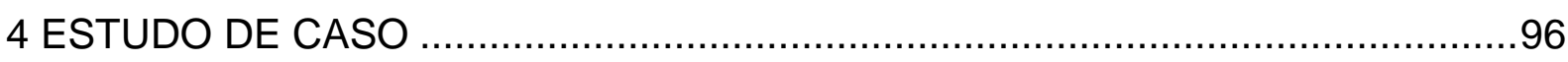

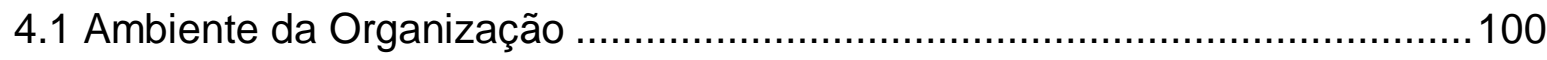

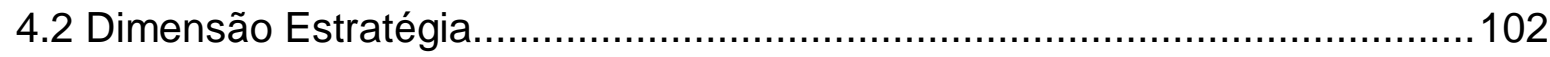

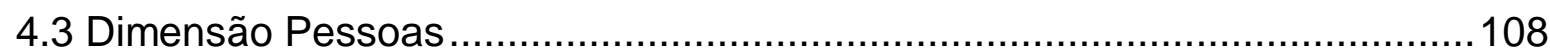

4.4 Dimensão Sistemas de Recompensa .................................................116

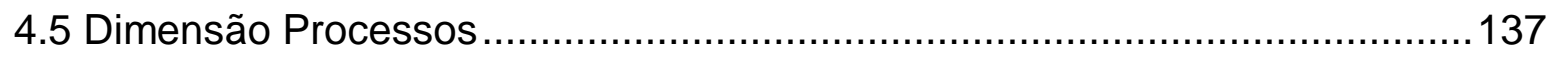

4.6 Dimensão Estrutura Organizacional (Organograma) …..............................144

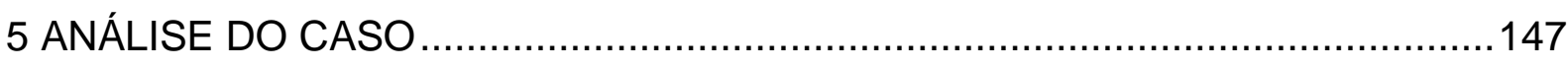

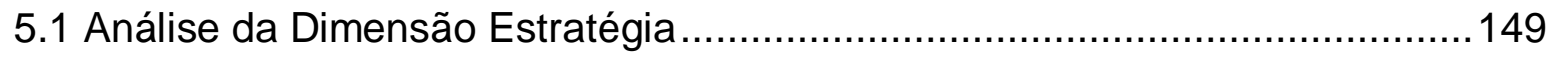

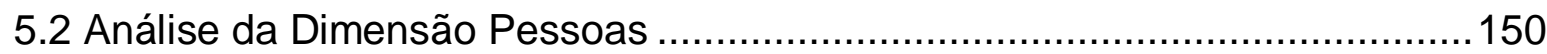

5.3 Análise da Dimensão Sistemas de Recompensa .....................................150

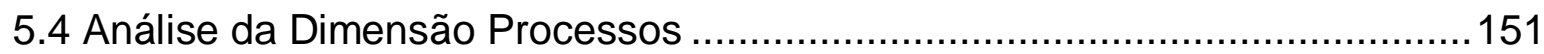


5.5 Análise da Dimensão Estrutura Organizacional ........................................152

5.6 Interação entre as Dimensões do Desenho Organizacional .........................153

5.7 Subsistemas Produtivos da Organização A .................................................162

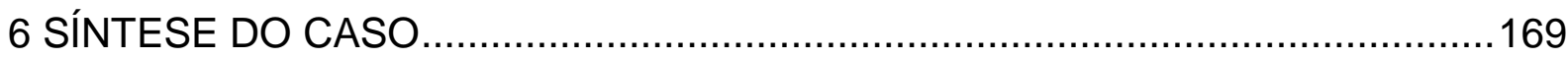

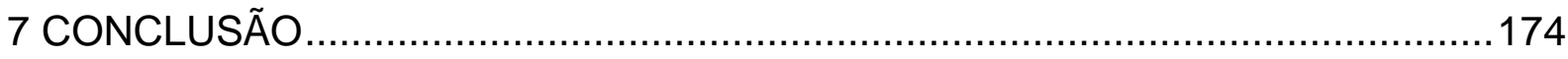

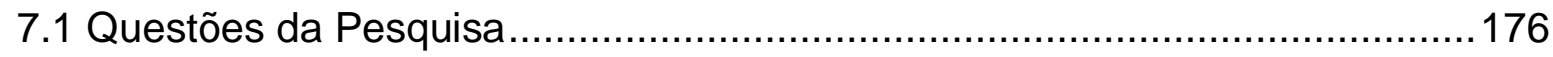

7.2 Limitações da Pesquisa e Extensões dos Resultados Obtidos ....................180

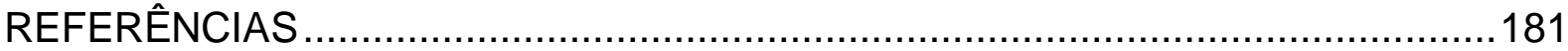

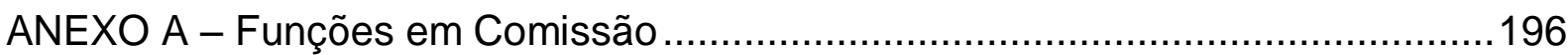

ANEXO B - Desdobramento de Macroprocessos em Processos e Subprocessos. 197

ANEXO C - Lista de Processos e Subprocessos Priorizados................................205

ANEXO D - Organograma Geral Inicial da Organização A ...................................207

ANEXO E - Organograma Inicial do Setor Administrativo-Financeiro ....................208

ANEXO F - Organograma Inicial do Setor de Marketing ….................................209

ANEXO G - Organograma Inicial do Setor de Design ........................................210

ANEXO H - Organograma Inicial do Setor de Fábrica........................................211 


\section{INTRODUÇÃO, JUSTIFICATIVA E OBJETIVOS DO TRABALHO}

O setor de microeletrônica, representado pelos setores de semicondutores, de computação e de software, nasceu no período pós Segunda Guerra Mundial (MOWERY e NELSON, 1999). A história da indústria da computação apresenta períodos em que as grandes empresas produtoras eram verticalmente integradas, desenhando e produzindo seus próprios componentes eletrônicos, e apresenta períodos em que mesmo os grandes produtores adquiriam esses componentes de fornecedores especializados (MALERBA, NELSON, ORSENIGO e WINTER, 2008). Entre os componentes para a produção de computadores, os principais sempre foram os semicondutores. Em grande parte, o significativo aumento da capacidade computacional e a redução em seus custos foram possíveis através dos tempos devido aos avanços da tecnologia dos semicondutores. Conforme demonstrado pelos trabalhos de Malerba et al (2008), a indústria da computação e a de semicondutores têm sua evolução extremamente associada. A análise da evolução do setor de semicondutores tem sido o foco de atenção de vários pesquisadores (DIBIAGGIO, 2007; KAPOOR e ADNER, 2007; CLENDENIN, 2007; MALERBA et al, 2008b; LI, HUANG e CHEN, 2010). Entre os aspectos que contribuíram para o desenvolvimento do setor, podem-se citar: a importância da demanda dos usuários finais, os efeitos das estratégias e da estrutura do setor e o papel das políticas governamentais. No Brasil, podem ser citados os trabalhos de Amato et al (2002) e Carvalho (2006), que visam analisar as condições de desenvolvimento da indústria brasileira de semicondutores, e de Laurindo e Carvalho (2003), que tem o objetivo de investigar o impacto de aspectos como outsourcing, inovação, valor e evolução da indústria de computadores pessoais (PCs) na competitividade da indústria de PCs do Brasil e as repercussões para seu crescimento e inserção no mercado global.

Neste contexto, em 2008, com o propósito de desenvolver o setor de microeletrônica no Brasil, o governo federal, por meio do Ministério da Ciência, Tecnologia e Inovação, investiu na criação de uma empresa de semicondutores. Com a criação desta empresa, o governo brasileiro teve a intenção, inclusive, de fomentar o desenvolvimento de um arranjo produtivo regional (APR), além de 
desenvolver competências específicas para o setor. O incentivo governamental para a formação de arranjos produtivos para o desenvolvimento regional tem sido discutido por vários autores (PORTER, 2009; DANSON, 2009; HERRSCHEL, 2009; NEWMAN, 2009; TODOROVICH, 2009). Segundo Porter (2009), arranjos produtivos, também chamados de "clusters", podem ser definidos como concentrações geográficas de empresas de determinado setor de atividade e organizações correlatas, de fornecedores de insumos a instituições de ensino e clientes. Os clusters provocam tanto a concorrência como a cooperação: as empresas continuam disputando o mesmo mercado, mas cooperam em aspectos que trazem ganhos mútuos, como por exemplo, participação em feiras, consórcio de exportação, compartilhamento de fretes e tratamento de matéria prima, aumentando a produtividade das empresas sediadas na região, indicando a direção e o ritmo da inovação, que sustentam o futuro crescimento da produtividade, e estimulando a formação de novas empresas, o que expande e reforça o próprio cluster.

Considerando o papel fundamental que as políticas governamentais tiveram na evolução do setor em países como Estados Unidos e Japão, a iniciativa do governo brasileiro de criar uma empresa de semicondutores mostra-se como positiva, constituindo um embrião para o desenvolvimento deste setor. A organização criada, uma empresa pública, representa um empreendimento único no Brasil no setor de semicondutores. Na época da presente pesquisa, estava em fase de instalação e certificação de seus equipamentos operacionais, ou seja, ainda não estava em fase de operação. Enquanto suas instalações industriais estavam sendo montadas, os gestores buscavam definir sua estratégia de atuação e seu planejamento estratégico, além de haver necessidade de desenhar sua forma de operação. Em tal cenário, a empresa apresentava grande necessidade de definição de seu desenho organizacional.

O desenho organizacional pode ser definido como a estrutura que uma organização adota para a execução de sua estratégia. Segundo Galbraith (2009), o conceito de desenho organizacional resulta da combinação da definição de organização com o conceito de opção estratégica. Uma organização é composta por pessoas e grupos de pessoas que trabalham para atingir um objetivo comum, através da divisão do trabalho, integrado por processos de decisão baseados em informação, continuamente ao longo do tempo. O desenho organizacional é 
concebido como um processo de decisão que proporcione coerência entre metas e propósitos para os quais a organização existe, os padrões de divisão e coordenação do trabalho e as pessoas que irão trabalhar. A noção de opção estratégica sugere que existem opções de metas e propósitos, opções de modos de organização, opções de processos para integração dos indivíduos na organização e, finalmente, opções de como metas, modos de organização, indivíduos ou alguma combinação entre eles devem ser mudados para se adaptar às mudanças do ambiente. Galbraith (2009) propõe um modelo de desenho organizacional (modelo da estrela) composto por cinco dimensões, a saber: estratégia, pessoas, sistemas de recompensa, processos e estrutura organizacional (organograma). Estas cinco dimensões são interdependentes e estão em constante equilíbrio dinâmico, devendo ser desenhadas de forma a se atingir a estratégia adotada pela organização. A ideia de alinhamento entre as cinco dimensões do desenho organizacional é fundamental, uma vez que quanto mais a estratégia, as pessoas, as recompensas, os processos e a estrutura reforçarem as ações e os comportamentos desejados, maiores serão as chances da organização ser capaz de atingir seus objetivos.

Ao longo das últimas décadas, as organizações públicas também se viram sob maior pressão para melhorar seu desempenho e demonstrar maior transparência e avaliação de resultados, o que resultou na busca de melhorias em sua forma de operar. Várias estratégias de atuação têm sido adotadas por diferentes instituições públicas, geralmente utilizando práticas gerenciais do setor privado. Considerando que a empresa do presente estudo constitui uma empresa pública, a simples adoção de um desenho organizacional de empresa privada do setor de semicondutores, no entanto, não se mostrava adequada, uma vez que várias características específicas do setor público exercem influência sobre sua forma de gestão, seu desenho organizacional ou programas de mudança, como a existência de legislação específica a ser seguida, hierarquias rígidas, a cultura do setor, mudanças periódicas de direção, entre outras.

Embora a literatura acadêmica apresente vários trabalhos relacionados ao setor público no mundo, os pesquisadores geralmente focam as dimensões do desenho organizacional individualmente, ao invés de analisarem as dimensões de uma forma integrada e interdependente. Há trabalhos relacionados à dimensão estratégia (McADAM, WALKER e HAZLETT, 2011), à dimensão pessoas (VIGODA- 
GADOT, 2006; BELLOU, 2009; GRÖENEVELD, 2011; TROSHANI e JERRAM, 2011), à dimensão processos (HELLSTRÖM e PETERSON, 2006) e à dimensão estrutura organizacional (MALLAK e WATTS, 1997; OTHMAN e SAID, 2007; RYAN, 2008; ALDAMA, AMAR e TROSTIANKI, 2009). Alguns autores focam a questão da cultura organizacional do setor público (SCHRAEDER, TEARS e JORDAN, 2005) e a gestão de custos para obtenção de melhores resultados (VERBEETEN, 2011; LUKE, KEARINS e VERREYNNE, 2011). A literatura acadêmica sobre o setor público brasileiro é mais escassa, focando muitas vezes, também, nas dimensões do desenho organizacional de forma individual. Há trabalhos que estudam a dimensão pessoas (JACKSON FILHO, 2004; BAHRY e TOLFO, 2007; ROCHA e SILVA, 2007; UBEDA e SANTOS, 2008; VILLARDI, FERRAZ e DUBEUX, 2011) e a dimensão processos (RUTKOWSKI, 1998; VAZ e LOTTA, 2011). Há autores que focam na questão da utilização da tecnologia da informação no setor público (BECKER, LUNARDI e MAÇADA, 2003; LEITE e REZENDE, 2010), bem como autores que focam a estrutura e modelos de governança e gestão (FONTES FILHO e PICOLIN, 2008; LOPES e BALDI, 2009; SECCHI, 2009; GARCIA e SALLES FILHO, 2009). Alguns trabalhos buscam integrar mais de uma dimensão, como no caso de Costa, Salles e Fontes Filho (2010), que associam a dimensão estratégica com o sistema de recompensas, e o trabalho de Brandão et al (2008), que integra a dimensão estratégica com a dimensão pessoas. Alguns autores conduziram pesquisas em empresas privadas do setor de semicondutores, estudando aspectos relacionados à dimensão pessoas (OOl et al, 2007).

O grande desafio para a administração atual consiste em obter uma compreensão clara e profunda das organizações em sua totalidade, de seu funcionamento e de como gerenciá-las de uma forma sistêmica. Esta compreensão depende do conhecimento de características particulares do desenho organizacional de cada organização. Nesse sentido, a iniciativa do governo federal de criar uma empresa de semicondutores proporciona uma oportunidade singular para se desenvolver tais pesquisas no setor público. No caso específico de instituições públicas, onde há uma constante alternância nos altos cargos administrativos, a iniciativa de se definir e registrar as diferentes dimensões do desenho organizacional, de forma a evidenciar suas interdependências e o equilíbrio dinâmico existente entre estas dimensões, resulta em um significativo benefício administrativo. 
Uma vez que os relatos na literatura sobre desenho organizacional nas organizações públicas no Brasil são mais escassos, justifica-se uma pesquisa sobre a empresa criada, considerando as características e peculiaridades da instituição em estudo.

Neste contexto, este trabalho tem como objeto de estudo a criação de uma empresa pública do setor de semicondutores, com foco em seu desenho organizacional. Pretende-se alcançar os seguintes objetivos:

(a) Levantar na literatura os modelos de desenho organizacional desenvolvidos para organizações em geral, tanto do setor privado como do setor público;

(b) Estudar as características administrativas de instituições públicas brasileiras, sua forma de operar e seu desenho organizacional, considerando suas várias dimensões: estratégia, pessoas, sistemas de recompensa, processos e estrutura organizacional (organograma);

(c) Levantar as características do setor de semicondutores, com foco no surgimento de empresas deste setor em países em desenvolvimento;

(d) Avaliar as diferentes dimensões do desenho organizacional - estratégia, pessoas, sistemas de recompensa, processos e estrutura organizacional (organograma) - suas interdependências e equilíbrios dinâmicos, por meio de um estudo de caso desenvolvido em empresa pública de semicondutores no Brasil, considerando a realidade do setor público brasileiro.

Considerando que esta pesquisa tem como objeto de estudo uma instituição pública brasileira, deve-se notar que o tema "administração pública" será abordado de forma a se obter casos anteriores no setor público para comparação e análise, porém de forma tangencial e resumida, uma vez que o foco principal é o desenho organizacional, em suas diversas dimensões, na abordagem da engenharia de produção. Os produtos deste trabalho - o estudo de caso e a análise dos resultados obtidos - podem vir a ser utilizados em pesquisas relacionadas ao tema abordado e em projetos futuros, tanto por profissionais da área de consultoria organizacional como por profissionais atuantes em organizações públicas.

A Figura 1.1, apresentada a seguir, mostra a estrutura de trabalho que será adotada nesta pesquisa. 


\subsection{Estrutura do Trabalho}

Será utilizada a estrutura de trabalho representada na Figura 1.1:

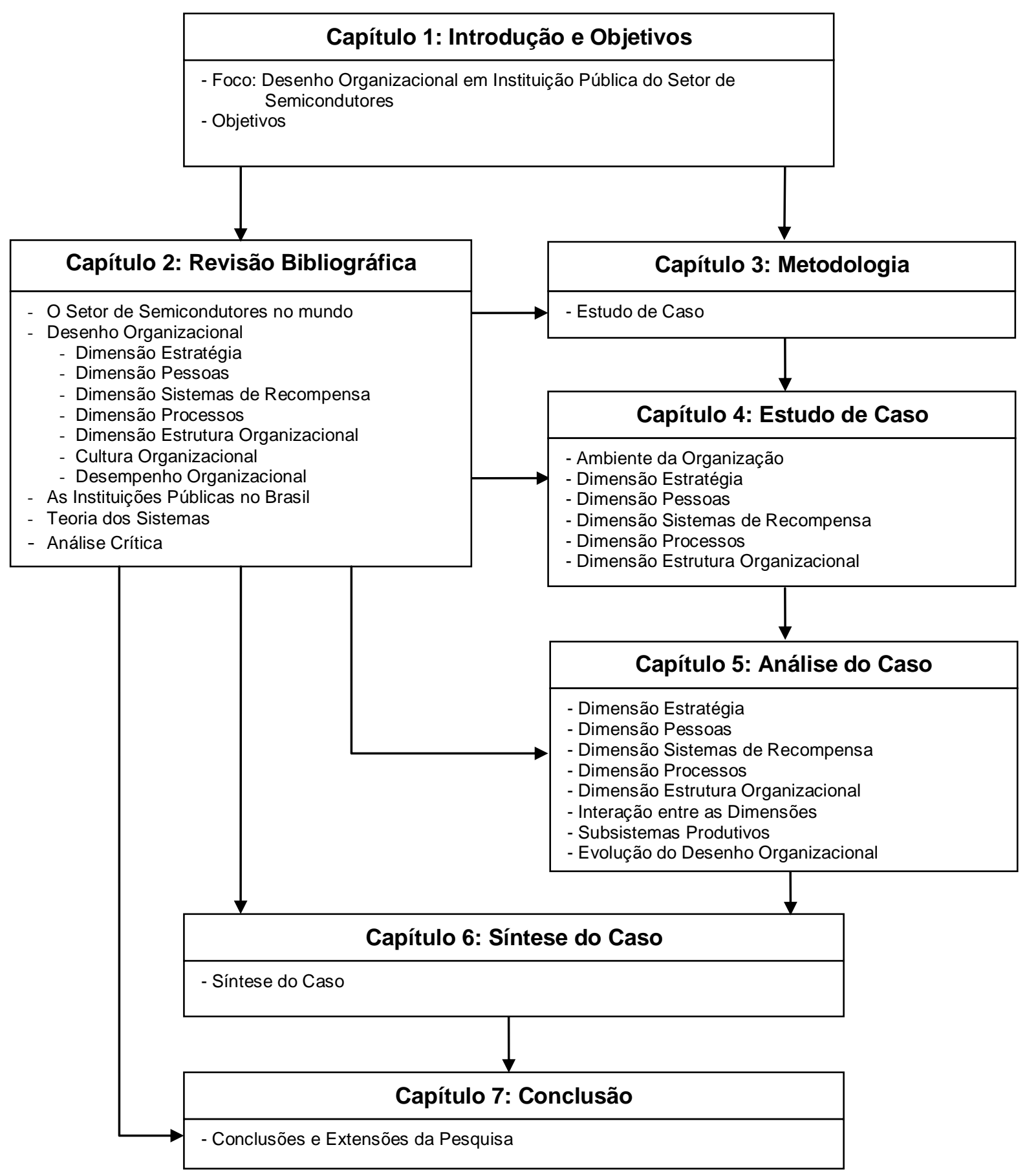

Figura 1.1 - Estrutura do Trabalho

Fonte: Elaborada pela autora 
Conforme apresentado na Figura 1.1, o primeiro capítulo do presente trabalho contextualiza o tema que será abordado, desenho organizacional, considerando o setor de semicondutores e a realidade do setor público brasileiro, além de apresentar os objetivos da pesquisa e o foco do trabalho. No primeiro capítulo também é apresentada a estrutura do trabalho.

No segundo capítulo é realizada uma revisão bibliográfica sobre os assuntos que serão abordados no trabalho: uma breve revisão sobre o setor de semicondutores no mundo e no Brasil; desenho organizacional e seus elementos componentes (dimensões); uma revisão sobre as instituições públicas brasileiras e suas características, teoria dos sistemas e, por fim, uma análise crítica dos assuntos abordados, visando identificar lacunas a serem exploradas na presente pesquisa.

No terceiro capítulo é apresentada a metodologia adotada nesta pesquisa, relatando em linhas gerais os métodos e técnicas utilizados, bem como os instrumentos de coleta e análise de dados.

O quarto capítulo apresenta uma descrição do caso estudado, fornecendo detalhes de cada uma das dimensões do desenho organizacional da empresa estudada.

No quinto capítulo é realizada uma análise aprofundada dos dados coletados, considerando cada dimensão do desenho organizacional, bem como a interação entre as mesmas e com o ambiente. É realizada, também, uma análise dos vários subsistemas que compõem o desenho organizacional da empresa em estudo, assim como uma análise da evolução dos subsistemas ao longo do tempo.

O sexto capítulo apresenta uma síntese da análise executada no presente estudo de caso e o sétimo e último capítulo apresenta as conclusões finais deste trabalho, assim como limitações da pesquisa e perspectivas para sua continuidade. 


\section{REVISÃO BIBLIOGRÁFICA}

Para a análise do desenho organizacional a ser realizada nesta pesquisa, será feita inicialmente uma revisão sobre a evolução do setor de atuação da empresa em estudo (semicondutores), desde seus primórdios até os dias atuais. Em seguida, será estudado de forma detalhada o conceito de desenho organizacional, foco do presente trabalho, considerando suas diferentes dimensões - estratégia, pessoas, sistemas de recompensa, processos e estrutura organizacional (organograma). Considerando que o desenho organizacional tem impacto na formação da cultura da organização, será revisado o conceito de cultura organizacional. Em seguida, como os resultados de uma organização dependem do desenho organizacional que ela adota, será revisado o conceito de desempenho organizacional. A seguir, considerando que se pretende analisar o desenho organizacional de uma empresa pública brasileira, será realizada uma revisão das principais características das instituições públicas brasileiras. Com o objetivo de se obter uma visão global, integrando as várias dimensões do desenho organizacional, será dado um enfoque sistêmico à análise desenvolvida neste trabalho. Para isso, será realizada uma breve revisão sobre a teoria dos sistemas e os principais pesquisadores que se preocuparam em obter soluções globais para o sistema de produção. Por fim, será feita uma análise crítica dos trabalhos encontrados na literatura sobre desenho organizacional, avaliando as limitações existentes e possíveis aspectos a serem explorados com mais atenção na presente pesquisa.

\subsection{Situação do Setor de Atuação da Organização}

Antes de definir seu desenho organizacional, toda organização deve estudar a situação do setor em que atua, analisando os elementos e forças do ambiente em que está inserida (HANNA, 1988). O ambiente apresenta necessidades que a organização precisa satisfazer e ainda exerce pressões que devem ser gerenciadas, podendo-se citar: resultados esperados; expectativas corporativas, tais como orçamentos, padrões de crescimento, taxas de retorno, desenvolvimento de 
tecnologias e de pessoas; expectativas sociais, políticas ou legais; pressões competitivas, tais como inovação de produtos ou competição por preços; expectativas dos funcionários e seus familiares com relação a segurança no trabalho, carreira, níveis de participação e salários.

A situação do setor de atuação da organização está ligada à estratégia organizacional. Esta ligação evidencia o quanto uma organização é consciente das forças existentes no ambiente em que atua. Uma organização que ignore seu ambiente provavelmente apresentará vários pontos críticos em sua estratégia organizacional, deixando de perceber novas tendências ou expectativas críticas para sua sobrevivência. Já uma organização que reconhece sua dependência do ambiente fará o possível para implantar estratégias e políticas apropriadas à medida que as condições ambientais mudarem. A estratégia implantada será, portanto, um "contrato" com o ambiente, que garantirá sua sobrevivência.

Segundo Porter (2004), a essência da formulação de uma estratégia competitiva é relacionar uma empresa ao seu ambiente. Embora o ambiente seja muito amplo, abrangendo tanto forças sociais como econômicas, o aspecto principal do ambiente da empresa é o setor ou os setores industriais em que ela compete. $O$ grau da concorrência em uma indústria depende de cinco forças competitivas básicas - entrada de novas empresas, ameaça de produtos ou serviços substitutos, poder de negociação de compradores, poder de negociação de fornecedores e rivalidade entre os atuais concorrentes - representadas na Figura 2.1: 


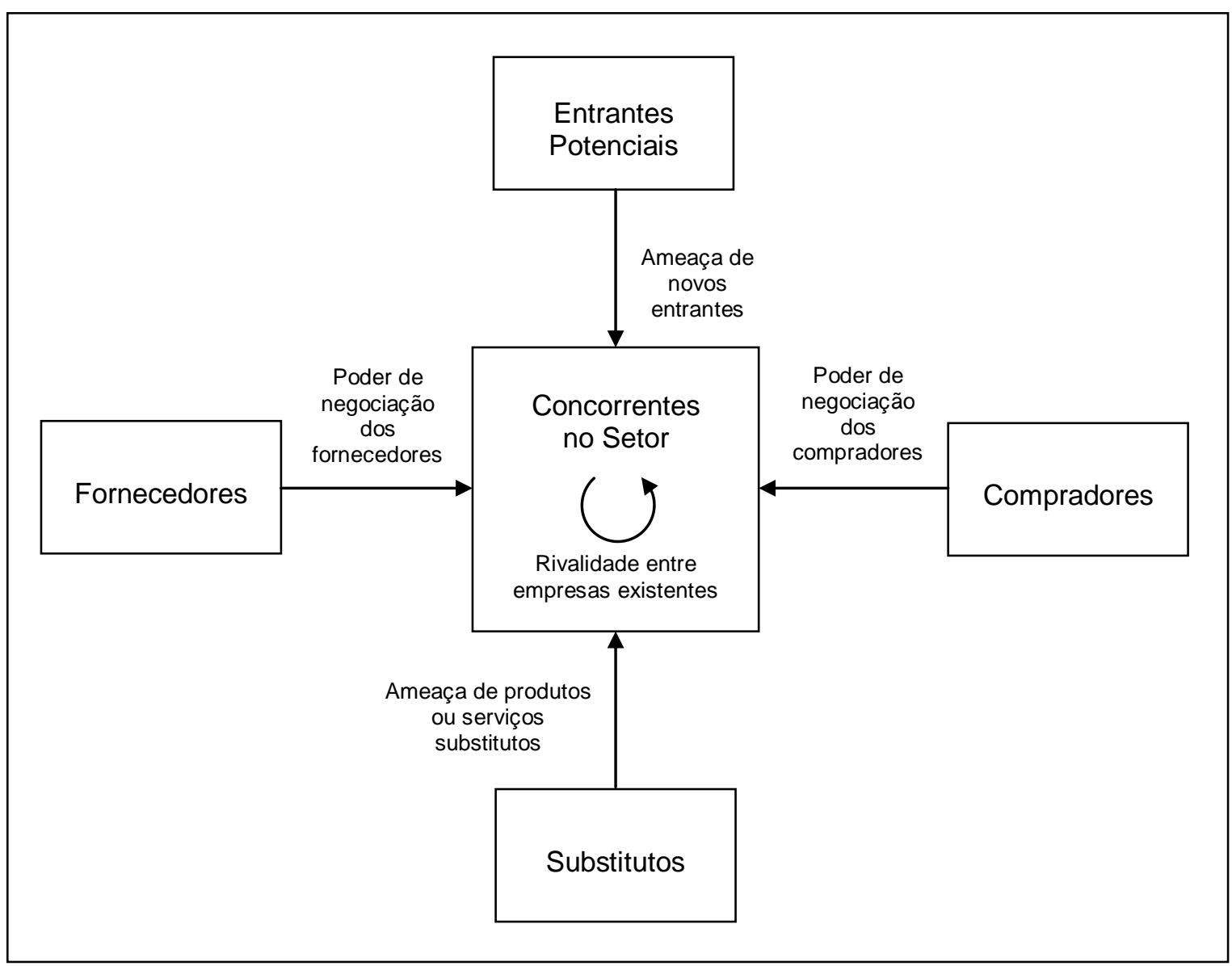

Figura 2.1 - Forças que dirigem a concorrência em um Setor Industrial (Porter, 2004)

O conjunto dessas forças determina o potencial de lucro final de um setor industrial, medido em termos de retorno a longo prazo sobre o capital investido. Nem todos os setores possuem o mesmo potencial, pois diferem à medida que o conjunto de forças varia. A meta da estratégia competitiva para uma empresa em um setor industrial é encontrar uma posição dentro dele em que a empresa possa melhor se defender contra essas forças competitivas ou influenciá-las a seu favor. A chave para o desenvolvimento de uma estratégia é pesquisar em maior profundidade e analisar as fontes de cada força. O conhecimento destas fontes põe em destaque os pontos fortes e os pontos fracos da empresa, esclarecendo pontos em que são necessárias mudanças para se obter um melhor retorno.

A seguir, será apresentada uma breve descrição da evolução do setor de semicondutores, setor onde atua a empresa em estudo. 


\subsubsection{O Setor de Semicondutores}

O setor de semicondutores teve seu desenvolvimento ligado aos setores de computação e de software, formando junto com estes o setor de microeletrônica. A cadeia produtiva de semicondutores é composta por três etapas principais: (1) a etapa de projeto, também chamada de design, (2) a etapa de fabricação (foundry) e (3) a etapa de empacotamento e testes (back-end). A Figura 2.2 representa as três etapas principais de produção de semicondutores.

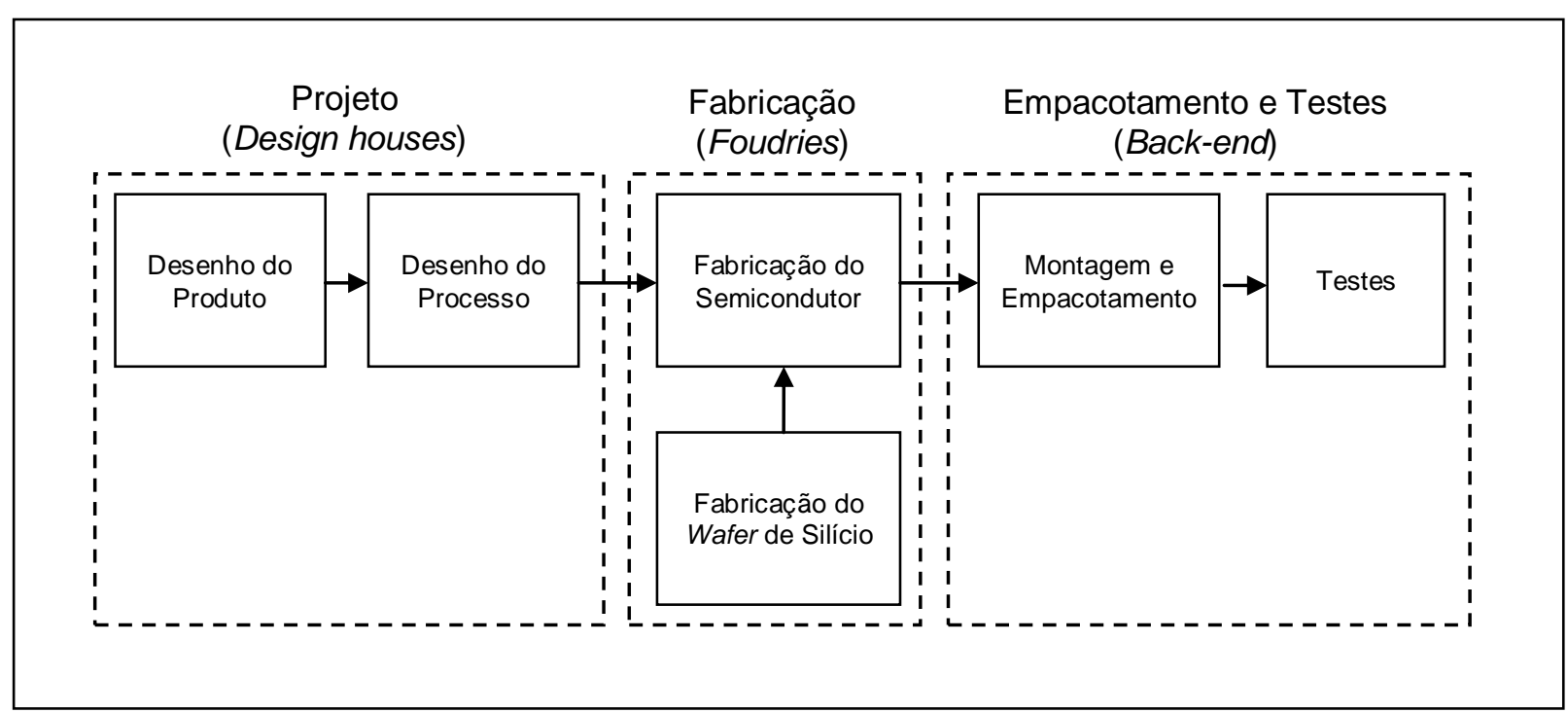

Figura 2.2 - Cadeia Produtiva de Semicondutores

Fontes: adaptada de Amato et al (2002)

A indústria global de semicondutores é bastante diversa, incluindo players de grande porte e players de pequeno e médio porte, sendo que estes últimos podem ser competitivos em nichos específicos.

Há empresas verticalmente integradas, abrangendo desde a produção de semicondutores até produtos eletrônicos finais. Estas empresas são caracterizadas por serem grandes conglomerados, com produção de semicondutores focada em sua demanda interna de produtos eletrônicos. A marca do produto final destas empresas é um elemento diferenciador, alavancando economias de escala. Estes conglomerados tendem a terceirizar as fábricas de semicondutores, estabelecendo contratos de manufatura (Contract Manufacturing), têm produção fortemente 
localizada na Ásia e montagem de bens finais espalhada pelo mundo, inclusive no Brasil.

Existem também empresas especializadas exclusivamente na produção de semicondutores, incluindo organizações de diversos tamanhos, com foco na fabricação de commodities em grande escala. Com poucas exceções, estas empresas dão pouca importância para a marca de seus produtos.

As empresas de semicondutores podem ser dedicadas a todas as três etapas do processo de fabricação ou a parte dele - projeto, fabricação e/ou empacotamento e testes -, atuando em determinados nichos de mercado. Geralmente são de pequeno ou médio porte, atendendo a necessidades específicas do usuário com pequena escala de produção.

O setor de microeletrônica, representado pelos setores de semicondutores, da computação e de software, nasceu no período pós Segunda Guerra Mundial (MOWERY e NELSON, 1999). As empresas norte-americanas logo passaram a dominar os três setores. Na década de 1980, porém, empresas japonesas tornaramse fortes competidores no setor de semicondutores. A partir do fim da década de 1980, entretanto, as empresas japonesas foram sendo desafiadas por empresas sulcoreanas, enquanto as empresas norte-americanas exploraram inovações nesses produtos e restabeleceram o domínio mundial sobre o setor de semicondutores. Enquanto as empresas japonesas e taiwanesas de computadores também desenvolveram considerável força em determinados nichos, como laptops e componentes de computadores, as empresas norte-americanas, entretanto, mantiveram posição de domínio na maioria dos tipos de computadores. A história do setor de software, por sua vez, tem sido dominada mundialmente por empresas norte-americanas desde seus primórdios até os dias atuais.

O declínio da participação no mercado mundial de semicondutores por empresas norte-americanas em meados da década de 1980 sugeria que o domínio norte-americano estava com seus dias contados. A perda de liderança norteamericana poderia representar o primeiro passo em uma sequência de quedas dos setores de sistemas eletrônicos. Olhando do ponto de vista externo ao norteamericano, os competidores poderiam estar se questionando: Como poderia um país ter sucesso em seus setores de sistemas eletrônicos sem desenvolver um setor de semicondutores próprio sólido? Este questionamento gerou um grande volume de 
trabalhos na literatura, apresentando como tema principalmente a competição entre Estados Unidos e Japão. Vários especialistas (FERGUSON, 1988; FLORIDA e KENNEY, 1990; FALLOWS, 1994) argumentavam que o sucesso japonês era reflexo de superioridades inerentes da estrutura do setor e de políticas estatais, em outros termos, pela superposição de estruturas de capitalismo empreendedor com formas de planejamento do sistema industrial. Enquanto isso, a indústria norte-americana de semicondutores e seus fornecedores domésticos apresentavam-se fragmentados e verticalmente desintegrados, devendo, segundo esses autores, seguir o exemplo da indústria japonesa. Esta visão foi traduzida na "MIT Commission on Industrial Productivity", que declarava em 1989 que as tradicionais estruturas e instituições norte-americanas se mostravam inapropriadas para fazer frente à forte competição japonesa. O setor de semicondutores norte-americano mostrava-se fragmentado e era chamado à consolidação. A resposta da indústria norte-americana não tardou a surgir, sendo uma combinação de vários fatores, entre eles: ênfase renovada na manufatura e na melhoria de produtividade, inovação e especialização organizacional e impulso favorável na importância dos produtos em que as empresas norte-americanas haviam se especializado.

A análise da evolução do setor de semicondutores tem sido o foco de atenção de vários pesquisadores (DIBIAGGIO, 2007; KAPOOR e ADNER, 2007; CLENDENIN, 2007; MALERBA et al, 2008b; LI, HUANG e CHEN, 2010). Vários fatores impactam no crescimento das vendas deste setor, como a emergência de novos usos para os equipamentos eletrônicos, o crescimento do consumo de produtos de informática e de telecomunicações, o nível de capacidade instalada, os níveis de estoques intermediários e os níveis de preços.

Ao analisar a evolução do setor de semicondutores no mundo, podem ser observados três aspectos que contribuem para seu desenvolvimento: a importância da demanda dos usuários finais, os efeitos das estratégias e da estrutura do setor e o papel das políticas governamentais.

Os padrões de demanda de usuários finais de semicondutores sempre tiveram caráter diferente, conforme a região. As empresas norte-americanas foram beneficiadas pela demanda militar da segunda guerra, em que o desempenho importava mais que o preço (LEVIN, 1982). Esta demanda impulsionou inovações na tecnologia do silício, que se mostrou também largamente aplicável em mercados 
não-militares e proporcionou às empresas americanas a vantagem do pioneirismo. À medida que a demanda militar diminuía, a indústria da computação apresentou-se como uma demanda alternativa que propiciou às empresas norte-americanas de semicondutores especializarem-se em dispositivos digitais e posteriormente em circuitos integrados (ICs). O desafio das indústrias de semicondutores japonesas também foi devido, em grande parte, pela demanda dos produtores japoneses. As vantagens dos CMOS (complementary metal-oxide semiconductor) em aplicações comerciais - incluindo, inicialmente, calculadoras eletrônicas - deu às empresas japonesas experiência crítica no que se provou ser a tecnologia dominante para propósito geral. Ao mesmo tempo, a demanda por chips de memória - e por chips de alta qualidade em geral - impulsionou as empresas japonesas a focarem na estratégia de especialização em DRAMs (dynamic random-access memory), abastecida pelas vantagens da produção em massa. Mais recentemente, as empresas norte-americanas se beneficiaram da especialização em chips de design intensivo, no momento em que a indústria de micro-computadores pessoais estava se desenvolvendo. Ainda analisando o impacto da demanda dos usuários finais, as empresas européias obtiveram melhores resultados quando focaram em origens internas de demanda, ao invés de tentarem competir com as empresas norteamericanas ou japonesas.

Além da demanda dos usuários finais, outro aspecto que influenciou a evolução do setor de semicondutores consistiu nos efeitos das estratégias e da estrutura do setor. Desde o surgimento da indústria de semicondutores, os Estados Unidos apresentavam seu setor industrial geral mais estruturado do que Japão ou Europa. Esta estrutura se desenvolveu movida pelo ambiente de propriedade intelectual presente à época da invenção do transistor e do circuito integrado e pelo caráter direcionado à inovação da demanda inicialmente militar e depois da indústria da computação. Uma estrutura industrial inicialmente descentralizada foi suficiente para as empresas norte-americanas manterem sua liderança. Mas assim que o setor foi adquirindo maturidade, a estrutura fragmentada tornou-se vulnerável diante do ataque de empresas japonesas especializadas na produção em massa de dispositivos eletrônicos. A estrutura industrial japonesa apresentava-se mais vertical e horizontalmente integrada, proporcionando às empresas japonesas vantagens de mercados de capital interno e competências corporativas. Ao perderem vantagem 
para os japoneses, as empresas norte-americanas foram obrigadas a retomarem 0 foco e a especialização, respondendo bem tanto em termos de inovação tecnológica como organizacional (SAXENIAN, 1994).

O terceiro aspecto que influenciou a evolução do setor de semicondutores foram as políticas governamentais. Analisando a história do setor de semicondutores, Mowery e Nelson (1999) observaram que o envolvimento do governo teve papel fundamental na evolução deste setor. As empresas norteamericanas, em seus primórdios, beneficiaram-se consideravelmente com o papel desempenhado pelas forças armadas, que além de impulsionar a demanda, tiveram papel como financiadora de pesquisa e desenvolvimento. No final da década de 1970, foi criada a Associação da Indústria de Semicondutores (SIA), que beneficiou o setor ao conseguir aprovar uma série de incentivos, como a eliminação de taxas e obtenção de proteção à produção de chips norte-americanos (YOFFIE, 1988). As empresas japonesas, por sua vez, foram beneficiadas pelos subsídios em pesquisa e desenvolvimento do programa VLSI (very-large-scale integration), criado com o propósito de aprofundar as competências japonesas a um nível tal que pudessem desafiar o domínio norte-americano, mas também tiveram sua produção impulsionada pela demanda da empresa japonesa NTT como compradora de semicondutores. Pode-se citar, também, a indústria de semicondutores de Taiwan, que se desenvolveu com apoio governamental, mesmo em um modelo de empresas desintegradas. Entre as atividades do governo taiwanês, podem ser citadas a criação de diversos institutos de pesquisa para desenvolvimento de tecnologia de ponta, investimentos em capital nas indústrias e incentivos para atrair talentos - por exemplo: engenheiros que fossem trabalhar na indústria de semicondutores estavam dispensados do serviço militar. No caso da Coreia do Sul, a indústria de semicondutores teve seu desenvolvimento acelerado entre 1974 e 1990 através de incentivos significativos do governo. Entre as ações governamentais sul-coreanas para a industrialização, podem ser citados planos quinquenais, escolha de áreas estratégicas, planos de financiamento, investimento pesado em conhecimento técnico e crescimento real dos salários. Pode-se observar que o comprometimento e apoio do governo é comum em vários países, conforme é apresentado no quadro comparativo dos incentivos governamentais para a indústria de componentes de microeletrônica (Quadro 2.1): 
Quadro 2.1 - Comparativo dos Incentivos Governamentais para a Indústria de Componentes de Microeletrônica

\begin{tabular}{|c|c|c|c|c|c|c|c|}
\hline Incentivos & EUA & $\begin{array}{l}\text { Reino } \\
\text { Unido }\end{array}$ & Alemanha & Coreia & Cingapura & Malásia & Filipinas \\
\hline Créditos, isenções & $\checkmark$ & $\checkmark$ & $\checkmark$ & $\checkmark$ & $\checkmark$ & $\checkmark$ & $\checkmark$ \\
\hline Abatimentos de impostos prediais & $\checkmark$ & $\checkmark$ & & $\checkmark$ & & & \\
\hline Empréstimos e garantias & $\checkmark$ & & $\checkmark$ & $\checkmark$ & $\checkmark$ & & \\
\hline Juros subsidiados & & & $\checkmark$ & & $\checkmark$ & & \\
\hline Investimentos em ações & & & $\checkmark$ & & $\checkmark$ & $\checkmark$ & \\
\hline Doações em dinheiro & & $\checkmark$ & $\checkmark$ & & $\checkmark$ & & $\checkmark$ \\
\hline Outros tipos de doações & & $\checkmark$ & $\checkmark$ & $\checkmark$ & $\checkmark$ & $\checkmark$ & \\
\hline $\begin{array}{l}\text { Dispensa de exigências } \\
\text { regulatórias }\end{array}$ & & $\checkmark$ & $\checkmark$ & & & & \\
\hline Apoio financeiro à tecnologia & & $\checkmark$ & $\checkmark$ & $\checkmark$ & $\checkmark$ & $\checkmark$ & $\checkmark$ \\
\hline Apoio financeiro a treinamento & & $\checkmark$ & $\checkmark$ & $\checkmark$ & $\checkmark$ & $\checkmark$ & $\checkmark$ \\
\hline
\end{tabular}

Fonte: (AMATO et al, 2002)

Os fortes incentivos governamentais atraíram fabricantes de semicondutores para diversos países do mundo, como pode ser observado nos exemplos a seguir:

- Índia:

- Fundo Governamental de Custeio: até 30\% de subsídio em investimentos até US\$ 3 milhões;

- Investimento de Capital: até 10\% até US\$ 1 milhão;

- Imposto sobre venda: isenção total por até 5 anos;

- Imposto sobre importação: isenção para máquinas e equipamentos para novas instalações.

- Israel:

- Fundo Governamental de Custeio: cobertura de 30 a $60 \%$ dos projetos de P\&D;

- Participação do governo nos riscos: 2/3 de todos os investimentos (a fundo perdido);

- Doação para P\&D subcontratada: 20\%;

- Doação governamental: investimento em ativo fixo até 38\%;

- Isenção de taxas e impostos: por período de 10 anos;

- Pequenos negócios com menos de 75 funcionários: doação de US\$250 mil a fundo perdido. 
- Alemanha:

- Fundo Governamental de Custeio: forte apoio do governo - maiores incentivos da Europa;

- Empréstimo: 35\% para grandes e 50\% para pequenas empresas;

- Treinamento: totalmente por conta do governo;

- Imposto de renda: redução de $45 \%$ para $35 \%$ para lucro retido e de $35 \%$ para $25 \%$ para lucro distribuído;

- Perdas: transferidas e deduzidas sem tempo limite;

- Subsídios diretos: governo empresta a taxas menores que as do mercado;

- Contratação Inicial: governo assume responsabilidade da seleção inicial.

- China e Hong Kong:

- 20 anos de isenção de impostos para instalação de uma fábrica nesses países.

No Brasil, as condições de desenvolvimento da indústria brasileira de semicondutores foram analisadas por Amato et al (2002), discutindo oportunidades e desafios existentes para o setor. $O$ peso relativo de semicondutores nos produtos finais brasileiros é significativo, principalmente em informática e telecomunicações. Os semicondutores brasileiros representavam, no início da década de 2000, menos de $5 \%$ do consumo total, havendo apenas quatro fabricantes locais e nenhuma fábrica de circuitos integrados. O mercado brasileiro, portanto, tem sido abastecido por fornecedores externos, tanto em semicondutores, como em placas montadas e produto final.

O setor de informática é o maior consumidor do setor de semicondutores, impactando no crescimento deste último. No mercado brasileiro, a venda de PC's teve um significativo crescimento desde o ano 2000 e tende a continuar a crescer nos próximos anos, devido a vários fatores:

- A penetração dos PC's em residências no Brasil ainda é relativamente baixa, na faixa dos $35 \%$, sendo que o mercado residencial representa cerca de $40 \%$ das vendas (CGI.br, 2010);

- Impulso ao crescimento do mercado devido aos computadores de baixo preço, voltados principalmente ao acesso à internet; 
- Os fabricantes estão buscando reforçar suas estratégias para atender a esse segmento consumidor e combater o mercado informal (que chegava a atingir $50 \%$ do mercado total no ano 2000), por meio do reforço dos sistemas de distribuição e de suporte, aumento da penetração fora dos grandes centros urbanos e lançamento de linhas de produtos mais populares.

O setor de semicondutores também foi alavancado e deve continuar crescendo devido à entrada de produtos digitais, como DVDs e TV digital, e pela conectividade entre PC's e produtos eletrônicos, como a introdução de softwares que permitem manipular dados digitais a partir de diversas fontes, como filmadoras, audio players e câmeras digitais, e adoção da tecnologia USB para conectar PC's e diversos produtos de eletrônica de consumo. Além disso, o segmento de smart cards apresentou crescimento devido ao uso em telefones móveis SIM e pela maior utilização pelos bancos na migração dos cartões magnéticos para smart cards. Cada vez mais, os semicondutores farão parte do cotidiano das pessoas e estarão presentes nos mais diversos mercados, podendo-se citar como exemplos: automação do lar - já uma realidade em países desenvolvidos, visando conforto e comodidade, segurança e gestão de instalações; automação industrial; agropecuária - por exemplo: identificação de gado; identificação de animais de estimação - por exemplo: identificação de cachorros por meio de chips; equipamentos médicohospitalares; brinquedos eletrônicos.

No Brasil estavam instalados apenas os elos finais das cadeias produtivas que utilizam os semicondutores. Para reverter este quadro, era preciso preencher as lacunas existentes nesta cadeia: design houses, foundry e backend. Laurindo e Carvalho (2003), ao investigarem o impacto de aspectos como outsourcing, inovação, valor e evolução da indústria de computadores pessoais (PCs) na competitividade da indústria de PCs do Brasil, também apontam para a ausência de competências locais nos elos a montante da cadeia produtiva, aspecto que causa a dependência de fornecedores estrangeiros com maior poder de barganha, uma vez que estes últimos produzem itens que representam grande parte dos custos de produção. De acordo com estes autores, portanto, a indústria brasileira de PCs apresentava, na época do estudo, lacunas nos elos destacados como de maior valor agregado. 
O Quadro 2.2 apresenta os principais players do setor no Brasil:

\begin{tabular}{|c|c|c|}
\hline Etapa do Processo & Empresa & Estado \\
\hline \multirow{20}{*}{ Design Houses } & CT PIM & AM \\
\hline & C.E.S.A.R & PE \\
\hline & CETENE & $\mathrm{PE}$ \\
\hline & SiliconReef & $\mathrm{PE}$ \\
\hline & TE@I2 & $\mathrm{PE}$ \\
\hline & DF Chip & DF \\
\hline & MINAS IT & MG \\
\hline & $\mathrm{DHBH}$ & MG \\
\hline & LSI-TEC & SP \\
\hline & EXCELCHIP & SP \\
\hline & ELDORADO & SP \\
\hline & $\mathrm{CTI}$ & SP \\
\hline & FREESCALE & SP \\
\hline & IDEA! & $\mathrm{SP}$ \\
\hline & Centro Werner von Braun & SP \\
\hline & NPCI COPPE & RJ \\
\hline & $\mathrm{FDH}$ & SC \\
\hline & CHIPUS & SC \\
\hline & CEITEC & RS \\
\hline & PORTOCHIP & $\mathrm{RS}$ \\
\hline \multirow{7}{*}{ Foudries } & CEITEC & RS \\
\hline & HT Micron & RS \\
\hline & Nanium & MG \\
\hline & SiliconReef & $\mathrm{PE}$ \\
\hline & Smart & SP \\
\hline & Flex IC & $\mathrm{SP}$ \\
\hline & CBS & MG \\
\hline Back-end & Smart & SP \\
\hline
\end{tabular}

Fontes: ApexBrasil (2012), MDIC (2012), MCTI (2012)

Neste contexto, com o propósito de desenvolver o setor de microeletrônica no Brasil, o governo federal, por meio do Ministério da Ciência, Tecnologia e Inovação, investiu na criação de uma empresa de semicondutores. Considerando o papel fundamental que as políticas governamentais tiveram na evolução do setor em diversos países, esta iniciativa do governo brasileiro mostra-se como positiva, constituindo um embrião para o desenvolvimento do setor no Brasil. No entanto, ao criar uma empresa "por decreto", surge ao mesmo tempo o desafio de criar uma estrutura para que esta empresa passe a operar e seja produtiva. Em outras palavras, é necessário definir seu desenho organizacional, conceito que será apresentado a seguir. 


\subsection{Desenho Organizacional}

O desenho organizacional é composto pela estrutura para a execução da estratégia da organização. Segundo Galbraith (1994), o conceito de desenho organizacional resulta da combinação da definição de organização com o conceito de opção estratégica. Uma organização é composta por pessoas e grupos de pessoas para atingir um objetivo comum, através da divisão do trabalho, integrado por processos de decisão baseados em informação, continuamente ao longo do tempo. O desenho organizacional é concebido como um processo de decisão que proporcione coerência entre as metas e propósitos para os quais a organização existe, os padrões de divisão e coordenação do trabalho e as pessoas que irão trabalhar. A noção de opção estratégica sugere que existem opções de metas e propósitos, opções de modos de organização, opções de processos para integração dos indivíduos na organização e, finalmente, opções de como metas, modos de organização, indivíduos ou alguma combinação entre eles devem ser mudados para se adaptar às mudanças do ambiente.

O modelo de desenho organizacional proposto por Galbraith, conhecido como "modelo da estrela", tem sido refinado e utilizado por mais de 30 anos (GALBRAITH, 1977; GALBRAITH, 1994; KATES e GALBRAITH, 2007). A última versão do modelo proposto por Galbraith (2009), esquematizada na Figura 2.3, apresenta os elementos do desenho organizacional, ou seja, as principais dimensões nas quais uma organização deve fazer opções para atingir seus objetivos: 


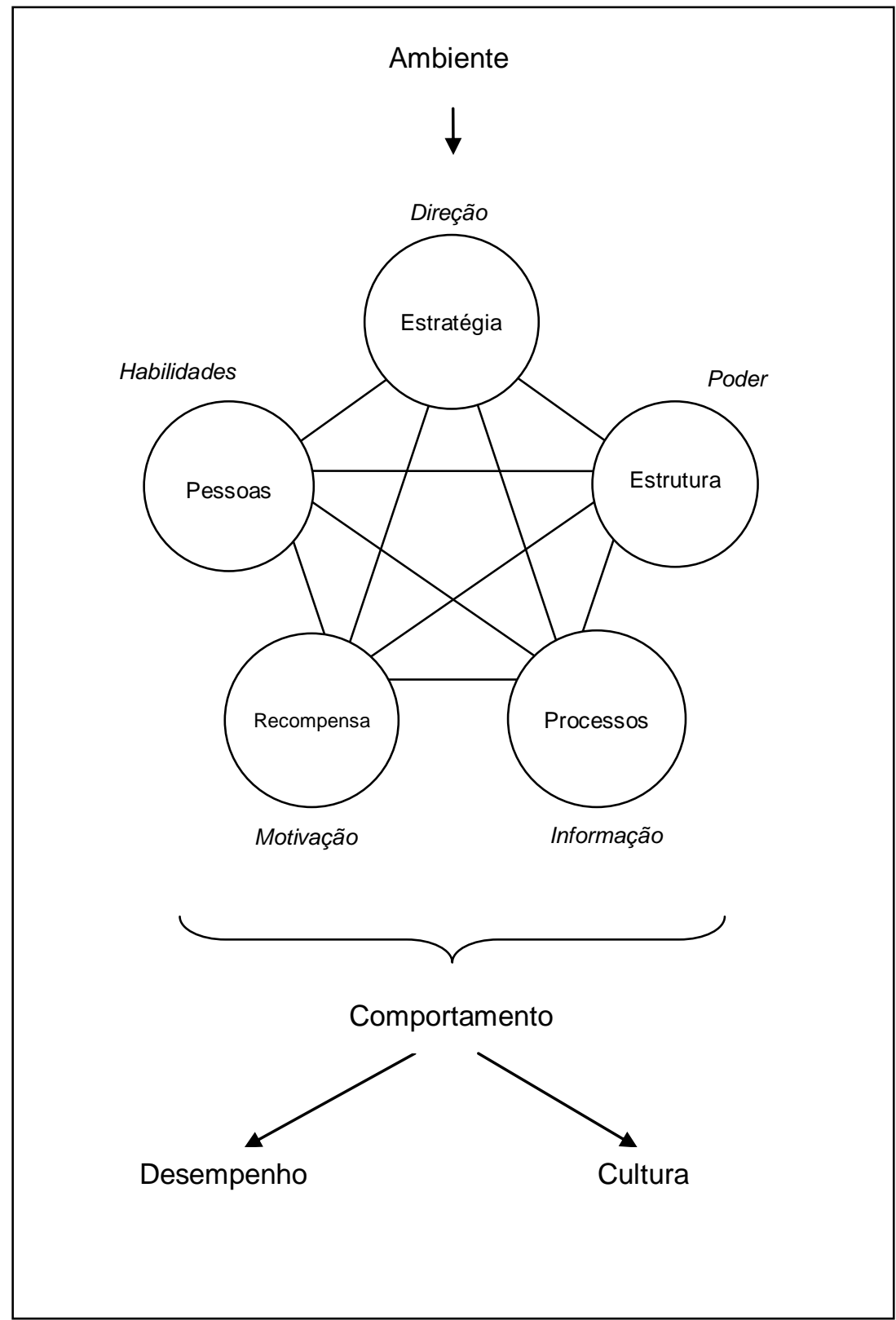

Figura 2.3 - Desenho Organizacional (Modelo da "Estrela") - adaptado de Galbraith (2009)

- Estratégia - pode ser definida como a fórmula para alcançar o sucesso de uma organização. A estratégia dá a direção da empresa, especificando as metas e os objetivos a serem atingidos, assim como os valores e a missão perseguidos pela organização;

- Pessoas - nesta dimensão pode-se analisar variáveis como competências, habilidades, estilo de liderança, treinamento e desenvolvimento, transferência e seleção de pessoal, clima organizacional, entre outras; 
- Sistemas de Recompensa - esta dimensão pode apresentar como variáveis a motivação, o sistema de compensação, a base de promoção e planos de carreira, que apresentam impacto na satisfação do pessoal;

- Processos - sequência de atividades necessária para a obtenção de bens e serviços. Esta dimensão inclui a distribuição da informação por todos os envolvidos nos processos, o uso de tecnologia de informação adequada e o fornecimento de dados precisos (e relevantes) para os responsáveis dos processos. Nesta dimensão podem ser analisadas variáveis como diversidade, dificuldade e variabilidade de processos e subprocessos, formalização de processos, desempenho de processos, sistemas de informação, frequência de coleta de dados e escopo da base de dados;

- Estrutura - modo de organização do trabalho, geralmente expresso na forma de organogramas. Pode-se optar por diferentes modos de divisão do trabalho, departamentalização, configuração e distribuição de poder (grau de autonomia).

O desenho organizacional tem impacto direto no comportamento da organização, e por consequência, em seus resultados (desempenho). Uma organização com dimensões de seu desenho organizacional bem definidas e alinhadas entre si e com o ambiente terá mais chances de apresentar um bom desempenho.

Todas as dimensões do desenho organizacional são em algum grau variáveis e controláveis pelos tomadores de decisão de uma organização e devem estar alinhadas entre si. Para executar a estratégia, os gestores de uma organização devem tomar decisões, baseadas em seus objetivos e valores, sobre vários aspectos, tais como os processos que as pessoas devem executar, a estrutura de trabalho (organograma) em que devem atuar, como elas serão recompensadas, como devem tomar decisões, que informações devem utilizar ou até mesmo sobre suas habilidades e motivações. Todos estes elementos são inter-relacionados (conforme a Figura 2.3). Por isso, qualquer mudança em algum destes elementos provavelmente irá produzir alterações nos demais. A escolha de qual variável mudar depende da opção estratégica da organização, sendo que a manutenção da coerência entre as diversas dimensões do desenho organizacional é ponto crítico 
para o sucesso da organização. As opções dos elementos do desenho organizacional tendem a reforçar padrões de comportamento dentro da organização, causando impacto na cultura organizacional, e vice-versa.

Nadler et al (1994) também dedicaram seus trabalhos ao tema projeto (desenho) organizacional. Segundo estes autores, a função primordial da alta gerência é projetar, construir e operar organizações que funcionem eficientemente. Estes autores escolheram o nome "Arquitetura Organizacional" para definir a ampla série de decisões que os administradores devem tomar, incluindo a configuração e a dinâmica pela qual os vários elementos de organização se combinam para criar uma empresa produtiva. Os administradores devem considerar duas séries de questões ao projetar uma empresa. Devem pensar, de um lado, em como a arquitetura permitirá à organização executar suas várias estratégias e realizar o trabalho exigido; de outro lado, devem considerar como a arquitetura se harmonizará com os indivíduos que trabalham na organização, ou sobre os quais a organização terá algum tipo de impacto. Nadler et al (1994) argumentam que a visão clássica da estrutura de uma organização, representada por um organograma, é muito limitada e estática, uma vez que exclui o comportamento de liderança, o impacto do ambiente, as relações informais e a distribuição de poder. Uma alternativa viável para essa visão clássica e estática consiste em entender a organização como um sistema social, inspirada na teoria dos sistemas abertos. Algumas características de sistemas são evidenciadas nas organizações:

- Interdependência interna - mudanças em um componente da organização apresentam, frequentemente, repercussão sobre outros componentes;

- Capacidade de feedback - as informações sobre o(s) produto(s) podem ser utilizadas para controlar o sistema;

- Equilíbrio - quando um evento perturba o equilíbrio do sistema, este reage voltando ao equilíbrio;

- Equifinalidade - diferentes configurações de sistemas podem levar ao mesmo fim ou ao mesmo tipo de conversão insumo/produto;

- Adaptação - para que um sistema sobreviva, deve manter um equilíbrio favorável das transações de insumo e produto com o ambiente, ou declinará. 
Nadler et al (1994) identificam quatro componentes principais das organizações: trabalho, pessoal, organização formal e organização informal.

- Trabalho - é a atividade básica a que a organização se dedica, visando executar sua estratégia. São enfatizadas as atividades de trabalho específicas que precisam ser realizadas e suas características inerentes, incluindo a descrição do trabalho básico e dos fluxos de trabalho (processos);

- Pessoal - são as pessoas que realizam as tarefas. Devem ser identificadas as características dos colaboradores, incluindo a natureza do conhecimento e habilidades individuais, as diferentes necessidades ou preferências dos indivíduos e suas percepções ou expectativas;

- Organização formal - são as estruturas e procedimentos explícitos e formalmente desenvolvidos, de modo que os colaboradores realizem tarefas consistentes com a estratégia da organização;

- Organização informal - são disposições implícitas ou tácitas, que podem exercer considerável influência sobre o comportamento, sendo muitas vezes descritas como cultura organizacional.

Segundo Nadler et al (1994), a organização pode, portanto, ser considerada como uma série de componentes - trabalho, pessoas, organização formal e organização informal. A questão crítica, porém, em qualquer sistema, não é apenas a identificação dos componentes, mas a natureza das interações e a maneira pela qual as relações entre os componentes afetam o desempenho do sistema.

Waterman (1989) argumenta que as empresas podem ser imaginadas como sendo conjuntos de aptidões, capacidades e competências. Este autor propõe a estrutura dos 7-S (Skills, Structure, Strategy, Systems, Symbolic Behavior, Shared Values e Staff), cujos elementos são descritos a seguir:

- Aptidões (Skills) - variável dependente localizada no centro da estrutura dos 7-S. A ideia é que a organização como um todo estará apta em algo até o grau em que os outros seis elementos da estrutura (descritos a seguir) apoiarem essa aptidão; 
- Estrutura (Structure) - organograma, descrições de cargos e assemelhados. Formas de mostrar quem se reporta a quem e como as tarefas são divididas e integradas;

- Estratégia (Strategy) - definida de modo restrito, é o plano da empresa para alocar recursos e conseguir uma vantagem competitiva sustentável;

- Sistemas (Systems) - processos e fluxos, formais e informais, que há na organização, incluindo sistemas de fabricação, contabilização, controle de qualidade, medição de desempenho, etc.;

- Comportamento Simbólico (Symbolic Behavior) - também chamado de estilo, é a evidência daquilo que a gerência considera importante, especialmente como é descrito por comunicação não verbal. É o modo pelo qual os gerentes usam seu tempo, os resultados que eles premiam e a maneira como agem em crises;

- Valores Compartilhados (Shared Values) - aquilo que a empresa defende, declarado ou implícito, aquilo de que a empresa se orgulha ou do que gostaria de se orgulhar;

- Staff - as pessoas em uma organização, suas características demográficas, sua experiência, educação e treinamento. Envolve o alinhamento entre os trabalhos que devem ser executados e as aptidões das pessoas que irão executá-los.

Um aspecto importante a ser verificado no desenho organizacional é a questão temporal, uma vez que as decisões sobre as dimensões componentes do desenho de uma organização devem evoluir ao longo do tempo, à medida que os objetivos a serem atingidos se modificam ou o ambiente se altera. A integração temporal dentro de um sistema produtivo foi abordada por Muscat (1993). Todas as vezes em que se fala de decisão, qualquer que seja ela, deve-se considerar, concomitantemente, o elemento tempo. O motivo é simples: decisões são tomadas para que algo, no futuro, possa ocorrer. Assim, decisões de plano de produção, de um novo arranjo físico, de um método de trabalho aperfeiçoado ou mesmo de todo o desenho organizacional, sempre se referem a um período futuro, em que a decisão estará implantada e em operação. Em se referindo ao futuro, a decisão deverá estar 
baseada em informações referentes a esse futuro. São três as categorias básicas de informação que uma função de decisão deve receber para gerar a decisão:

- Informações referentes ao ambiente;

- Informações provenientes de outras funções de decisão;

- Informações referentes ao sistema físico.

Devido a alterações no ambiente e no sistema físico de produção, as funções de decisão devem sofrer modificações com o tempo. Uma integração temporal ideal significa uma função de decisão com uma trajetória temporal adequada às necessidades de modificação do sistema de gestão face ao ambiente e ao sistema físico. Se a trajetória não for adequada, não haverá a integração temporal ideal, e a função de decisão não estará permitindo obter o melhor resultado possível para o sistema de produção. É interessante frisar que o conceito de integração temporal está ligado a uma trajetória e não a uma única posição no tempo.

A seguir, será estudada em detalhe cada uma das dimensões do desenho organizacional - Estratégia, Pessoas, Sistemas de Recompensa, Processos e Estrutura -, lembrando que todas as dimensões são inter-relacionadas e dependentes entre si dentro de uma organização.

\subsubsection{Dimensão Estratégia}

Uma vez conhecidas as características do ambiente de atuação da organização, esta tem subsídios para definir sua estratégia organizacional. O conceito de estratégia organizacional abrange várias abordagens e está em contínua evolução (CARVALHO e LAURINDO, 2003). As várias formas de entender o conceito de estratégia podem variar entre as escolas de formulação da estratégia, com pensamento de caráter analítico e prescritivo, que visam instruir, e as de caráter descritivo, que buscam inspirar ao invés de instruir. Além das escolas voltadas para a formulação, há abordagens que estão ganhando evidência e focam a implementação da estratégia. Para Eisenhardt (1989), definindo de uma forma simples, a estratégia deve responder duas questões: aonde se pretende chegar e como chegar lá. 
Uma vez formulada a estratégia, passa-se para o processo de implementação da mesma e, a seguir, mensuração e monitoramento dos resultados obtidos. No entanto, o processo de formulação e implementação da estratégia costuma ser lento, sendo realizado muitas vezes de forma isolada pela alta administração. Deve-se notar, porém, que não se pode dissociar o planejamento estratégico das ações, o que exige o comprometimento de todos na organização, não apenas da alta diretoria. As ações de todos devem estar alinhadas com a estratégia formulada para que a implementação seja efetiva.

Uma das formas de definir e implementar a estratégia consiste na busca do alinhamento desta com perspectivas importantes, definidas pelo modelo do Balanced Scorecard (BSC), descrito a seguir.

\subsubsection{O Modelo do Balanced Scorecard}

O Balanced Scorecard é uma das abordagens disponíveis na literatura que trata do alinhamento estratégico e de seu desdobramento em metas, objetivos e requisitos organizacionais. A abordagem foi idealizada com o objetivo de complementar os sistemas tradicionais de medidas de desempenho baseados em indicadores financeiros (KAPLAN e NORTON, 1992), uma vez que esses indicadores não mais atendiam às necessidades de medição das habilidades, competências e outros ativos intangíveis buscados atualmente pelas organizações. Os ativos intangíveis, tais como o relacionamento com os clientes, a habilidade e o conhecimento da força de trabalho, a existência de uma cultura corporativa voltada para a inovação e melhoria, entre outros, não eram incluídos nas formas tradicionais de medição de desempenho, apesar de serem atualmente importantes fontes de vantagem competitiva. Enquanto buscava-se remediar a inadequação tentando melhorar os indicadores financeiros, outros trabalhos de pesquisa defendiam a utilização de indicadores operacionais, tais como tempo de ciclo ou taxa de falhas, uma vez que melhorando o desempenho operacional, a melhoria no resultado financeiro seria uma consequência.

Kaplan e Norton (1992), no entanto, afirmam que nenhum indicador sozinho pode, isoladamente, proporcionar uma clara visão do desempenho da organização. É necessário, portanto, apresentar medidas balanceadas, utilizando tanto 
indicadores financeiros quanto operacionais. Desta forma, os autores propuseram um modelo que chamaram de Balanced Scorecard, que consiste em um quadro de indicadores que permite à alta diretoria obter uma rápida, porém completa, visão do negócio. O modelo do BSC inclui medidas financeiras, que apresentam os resultados das ações já tomadas, sendo que estas são complementadas por indicadores operacionais sobre a satisfação dos clientes, os processos internos e as atividades de aprendizado e crescimento da organização. Estes indicadores operacionais são os direcionadores da futura performance financeira, uma vez que a complexidade de gerenciar uma organização atualmente exige que os gerentes possuam uma visão simultânea do desempenho em diversas áreas do negócio. Assim, o BSC permite obter uma visão a partir de quatro importantes perspectivas (KAPLAN e NORTON, 1996): Financeira, Cliente, Processos Internos e Aprendizado e Crescimento. Cada perspectiva apresenta seu próprio grupo de indicadores de desempenho, que refletem as necessidades de cada organização. A visão e a estratégia são traduzidas em termos do conhecimento, das habilidades, das tecnologias e da cultura organizacional (aprendizado e crescimento) para construir os meios eficientes e eficazes (processos internos) que podem entregar valor específico ao mercado (clientes), aumentando o valor ao acionista (financeiro).

$\mathrm{Na}$ verdade, o BSC não tem sido utilizado apenas como um sistema de indicadores, mas também como um novo sistema de gestão estratégica. O BSC apresenta quatro novos processos gerenciais que, combinados com as perspectivas, contribuem para alinhar os objetivos estratégicos de longo prazo com as ações de curto prazo. Os quatro novos processos são:

- Traduzindo a visão: auxilia a construir um consenso sobre a visão e a estratégia da organização. É comum, no entanto, que exista uma lacuna entre as declarações de missão e o conhecimento dos funcionários sobre as ações do dia a dia que contribuem para a realização da missão. Para que as ações ocorram de forma alinhada com a visão e a estratégia, estas declarações devem ser expressas de forma integrada com os objetivos e os indicadores organizacionais, com a concordância de todos, pois serão os direcionadores do sucesso da organização no longo prazo; 
- Comunicação e ligação: permite comunicar a estratégia do nível mais alto para o mais baixo, ligando-os aos objetivos departamentais e individuais. Neste ponto, é essencial que os indicadores estratégicos do BSC sejam desdobrados em indicadores em todos os níveis da organização, inclusive no nível operacional. O desenvolvimento de indicadores operacionais para as quatro perspectivas faz com que os gestores compreendam o real sentido da declaração estratégica;

- Planejamento do negócio: permite às empresas integrarem seus planos financeiro e de negócio. Criar um BSC faz com que a organização integre seu planejamento estratégico ao processo de orçamento, de forma a assegurar que o orçamento irá suportar as estratégias planejadas. Uma vez que a estratégia está definida e os direcionadores estão identificados, o BSC influencia os gestores a concentrarem sua atenção no aperfeiçoamento ou na reengenharia dos processos considerados críticos para o sucesso da estratégia organizacional. Esta é a forma mais clara de como a organização liga e alinha suas ações com a estratégia;

- Feedback e aprendizado: proporciona à organização a capacidade de aprendizado estratégico. Com o BSC no centro do sistema de gestão, as empresas podem monitorar os resultados de curto prazo a partir de três perspectivas adicionais, além da perspectiva financeira, avaliando a necessidade de modificar estratégias que reflitam o aprendizado organizacional.

Para facilitar a divulgação e a compreensão da estratégia por todos na organização, Kaplan e Norton (2000) sugerem a construção de um "mapa estratégico" - uma ferramenta para comunicar tanto a estratégia como os processos e sistemas de indicadores que irão auxiliar na implementação da mesma. O mapa mostra as relações de causa e efeito através das quais as melhorias criam os resultados desejados. O mapa estratégico apresenta quatro regiões distintas, correspondentes às quatro perspectivas do BSC: Financeira, Cliente, Processos Internos e Aprendizado e Crescimento. Dentro destas quatro perspectivas, o mapa apresenta os objetivos estratégicos (o que deve ser alcançado e o que é crítico para o sucesso de uma organização), os indicadores de desempenho (como será medido e acompanhado o sucesso do alcance do objetivo), as metas (o nível de desempenho ou a taxa de melhoria necessários) e os projetos ou iniciativas 
estratégicos (meios que ajudarão a organização a atingir os desafios estratégicos impostos pelas metas). A melhor forma de se construir um mapa estratégico é de cima para baixo, ou seja, iniciando pelo destino e a seguir representando as rotas que levam a ele. Inicialmente, deve-se desenvolver (ou revisar) a missão e os valores essenciais da organização e, com estas informações, pode-se desenvolver a visão organizacional. A estratégia deve então definir a lógica de como transformar esta visão em realidade. A aplicação do BSC vem sendo conduzida em organizações provenientes de diversos setores econômicos, principalmente na iniciativa privada. Há relatos de algumas aplicações do BSC no setor público, que são destacadas a seguir.

\subsubsection{BSC no Setor Público}

Na área pública, várias instituições têm estudado e implantado novas formas de gestão estratégica, uma vez que também neste setor o foco da otimização do uso de recursos tem sido uma necessidade preponderante. Kaplan e Norton (2004) relatam alguns casos de implantação do modelo do BSC e do uso de mapas estratégicos como forma de garantir a divulgação da estratégia de governo, bem como o foco do uso de recursos.

Existem relatos de casos de utilização da metodologia do BSC no setor público. Greasley (2004), por exemplo, descreve a aplicação da metodologia no departamento de polícia do Reino Unido, associada a um programa de aperfeiçoamento. O autor argumenta que a metodologia auxilia a conciliar os interesses dos diversos stakeholders envolvidos em organizações do setor público. Carmona e Grönlund (2003) descrevem um caso de utilização da metodologia do BSC na polícia sueca, relatando que, apesar da implementação ter apresentado resultados positivos, ocorreram problemas devido a vários fatores, entre eles a agregação de indicadores não financeiros, a omissão de medição de desempenho de algumas áreas e a definição de indicadores simplistas. Wilson, Hagarty e Gauthier (2003) relatam casos de utilização do BSC em instituições públicas do Canadá, Estados Unidos, Noruega e Suécia, e concluem que a abordagem do BSC 
tem sido bem aceita no setor público. Estes autores comentam que, para um sistema de medidas de desempenho ter sucesso, deve-se evitar o erro de criar indicadores em demasia, sob o risco de perder o foco sobre as informações realmente críticas. Radnor e Lovell (2003) analisam casos em agências do Serviço Nacional de Saúde do Reino Unido, levantando fatores de sucesso para a implementação do modelo do BSC. No setor público brasileiro, Muscat, Biazzi e Miguel (2007) descrevem um estudo de caso de formulação e implementação da estratégia em uma instituição pública brasileira do setor educacional, utilizando o modelo do BSC. Neste trabalho são analisados os objetivos estratégicos e os indicadores sugeridos. Os resultados da análise indicaram diferenças em relação à aplicação tradicional do BSC no setor privado, além de dificuldades de envolvimento dos funcionários, de desdobramento das estratégias e da medição dos indicadores sugeridos.

\subsubsection{Dimensão Pessoas}

Outra dimensão do desenho organizacional está relacionada à gestão de pessoas. Toda organização depende do desempenho humano para seu sucesso. A importância que o comportamento humano vem assumindo no âmbito dos negócios fez com que a preocupação com sua gestão alcançasse espaço cada vez maior (FISCHER, 2002). É nesse contexto que surge o conceito de modelo de gestão de pessoas. Entende-se por modelo de gestão de pessoas a forma como uma empresa se organiza para gerenciar e orientar o comportamento humano no trabalho. É composto por princípios, estratégias, políticas e práticas de gestão que orientam os gestores de uma empresa em relação aos que nela trabalham. O modelo de gestão de pessoas deve estar alinhado à estratégia da organização. A missão do gestor consiste, portanto, em identificar padrões de comportamento coerentes com 0 negócio da organização. Os modelos de gestão de pessoas são determinados por fatores internos ou externos à organização, ou seja, em diferentes contextos históricos ou setoriais são encontradas diferentes modalidades de gestão. Dentre os fatores internos, destacam-se o produto ou serviço oferecido, a tecnologia adotada, a forma de organização do trabalho, a cultura e a estrutura organizacional. Entre os fatores externos, a cultura de trabalho de cada sociedade, sua legislação trabalhista 
e o papel exercido pelo governo e pelos demais agentes nas relações de trabalho vão estabelecer os limites de atuação de cada modelo de gestão de pessoas. Somente com o entendimento adequado de todos os fatores condicionantes é que se torna possível determinar um modelo de gestão coerente com as necessidades da empresa. A seguir, são detalhados alguns fatores condicionantes do modelo de gestão de pessoas:

- Tecnologia adotada - o tipo de equipamentos ou máquinas utilizadas pelos funcionários influencia fortemente o comportamento dos funcionários. Operários de linha de produção, por exemplo, são forçados a trabalharem no ritmo e na velocidade da linha. Não se espera dos mesmos que tenham iniciativas ou autocontrole, basta que o cartão de ponto registre sua presença. Se o mesmo trabalho, porém, for automatizado, o funcionário não irá mais simplesmente executar a atividade, mas se tornará responsável por monitorar a atividade que o equipamento executa, podendo atuar em casos de irregularidade e ter autonomia para resolver problemas. No primeiro caso, o modelo de gestão pode limitar-se ao controle de presença do trabalhador; já no segundo caso, deve-se garantir que o funcionário compreenda e esteja envolvido com seu trabalho, de modo a estimular a iniciativa individual de cada trabalhador.

- Formas de Organização do Trabalho - as diferentes formas de organização do trabalho, como grupos semiautônomos, operadores multifuncionais ou células de trabalho, influenciam, assim como a tecnologia adotada, o comportamento dos funcionários enquanto executam o processo de trabalho.

- Cultura Organizacional - o conceito de cultura organizacional refere-se a um sistema de valores compartilhado pelos membros de uma organização, que a difere de outras organizações. A cultura pode ser entendida como o conjunto de crenças e valores, costumes, tradições, conhecimentos e práticas de convívio social e relacionamento entre as pessoas. A cultura organizacional interfere e, ao mesmo tempo, influencia o modelo de gestão de pessoas de uma organização.

- Estrutura Organizacional - a estrutura organizacional, usualmente visualizada na forma de um organograma, exerce forte influência sobre o modelo de gestão de pessoas. Uma estrutura departamental, explicitamente orientada 
para a cadeia de comando e controle, com vários níveis hierárquicos, implica em um modelo igualmente segmentado e restritivo. Uma estrutura matricial, por sua vez, demanda práticas de recursos humanos que percebam a empresa como um todo, com enfoque sistêmico da organização. A remuneração, por exemplo, pode não estar associada exclusivamente ao cargo, mas ao perfil de competências do funcionário. Da mesma forma, o processo de treinamento deve enfatizar a visão sistêmica da organização e o recrutamento pode buscar funcionários com um perfil de competências que atendam a vários tipos de funções dentro da empresa.

- Fatores Externos - podem ser classificados em dois tipos: fatores sociais e fatores de mercado. Os fatores sociais correspondem às formas pelas quais a sociedade regula o trabalho e as relações de trabalho, tais como a cultura de trabalho dessa sociedade, a legislação, as intervenções do Estado e de sindicatos. Os fatores sociais costumam exercer mais um papel de restrição do que de definição de características do modelo de gestão de pessoas. Os fatores de mercado, fundamentais para a construção do modelo, definem o perfil de competências organizacionais exigido pelo negócio. Alguns autores chegam a afirmar que, no mundo competitivo, a empresa é vista como um "portfólio de competências", sendo que a empresa que melhor dominar a competência essencial de determinado setor será a vencedora (PRAHALAD e HAMEL, 2005).

Os elementos formais que compõem o modelo de gestão de pessoas são os princípios, as políticas e os processos que interferem nas relações humanas no interior das organizações. Por princípios entendem-se as orientações de valor e as crenças básicas que determinam o modelo e são adotadas pela empresa. Como exemplos de valor, podem-se citar honestidade, integridade, respeito, enfim, parâmetros de relacionamento entre as pessoas e das pessoas com a organização. As políticas, por sua vez, estabelecem diretrizes de atuação que buscam objetivos de médio e de longo prazo nas relações organizacionais. Em geral, são orientadoras e integradoras dos processos especificamente voltados para a gestão de pessoas. Os processos de gestão de pessoas são os elementos mais visíveis do modelo e constituem a sequência de atividades que visam alcançar determinado resultado, 
pela transformação de determinados recursos. Como exemplos de processos de gestão de pessoas, podem-se citar capacitação e sucessão, administração de carreiras, avaliação de desempenho, recrutamento e seleção, entre outros.

\subsubsection{Dimensão Sistemas de Recompensa}

Embora a dimensão Sistemas de Recompensa seja muitas vezes incluída no modelo de gestão de pessoas, ao se definir ou analisar o desenho organizacional de uma empresa, esta dimensão apresenta-se como de fundamental importância. Mais que o poder de compra ou o padrão de vida que o salário ou outras formas de recompensa podem proporcionar, sua importância está ligada a um valor simbólico, que representa quanto o indivíduo vale para a organização (HIPÓLITO, 2002). Esse caráter simbólico reforça a relação entre aquilo que a organização valoriza ou quer estimular e a prática de recompensas, de modo a incentivar comportamentos e ações que agreguem valor. O sistema de recompensa deve estar alinhado à contribuição dos profissionais para a organização, de forma a não gerar desequilíbrio entre a estrutura compensatória vigente e os resultados obtidos em sua prática. Em outras palavras, o indivíduo que percebe seu trabalho como valorizado dentro de uma organização, valorização esta que é traduzida na forma de recompensas, tende a buscar um desempenho cada vez melhor em suas atividades individuais, o que se reflete, geralmente, em melhores resultados para seu grupo de trabalho e para a organização como um todo. Por outro lado, o indivíduo que desempenha suas atividades, mas não obtém o devido retorno na forma de recompensa, tende a perder o interesse e a motivação para o trabalho, interpretando que a organização também não tem interesse em reter seu talento.

Tradicionalmente, o cargo é utilizado como elemento decodificador do valor agregado pelos profissionais, sendo a principal referência na definição de sua recompensa. Essa prática se mostrava eficiente quando se esperava que os profissionais desempenhassem apenas o conjunto de atividades definidas pelo cargo. Atualmente, porém, diante da realidade dinâmica das organizações, as atividades dos profissionais são influenciadas pelas necessidades organizacionais em constante mudança e pelo nível de competência do próprio profissional. Neste 
novo contexto, o uso do cargo, que despersonifica a recompensa, impede que se reconheça de forma diferenciada a contribuição de cada indivíduo para a organização. Visando alinhar o sistema de recompensas com o cenário competitivo, surgiram alternativas baseadas no uso do conceito de competências, na intensificação da remuneração variável e na adoção de benefícios flexíveis.

A estruturação de um sistema de recompensas deve considerar, dentre as várias formas de composição, aquelas que sejam mais alinhadas à filosofia de gestão da organização e àquilo que se quer valorizar e estimular. Os possíveis componentes de um sistema de recompensas são apresentados a seguir:

- Salário - parcela fixa da remuneração, paga regularmente, representa o principal componente oferecido pelas organizações, principalmente em relações estáveis de trabalho;

- Remuneração Variável - é atrelada ao acompanhamento do desempenho do profissional, podendo ou não existir, com maior ou menor intensidade, em vista dos resultados alcançados. No passado, a remuneração variável era restrita a algumas posições da área comercial (na forma de porcentagem sobre as vendas) ou da alta direção (na forma de bônus); contudo, percebese que atualmente a utilização desta forma de recompensa tem crescido como alternativa à parcela fixa de compensação;

- Benefícios - os pacotes de benefícios, uma forma de compensação indireta, foram utilizados inicialmente para atender necessidades básicas da maioria dos profissionais, procurando proporcionar uma vida fora do trabalho mais gerenciável e segura. Como exemplos de benefícios, podem-se citar assistência médica, auxílio refeição, auxílio transporte, auxílio creche, assistência odontológica, entre outros. Com o tempo, os benefícios se transformaram em um mecanismo de atração e retenção de pessoas. Como podem representar uma parcela significativa da folha de pagamento, é importante administrá-los com cuidado. Deve-se notar que, enquanto a organização enxerga o custo gerado pelo benefício, o profissional percebe o valor que ele representa. Em vista disto, como os trabalhadores dentro de uma mesma organização percebem o valor de cada benefício de forma diferenciada, algumas empresas estão oferecendo planos de benefícios 
flexíveis, nos quais o profissional escolhe a totalidade ou parte do conjunto de benefícios oferecidos.

As possibilidades de estruturar o sistema de recompensas são inúmeras, o que torna crítica a escolha de formas alinhadas com as características da organização e do ambiente no qual ela se insere. Percebe-se, portanto, a importância desta dimensão para o desenho organizacional de uma empresa.

\subsubsection{Dimensão Processos}

Outra dimensão do desenho organizacional é a dimensão Processos. O conceito de processo tem recebido grande ênfase na atualidade. De uma forma geral, um processo pode ser definido como um conjunto de atividades que transformam recursos ou entradas - materiais, mão de obra, informação, recursos financeiros, etc. - em resultados ou saídas (bens ou serviços), conforme a Figura 2.4:

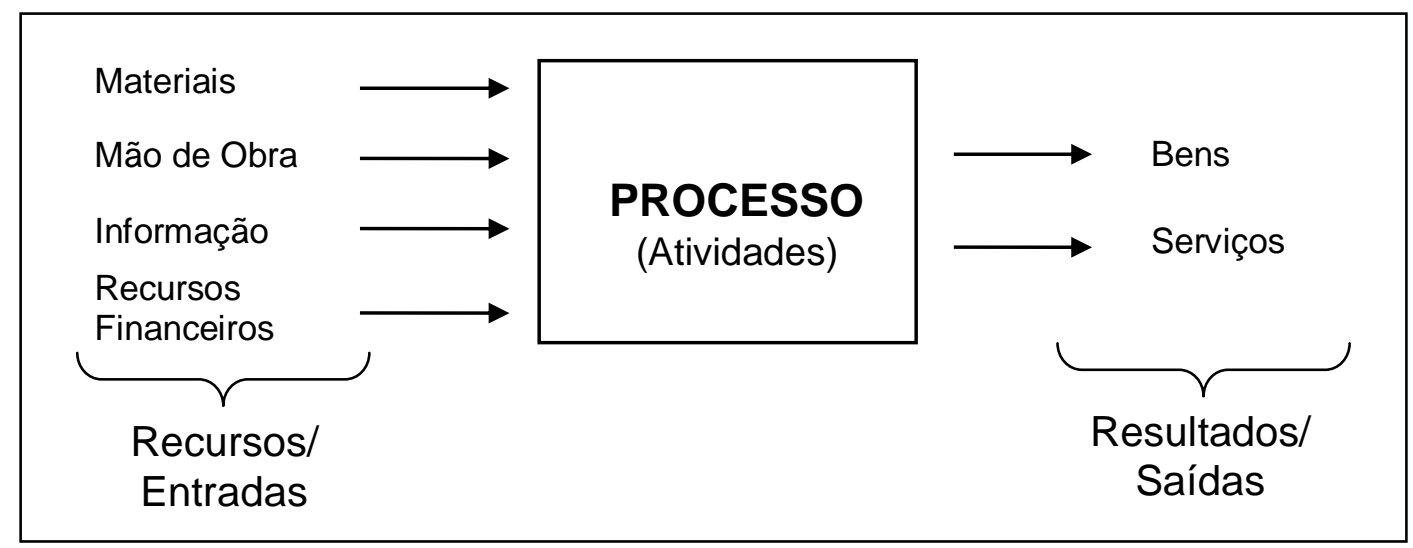

Figura 2.4 - Representação de Processo de Trabalho (elaborada pela autora)

Davenport (1993) define um processo como "um conjunto de atividades estruturadas e medidas destinadas a resultar num produto especificado para um determinado cliente ou mercado". Ao se adotar uma visão por processo dentro de uma organização, enfatiza-se a maneira como o trabalho é realizado. Um processo é, portanto, uma ordenação específica das atividades de trabalho no tempo e no espaço, com um começo, um fim e entradas e saídas claramente identificadas. Harrington (1991) ressalta a agregação de valor, definindo processo como "qualquer 
atividade ou grupo de atividades que recebe um insumo, agrega-lhe valor e fornece um produto ou uma saída a um cliente interno ou externo. Processos utilizam recursos de uma organização para produzir resultados".

Os processos de uma organização podem ser agrupados em três categorias:

(1) Processos operacionais - processos que criam, produzem e fornecem bens ou serviços que os clientes desejam, ou seja, processos relacionados às atividades-fim;

(2) Processos de decisão - processos cujo resultado são decisões que se referem aos processos operacionais, visando comandá-los;

(3) Processos administrativos - processos que dão suporte à realização dos processos operacionais e dos processos de decisão.

Processos operacionais, de decisão e administrativos apresentam várias características em comum. Todos envolvem sequências de atividades ligadas e interdependentes, que em conjunto transformam entradas em saídas; possuem início e fim, com limites que podem ser definidos com razoável precisão; possuem clientes, que podem ser internos ou externos à organização. As diferenças entre eles estão na natureza das saídas. A Figura 2.5 apresenta um esquema da forma como os três tipos de processos se inter-relacionam:

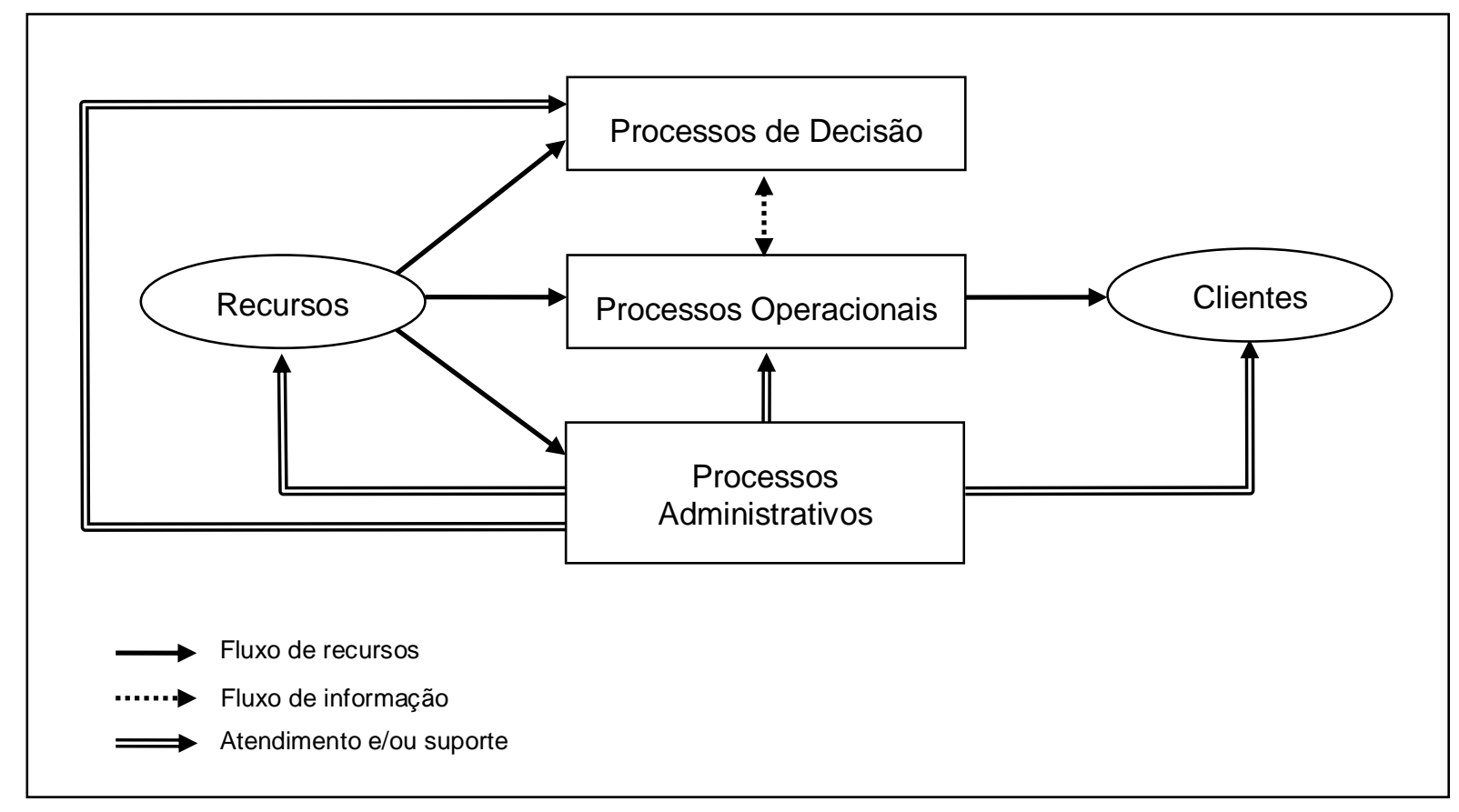

Figura 2.5 - Inter-relacionamento entre os tipos de processos (elaborada pela autora) 
Pode-se observar, na Figura 2.5, que existem três tipos de fluxos - fluxo de recursos, fluxo de informação e atendimento e/ou suporte. Nos processos operacionais, existe um fluxo de recursos para a produção de bens ou serviços para os clientes, com atendimento ou suporte dos processos administrativos. Os processos de decisão relacionam-se com os processos operacionais através de um fluxo de informações em duplo sentido, além de receberem, também, suporte dos processos administrativos. Observa-se, ainda, que os processos administrativos são necessários não somente para atender ou dar suporte aos processos operacionais e de decisão, mas também para a obtenção de recursos e para o atendimento de clientes.

Garvin (2002) propõe uma forma mais ampla de se encarar os processos, baseando-se em três abordagens de processos organizacionais - processos de trabalho, processos comportamentais e processos de mudança - e em três processos de gestão mais comuns - processo de estabelecimento de diretrizes, processo de negociação e vendas e processo de monitoramento e controle. Os processos organizacionais são definidos da seguinte forma:

- Processos de trabalho - sequências de atividades que transformam inputs em outputs;

- Processos comportamentais - padrões de comportamento e formas de agir e interagir amplamente compartilhados;

- Processos de mudança - sequências de eventos ao longo do tempo que alteram o caráter, a escala e a identidade da organização (exemplos: criação, crescimento, transformação, declínio).

Os três processos de gestão mais comuns apresentam os seguintes propósitos:

- Processo de estabelecimento de diretrizes - estabelecer a direção e as metas organizacionais;

- Processo de negociação e vendas - obter os recursos e o suporte necessários para a realização do trabalho;

- Processo de monitoramento e controle - acompanhar o andamento das atividades e do desempenho da organização. 
A partir desses vários tipos de processo, Garvin (2002) propõe uma estrutura unificada para ação, visando uma compreensão integrada e dinâmica, conforme ilustrado no Quadro 2.3:

Quadro 2.3 - Estrutura para Ação

\begin{tabular}{|c|c|c|c|c|}
\hline & \multicolumn{3}{|c|}{ Processos Organizacionais } \\
\hline & & $\begin{array}{l}\text { Processos de } \\
\text { Trabalho }\end{array}$ & $\begin{array}{c}\text { Processos } \\
\text { Comportamentais }\end{array}$ & Processos de Mudança \\
\hline \multirow{3}{*}{ 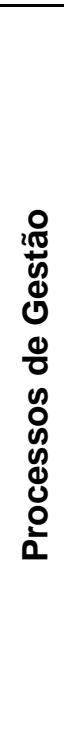 } & $\begin{array}{l}\text { Processo de } \\
\text { estabelecimento } \\
\text { de diretrizes }\end{array}$ & $\begin{array}{l}\text { Existem metas } \\
\text { claras para o } \\
\text { desempenho } \\
\text { estratégico e } \\
\text { operacional? }\end{array}$ & $\begin{array}{l}\text { Existem abordagens } \\
\text { bem especificadas de } \\
\text { comunicação, tomada } \\
\text { de decisão e } \\
\text { aprendizagem? }\end{array}$ & $\begin{array}{l}\text { Existe uma direção clara } \\
\text { e racional da mudança? }\end{array}$ \\
\hline & $\begin{array}{l}\text { Processos de } \\
\text { negociação e } \\
\text { vendas }\end{array}$ & $\begin{array}{l}\text { Foram obtidos os } \\
\text { acordos e } \\
\text { recursos } \\
\text { necessários? }\end{array}$ & $\begin{array}{l}\text { Existe ampla aceitação } \\
\text { das abordagens de } \\
\text { comunicação, tomada } \\
\text { de decisão e } \\
\text { aprendizagem } \\
\text { desejadas? }\end{array}$ & $\begin{array}{l}\text { Outras pessoas na } \\
\text { organização estão } \\
\text { convencidas de que as } \\
\text { mudanças são } \\
\text { necessárias e que as } \\
\text { propostas estão corretas? }\end{array}$ \\
\hline & $\begin{array}{l}\text { Processo de } \\
\text { monitoramento } \\
\text { e controle }\end{array}$ & $\begin{array}{l}\text { É conhecido o } \\
\text { quanto o } \\
\text { desempenho } \\
\text { alcança os } \\
\text { planos? }\end{array}$ & $\begin{array}{l}\text { É conhecido o quanto o } \\
\text { comportamento atual } \\
\text { promove as abordagens } \\
\text { de comunicação, } \\
\text { tomada de decisão e } \\
\text { aprendizagem } \\
\text { desejadas? }\end{array}$ & $\begin{array}{l}\text { É conhecido se os marcos } \\
\text { críticos foram alcançados } \\
\text { e mudanças planejadas } \\
\text { foram implantadas? }\end{array}$ \\
\hline
\end{tabular}

Fonte: Garvin (2002)

A abordagem por processo de trabalho é provavelmente a mais familiar dentro das organizações. Garvin (2002) engloba neste tipo de processo os processos operacionais e os administrativos.

A abordagem de processos comportamentais tem origem na teoria das organizações e em dinâmicas de grupo e foca na existência de padrões comportamentais que refletem a forma como uma organização atua e interage. Os processos de tomada de decisão e de comunicação são exemplos de padrões de comportamento. Os padrões de comportamento são muitas vezes inconscientes e normalmente estão amplamente disseminados, sendo adotados pela maioria dos membros da organização.

A abordagem de processos de mudança tem origem na gestão estratégica, na teoria das organizações e na psicologia social e foca nas sequências de eventos ao longo do tempo. Estas sequências descrevem como indivíduos, grupos e organizações se adaptam, se desenvolvem e crescem. Processos de mudança são 
dinâmicos e intertemporais. Pode-se citar como exemplo de processo de mudança o ciclo de vida da organização.

Ao adotar-se uma visão por processo em uma organização, tem-se um enfoque do trabalho como um todo, e não apenas das partes que ocorrem em cada departamento, visão esta que se insere na perspectiva da teoria dos sistemas. Indo além, ao se adotar uma visão sistêmica da organização, percebe-se a interação entre processos de trabalho, comportamentais e de mudança.

No modelo da estrela apresentado por Galbraith em 2009, a dimensão processos engloba a dimensão "informação", representada pelo fluxo de informações que devem percorrer toda a organização por meio dos processos, tanto processos-fim como processos administrativos e de decisão.

A informação exerce um papel cada vez mais importante dentro das organizações, sendo o elemento alimentador e integrador de todas as atividades. As informações devem fluir através de toda a organização para que esta alcance seus objetivos. O conceito de informação pode ser definido como "um conjunto de fatos (dados) organizado de modo a fazer sentido para o destinatário" (TURBAN et al, 2003). Um sistema de informação (SI) é um conjunto de componentes interrelacionados com a finalidade de coletar, recuperar, processar, armazenar e distribuir informação através da organização para facilitar o planejamento, o controle, a coordenação e o processo decisório. Desta forma, um sistema de informação transforma a informação em uma forma utilizável para a coordenação do fluxo de trabalho de uma empresa. Uma vez que os processos de uma organização (operacionais e administrativos), estejam eles formalizados ou não, são formados pelo conjunto de atividades que ela exerce, é essencial que os sistemas de informação estejam alinhados com os processos. Os sistemas de informação de uma organização e seus processos são inseparáveis.

Embora nem todos os sistemas de informação sejam baseados em tecnologia de informação (TI), é fundamental observar a importância da TI na chamada "nova economia", em que a competição no mercado alcança níveis globais e fatos que ocorrem em um ponto do planeta podem ter repercussão mundial (LAURINDO et al, 2006). Na "nova economia", a TI passa a ser vista como fonte de criação de novas estratégias de negócio, de novas estruturas organizacionais e de novas formas de relacionamento entre empresas e entre empresas e consumidores. Desde o início da 
discussão sobre os processos nas empresas, ficou claro que estes devem ser repensados e melhorados de forma alinhada à estratégia do negócio, muitas vezes com a utilização de novas aplicações de TI. Em muitos casos, foi possível a implantação da gestão por processos nas organizações justamente por meio da TI. Além disso, a necessidade de alinhamento estratégico entre TI e negócio tem sido estudada e aceita por vários pesquisadores como forma de se atingir resultados mais eficazes dos investimentos feitos em tecnologia (HENDERSON e VENKATRAMAN, 1993).

No final da década de 1970 e início da década de 1980, muitas organizações passaram a investir em TI, mesmo sem adotar inicialmente uma explícita perspectiva de processo. À medida que os sistemas eram implantados, no entanto, tornou-se evidente a necessidade de uma visão interfuncional, ligando os vários departamentos da organização, uma vez que era necessário analisar os processos de produção do início até o fim. Hammer e Champy (1993) comentam que a tecnologia de informação moderna e atualizada integra os esforços de mudança, sendo um capacitador essencial, por permitir às empresas a reengenharia de seus processos. Entretanto, estes autores alertam que o uso inadequado da $\mathrm{TI}$ pode bloquear a mudança se utilizada de modo inadequado, ou seja, se for usada reforçando a divisão dos setores. Nolan e Crosson (1996) comentam que a utilização da TI associada à tradicional estrutura hierárquica pode facilmente ser utilizada para preservar o status quo. Estes autores defendem a necessidade de substituição da estrutura hierárquica tradicional, permitindo o surgimento de uma nova estrutura organizacional possibilitada pela $\mathrm{TI}$, em um processo que denominam "destruição criativa".

Ao iniciarem a informatização de seus sistemas, muitas organizações desenvolveram sistemas de informação para apoiar suas diferentes funções e níveis organizacionais. Muitos desses sistemas, construídos ao longo dos anos para atender diferentes funções ou unidades de negócio, não "conversavam" uns com os outros, dificultando sobremaneira a obtenção de informações. Essa fragmentação evidenciou a necessidade de se construir sistemas de informação integrando as várias funções da organização. Os primeiros sistemas integrados surgiram na década de 1960, sendo que seu foco principal era o controle de inventário (Nikolopoulos et al, 2003). Estes sistemas evoluíram para a lógica de programação 
conhecida como MRP (Materials Requirements Planning), com o objetivo de automatizar o cálculo de necessidades de materiais. Na década de 1980, surgiu o MRP II (Manufacturing Resources Planning), que passou a integrar todos os recursos da manufatura da organização. Na década de 1990, o MRP II evoluiu para o sistema ERP (Enterprise Resource Planning), que consiste em um software de gestão de negócios, integrando todas as funções da organização.

A simples implantação de tecnologia de informação, no entanto, não garante a melhoria de um processo. Davenport (1993) considera a TI como um importante recurso a ser utilizado na melhoria de processos, porém, enfatiza a importância de se refletir sobre os processos e sobre sua inovação e melhoria antes do investimento em novas tecnologias de informação, sob o risco de não se obter as melhorias desejadas.

\subsubsection{Dimensão Estrutura Organizacional (Organograma)}

Muitas organizações modernas possuem estruturas funcionais e hierárquicas, que dividem a organização em departamentos, cada um cuidando de tarefas específicas, baseando-se na lógica de que o ótimo de cada parte leva ao ótimo do todo (Figura 2.6).

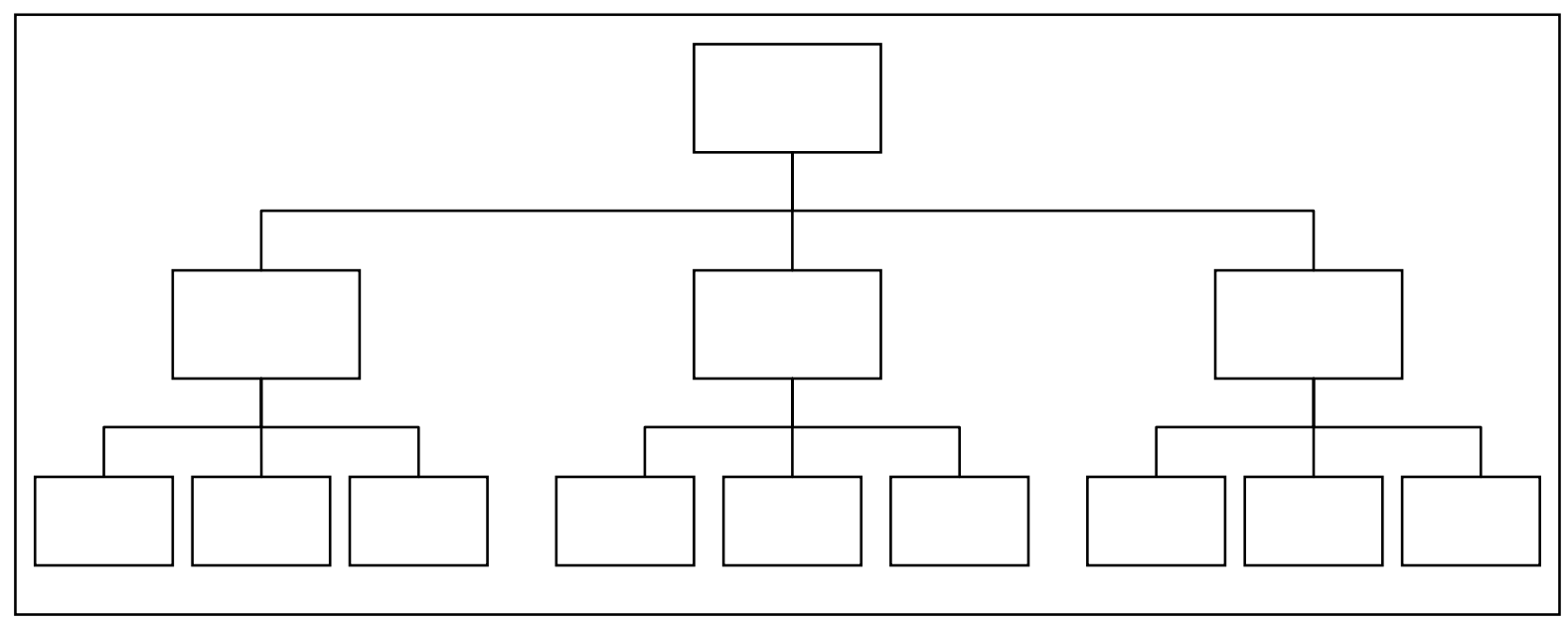

Figura 2.6 - Estrutura Organizacional Vertical (Funcional) (elaborada pela autora) 
Neste modelo, profundamente arraigado na mente das pessoas, são agrupadas no mesmo setor pessoas que realizam atividades dentro de uma mesma área técnica, facilitando a atribuição, a localização e a cobrança de tarefas, uma vez que a divisão do trabalho é bastante clara, além de favorecer a especialização e reduzir o número de chefes, já que as decisões seguem a hierarquia. A estrutura hierárquica, no entanto, acaba por isolar os departamentos, empobrecendo a coordenação das atividades e limitando a comunicação (GARVIN, 2002). O trabalho acaba sendo fragmentado e compartimentado, o que dificulta a realização das tarefas. Nas últimas décadas, porém, mesmo apresentando estruturas funcionais bem organizadas, muitas organizações passaram a perder competitividade, devido a fatores como falta de flexibilidade e rapidez nas mudanças, aumento das expectativas e exigências dos consumidores, desenvolvimento e implantação de aplicações de TI que enxergam as atividades da organização como um todo, e não em setores ou departamentos, entre outros.

$\mathrm{Na}$ tentativa de encontrar uma melhor compreensão da organização e conseguir as melhorias necessárias para sua sobrevivência, a abordagem por processo fornece uma alternativa para essa visão estática e fragmentada. É necessário que as atividades da organização sejam encaradas não como funções, departamentos ou produtos, mas como processos.

A gestão por processos evidencia a sequência de atividades que são realizadas, cruzando departamentos e níveis hierárquicos, até a saída dos produtos. A produção de um bem ou serviço ocorre por meio de uma série de atividades interligadas que atravessam os setores ou departamentos da organização com o objetivo de atender o cliente final (Figura 2.7):

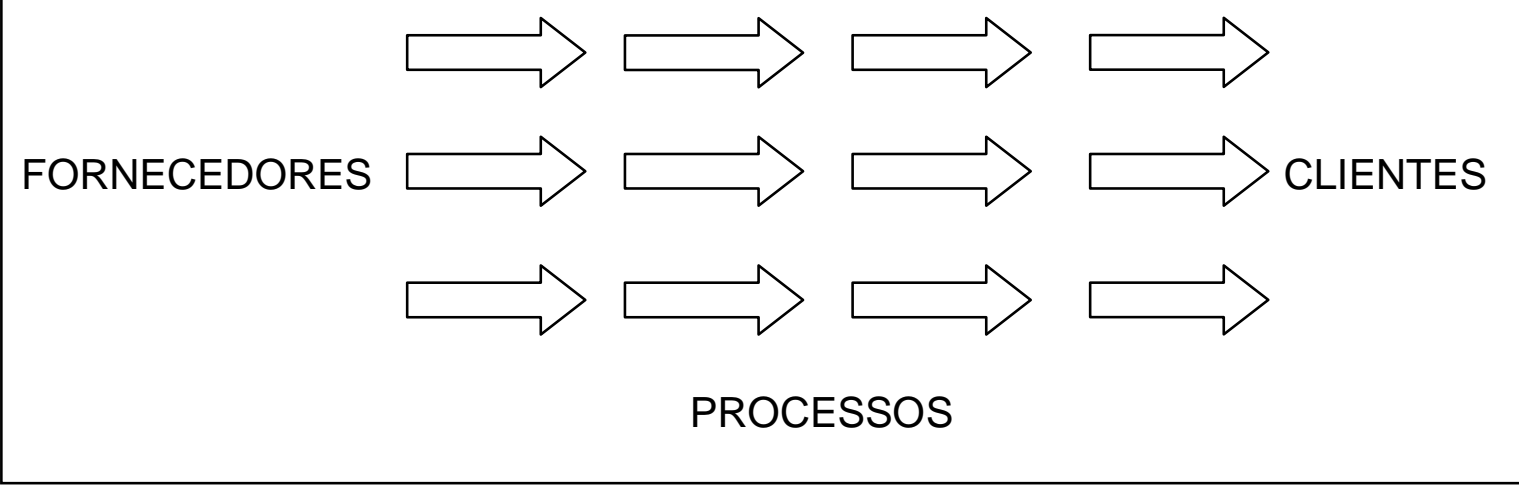

Figura 2.7 - Estrutura Organizacional Horizontal (por Processo) (elaborada pela autora) 
A gestão por processos distingue-se da estrutura funcional hierárquica e vertical, pois enxerga a organização de uma forma horizontal, com foco nos processos. Enquanto a estrutura hierárquica é, tipicamente, uma visão fragmentada e estática das responsabilidades e das relações de subordinação, a estrutura por processo é uma visão dinâmica da forma pela qual a organização produz valor. Quando uma organização apresenta foco em seus processos, baseia-se na lógica de que o ótimo do sistema como um todo prevalecerá sobre o ótimo das partes, já que o resultado global é o mais importante, e não apenas a tarefa individual (CARVALHO et al, 2005).

Muitas vezes, no entanto, a adoção da gestão por processos ocorre simultaneamente com a existência de uma estrutura funcional, surgindo como consequência a adoção de uma estrutura híbrida. Segundo Vasconcellos (2002), "quando duas ou mais formas de estrutura são utilizadas simultaneamente sobre os mesmos membros de uma organização, a estrutura resultante chama-se matricial". Um aspecto particular da estrutura matricial é a dupla ou múltipla subordinação. No caso de uma matriz formada pela estrutura funcional com uma estrutura por processos, um dado funcionário responde simultaneamente ao gerente funcional da área técnica em que está alocado e ao gestor do processo ou processos do qual participa. A Figura 2.8 apresenta um esquema de estrutura matricial formada por uma estrutura funcional associada com uma estrutura por processos:

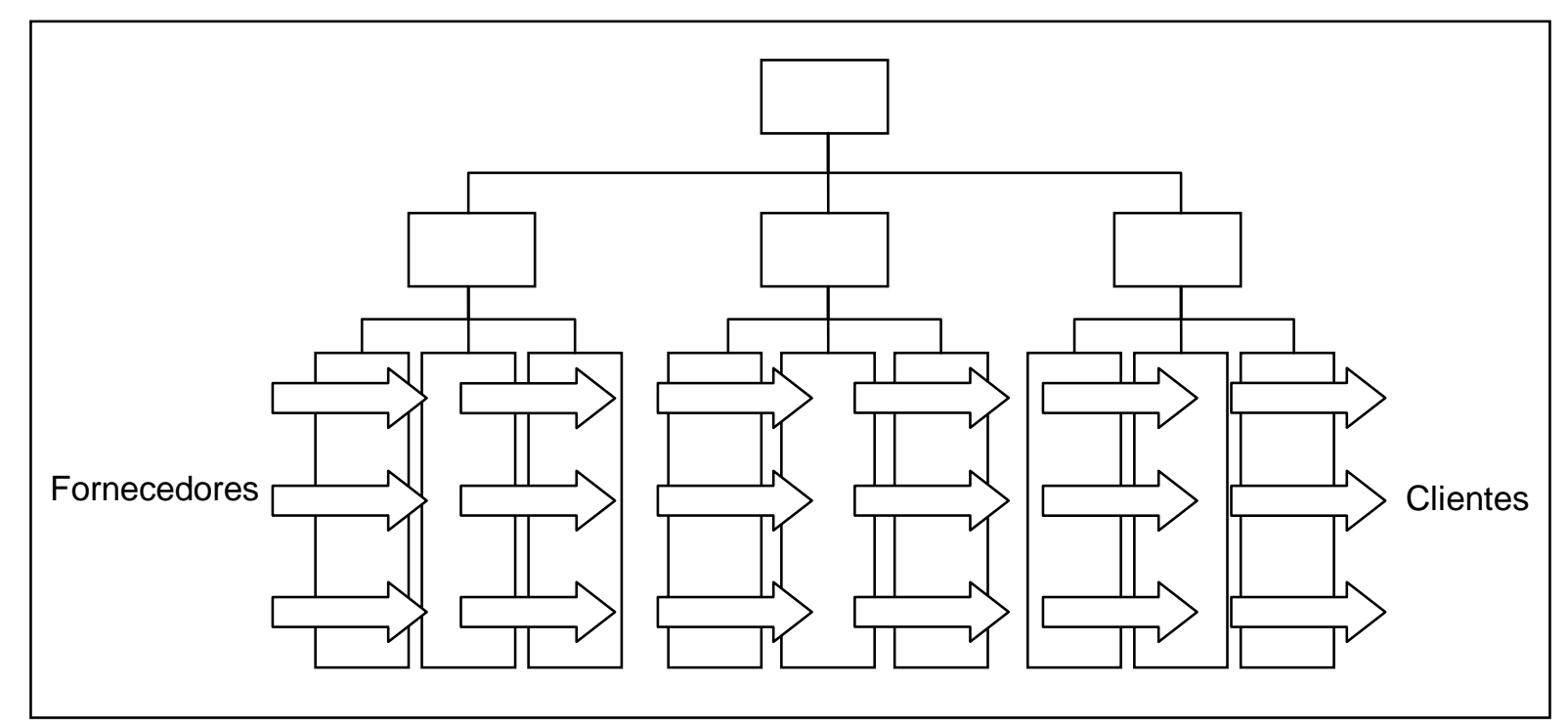

Figura 2.8 - Esquema de Estrutura Matricial (Funcional x Processos) (elaborada pela autora) 
De acordo com a dosagem de cada estrutura na matriz, pode variar o grau de balanceamento da estrutura matricial. Uma matriz é chamada de balanceada quando os dois tipos de estrutura que a compõem apresentam igual peso, ou seja, os gerentes funcionais e os gestores de processos dividem igual autoridade. Por outro lado, é comum haver um desbalanceamento na matriz, levando ao que Vasconcellos (2002) chama de índice de matricialidade. Em uma matriz em que ambas as estruturas apresentam a mesma ênfase, o índice de matricialidade ocupa uma posição intermediária. No caso da estrutura funcional apresentar maior ênfase (estrutura matricial funcional), os gerentes funcionais atuarão em nível hierárquico superior aos gestores de processo, e vice-versa.

A abordagem por processo implica em uma forte ênfase sobre a melhoria da forma como o trabalho é feito. A adoção de uma perspectiva por processo significa a adoção do ponto de vista do cliente. Uma vez que os processos são a forma pela qual uma organização faz o necessário para produzir valor para seus clientes, devese oferecer bens e serviços que atendam suas expectativas, empregando processos eficientes e eficazes. Consequentemente, os processos devem ser medidos em termos de custo, tempo, qualidade ou outras dimensões que tragam valor para o cliente. Essas medidas tornam-se os critérios para a avaliação do valor de uma inovação e para o estabelecimento de programas de aperfeiçoamento.

Outro autor que explora com bastante profundidade o tema estrutura organizacional é Mintzberg. Segundo Mintzberg (2003), toda atividade humana organizada dá origem a duas exigências fundamentais e opostas: a divisão do trabalho em várias tarefas a serem executadas e a coordenação dessas tarefas para a realização da atividade. A estrutura de uma organização pode ser definida como a soma total das maneiras pelas quais o trabalho é dividido em tarefas distintas e, depois, como a coordenação é realizada entre as tarefas. Mintzberg (2003) defende que a estrutura deve ser desenhada de forma que seus elementos sejam selecionados para a obtenção de uma consistência ou harmonia interna, bem como uma consistência básica com a situação da organização - seu tamanho, idade, tipo de ambiente em que funciona, sistema técnico que utiliza, entre outros. 
Para começar a definir uma estrutura, devem-se considerar as diferentes partes que compõem a organização e as pessoas que pertencem a cada uma dessas partes, conforme a Figura 2.9, apresentada a seguir:

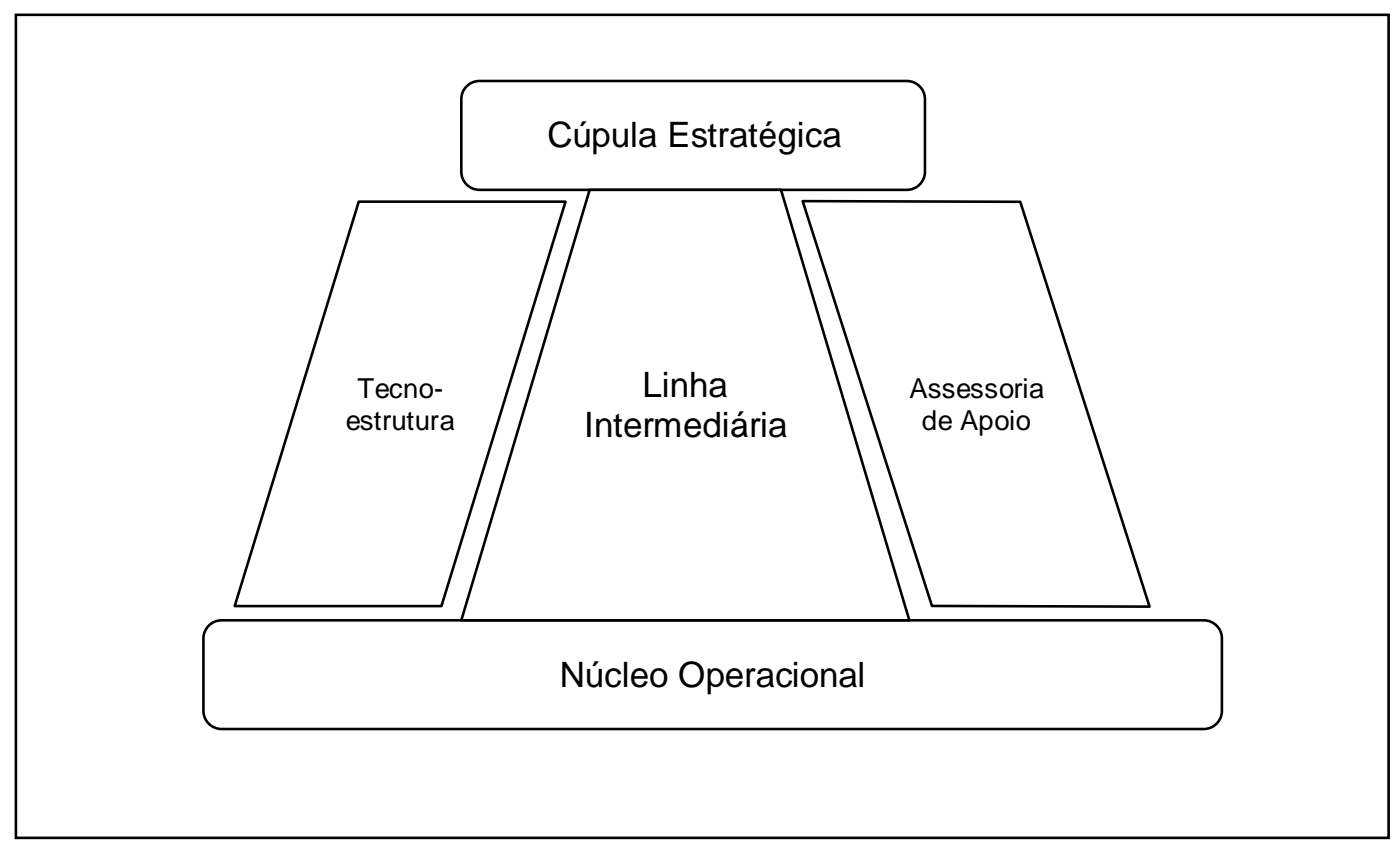

Figura 2.9 - As cinco partes básicas da organização (adaptada de Mintzberg, 2003)

$\mathrm{Na}$ base da organização, encontram-se os operadores, as pessoas que executam o trabalho básico de fabricar os produtos e prestar os serviços, formando o núcleo operacional. À medida que a organização cresce e adota uma divisão mais complexa do trabalho, aumenta a necessidade de supervisão direta. Torna-se necessária a presença de uma gerência em tempo integral, situada na posição chamada cúpula estratégica. À medida que a organização torna-se mais elaborada, são necessários mais gerentes, criando uma hierarquia de autoridade entre o núcleo operacional e a cúpula estratégica, chamada de linha intermediária. Ao crescer ainda mais, a organização pode aumentar a padronização como meio de coordenar o trabalho. A responsabilidade por grande parte dessa padronização é transferida a um grupo de pessoas chamadas de analistas, formando a tecnoestrutura. Os analistas podem ser responsáveis, por exemplo, por atividades como planejamento estratégico, controladoria, pesquisa operacional, programação da produção, etc. A tecnoestrutura está posicionada fora da hierarquia da linha de autoridade e representa uma divisão do trabalho administrativo, enfraquecendo, de certa forma, o controle que os gerentes exercem sobre a operação. Por fim, ao crescer, a 
organização pode criar unidades de assessoria de natureza diferente, para fornecer serviços indiretos, como consultoria jurídica, relações públicas, refeitório, etc. Essa parte da organização é denominada assessoria de apoio.

Os parâmetros de design, componentes básicos da estrutura organizacional, são definidos como as alavancas que podem ser acionadas para afetar a divisão do trabalho e a coordenação das tarefas na organização. O Quadro 2.4 apresenta um conjunto de nove parâmetros de design, classificados em quatro grupos:

Quadro 2.4 - Parâmetros de Design

\begin{tabular}{|c|c|c|}
\hline Grupo & Parâmetro de design & Conceitos relacionados \\
\hline Design das posições & $\begin{array}{l}\text { Especialização da tarefa } \\
\text { Formalização do comportamento } \\
\text { Treinamento e doutrinação }\end{array}$ & $\begin{array}{l}\text { Divisão básica do trabalho } \\
\text { Padronização do conteúdo do trabalho } \\
\text { Sistema de fluxos regulamentados } \\
\text { Padronização das habilidades }\end{array}$ \\
\hline $\begin{array}{l}\text { Design da } \\
\text { superestrutura }\end{array}$ & $\begin{array}{l}\text { Agrupamento em unidades } \\
\text { Tamanho da unidade }\end{array}$ & $\begin{array}{l}\text { Supervisão direta } \\
\text { Divisão administrativa do trabalho } \\
\text { Sistemas de autoridade formal, de fluxos } \\
\text { regulamentados, de comunicação } \\
\text { informal e de constelações de trabalho } \\
\text { Organograma } \\
\text { Sistema de comunicação informal } \\
\text { Supervisão direta } \\
\text { Amplitude de controle }\end{array}$ \\
\hline $\begin{array}{l}\text { Design dos vínculos } \\
\text { laterais }\end{array}$ & $\begin{array}{l}\text { Sistemas de planejamento e } \\
\text { controle }\end{array}$ & $\begin{array}{l}\text { Padronização dos outputs } \\
\text { Sistemas de fluxos regulamentados } \\
\text { Ajuste mútuo } \\
\text { Sistemas de comunicação informal, } \\
\text { constelações de trabalho e processos de } \\
\text { decisão ad hoc }\end{array}$ \\
\hline $\begin{array}{l}\text { Design do sistema } \\
\text { de tomada de } \\
\text { decisão }\end{array}$ & $\begin{array}{l}\text { Descentralização vertical } \\
\text { Descentralização horizontal }\end{array}$ & $\begin{array}{l}\text { Divisão administrativa do trabalho } \\
\text { Sistemas de autoridade formal, fluxos } \\
\text { regulamentados, constelações de } \\
\text { trabalho e processos de decisão ad hoc } \\
\text { Divisão administrativa do trabalho } \\
\text { Sistemas de comunicação informal, } \\
\text { constelações de trabalho e processos de } \\
\text { decisão ad hoc }\end{array}$ \\
\hline
\end{tabular}

Fonte: Mintzberg (2003) 
Mintzberg (2003) argumenta que tanto os parâmetros do design quanto os fatores situacionais devem ser rigorosamente agrupados para criar o que chama de configurações. Dependendo de como as escolhas são feitas, diferentes configurações podem ser desenhadas. São apresentadas cinco configurações básicas:

- Estrutura Simples - baseada na supervisão direta, em que a cúpula estratégica é a parte principal;

- Burocracia Mecanizada - baseada na padronização dos processos de trabalho, em que a tecnoestrutura é a parte principal;

- Burocracia Profissional - baseada na padronização de habilidades, em que o núcleo operacional é a parte principal;

- Forma Divisionada - baseada na padronização dos outputs, em que a linha intermediária é a parte principal;

- Adhocracia - baseada em ajustamento mútuo, em que a assessoria de apoio, às vezes acompanhada do núcleo operacional, é a parte principal.

Em cada configuração, um mecanismo de coordenação diferente é predominante, uma parte diferente da organização exerce o papel mais importante e um tipo diferente de descentralização é utilizado, conforme é apresentado no Quadro 2.5, a seguir:

Quadro 2.5 - As Cinco Configurações Básicas

\begin{tabular}{|l|l|l|l|}
\hline \multicolumn{1}{|c|}{$\begin{array}{c}\text { Configuração } \\
\text { estrutural }\end{array}$} & \multicolumn{1}{|c|}{$\begin{array}{c}\text { Mecanismo de } \\
\text { coordenação }\end{array}$} & \multicolumn{1}{|c|}{$\begin{array}{c}\text { Parte chave da } \\
\text { organização }\end{array}$} & \multicolumn{1}{|c|}{$\begin{array}{c}\text { Tipo de } \\
\text { descentralização }\end{array}$} \\
\hline Estrutura simples & Supervisão direta & Cúpula estratégica & $\begin{array}{l}\text { Centralização vertical e } \\
\text { horizontal }\end{array}$ \\
\hline Burocracia mecanizada & $\begin{array}{l}\text { Padronização dos } \\
\text { processos de trabalho }\end{array}$ & Tecnoestrutura & $\begin{array}{l}\text { Descentralização } \\
\text { horizontal limitada }\end{array}$ \\
\hline Burocracia profissional & $\begin{array}{l}\text { Padronização das } \\
\text { habilidades }\end{array}$ & Núcleo operacional & $\begin{array}{l}\text { Descentralização } \\
\text { vertical e horizontal }\end{array}$ \\
\hline Forma divisionada & $\begin{array}{l}\text { Padronização dos } \\
\text { outputs }\end{array}$ & Linha intermediária & $\begin{array}{l}\text { Descentralização } \\
\text { vertical limitada }\end{array}$ \\
\hline Adhocracia & Ajustamento mútuo & Assessoria de apoio & $\begin{array}{l}\text { Descentralização } \\
\text { seletiva }\end{array}$ \\
\hline
\end{tabular}

Fonte: Mintzberg (2003) 
A adoção de determinada configuração estrutural é decorrência de cinco forças que geralmente existem em uma organização, cada força exercida por uma de suas partes em uma diferente direção. A cúpula estratégica exerce uma força para a centralização, o que the permite manter o controle sobre a tomada de decisão. Isso é obtido quando a supervisão direta é utilizada para a coordenação, surgindo a configuração denominada Estrutura Simples. A tecnoestrutura exerce força para a padronização, principalmente dos processos de trabalho, representando uma força em direção à descentralização limitada. Na situação em que as condições favoreçam essa força, surge uma Burocracia Mecanizada. Se o núcleo operacional tentar minimizar a influência dos gerentes e analistas sobre seu trabalho, promove a descentralização horizontal e vertical. Neste caso, os operadores trabalham com relativa autonomia, sendo adotada uma coordenação que favoreça a padronização das habilidades. Assim, é favorecida a força em direção ao profissionalismo, e a organização estrutura-se como Burocracia Profissional. Se os gerentes da linha intermediária buscarem autonomia, irão obtê-la de modo diferente - retirando poder da cúpula estratégica e, se necessário, do núcleo operacional. Desta forma, favorecem a descentralização vertical limitada. Como resultado, exercem uma força em direção à fragmentação da estrutura e surge a configuração denominada Forma Divisionada. No caso da assessoria de apoio ter maior influência, a organização é estruturada em constelações de trabalho nas quais o poder é descentralizado seletivamente e ocorre coordenação por ajustamento mútuo. Neste caso, a força é exercida em direção à colaboração e a organização adota a configuração de Adhocracia.

A abordagem das configurações organizacionais apresentada por Mintzberg (2003) evidencia a influência que o aspecto "poder" tem sobre a estrutura. Alguns fatores de poder também entram no design da estrutura, como a presença do controle externo da organização, as necessidades pessoais de seus vários membros e a "moda do dia". São apresentadas três hipóteses: 
- Quanto maior o controle externo da organização, mais centralizada e formalizada sua estrutura - há evidências que mostram que o controle externo sobre uma organização - seja diretamente por proprietários específicos ou indiretamente por fornecedores dos quais a organização é dependente tende a concentrar o poder de tomada de decisão no topo da hierarquia e a encorajar a utilização de normas e regulamentos para controle interno.

- As necessidades de poder dos membros da organização tendem a gerar estruturas excessivamente centralizadas - geralmente, todos os membros da organização procuram poder, seja para controlar os outros, seja para controlar as decisões que afetam seu próprio trabalho.

- A moda favorece a estrutura do dia (e a cultura), às vezes, mesmo quando inapropriada - quando uma estrutura "está na moda" ela tende a ser adotada por organizações de um mesmo setor.

A análise do poder dentro das organizações também foi estudada por Bertero (2007). Segundo este autor, o poder percorre um itinerário ao longo da existência de uma organização. Em um primeiro momento, o poder encontra-se centrado na figura do proprietário. À medida que é visto como único responsável pelo empreendimento, a ele cabem as decisões em sua quase totalidade. Em tal estágio a firma é pequena e a necessidade de descentralização ainda não surgiu.

Em um segundo momento, o poder organizacional começa a se difundir, o que não significa que o empresário proprietário perca o poder. Os primeiros "influenciadores" do poder passam a ser os profissionais de administração e gestores que não são proprietários. Este núcleo dos "influenciadores internos" se forma por causa da expansão da empresa, ou devido à necessidade de especialistas que dominem habilidades administrativas ou que possuam determinado conhecimento tecnológico. A difusão do poder pode variar de acordo com o momento histórico e as características do ambiente organizacional. Em um mercado relativamente estável, com tecnologias estabelecidas e baixa taxa de mudança e inovação, o poder pode ser difundido para o pessoal de produção e operações industriais. Por outro lado, em um mercado tumultuado, com concorrência acirrada, ou se o produto encontra-se em fase declinante de seu ciclo de vida, é o pessoal de vendas e marketing que assume posições mais destacadas na organização. A 
expansão acelerada da economia, com abertura para novas oportunidades de negócios, favorece a emergência de influenciadores internos das áreas de marketing, estratégia e pesquisa e desenvolvimento. Um aspecto importante a ser explorado nesta fase de difusão é conhecer que relações se estabelecem entre o proprietário e os influenciadores internos. Esta segunda fase também comporta o aparecimento de "influenciadores externos", como o governo, em suas esferas federal, estadual e municipal, governos de outros países, o mercado, incluindo clientes e competidores, o mercado de capitais (acionistas e empresários de recursos financeiros), associações de classe, sindicatos e a própria comunidade em que a empresa se situa. O poder, em seus diversos sistemas e subsistemas sociais, tem suas fontes em diversos agentes, que, por sua vez, estabelecem entre si relações múltiplas. O poder, e a influência que estes influenciadores efetivamente exercerão, dependerá do país, do momento histórico e da configuração do sistema econômico.

Outro autor que realizou pesquisas sobre a estrutura de uma organização e a forma como esta se relaciona com a estratégia foi Chandler (1962). Este autor defende a tese de que diferentes estruturas organizacionais resultam de diferentes tipos de crescimento da empresa. Estratégia pode ser definida como a determinação de metas e objetivos básicos de longo prazo para uma organização, a adoção de uma série de ações e a alocação de recursos necessários para obter essas metas. Estrutura pode ser definida como o desenho organizacional por meio do qual uma empresa é administrada. Este desenho, independentemente de ser formal ou informal, apresenta dois aspectos. Primeiro, inclui linhas de autoridade e comunicação entre os diferentes escritórios e empregados. Segundo, engloba a informação e os dados que fluem através destas linhas de comunicação e autoridade. Estas linhas e esses dados são essenciais para assegurar coordenação, avaliação e planejamento efetivos, necessários para se atingir as metas, executar as políticas e alocar os recursos de uma empresa. A tese deduzida por Chandler (1962) é que a estrutura segue a estratégia, e que um tipo mais complexo de estrutura é o resultado da concatenação de inúmeras estratégias básicas. 


\subsubsection{Cultura Organizacional}

As opções dos elementos do desenho organizacional tendem a reforçar padrões de comportamento dentro da organização, causando impacto na cultura organizacional, e vice-versa. Nos últimos anos, o número de pesquisas sobre o tema cultura organizacional tem aumentado consideravelmente. Segundo Schein (2010), cultura organizacional é o "conjunto de pressupostos básicos que um grupo inventou, descobriu ou desenvolveu ao aprender como lidar com os problemas de adaptação externa e integração interna, e que funcionam bem o suficiente para serem considerados válidos e ensinados a novos membros como forma correta de perceber, pensar e sentir, em relação a esses problemas". Ainda segundo este autor, a cultura de uma organização pode ser aprendida em vários níveis:

- Nível dos artefatos visíveis: constituído pelo ambiente construído da organização, arquitetura, layout, a maneira de as pessoas se vestirem, padrões de comportamento visíveis, documentos públicos, etc. Neste nível, os dados são fáceis de serem obtidos, mas são difíceis de interpretar;

- Nível dos valores que governam o comportamento das pessoas: como é difícil observar e identificar estes valores, é necessário entrevistar os membros da organização ou realizar uma análise do conteúdo de documentos formais. Deve-se notar, entretanto, que estes valores identificados geralmente representam apenas os valores manifestos da cultura, expressando o que as pessoas reportam ser a razão de seu comportamento, o que na maioria das vezes são idealizações ou racionalizações. As razões subjacentes ao seu comportamento permanecem escondidas ou inconscientes;

- Nível dos pressupostos inconscientes: são os pressupostos que determinam como os membros de um grupo percebem, pensam e sentem. À medida que certos valores compartilhados pelo grupo conduzem a determinados comportamentos, e estes comportamentos se mostram adequados para solucionar problemas, o valor é gradualmente transformado em pressuposto inconsciente. 
Segundo Chiavenato (2008), o conceito de cultura organizacional refere-se a um sistema de valores compartilhado pelos membros de uma organização, que a difere de outras organizações. Esse sistema pode ser definido como um conjunto de características que a organização valoriza. A cultura pode ser entendida como o conjunto de crenças e valores, costumes, tradições, conhecimentos e práticas de convívio social e relacionamento entre as pessoas. É representada pelo comportamento convencionado e aceito pela sociedade e provoca enorme influência e condicionamento sobre todas as ações e comportamentos das pessoas (ROBBINS, 2005). A cultura organizacional, por sua vez, influencia o clima organizacional, que consiste na atmosfera psicológica, no ambiente humano e em comportamentos observáveis existentes em uma organização. O clima pode se referir ao ambiente dentro de um departamento, de uma fábrica ou de uma organização inteira e influencia a motivação, o desempenho humano e a satisfação no trabalho.

Segundo Fleury e Fischer (2007), a cultura organizacional pode ser definida como a rede de concepções, normas e valores que são tomados por certos e permanecem submersos à vida organizacional. Para criar e manter a cultura, estas concepções, normas e valores devem ser afirmados e comunicados aos membros da organização de uma forma tangível. As formas tangíveis constituem os ritos, rituais, mitos, estórias, gestos e artefatos. O rito consiste em um conjunto planejado de atividades, relativamente elaborado, combinando formas de expressão cultural. Ao desempenhar um rito, as pessoas se expressam por meio de diversos símbolos: gestos, linguagem, comportamentos, artefatos, que evidenciam uma visão apropriada à ocasião. Beyer e Trice (1986) identificaram seis tipos de ritos organizacionais:

- Ritos de passagem - exemplo: processos de introdução e treinamento inicial;

- Ritos de degradação - exemplo: processos de demissão e substituição de um executivo;

- Ritos de confirmação - exemplo: seminários para reforçar a identidade da empresa;

- Ritos de reprodução - exemplo: processos de treinamento e reciclagem;

- Ritos para redução de conflito - exemplo: processo de negociação coletiva;

- Ritos de integração - exemplo: festas de fim de ano. 
Os ritos organizacionais são facilmente identificáveis, porém são de difícil interpretação. Beyer e Trice defendem que os gerentes devem desenvolver a habilidade de compreender e interpretar os ritos, visando administrar a cultura organizacional.

Segundo Hanna (1988), a cultura é, ao mesmo tempo, causa e efeito do comportamento organizacional. Os hábitos e as práticas de trabalho podem explicar como a organização realmente opera e os resultados que produz. Os valores e pressuposições são causa de determinados comportamentos, moldando prioridades e atitudes que, muitas vezes, exercem maior influência que a estratégia formal. Assim, o comportamento e os padrões de trabalho observáveis em uma organização, e ainda os valores e pressuposições implícitos que os causam, exercem influência crítica sobre os resultados da organização. Em outras palavras, os resultados provêm daquilo que as pessoas fazem na organização - tarefas, hábitos, normas, padrões e práticas. A cultura organizacional é, portanto, um fator crítico sobre o desempenho da organização, um fator chave que deve ser estudado e compreendido.

\subsubsection{Desempenho Organizacional}

Ao se comparar os resultados da organização com a situação do setor de atuação, observa-se a real performance da organização, ou seja, se o "contrato" entre a organização e o ambiente está sendo cumprido. Esta comparação dos resultados da organização requer a utilização de instrumentos de medida, chamados de indicadores de desempenho.

Para uma organização fazer frente à competição, é necessário criar mecanismos para saber se está realmente sendo competitiva e para verificar se está aperfeiçoando sua forma de atuação (MUSCAT e FLEURY, 1993). Deve-se, portanto, definir, medir e monitorar indicadores para avaliar e melhorar o desempenho competitivo. A escolha de quais indicadores medir e monitorar deve estar vinculada às decisões da estratégia competitiva da organização e de seus Fatores Críticos de Sucesso (FCS's). Inicialmente, devem ser identificados os atributos do produto mais valorizados pelos clientes. Estes atributos devem ser 
considerados ao se estabelecer a estratégia da organização, bem como na definição dos objetivos de desempenho a serem atingidos através da estratégia adotada. Identificados os atributos valorizados pelos clientes, a organização passa a conhecer seus FCS's, que "são variáveis nas quais a empresa precisa necessariamente ter bom desempenho para dar sustentação à estratégia competitiva". Uma vez apontados os FCS's, identificam-se as variáveis que devem ser mensuradas e, se possível, aperfeiçoadas. Desta forma, a cada FCS devem estar associados indicadores de gestão.

Ao se definir quais indicadores medir e monitorar, a organização deve estar consciente de quais atributos de seu produto são realmente valorizados pelos clientes. Segundo Slack (2002), os indicadores de desempenho devem estar associados aos objetivos de desempenho, que são classificados da seguinte forma:

- Objetivos ganhadores de pedidos - são aqueles que direta e significativamente contribuem para o ganho da organização, sendo vistos pelos consumidores como fatores chave de competitividade.

estabelecimento de indicadores para os objetivos ganhadores de pedido é essencial para monitorar o desempenho competitivo da organização;

- Objetivos qualificadores - não são os principais determinantes do sucesso competitivo da organização, mas são importantes de outro modo. São aqueles aspectos da competitividade nos quais o desempenho deve estar acima de determinado nível para que o cliente considere a organização como um possível fornecedor.

Segundo Hill (1993), para compreender o que é relevante para seu cliente, a organização deve saber identificar quais critérios são importantes para entrar e permanecer no mercado (qualificadores) e quais são essenciais para ganhar os pedidos dos clientes (ganhadores de pedidos).

Harrington (1991) argumenta que a medição é um ponto chave. Se não houver um sistema de indicadores, não é possível controlar; sem controle, é impossível gerenciar, e, se não houver gerenciamento, não é possível implantar melhorias. 
O conceito de aperfeiçoamento de processos tem sido amplamente estudado nas últimas décadas, envolvendo abordagens de breakthrough (ruptura), geralmente associadas a grandes mudanças para conseguir uma grande vantagem competitiva, e abordagens de obtenção de pequenas melhorias, associadas a ganhos gradativos e contínuos de desempenho.

A abordagem de melhoria contínua, também chamada por seu nome japonês kaizen, é uma abordagem evolutiva, incremental, que transfere aos funcionários de produção a responsabilidade pela qualidade, estabelecendo metas ambiciosas e incentivando a utilização das ferramentas da qualidade para buscar formas de melhorar gradativamente os processos existentes ao longo do tempo (CORRÊA e CORRÊA, 2009). Na abordagem de breakthrough, também conhecida por reengenharia, o objetivo é o redesenho radical dos processos para a obtenção de resultados drásticos e em prazos curtos. Esta abordagem, que "parte de uma folha em branco", é também mais arriscada. As duas abordagens podem ser encaradas como formas complementares de melhorar os processos, portanto não são mutuamente excludentes. Dependendo da situação, do desempenho alcançado com o processo atual, de mudanças na tecnologia existente no mercado, são necessários diferentes graus de radicalidade nas melhorias. A complementaridade das duas abordagens pode ser ilustrada pelo gráfico apresentado na Figura 2.10:

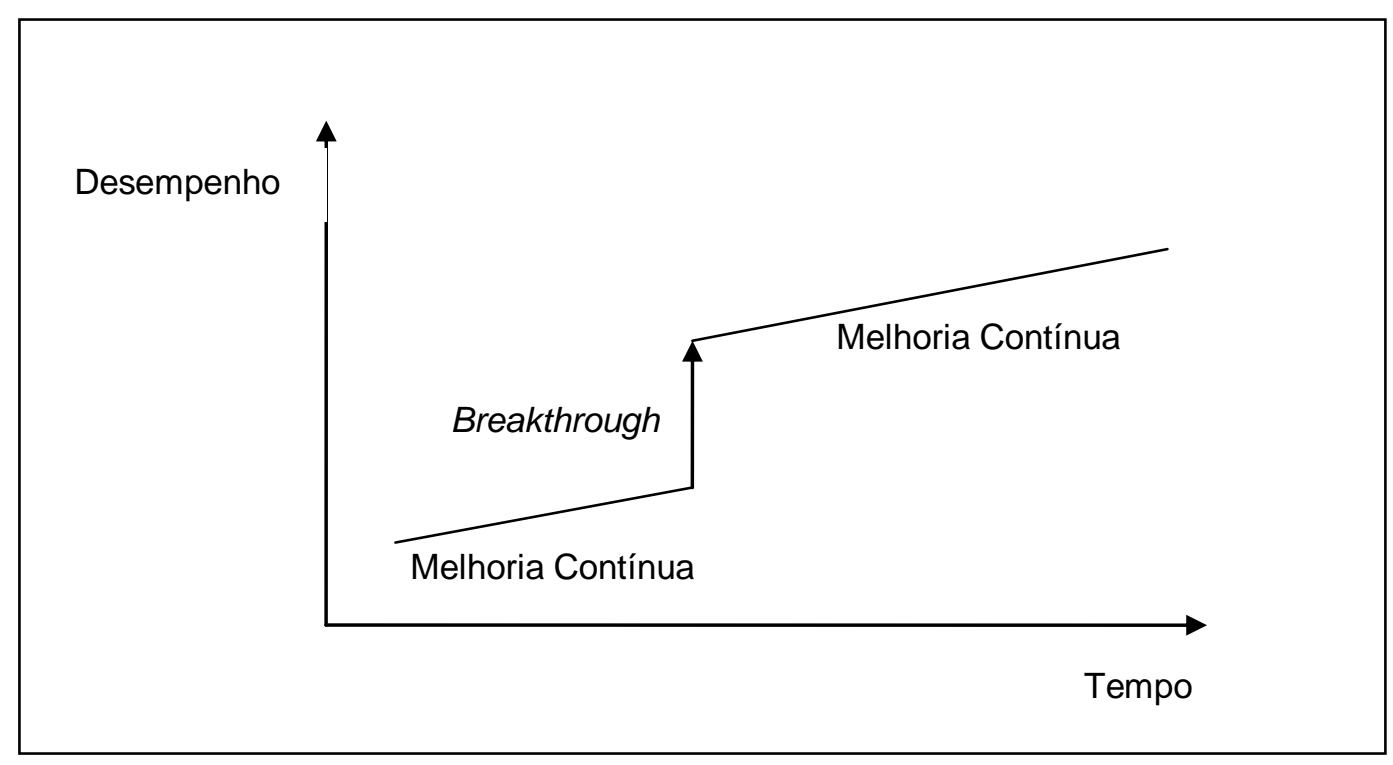

Figura 2.10 - Complementaridade das abordagens de melhoria contínua e breakthrough (adaptado de CORRÊA e CORRÊA, 2009) 
Vários termos são utilizados na literatura, como melhoria contínua, reengenharia, inovação, reestruturação ou redesenho de processos. O termo "aperfeiçoamento" será utilizado neste trabalho com um sentido amplo, englobando tanto padrões de breakthrough como de pequenas melhorias.

\subsection{As Instituições Públicas no Brasil}

Ao analisarmos a estrutura organizacional do setor público brasileiro de um modo geral, pode-se observar que uma das características mais evidentes é a grande departamentalização no modo de organização do trabalho. Esta condição, que chega a inspirar a denominação "repartição pública", tem origem histórica e está profundamente arraigada no setor. A estrutura apresenta hierarquias rígidas, com sistema de carreira baseado no mérito (concursos públicos), com ascensão na carreira a longo prazo. Os funcionários apresentam estabilidade empregatícia, sendo que a remuneração é baseada em tabela fixa de cargos e salários.

Os processos de trabalho são, tradicionalmente, baseados no modelo burocrático, ocorrendo muitas vezes um apego excessivo às normas, que passam a ser consideradas absolutas. Regras elaboradas para determinadas situações passam a ser gerais. Muitas vezes o trabalho passa a ser feito de certo modo simplesmente por "sempre ter sido feito assim", sem o questionamento da legislação, do "modus operandi", ou de outros aspectos envolvidos. É importante lembrar, porém, que, embora vista muitas vezes como obstáculo, a burocracia surge no setor público para minimizar o risco de desigualdade no tratamento dos cidadãos. Seu maior benefício é a manutenção do princípio da equidade. O compromisso com a conformidade no setor público é baseado na necessidade de se oferecer resultados imparciais a todos os indivíduos, um dos princípios da democracia.

Segundo Weber (2008), a burocracia é uma forma de organização que se baseia na racionalidade, isto é, na adequação dos meios aos objetivos pretendidos, a fim de garantir a máxima eficiência possível no alcance destes objetivos. Weber viu inúmeras vantagens para a utilização da burocracia, entre as quais se podem citar: 
- Racionalidade em relação ao alcance dos objetivos da organização;

- Precisão na definição do cargo e na operação, pelo conhecimento exato dos deveres;

- Rapidez nas decisões, pois cada um conhece o que deve ser feito, por quem deve ser feito e as ordens e papéis que tramitam através de canais preestabelecidos;

- Uniformidade de rotinas e procedimentos, que favorece a padronização, redução de custos e de erros, pois os procedimentos são definidos por escrito;

- Confiabilidade, pois o negócio é conduzido de acordo com regras conhecidas. As decisões são previsíveis e o processo decisório elimina a discriminação pessoal;

- Benefícios sob o prisma das pessoas na organização, pois a hierarquia é formalizada, o trabalho é dividido entre as pessoas de maneira ordenada, as pessoas são treinadas para se tornarem especialistas em seus campos. As pessoas podem fazer carreira na organização em função de seu mérito pessoal e competência técnica, entre outras.

A burocracia, no entanto, acaba trazendo consigo algumas disfunções ou consequências imprevistas:

- Internalização das regras e apego aos regulamentos;

- Excesso de formalismo e de papelório;

- Resistência a mudanças;

- Despersonalização do relacionamento;

- Categorização como base do processo decisório;

- Superconformidade às rotinas e aos procedimentos;

- Exibição de sinais de autoridade;

- Dificuldade no atendimento a clientes e conflitos com o público.

Outra característica peculiar do setor público brasileiro é a sua cultura. Apesar da história da administração pública no Brasil ter menos de 500 anos, ela apresenta um modus operandi próprio (CARBONE, 2000). Uma pesquisa realizada em 
secretarias de governo levantou práticas características de gerentes públicos, mostrando como o contexto sócio-cultural brasileiro condiciona a ação de ocupantes de posições de chefia (JUNQUILHO, 2004). Entre as práticas, destacam-se:

- O sincretismo entre a pessoalidade e a impessoalidade - as amizades e a proximidade social, cultivada entre colegas de trabalho, podem ser utilizadas para facilitar o alcance de objetivos e o cumprimento de tarefas por parte dos subordinados. Esta prática, contudo, dificulta a aplicação de regras formais. Cabe ao gerente ter a habilidade de conciliar o convívio informal com a legislação formal, atendendo conflitos entre interesses legais e pessoais;

- O comportamento centralizador - ao mesmo tempo em que age com afeto em relação aos subordinados, o gerente usa da hierarquia e da autoridade formal para agir com rigor em relação a um desafeto ou promover a centralização de informações ou decisões, dificultando uma configuração mais sistêmica e integrada. Sua liderança é construída por meio de um misto entre carisma e autoridade formal;

- A habilidade para contornar o "formalismo" - através de contatos informais ou utilização de procedimentos "criativos";

- Aversão a controles formalizados - prática de não realizar avaliações formais de desempenhos individuais ou coletivos, ou seja, dificilmente são medidos metas e alcance de resultados.

Existem outras características do setor público que exercem influência sobre seu desenho organizacional (McADAM e DONAGHY, 1999), podendo-se citar:

- Mudanças de direção política periódica, podendo ser drásticas;

- Interesses políticos, geralmente enfatizando mudanças de curto prazo;

- Sobreposição de iniciativas, muitas vezes criadas em períodos políticos diferentes.

As evidências sugerem que, se não se considerar a estrutura, a burocracia, o ambiente político de organizações públicas e outras características específicas do setor, iniciativas de mudança organizacional podem vir a falhar. Nas últimas 
décadas, porém, o setor público de um modo geral viu-se sob maior pressão para melhorar seu desempenho e demonstrar maior transparência e avaliação de resultados (accountability), o que resultou na busca de melhorias em sua forma de operar. Várias estratégias de mudança têm sido adotadas por diferentes instituições públicas, geralmente utilizando práticas gerenciais do setor privado. O movimento que defende a adoção de práticas do setor privado no setor público ficou conhecido como Nova Gestão Pública (NGP) ou New Public Management (NPM). A NGP é caracterizada por apresentar maior foco em resultados em termos de eficiência e eficácia, foco no cliente/cidadão (interessado) e substituição de uma estrutura hierárquica e altamente centralizada por uma gestão menos centralizada, onde as decisões sobre alocação de recursos e entrega de serviços são realizadas mais próximas do ponto de entrega, o que permite maior feedback dos clientes e de grupos interessados. A NGP engloba os seguintes princípios (HOOD, 1991):

- Adoção de gestão profissional;

- Adoção de padrões explícitos e medidas de desempenho;

- Maior ênfase no controle de resultados;

- Aumento na descentralização de unidades do setor público;

- Aumento da competição no setor público;

- Ênfase em práticas de gerenciamento do setor privado;

- Maior disciplina e parcimônia na utilização de recursos.

Estas doutrinas representam as manifestações mais típicas da NGP. Os conceitos da NGP passaram a ser bastante difundidos por Osborne e Gaebler (1992) e atualmente têm alcance mundial. Assim como no setor privado, a NGP envolve práticas como downsizing, reengenharia, desenvolvimento de responsabilidade gerencial e gestão da qualidade total (TQM). Como resultado da adoção destas práticas, espera-se obter aumento na avaliação de resultados, maior transparência e maior eficiência no setor público. Os conceitos da NGP podem ser mais explicitados por meio dos "5 R's" (JONES e THOMPSON, 2000) Reestruturação, Reengenharia, Reinvenção, Realinhamento e Reconceitualização. O Quadro 2.6 apresenta um resumo dos principais conceitos envolvidos nos " 5 R's": 
Quadro 2.6 - Os cinco "R's" da Nova Gerência Pública

\begin{tabular}{|c|c|}
\hline 1. Reestruturação & $\begin{array}{l}\text { - Identificar as competências centrais da organização } \\
\text { - Eliminar da organização tudo aquilo que não agregue valor a seus } \\
\text { serviços, especialmente as regras que inibem o desempenho } \\
\text { - Contratar externamente tudo aquilo que não seja uma competência central } \\
\text { da organização } \\
\text { Ferramentas: TQM, análises da cadeia de valor, estimativas de custos } \\
\text { baseadas nas atividades (ABC). }\end{array}$ \\
\hline 2. Reengenharia & $\begin{array}{l}\text { - Iniciar novamente, em vez de tentar "ajeitar" os processos existentes } \\
\text { - Colocar a informatização e outras tecnologias da informação no centro das } \\
\text { operações } \\
\text { - Construir da base em direção ao topo, em vez de fazê-lo de cima para } \\
\text { baixo } \\
\text { - Basear o desenho organizacional mais em processos que em funções e } \\
\text { posições no organograma } \\
\text { - Enfocar o esforço na melhoria da qualidade do serviço e na redução do } \\
\text { tempo de ciclo produtivo e dos custos } \\
\text { Ferramentas: modernas bases de dados, sistemas especializados e } \\
\text { tecnologias da informação, trabalho em equipe, benchmarking e otimização } \\
\text { do tempo do ciclo produtivo. }\end{array}$ \\
\hline 3. Reinv & $\begin{array}{l}\text { - Desenvolver um processo de planejamento } \\
\text { - Estabelecer uma estratégia de serviço e de mercado } \\
\text { - Deslocar a organização em direção a novas modalidades de fornecimento } \\
\text { de serviços e novos mercados } \\
\text { Ferramentas: planejamento estratégico, pesquisas de mercado, } \\
\text { determinação de custos de metas, redes e alianças. }\end{array}$ \\
\hline 4. Realinhamento & $\begin{array}{l}\text { - Alinhar as estruturas administrativas e de responsabilidade da organização } \\
\text { com suas estratégias de mercado e de fornecimento de serviços } \\
\text { - Alinhar a estrutura de controle/recompensas da organização com suas } \\
\text { estruturas administrativas e de responsabilidades } \\
\text { - Priorizar os centros de missão; se as unidades não desempenharem } \\
\text { missões centrais, devem ser consideradas unidades de apoio } \\
\text { Ferramentas: organizações baseadas no desempenho, estruturas } \\
\text { multidivisionais, produção mínima, orçamento e prestação de contas das } \\
\text { responsabilidades, preços de transferência, incentivos de alto poder. }\end{array}$ \\
\hline 5. Reco & $\begin{array}{l}\text { - Acelerar o ciclo de observação, orientação, decisão e ação - tanto para } \\
\text { melhorar o desempenho quanto para aprender mais rapidamente } \\
\text { - Capacitar os trabalhadores da linha de frente para avaliar o desempenho } \\
\text { do serviço e oferecer um feedback sobre o fornecimento do serviço e da } \\
\text { estratégia } \\
\text { - Construir uma organização com capacidade para aprender e para se } \\
\text { adaptar } \\
\text { Ferramentas: descentralização, controles flexíveis, capital de trabalho, } \\
\text { análise rápida, novos modelos de aprendizagem. }\end{array}$ \\
\hline
\end{tabular}

Fonte: Jones e Thompson (2000)

A literatura apresenta inúmeros casos de implantação da NGP em vários países, entre eles Reino Unido, Nova Zelândia, Austrália, Alemanha, Suíça, Estados Unidos, Itália, Brasil e Etiópia (HORTON, 2003; GAULD, 2003; BROWN; WATERHOUSE e FLYNN, 2003; GRUENING, 2001; EMERY e GIAUQUE, 2003; GULLEDGE Jr. e SOMMER, 2002; ONGARO, 2004; CUNHA, 2002; HOPE, 2001). 
Na maioria dos artigos, porém, a abordagem utilizada enfatiza muito mais questões de ordem política, não havendo uma descrição mais detalhada da forma de operacionalização das mudanças. É certo que a NGP engloba mudanças de ordem muito mais ampla que o desenho organizacional, uma vez que abrange aspectos da reforma administrativa de um modo geral, chegando inclusive a questionar o conceito da "coisa" pública. Entretanto, é inegável que a abordagem do desenho organizacional tem muito a oferecer para a reforma no setor público, uma vez que proporciona uma visão integrada das diversas dimensões que compõem uma organização, com orientação para o cliente/cidadão (ONGARO, 2004; GULLEDGE e SOMMER, 2002). Deve-se notar, ainda, que existem várias características específicas do setor público que exercem influência sobre seu desenho organizacional, como a existência de leis específicas, hierarquias rígidas e a própria cultura do setor. Estas características evidenciam a necessidade de se adotar desenhos organizacionais específicos para o setor público, ao invés de simplesmente serem aplicados modelos desenvolvidos para o setor privado.

Entre os trabalhos acadêmicos sobre setor público encontrados, pode-se citar o programa de melhoria proposto por McAdam e Donaghy (1999). Estes autores, ao investigarem os fatores críticos de sucesso para a implantação de um programa de reengenharia de processos em uma organização do setor público no Reino Unido, avaliam as características específicas deste setor que influenciam a aplicação de programas de melhoria. Outro trabalho apresentado na literatura é o de Greasley (2004), que propõe um modelo estruturado de melhoria de processos aplicado em um programa de melhoria no setor de recursos humanos da polícia do Reino Unido. A metodologia apresentada combina técnicas estabelecidas, como Balanced Scorecard (BSC) e mapeamento de processos com um sistema de scoring para priorizar os processos. Segundo o autor, a metodologia assegura que os processos corretos serão identificados e redesenhados no nível operacional, de forma a sustentar os objetivos estratégicos da organização. Além disso, a metodologia utiliza sistemas de medidas de desempenho para verificar se as mudanças implantadas realmente alcançam o efeito desejado ao longo do tempo.

No Brasil, a mudança organizacional na administração pública tem sido discutida desde a década de 1940. A reforma administrativa no setor público brasileiro era baseada em uma atitude clássica e universalista, que admitia existir 
uma maneira certa ou excelente de organizar, bastando ter o conhecimento dos princípios administrativos para que se pudesse administrar qualquer organização. Esta perspectiva de uma única forma de organizar, no entanto, foi eliminada com a adoção da abordagem contingencial. O contingencialismo passou a ser adotado gradativamente em projetos de mudança organizacional no setor público brasileiro, podendo-se exemplificar o caso descrito por Hernandez Filho e Felicíssimo (1981) que objetivava a modernização do Ministério da Agricultura. $O$ desenho de uma organização depende não só de diversos fatores, como também das inúmeras formas como esses fatores possam vir a combinar-se. A adoção de uma abordagem contingencial no programa de modernização do Ministério da Agricultura é percebida ao se observar que não se pretende oferecer ao Ministério um modelo organizacional adequado, mas sim um modelo para a organização saber lidar com a própria mudança, saber buscar soluções satisfatórias em uma sucessão de contínuos aperfeiçoamentos, capacitando os membros da organização, através de um processo educacional, a darem continuidade ao programa. Outro aspecto que deve ser mencionado neste caso é a abordagem sistêmica que se buscou dar ao programa de modernização. O modelo de reforma administrativa adotado tradicionalmente em organizações do setor público brasileiro baseava-se principalmente na ação sobre setores isolados. No caso descrito, objetivava-se o "desenvolvimento da organização como um todo, tornando-a altamente adaptativa às mudanças sociais e tecnológicas, integrando as necessidades humanas às metas organizacionais e aumentando sua eficácia na interação com o ambiente".

Desde a década de 1990, buscou-se construir organizações públicas no Brasil orientadas para o cidadão, considerando sua condição de destinatário das ações e dos serviços prestados e ainda sua posição como mantenedor do Estado. Com o intuito de se atingir este objetivo, foi criado, dentro do contexto do Programa Brasileiro de Qualidade e Produtividade - PBQP - o Sub-Programa de Qualidade e Produtividade na Administração Pública, visando tornar os órgãos e entidades públicos mais eficientes na administração dos recursos públicos e mais voltados para o atendimento às demandas da sociedade. Quatro programas caracterizam a evolução desse movimento pela qualidade no setor público brasileiro (Cadernos GESPÚBLICA, 2006): 
- Sub-Programa da Qualidade e Produtividade na Administração Pública criado em 1990, apresenta uma abordagem voltada para a gestão de processos;

- QPAP - Programa da Qualidade e Participação na Administração Pública criado em 1996, com abordagem orientada para resultados;

- PQSP - Programa da Qualidade no Serviço Público - criado em 2000, enfatizando a qualidade do atendimento ao cidadão;

- GESPÚBLICA - Programa Nacional de Gestão Pública e Desburocratização criado em 2005, com ênfase na gestão por resultados orientada para o cidadão.

Deve-se notar que os quatro programas não representam rupturas, mas constituem incrementos a partir da concepção inicial.

No Brasil, a NGP passou a ser difundida a partir de 1995, durante um processo amplo de reestruturação do Estado. Bresser-Pereira (1996) definiu a reestruturação administrativa como uma das respostas à crise econômica, política, fiscal e burocrática. A reforma administrativa se fazia necessária, pois o modelo burocrático de gestão estatal havia se tornado caro, lento e incapaz de atender às crescentes demandas sociais. Sua proposta foi a concepção de uma série de estratégias que passaram a ser denominadas administração pública gerencial. A administração pública gerencial propõe a substituição de "administradores públicos" por "novos gerentes", pressupondo a mudança dos chamados valores burocráticos pelos gerenciais. Existem autores que relatam casos de implantação da NGP no setor público brasileiro, como Cunha (2002), que descreve um projeto piloto na Prefeitura Municipal de Curitiba, junto à Secretaria Municipal de Educação. A ênfase deste projeto piloto, no entanto, é na esfera estratégica, com objetivos como desenvolvimento de missão, visão, objetivos estratégicos, metas e metodologias de controle e avaliação, e não há muita preocupação com uma abordagem de desenho organizacional ou com o aperfeiçoamento do mesmo. Outros autores preocupam-se com os desafios a serem enfrentados na perspectiva de pessoal e de mudança cultural no setor público, devido às novas tendências da NGP (JUNQUILHO, 2004; CARBONE, 2000). No setor de saúde, existem inúmeras iniciativas na área de melhoria da qualidade, como descrevem Macedo-Soares e Santos (2001). Com 
base em uma pesquisa realizada com 21 hospitais, estes autores chegam a propor um modelo para auxiliar na implantação de estratégias de qualidade orientadas para o cidadão.

A abordagem de intervenção organizacional no setor público brasileiro também sofreu alterações. Caracterizadas inicialmente pelo estilo impositivo, pelo isolamento do grupo responsável pela reforma e pelo escopo imediatista, evoluiu para técnicas mais flexíveis, em que o interventor assume o papel de facilitador, analista, catalisador e auxiliar num processo de aprendizagem. Gonçalves et al (1996) descrevem a utilização da metodologia da pesquisa-ação pela FUNDAP Fundação do Desenvolvimento Administrativo - em organizações públicas brasileiras, ao longo de vinte anos de projetos de consultoria. A pesquisa-ação, por ser não-prescritiva, é capaz de enfrentar, a partir de sucessivas adaptações, os constantes desafios provocados por mutações no ambiente político e institucional e ainda ser coerente com os novos paradigmas de gestão organizacional. A técnica permite a constante aprendizagem através da prática e da experimentação em um processo contínuo e cíclico, além de promover a participação tanto do consultor como do cliente nas decisões, possibilitando o comprometimento nas ações.

Gonçalves et al (1996) descrevem alguns casos executados pela FUNDAP ao longo de vinte anos em organizações públicas brasileiras: Consultoria organizacional à Pinacoteca do Estado, órgão vinculado à Secretaria da Cultura do Estado de São Paulo; Consultoria organizacional ao Instituto do Açúcar e do Álcool, uma autarquia vinculada ao Ministério da Indústria e do Comércio; Consultoria para a formulação da Política Estadual de Recursos Hídricos em São Paulo; e Consultoria organizacional à Secretaria da Saúde de São Paulo. Ao longo dos casos, foram identificadas três fases no processo de aprendizagem da FUNDAP nas intervenções consultivas. Na primeira fase, a pesquisa-ação ocorreu em um ambiente político caracterizado pela centralização e estatização. A intervenção, nessa fase, caracterizou-se por uma abordagem sócio-técnica, sendo que os interventores tinham a função de conduzir as mudanças. A visão de organizações como sistemas sócio-técnicos pode ampliar muito os horizontes durante reformas administrativas no setor público, uma vez que reconhece que além da tecnologia presente nas tarefas, as organizações são formadas por relações sociais, ou seja, relações entre indivíduos e grupos. A segunda fase surgiu quando a abordagem sócio-técnica deixou de dar conta da 
complexidade de mudanças em um ambiente não mais orientado pela centralização e estatização, mas pela necessidade de articulação de alianças para se conseguir mudanças negociadas. Esta segunda fase caracterizou-se pela abordagem técnicopolítica, sendo que o papel dos interventores era o de facilitar a mudança. A terceira fase da aprendizagem da FUNDAP na área consultiva organizacional no setor público caracterizou-se por um ambiente político de desregulação e privatização, em que a iniciativa de ação deixa de ser do Estado, que passa a desempenhar papel de sinalizador das trajetórias de investimento e desenvolvimento socioeconômico. A abordagem da intervenção, nesta fase, passou a ser sócio-política.

Outro aspecto analisado por Gonçalves, Pinto e Barreto (1987) diz respeito à estrutura de poder dentro de uma organização pública. Estes autores lembram que o processo de construção da decisão na administração pública muitas vezes sofre influências de "anéis" de interesses específicos e transitórios, formados por grupos que circundam a pessoa que ocupa um cargo de poder público, conceito lançado por Cardoso (1975).

As abordagens que vêm sendo introduzidas na análise e elaboração do desenho organizacional e de estratégias de mudança organizacional ainda não foram objeto de avaliação ampla e sistemática no Brasil. Contudo, tanto sua aplicação no exterior (considerando-se sua flexibilidade para adaptação a realidades diferenciadas), quanto a comparação com teorias e métodos clássicos, sugerem que novos trabalhos devem ser elaborados, especialmente a partir dos conceitos da teoria dos sistemas. A instrumentação da reforma administrativa em nosso país poderá sofrer ainda muitas alterações e enriquecer-se pela incorporação de novas perspectivas teóricas, entre as quais se destaca o conceito de sistema aberto, a visão das organizações como sistemas sócio-técnicos e métodos de intervenção baseados em processos de aprendizagem.

\subsection{Teoria dos Sistemas}

A ciência moderna é caracterizada por uma crescente especialização, determinada pela enorme soma de dados e pela complexidade das técnicas e das estruturas teóricas de cada campo. Desta forma, a ciência acabou sendo dividida em 
inúmeras disciplinas que geram continuamente novas subdisciplinas e tornam cada campo de estudo um universo encapsulado. Em oposição a este modo de conceber a ciência, surgiu a teoria dos sistemas (BERTALANFFY, 1977; BERTALANFFY, 2009), que enfatiza a necessidade de estudar não somente partes e processos isoladamente, mas também de resolver os decisivos problemas encontrados na organização e na ordem que os unifica, resultante da interação dinâmica das partes, tornando o comportamento das partes diferente quando estudado isoladamente e quando tratado no todo. Os trabalhos de Ludwig von Bertalanffy sobre a teoria geral dos sistemas tiveram grande influência nas diversas áreas da ciência, desde a física, a biologia e a química, até a psicologia e as ciências sociais.

O enfoque de sistemas traz várias contribuições de interesse para a área de produção, tais como a visão ampla na solução de problemas, ao invés de uma visão restrita, e a consideração de interdependências. No âmbito das organizações, busca-se estudar as empresas como sistemas, com entradas e saídas mensuráveis, que exigem controles e medidas. Busca-se a compreensão da organização como um todo, de seus mecanismos internos e do seu ambiente, com o propósito de aprimorá-la do ponto de vista físico e de sua gestão. Entre os autores que merecem destaque, pode-se citar (MUSCAT, 1993):

- Emery e Trist - com trabalhos realizados na década de 1960, preocupam-se com os aspectos de interdependência, discutindo a transformação da tecnologia de gestão, aspectos de integração física e a influência exercida e sofrida pela organização com relação ao ambiente. Do enfoque sistêmico, a organização revela-se como um conjunto de pelo menos dois sistemas (ou subsistemas) que se influenciam mutuamente: o sistema técnico, formado por recursos e componentes físicos e abstratos, como objetivos, divisão do trabalho, tecnologia, instalações, procedimentos; e o sistema social, formado por todas as manifestações de comportamento dos indivíduos e dos grupos, como relações sociais, grupos informais, cultura, clima, atitudes e motivação (EMERY, 1969). Este enfoque, chamado sócio-técnico, considera que é impossível gerenciar um sistema sem levar em conta o outro;

- Churchman - cujos trabalhos, da década de 1970, apresentam a formulação de um conjunto de características inerentes a um sistema: objetivos, componentes, ambiente, recursos e administração. O autor também 
apresenta as categorias denominadas cliente do sistema, tomador de decisões e projetista do sistema (CHURCHMAN, 1973);

- Ackoff - em seu trabalho de 1981 é apresentado o conceito de stakeholder, um indivíduo ou instituição que apresenta interesse no sistema, incluindo tanto interessados internos como externos à organização. Para este autor, o objetivo da empresa consiste em atender a todos os grupos interessados, através do aumento da sua capacidade em atingir os seus objetivos mais eficiente e eficazmente (ACKOFF, 1981).

A contribuição humana ao processo de trabalho também deve ser estudada e otimizada. Os projetos de processos inovadores não podem deixar de lado a criatividade e a autonomia do trabalhador. O trabalho deve ser projetado como um sistema "soft", humano, e não como um sistema mecânico rígido. Neste sentido, os trabalhos de Checkland e Scholes (1999) consistem em um marco na história do movimento dos sistemas (ZEXIAN e XUHUI, 2010). Segundo Checkland e Scholes (1999), partindo da premissa de que as organizações são sistemas abertos que interagem com o ambiente, devem-se incluir como parte desses sistemas os subsistemas de atividade humana. A Soft Systems Methodology (SSM), desenvolvida por estes autores, auxilia a lidar com situações complexas do mundo real, e parte do princípio de que um sistema deve ser observado incorporando impressões tanto objetivas como subjetivas, incluindo as pessoas envolvidas, as áreas problema, origens de conflito e outros aspectos "soff" do sistema.

A teoria dos sistemas apresentou vários desdobramentos nas diversas áreas da ciência, inclusive no estudo das organizações e de sistemas complexos, podendo-se citar os trabalhos de Sterman (2000), Stacey (2000), Haines (2000), Morecroft, Sanchez e Heene (2002), Hitchins (2003), Hammond (2003), Gharajedaghi (2006) e Boardman e Sauser (2008).

O conceito de sistema aberto, desenvolvido inicialmente para sistemas biológicos, é perfeitamente aplicável à organização empresarial (CHIAVENATO, 2011). O enfoque sistêmico enfatiza o ambiente no qual a organização está inserida. A visão dos sistemas abertos sugere que sempre se deve ter em vista o ambiente, buscando compreender as interações organizacionais diretas com clientes, concorrentes, fornecedores, sindicatos, agências governamentais, etc., bem como o contexto mais amplo do ambiente geral. Uma organização, como um sistema aberto, 
está em um processo contínuo de troca com seu ambiente, sendo essa troca crucial para a vida e a forma do sistema, é caracterizada por um contínuo de entrada, de transformação interna, saída e retroalimentação.

Um segundo aspecto do enfoque dos sistemas abertos é aquele que define uma organização em termos de subsistemas inter-relacionados. As organizações são formadas por indivíduos (que são sistemas em si mesmos), que pertencem a grupos ou departamentos, que também pertencem a divisões organizacionais maiores, e assim por diante. Se a organização é definida como um sistema, então os outros níveis podem ser compreendidos como subsistemas, exatamente como em um organismo vivo. Uma contribuição particularmente interessante nesse sentido foi apresentada por Almeida (1981), que propôs um modelo de sistema produtivo considerando o vínculo tecnológico existente entre os vários subsistemas que o compõem. Segundo este autor, um sistema produtivo é composto por vários subsistemas, por exemplo, subsistemas de Pesquisa, de Engenharia (Projeto), de Fabricação, de Consumo, etc., que apresentam vínculos e interagem entre si. Ao apresentar os conceitos de um sistema de produção, Muscat (1993) também considera que um sistema produtivo é formado por vários subsistemas. No modelo proposto por este autor, o sistema produtivo é composto pelo subsistema de produção (fabricação), assim como por outros subsistemas, como o logístico, o de engenharia e o de pesquisa e desenvolvimento. Pode-se considerar, por sua vez, que estes subsistemas são formados por outros dois subsistemas: subsistema físico e subsistema de gestão. Os subsistemas físicos realizam as operações produtivas propriamente ditas dos sistemas de produção, logístico, de engenharia e de P\&D. Tais subsistemas empregam recursos produtivos (materiais, mão de obra, equipamentos e instalações, informações, serviços, energia, etc.), realizam as operações (interações entre os recursos produtivos) e geram produtos (bens e/ou serviços) assim como outras saídas (refugos, poluição, subprodutos, etc.). Os produtos atendem às necessidades de clientes. Os clientes podem participar ativamente ou não das operações que criam o produto. O subsistema de gestão toma decisões com relação às operações realizadas pelo subsistema físico contido no mesmo subsistema anterior. Além disso, o subsistema de gestão tem o papel de monitorar e controlar a atuação do subsistema físico. Finalmente, cabe também ao subsistema de gestão a função de interligação com os outros sistemas em 
consideração. Caso se considere a gestão do sistema de produção, ela deve realizar a interligação com a engenharia, a P\&D, o sistema logístico e o ambiente.

O sistema aberto, portanto, se caracteriza por um intercâmbio de transações com o ambiente e conserva-se constantemente no mesmo estado (autorregulação), apesar de a matéria e a energia que o integram se renovarem constantemente (equilíbrio dinâmico ou homeostase) (MILLER, 1965). Neste ponto, é fundamental compreender o conceito de equilíbrio dinâmico decorrente desta forma de visualizar uma organização. O conceito de equilíbrio dinâmico, também chamado de homeostase, diz respeito à autorregulação e à capacidade de conservar um estado equilibrado (MORGAN, 1996). Em analogia com os organismos biológicos, o processo de homeostasia regula e controla o funcionamento do sistema, com base na chamada "retroalimentação negativa", segundo a qual um desvio da normalidade engendra ações destinadas a corrigi-lo. Assim como o corpo humano com temperatura elevada desencadeia ações no sentido de contra-atacar esta situação, os sistemas organizacionais também têm necessidade de tais processos de controle homeostático, caso queiram conservar-se de forma estável. A necessidade de considerar os equilíbrios dinâmicos ao projetar uma organização também foi abordada por Nadler et al (1994), que enfatizam que as organizações apresentam características de sistemas abertos, como interdependências internas, capacidade de feedback, equilíbrio, equifinalidade e adaptação.

\subsection{Análise Crítica da Literatura}

Considerando que esta pesquisa foca o desenho organizacional de uma organização pública do setor de semicondutores, ao revisar a literatura acadêmica, foram buscados trabalhos específicos sobre desenho organizacional e/ou suas cinco dimensões, conforme o modelo de Galbraith (2009). O modelo de Galbraith foi selecionado como base para a presente pesquisa, por englobar, do ponto de vista da autora, vários aspectos apresentados pelos demais autores estudados.

São inúmeros os trabalhos sobre desenho organizacional e suas dimensões desenvolvidos para empresas do setor privado, incluindo os próprios trabalhos de Galbraith (2009), que aplica o modelo da estrela na revisão do desenho 
organizacional de empresas privadas de vários setores. Os trabalhos sobre desenho organizacional no setor de semicondutores, no entanto, são mais escassos. Alguns autores conduziram pesquisas em empresas privadas deste setor, estudando aspectos relacionados à dimensão pessoas (OOI et al, 2007). Questiona-se, porém, se as práticas do setor privado são realmente adequadas ao ambiente do setor público. Há evidências que sugerem que, se não se considerar a burocracia e o ambiente político de organizações públicas, iniciativas de mudança ou melhoria tendem a falhar.

Analisando a literatura acadêmica sobre desenho organizacional no setor público, observa-se que os pesquisadores geralmente focam as diferentes dimensões do desenho organizacional individualmente, ao invés de analisarem as dimensões de uma forma integrada e interdependente. Há trabalhos relacionados à dimensão estratégia (McADAM, WALKER e HAZLETT, 2011), à dimensão pessoas (VIGODA-GADOT, 2006; BELLOU, 2009; GRÖENEVELD, 2011; TROSHANI e JERRAM, 2011), à dimensão processos (HELLSTRÖM e PETERSON, 2006) e à dimensão estrutura organizacional (MALLAK e WATTS, 1997; OTHMAN e SAID, 2007; RYAN, 2008; ALDAMA, AMAR e TROSTIANKI, 2009). Alguns autores focam a questão da cultura organizacional do setor público (SCHRAEDER, TEARS e JORDAN, 2005) e a gestão de custos para obtenção de melhores resultados (VERBEETEN, 2011; LUKE, KEARINS e VERREYNNE, 2011). A literatura acadêmica sobre o setor público brasileiro é ainda mais escassa, também focando, geralmente, nas dimensões do desenho organizacional de forma individual. Há trabalhos que estudam a dimensão pessoas (JACKSON FILHO, 2004; BAHRY e TOLFO, 2007; ROCHA e SILVA, 2007; UBEDA e SANTOS, 2008; VILLARDI, FERRAZ e DUBEUX, 2011) e a dimensão processos (RUTKOWSKI, 1998; VAZ e LOTTA, 2011), além de se encontrarem estudos sobre a questão da utilização da tecnologia da informação no setor público (BECKER, LUNARDI e MAÇADA, 2003; LEITE e REZENDE, 2010), bem como sobre a estrutura e modelos de governança e gestão (FONTES FILHO e PICOLIN, 2008; LOPES e BALDI, 2009; SECCHI, 2009; GARCIA e SALLES FILHO, 2009). Alguns trabalhos buscam integrar mais de uma dimensão, como no caso de Costa, Salles e Fontes Filho (2010), que associam a dimensão estratégia com o sistema de recompensas, e o trabalho de Brandão et al (2008), que integra a dimensão estratégia com a dimensão pessoas. 
Considerando a revisão bibliográfica realizada, podem ser levantadas algumas limitações:

- Vários trabalhos consideram apenas uma dimensão do desenho organizacional, dando menor atenção às demais dimensões e à integração e alinhamento entre as dimensões;

- Existe menor atenção à modelagem e análise do ambiente em que a organização em estudo está inserida;

- Os trabalhos desenvolvidos especificamente para o setor público são relativamente escassos, sendo que muitas vezes práticas do setor privado são aplicadas sem as adaptações necessárias;

- São raros os modelos desenvolvidos no contexto do setor de semicondutores.

Em vista das limitações acima descritas, a autora considera que é fundamental a construção de um desenho organizacional em que todas as dimensões - estratégia, pessoas, sistemas de recompensa, processos (incluindo aplicações de $\mathrm{TI}$ ) e estrutura organizacional - estejam alinhados entre si e com o ambiente em que a organização atua. Mais do que isso, é necessário compreender que todas estas dimensões são interdependentes e encontram-se em equilíbrio dinâmico entre si e com o ambiente. A Figura 2.11 apresenta o modelo da estrela, representando também os vários equilíbrios existentes entre as dimensões do desenho organizacional e entre estas e o ambiente: 


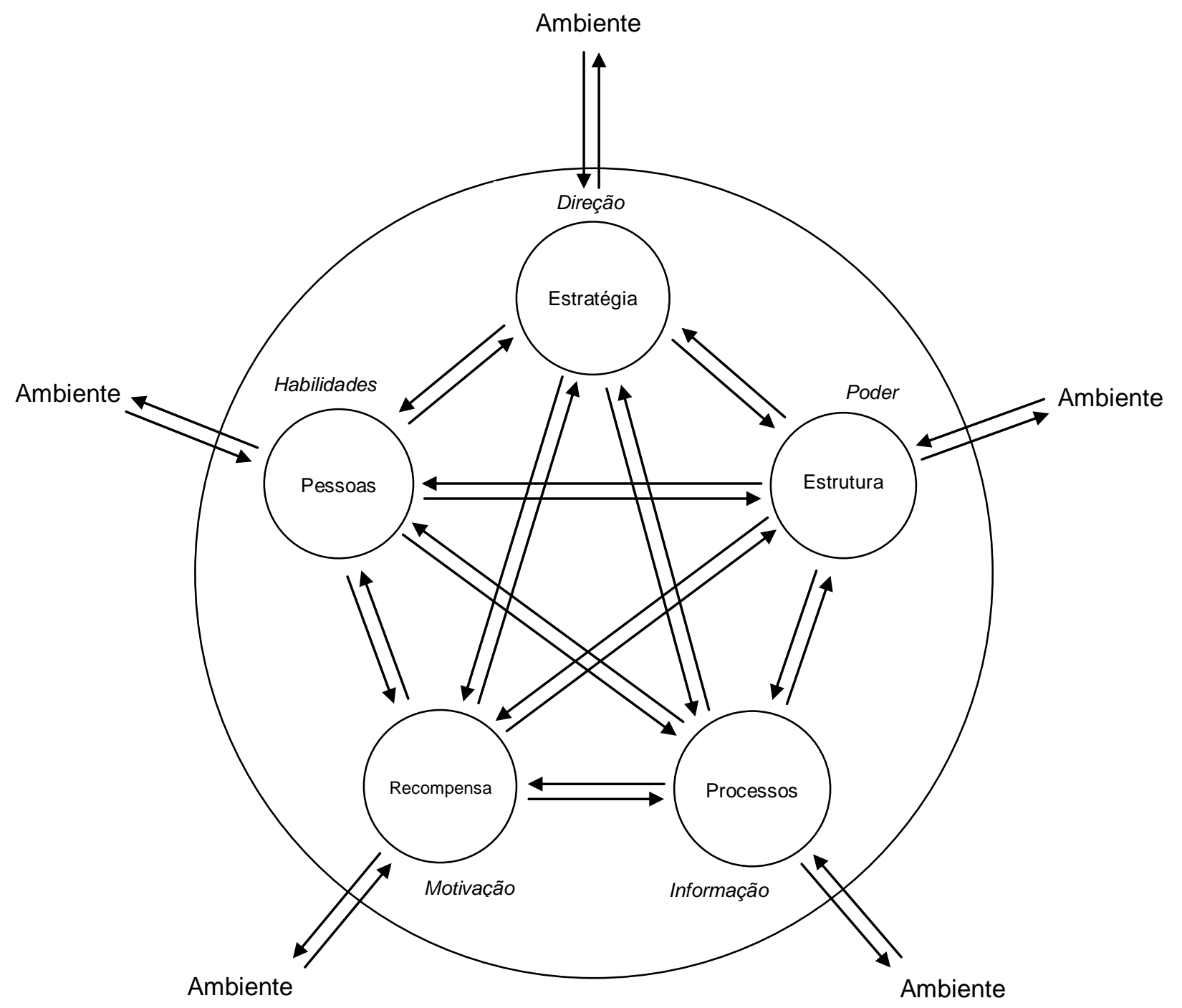

$\longleftrightarrow$ Equilíbrio dinâmico

Figura 2.11 - Equilíbrios Dinâmicos do Desenho Organizacional Elaborado pela autora, adaptado de Galbraith (2009)

Ao se construir o desenho organizacional, é fundamental identificar e compreender os diversos aspectos (variáveis) que influenciam e alteram tais equilíbrios entre as dimensões, de forma que, ao longo da existência da organização, esta possa gerenciá-los para que se mantenha o alinhamento interno entre todas as dimensões e entre as dimensões e o ambiente. No caso a ser 
estudado, o desenho organizacional deve considerar as características específicas do setor público, como a existência de hierarquias rígidas, a cultura do setor, a estabilidade dos funcionários, múltiplos stakeholders para muitos processos, possibilidade de mudanças de direção, existência de interesses políticos, amplo escopo de atividades, entre outras. Além disso, deve considerar a missão da organização criada, incluindo os objetivos de fomentar o desenvolvimento do setor de microeletrônica no Brasil e de formar recursos humanos específicos para este setor.

O grande desafio para a administração atual consiste em obter uma compreensão clara e profunda das organizações em sua totalidade, de seu funcionamento e de como gerenciá-las de uma forma sistêmica. Esta compreensão depende do conhecimento de características particulares do desenho organizacional de cada organização. A iniciativa do governo federal de criar uma empresa de semicondutores proporciona uma oportunidade ímpar para se desenvolver tais pesquisas no setor público. No caso específico de instituições públicas, onde há uma constante alternância nos altos cargos administrativos, a iniciativa de se definir e registrar as diferentes dimensões do desenho organizacional, de forma a evidenciar as interdependências e o equilíbrio dinâmico existente entre estas dimensões, resulta em um significativo benefício administrativo. 


\section{METODOLOGIA}

O ponto de partida para uma pesquisa é estabelecer sua estrutura e as questões que serão pesquisadas. Especialmente no caso de construção de teoria, é necessário ter uma visão geral dos fatores chave, construtos ou variáveis que se pretende estudar, e das relações presumidas entre eles. Miles e Huberman (1994) sugerem que se construa um mapa conceitual que explique o que será estudado. $A$ estrutura deste trabalho pode ser visualizada no mapa conceitual já apresentado na Figura 1.1.

O próximo passo é o estabelecimento de uma ou mais questões a serem pesquisadas, para conferir um foco definido à pesquisa e direcionar a coleta de dados. Neste trabalho, as questões a serem respondidas são: "Como deve ser o desenho organizacional adotado por uma empresa pública brasileira do setor de semicondutores?" e "Como interagem as diversas dimensões do desenho organizacional de uma empresa pública brasileira do setor de semicondutores entre si e com o ambiente?".

Para responder a estas questões, será realizado um estudo de caso em uma empresa pública brasileira do setor de semicondutores. A empresa selecionada para este estudo de caso consiste em um empreendimento único no Brasil. A abordagem utilizada será qualitativa. Os instrumentos de pesquisa serão os seguintes:

- Observação - realizada ao longo do desenvolvimento do caso;

- Análise documental - realizada a partir da coleta de arquivos e registros gerados durante o caso;

- Entrevistas - com funcionários da instituição estudada.

O estudo de caso é um dos métodos de pesquisa mais utilizados na engenharia de produção, particularmente no desenvolvimento de novas teorias. Pode ser definido como a "história de um fenômeno passado ou presente, extraída a partir de múltiplas fontes de evidências" (VOSS; TSIKRIKTSIS e FROHLICH, 2002). Entre as vantagens do estudo de caso, pode-se citar a possibilidade de estudar o fenômeno em seu cenário natural e gerar teoria relevante e significativa por meio da 
observação da realidade. Além disso, o estudo de caso permite responder a questões com uma compreensão relativamente ampla da natureza e da complexidade do fenômeno. O estudo de caso pode ser utilizado para diferentes tipos de propósitos de pesquisa, como exploração, construção de teoria, teste de teoria ou extensão e refinamento de teoria.

O método de pesquisa selecionado - Estudo de Caso Único - pode ser justificado com base em cinco fundamentos lógicos, apresentados por Yin (2010): (1) caso decisivo, (2) caso raro ou extremo, (3) caso representativo ou típico, (4) caso revelador e (5) caso longitudinal. O estudo de caso do presente trabalho pode ser definido como um caso raro, uma vez que a empresa é a única empresa pública de semicondutores no Brasil, o que justifica sua escolha como objeto de estudo. Eisenhardt (1989) argumenta que, quando o objetivo do estudo do caso é a construção ou extensão da teoria, faz sentido escolher casos específicos, em que o assunto a ser estudado é facilmente observável.

Miguel et al (2010) propõe que a condução de um estudo de caso siga as seguintes etapas:

- Definir uma estrutura conceitual-teórica - inclui as atividades de mapear a literatura, delinear as proposições e delimitar as fronteiras e o grau de evolução do estudo de caso;

- Planejar o caso - inclui as atividades de selecionar a unidade de análise e os contatos, escolher os meios para coleta e análise dos dados e definir os meios de controle da pesquisa;

- Conduzir teste piloto - inclui testar os procedimentos de aplicação. Verificar a qualidade dos dados e fazer os ajustes necessários;

- Coletar os dados - inclui contatar os casos, registrar os dados e limitar os efeitos do pesquisador;

- Analisar os dados - inclui produzir a narrativa, reduzir os dados, construir o painel de dados e identificar causalidades;

- Gerar relatório - inclui desenhar as implicações teóricas e prover uma estrutura para replicação da pesquisa. 
Ao se realizar um estudo de caso, deve-se ter especial atenção com a confiabilidade e a validade durante a coleta e análise dos dados. Segundo Yin (2010), a validade e a confiabilidade apresentam as seguintes dimensões:

- Validade de construtos - é a extensão do estabelecimento de medidas operacionais corretas para os conceitos que serão estudados;

- Validade interna - é a extensão do estabelecimento de relações de causa e efeito;

- Validade externa - verifica se os achados de um estudo se aplicam a casos similares;

- Repetitividade - mede em que extensão um estudo pode ser reaplicado, com os mesmos resultados.

Com base no estudo de caso, pretende-se analisar o desenho organizacional, considerando todas as suas dimensões - estratégia, pessoas, sistemas de recompensa, processos e estrutura organizacional -, além das interações entre as dimensões e entre estas e o ambiente de atuação, considerando a realidade de empresa pública da organização em estudo. O estudo de caso é adequado para se alcançar este objetivo, uma vez que ele gera conhecimento específico, criado no próprio contexto que se deseja estudar. Pretende-se trazer contribuição tanto para a prática, uma vez que os resultados obtidos na análise poderão ser utilizados pela própria organização em estudo ou por organizações similares, como para a teoria, já que são mais escassos os trabalhos sobre desenho organizacional para organizações públicas brasileiras. 


\section{ESTUDO DE CASO}

A organização onde foi conduzido o estudo de caso do presente trabalho é uma empresa pública brasileira (Organização $A$ ) do setor de semicondutores, criada em 2008 pelo governo federal, sob a forma de sociedade por ações de capital fechado, vinculada ao Ministério da Ciência, Tecnologia e Inovação. O investimento feito na Organização A objetivou o desenvolvimento da indústria eletrônica brasileira, através da implantação de uma base sólida no setor de semicondutores. Em países desenvolvidos, cerca de $12 \%$ do PIB é gerado pela indústria eletrônica. No Brasil, a participação deste segmento é de menos de $2 \%$ do PIB (CTI, 2010), fato que incentivou o investimento na criação da Organização $A$.

Conforme o decreto de criação, a Organização A tem por função social o desenvolvimento de soluções científicas e tecnológicas que contribuam para o progresso e o bem-estar da sociedade brasileira. Sua finalidade consiste em explorar diretamente a atividade econômica no âmbito das tecnologias de semicondutores, microeletrônica e áreas correlatas. Segundo sua lei de criação, compete à Organização $A$ realizar as seguintes atividades:

- Produção e comercialização de dispositivos semicondutores e sistemas de circuitos integrados, além de outros produtos de microeletrônica, para atender demandas específicas do mercado nacional e internacional;

- Comercialização e concessão de licenças ou de direitos de uso, de marcas e patentes de bens ou de produtos resultados de seus trabalhos, além de transferência de tecnologias adquiridas ou desenvolvidas na Organização A;

- Prestação de serviços de consultoria e assistência técnica especializada no âmbito de sua atuação, bem como de serviços especializados de manutenção, testes de conformidade, medição, calibração, certificação de produtos, normalização, aferição de ensaios e testes de padrões, aplicáveis a instrumentos, equipamentos e produtos;

- Elaboração de testes de lotes de circuitos integrados prototipados pela Organização A com a análise de sua viabilidade técnica, econômica e financeira;

- Atração de investimentos de interesse estratégico em sua área de atuação. 
A atividade descrita neste último item deixa claro que o governo brasileiro teve a intenção, inclusive, de fomentar o desenvolvimento de um arranjo produtivo regional (APR) para o setor de microeletrônica. Outro objetivo do governo brasileiro estava relacionado ao desenvolvimento de competências específicas para o setor, conforme pode ser observado nas atividades descritas a seguir, que também constam na lei de criação da Organização A:

- Formação de recursos humanos, capacitação e intercâmbio de técnicos e pesquisadores por meio de cursos, em articulação com instituições de ensino superior, centros de pesquisa e desenvolvimento, demais órgãos da administração pública direta e indireta e entidades empresariais;

- Disponibilização de infra-estrutura para permitir o domínio dos processos de pesquisa, desenvolvimento, projeto, prototipagem e testes em microeletrônica por pesquisadores, instituições de ensino superior, centros de pesquisa e desenvolvimento, demais órgãos da administração pública direta e indireta e entidades empresariais, bem como para desenvolver produtos em microeletrônica;

- Criação e consolidação de ambiente propício ao desenvolvimento científico e tecnológico integrado, articulando sua atuação em âmbito nacional e internacional;

- Promoção e suporte de empreendimentos inovadores, tanto na área de hardware como de software, com observância de padrões de formação e de competitividade compatíveis com o mercado internacional;

- Possibilitar o acesso a informações, a criação de parcerias, a redes de aperfeiçoamento tecnológico, de comercialização e de serviços;

- Elaboração de estudos e realização de pesquisas, desenvolvimento de tecnologias alternativas, produção e divulgação de conhecimentos técnicos e científicos para a promoção do desenvolvimento econômico e social, bem como experimentação de novos modelos produtivos; e

- Realização de pesquisa tecnológica e de inovação, isoladamente ou em conjunto com instituições de ensino superior, centros de pesquisa e desenvolvimento, demais órgãos da administração pública direta e indireta e entidades empresariais. 
A criação da Organização A foi resultado, portanto, da decisão política do Estado Brasileiro em participar, de modo ativo e direto, do desenvolvimento de pesquisa, indústria e comércio no setor de alta tecnologia, com a implantação da primeira indústria de semicondutores na América Latina. Diante desta missão estabelecida pela lei de sua criação, a Organização A enfrentava, no momento da presente pesquisa, o desafio de estabelecer-se no mercado como empresa produtiva e autossuficiente. No início de 2009 , foi nomeado o primeiro presidente da Organização A, sendo inaugurado seu centro de Design e tendo início a instalação da fábrica. Na época, foi contratado, para fins da implantação da Organização, pessoal técnico e administrativo por tempo determinado, uma vez que a contratação de pessoal efetivo só poderia ser realizada por meio de concurso público, difícil de ser realizado naquele momento. Em meados de 2010, após um período conturbado de troca da presidência, o novo presidente, com o objetivo de reacender na empresa os sensos de urgência e de missão necessários para o sucesso de uma empreitada desse nível de complexidade e ineditismo no país, reorganizou o setor administrativo e tomou algumas ações. Entre as ações tomadas, podem ser citadas a finalização das instalações da fábrica, para permitir a conexão de todas as ferramentas de fabricação, além da assinatura de contrato de operação e manutenção da infraestrutura da fábrica. Ambas as ações foram executadas até o início de 2011. $\mathrm{Na}$ época da presente pesquisa, a Organização A estava realizando o processo de aceitação da fábrica (certificação), requisito indispensável para iniciar suas operações. Para tanto, a empresa contratou consultoria técnica especializada no exterior, responsável pelas inspeções, verificações e testes necessários para garantir que a fábrica se encontrasse em perfeitas condições para operação. $\mathrm{Na}$ época, a Organização A apresentava uma unidade sede no Estado do Rio Grande do Sul, mas poderia estabelecer novos escritórios, tanto no Brasil como no exterior.

Outra ação tomada pelo novo presidente consistia no projeto da própria empresa, visando capacitá-la a operar de forma ágil e dinâmica no mercado de microeletrônica, um dos mercados industriais mais agressivos da economia moderna, sendo necessário, simultaneamente, respeitar as restrições de uma empresa financiada pelo Estado. Neste contexto, com o apoio da presidência e da 
diretoria da Organização A, foi desenvolvido o presente estudo de caso, acompanhando o projeto de reestruturação da empresa.

A Figura 4.1 apresenta uma linha do tempo com os principais acontecimentos ocorridos na Organização A:

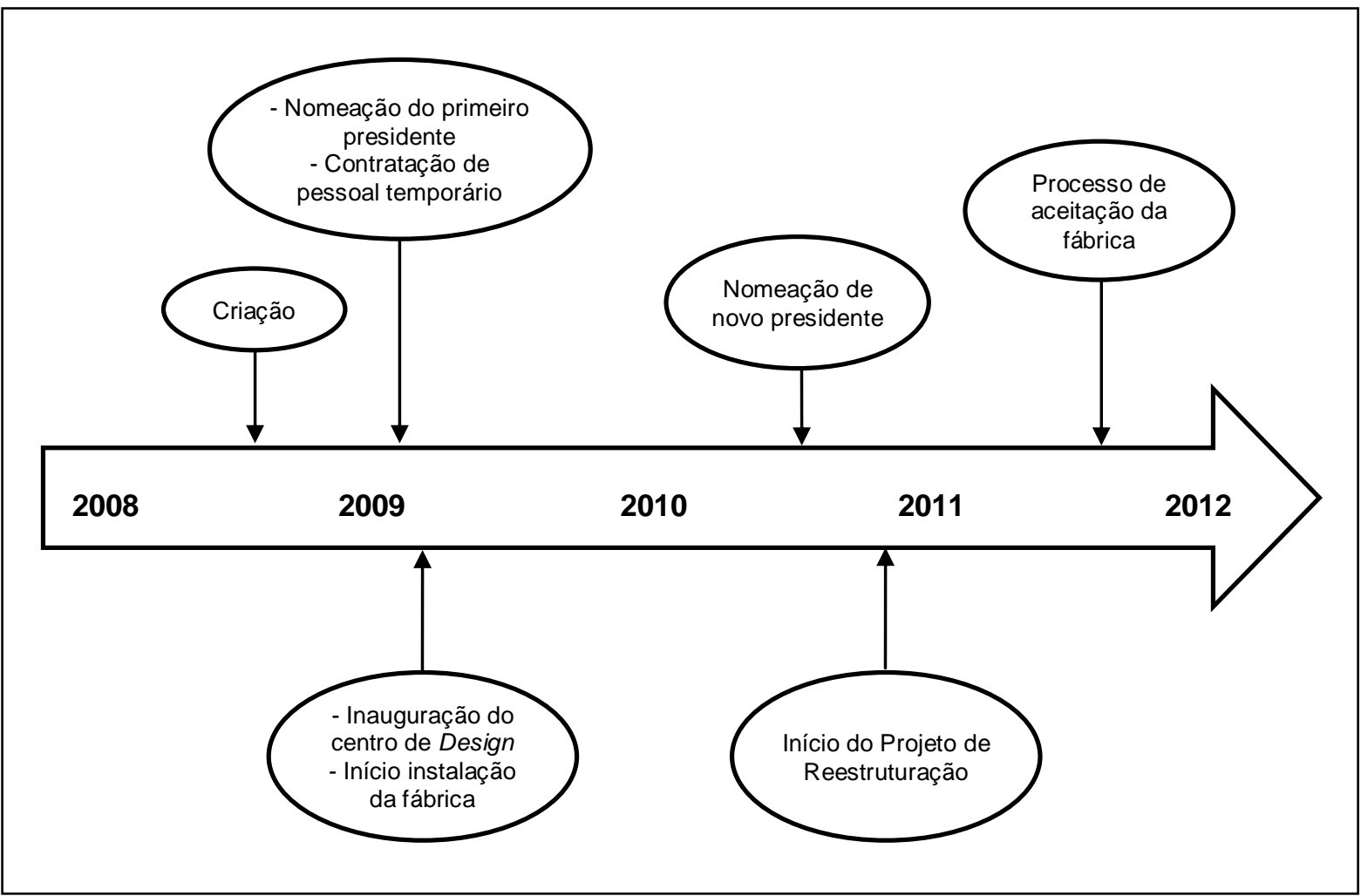

Figura 4.1 - Linha do Tempo da Organização A (elaborada pela autora)

O projeto de reestruturação organizacional foi conduzido em quatro frentes de trabalho:

1. Jurídico-legal - esta frente de trabalho buscou levantar aspectos do ambiente jurídico-legal que impactam nas operações da Organização A;

2. Estratégia - teve a finalidade de apoiar a direção da Organização A na definição do planejamento estratégico, estabelecimento de objetivos estratégicos e metas;

3. Pessoas e Sistemas de Recompensa - esta frente teve o objetivo de definir o modelo de gestão de pessoas e o plano de cargos e salários;

4. Processos e Estrutura Organizacional - visou levantar os macroprocessos, processos e subprocessos, tanto processos-fim como administrativos e de 
decisão, que devem ser executados pela Organização $A$, assim como definir a estrutura organizacional (organograma) mais apropriada para a operacionalização destes processos.

Durante o projeto de reestruturação da empresa, foram efetuadas reuniões, entrevistas e visitas técnicas à Organização $A$, visando compreender a realidade operacional e de gestão da empresa. Em um primeiro momento, foram identificadas e coletadas informações gerais sobre a empresa, além de serem levantadas as expectativas vivenciadas pelos grupos e áreas.

Com o objetivo de compreender o ambiente legal em que a Organização A deveria atuar, foi realizado um amplo levantamento da legislação aplicável à empresa, de forma a apoiar e direcionar as decisões referentes ao seu desenho organizacional em suas várias dimensões. Foram levantados os seguintes tipos de instrumentos regulatórios:

- Regramentos Internos;

- Legislação aplicável ao Setor de Semicondutores;

- Legislação sobre Compras e Licitações;

- Legislação aplicável à Gestão da Empresa Pública;

- Legislação Tributária Pertinente.

Nesse contexto de produção de inovação em ambiente competitivo nacional e internacional, para cumprir sua missão institucional, a Organização A tinha a necessidade de definir sua estratégia de atuação e de delinear seu planejamento estratégico, de forma a propiciar um direcionamento adequado à gestão de seus negócios e à construção de seu desenho organizacional.

\subsection{Ambiente da Organização}

O ambiente de atuação da Organização A, o setor de semicondutores, possui uma dinâmica de inovação bastante acelerada, marcada por elevadas taxas de inovação tecnológica, tanto no desenho dos produtos, como também em seus 
processos. O ambiente do setor de semicondutores também se caracteriza pela densidade e complexidade de suas tecnologias e pelo caráter intensivo em capital e em atividades de pesquisa e desenvolvimento (P\&D). Estas características geram elevados investimentos e riscos para os fabricantes desse segmento (CARVALHO, 2006).

Embora existam fortes aspectos motivadores para se desenvolver a indústria de semicondutores no Brasil, o setor ainda permanece restrito a um pequeno grupo de empresas. Entre os aspectos motivadores para o desenvolvimento deste setor, podem ser citados:

- Trata-se de um mercado global que em 2010 movimentou cerca de US\$295 bilhões (KPMG, 2011);

- Representa um dos principais setores responsáveis pelo comportamento dinâmico da indústria eletrônica contemporânea;

- A participação do Brasil nessa indústria ainda é bastante restrita;

- O segmento de eletroeletrônicos nacional está em fase de expansão, sendo que em 2011 houve um aumento de 14\% no faturamento das empresas eletroeletrônicas do Brasil, elevando-o para um patamar de $R$ \$140,5 bilhões no ano (ABINEE, 2012);

- O mercado brasileiro é abastecido principalmente por fornecedores externos, tanto em semicondutores, como em placas montadas e produto final, gerando um déficit significativo em sua balança comercial. De acordo com dados da ABINEE (Associação Brasileira da Indústria Elétrica e Eletrônica), o setor eletroeletrônico fechou sua balança comercial em 2011 com um déficit de mais de US\$ 32 bilhões, o que significa crescimento de $18 \%$ em relação ao ano anterior. Esse déficit é resultado das importações que atingiram US\$ 40 bilhões e das exportações que não chegaram aos US\$ 8 bilhões (ABINEE, 2011).

Diante desses fatos, existem várias discussões e estudos sobre formas de aumentar as atividades desse setor no país, além do debate recente sobre a necessidade da instalação de uma planta produtiva (foundry) realizado pelo governo. Neste contexto, foi criada a Organização $A$, que dentre os vários objetivos já 
mencionados anteriormente, pretende produzir semicondutores para uso em nichos específicos e fabricar chips baseados em projetos desenvolvidos no país. O foco em nichos de mercado específicos, inicialmente baseado em produtos de tecnologia já conhecida, constitui uma estratégia de entrada da Organização A em um setor caracterizado pelo alto dinamismo e inovação. A empresa, no entanto, deve permanecer em constante monitoramento de seu ambiente, uma vez que o governo brasileiro tem adotado incentivos a novos entrantes no mercado nacional, visando estimular o desenvolvimento e a instalação de novas empresas do setor.

Outro aspecto do ambiente da Organização A que impacta significativamente em suas atividades consiste no fato desta ser uma empresa pública, sendo necessário, portanto, cumprir uma série de procedimentos administrativos previstos na legislação. Como exemplo, podem-se citar os procedimentos de compras de bens e serviços, que devem seguir a Lei 8.666 de 21/06/93. Como grande parte dos fornecedores da Organização A são externos, a necessidade de cumprimento de procedimentos burocráticos para obtenção de matérias primas acaba amarrando suas atividades produtivas, fato que, em um ambiente rápido e dinâmico, como é o caso do setor de semicondutores, é extremamente desvantajoso para a empresa.

\subsection{Dimensão Estratégia}

Segundo o modelo proposto por Galbraith (2009), a Estratégia é a primeira dimensão que deve ser definida por uma organização. A Estratégia, que pode ser definida como a fórmula para alcançar o sucesso de uma organização, dá a direção da empresa, especificando as metas e os objetivos a serem atingidos, assim como os valores e a missão a serem perseguidos pela organização.

Os trabalhos executados pela frente estratégica foram desenvolvidos conforme a metodologia do Balanced Scorecard (BSC), descrito anteriormente, e envolveram as seguintes etapas: 
- Revisão da Estratégia;

- Construção do Mapa Estratégico;

- Definição de Indicadores de Desempenho Estratégicos;

- Definição e Gerenciamento de Metas Estratégicas;

- Definição de Projetos Estratégicos;

- Análise Periódica da Estratégia.

As atividades realizadas em cada etapa serão descritas de forma resumida a seguir.

\section{Revisão da Estratégia}

Durante a primeira etapa dos trabalhos, executada por cerca de dois meses, foi realizada a coleta de diferentes percepções da alta liderança e dos principais stakeholders a respeito do futuro da Organização A. Nesta etapa, foram realizadas 15 entrevistas com diferentes stakeholders, tanto da alta direção da empresa, como de representantes de empresas clientes e do governo local. As entrevistas seguiram um roteiro previamente elaborado. As questões foram formuladas visando a construção do mapa estratégico, além de provocar uma reflexão sobre a estratégia da organização, sua missão, visão e principais resultados esperados. Além disso, foi realizado workshop de capacitação em Gestão Estratégica com a alta administração, visando formar multiplicadores e garantir a continuidade dos trabalhos.

A seguir, foram formuladas e validadas, em conjunto com a alta administração, a missão e a visão de futuro da Organização A. Com o objetivo de uniformizar o conhecimento e a compreensão de todos, foi apresentado o conceito de missão, definida como "a declaração do propósito dominante de uma organização". Para facilitar o entendimento, foram apresentados alguns exemplos de missão de outras organizações públicas brasileiras. Da mesma forma, foi discutido o conceito de visão de futuro, que "indica uma realidade futura possível descrita de forma simples, objetiva, partilhada por todos os dirigentes e colaboradores da organização", sendo apresentados alguns exemplos de empresas públicas 
brasileiras. A missão e a visão da Organização $A$, formuladas e validadas durante o workshop, foram as seguintes:

Missão: "Desenvolver soluções inovadoras em Microeletrônica, com alto padrão de qualidade e sustentabilidade financeira, atendendo às necessidades estratégicas do Brasil e do mercado, contribuindo para o desenvolvimento nacional".

Visão: "Ser empresa nacional líder da cadeia produtiva do setor e referência na geração de soluções inovadoras em Microeletrônica em economias emergentes, contribuindo para o desenvolvimento social, tecnológico e econômico do País".

\section{Construção do Mapa Estratégico}

A seguir, foi construído o mapa estratégico da Organização $A$, segundo o modelo do BSC. O mapa estratégico do BSC descreve a estratégia da empresa através de objetivos relacionados entre si e distribuídos em quatro dimensões financeira, cliente, processos internos e aprendizado e conhecimento (KAPLAN e NORTON, 2004). Desta maneira, o mapa evidencia quais os desafios a serem superados para concretizar a missão e a visão de futuro da organização. O mapa estratégico da Organização A foi construído com base nas informações levantadas nas entrevistas, no Estatuto e no Regimento da organização, no relatório de Gestão, em reportagens de jornais e em reuniões e conversas informais. O mapa estratégico obtido, validado em workshop com os gestores da Organização $A$, englobava ao todo 17 objetivos estratégicos, divididos nas perspectivas "Sociedade", "Financeira", "Mercado", "Processos Internos" e "Pessoas e Gestão e Informação":

- Impulsionar o desenvolvimento da cadeia produtiva de microeletrônica no país;

- Buscar competitividade nos custos;

- Buscar a autossustentabilidade financeira;

- Ampliar e diversificar receitas; 
- Posicionar-se como projetista e fabricante de chips para fornecedoras de programas governamentais;

- Conquistar mercado de circuitos integrados específicos;

- Dominar os processos de fabricação;

- Desenvolver e consolidar processos de acordo com padrões internacionais de qualidade e de segurança do trabalho;

- Desenvolver soluções com foco em RFID (radio-frequency identification) e wireless;

- Desenvolver relacionamento com o mercado;

- Incentivar empresas brasileiras a serem usuárias de microeletrônica;

- Buscar excelência no planejamento da operação com processos de gestão;

- Articular ações políticas junto ao Legislativo e ao Executivo;

- Desenvolver parcerias com as partes interessadas;

- Atrair, desenvolver e reter pessoas;

- Promover cultura e ambiente de trabalho favorável ao alto desempenho e resultados;

- Aplicar tecnologias de gestão.

\section{Definição de Indicadores de Desempenho Estratégicos}

Uma vez construído e validado o mapa estratégico, passou-se para a próxima etapa dos trabalhos, a definição de indicadores estratégicos. Os indicadores estratégicos foram definidos com base nos objetivos estratégicos descritos no mapa. Para cada objetivo foi criado um conjunto de indicadores. Inicialmente, foram validados, em conjunto com os gestores da Organização A, os seguintes itens referentes a cada indicador a ser criado:

- Informações gerais sobre o indicador;

- Parâmetros do indicador;

- Apuração e análise dos dados;

- Metas;

- Plano de Desenvolvimento do Indicador. 
A seguir, foi levantado, em conjunto com os gestores da Organização A, um conjunto de indicadores específicos para cada objetivo do mapa estratégico, gerando-se uma lista de 41 sugestões de indicadores. Visando selecionar os indicadores mais viáveis para medição, cada sugestão de indicador foi avaliada com relação à facilidade de quantificação, acessibilidade e facilidade de entendimento, utilizando notas de 1 a 5 (5 = melhor; 1 = pior). Como resultado da avaliação, 33 indicadores foram selecionados para detalhamento junto aos gestores da Organização A. Para o detalhamento de cada indicador, foi utilizada uma "Ficha do Indicador", constando os seguintes itens principais:

- Informações gerais do indicador - nome do indicador de desempenho, descrição do indicador, objetivo estratégico a que se relaciona, perspectiva (do mapa estratégico), responsável pelo indicador;

- Parâmetros do indicador - fórmula, unidade de medida, razão de medição;

- Informações para apuração e análise dos dados - periodicidade de medição, fonte de dados, responsável pela medição, critérios de análise, responsável pela análise;

- Metas - desempenho esperado no curto prazo, desempenho esperado no longo prazo, gráficos com o histórico de medições;

- Melhorias para o Indicador - plano de ação, responsável pelo plano de ação e observações.

\section{Definição e Gerenciamento de Metas Estratégicas}

A definição de metas para os indicadores estratégicos pelos gestores da Organização A ocorreu simultaneamente com a definição dos indicadores, sendo que o detalhamento das metas foi executado com o apoio da mesma "Ficha do Indicador". Para o gerenciamento das metas, foi elaborada uma planilha com um modelo integrado de metas, apresentando a interação entre as metas estabelecidas para os próximos 5 anos (metas plurianuais) e os objetivos estratégicos. A planilha foi construída utilizando a mesma distribuição espacial do mapa estratégico, de forma a facilitar a visualização das interações entre metas, objetivos e perspectivas. 


\section{Definição de Projetos Estratégicos}

$\mathrm{Na}$ etapa seguinte, foram identificados os projetos estratégicos existentes na Organização, ou que deveriam ser criados, de forma a impactar no mapa estratégico e possibilitar à organização atingir suas metas estratégicas. Neste ponto, vale a pena retomar a definição de projeto: Um projeto consiste em um empreendimento (iniciativa) único, com início e fim bem definidos, para alcançar um determinado objetivo para um cliente ou solicitante (GIDO e CLEMENTS, 2007). Um projeto se diferencia de um processo por ter um prazo definido para atingir seu objetivo, enquanto um processo consiste em uma sequência de atividades que uma empresa executa continuamente, para produzir bens e/ou serviços. No caso dos projetos estratégicos, o objetivo a ser alcançado é o próprio objetivo estratégico descrito no mapa, sendo que o cliente do projeto é a alta diretoria, ou a própria organização.

Foram identificados, pelos gestores da Organização A, 21 projetos estratégicos, distribuídos em cinco temas: Operação da Fábrica, Tecnologia, Soluções e Design, Institucionalização e Parcerias e Pessoas. Cada projeto estratégico foi detalhado, conforme um "Termo de Abertura de Projeto", constando os seguintes itens principais:

- Dados gerais - nome do projeto, gestor, patrocinador, data de início, data de término, investimento, descrição do projeto, impacto nos objetivos estratégicos e justificativa;

- Objetivo e escopo - objetivo do projeto, escopo e produtos e/ou serviços resultantes;

- Principais atividades e cronograma;

- Riscos e possíveis impactos;

- Observações gerais.

Após o detalhamento dos vários projetos estratégicos, cada projeto foi avaliado em termos de seu impacto em cada um dos objetivos do mapa estratégico. Esta atividade foi executada pelos gestores da Organização A, obtendo-se como 
resultado uma Matriz de Avaliação dos Projetos Estratégicos. Os projetos também foram avaliados segundo os critérios prazo de execução e volume de investimento necessário.

\section{Análise Periódica da Estratégia}

A última etapa dos trabalhos de definição e implementação da estratégia consistiu no próprio processo de Análise da Estratégia da Organização A, que deveria ser executado de forma periódica, visando avaliar regularmente o desempenho da organização no sentido de alcançar as metas estratégicas propostas, reavaliar o ambiente de mercado e as capacidades internas e revisar o planejamento estratégico existente. A sequência de atividades do processo foi construída e apresentada à alta administração em forma de tabela, constando um detalhamento das atividades a serem executadas, e em forma de fluxograma. $\mathrm{Na}$ tabela, é apresentado um detalhamento das atividades de coletar e monitorar, analisar, gerar alternativas de solução, preparar a decisão, decidir e comunicar. Para apoiar a execução do processo de Análise da Estratégia, foram elaborados modelos de formulários para análise do contexto externo, acompanhamento das ações anteriores, análise geral da estratégia e de cada objetivo estratégico específico, além de modelos de pauta e atas.

\subsection{Dimensão Pessoas}

A segunda dimensão do desenho organizacional que deve ser definida por uma organização é a dimensão Pessoas. Nesta dimensão, podem ser analisadas variáveis como competências essenciais para o negócio, habilidades necessárias, estilo de liderança, treinamento e desenvolvimento, transferência e seleção de pessoal, clima organizacional, entre outras.

A Organização A, criada em 2008, passava na época do presente estudo por um momento bastante delicado em relação à gestão de pessoas. Conforme sua lei de criação, a contratação de pessoal da Organização A deve seguir o regime jurídico 
da Consolidação das Leis do Trabalho - CLT, e deve ser realizada por meio de concurso público de provas ou de provas e títulos. Para fins da implantação da organização, entretanto, foi permitido à Organização $A$ a contratação temporária de pessoal técnico e administrativo por tempo determinado. Além disso, a Organização A também tem autorização para estabelecer convênios de cooperação técnica com órgãos e entidades da administração pública, objetivando permitir a utilização, por prazo determinado, de servidores de outros órgãos e entidades para viabilizar as atividades técnicas e administrativas indispensáveis ao seu funcionamento inicial. Esta contratação temporária, considerada de excepcional interesse público, no entanto, não poderia exceder o prazo de 24 meses, a contar da data da instalação da Organização A, prorrogável por no máximo mais 12 meses. Este prazo, que se esgotava na época do presente estudo, somado ao aquecimento do mercado de trabalho no Brasil, gerava significativa instabilidade no quadro de colaboradores da empresa.

A Gestão de Pessoas da Organização A demandava, portanto, três ações urgentes:

- Definição de um Plano de Cargos, Carreiras e Remuneração (PCCR);

- Realização de Concurso Público para efetivação de pessoal, com base no plano de cargos e salários definido na primeira ação;

- Elaboração do Regulamento de Pessoal.

\section{Definição de Plano de Cargos, Carreiras e Remuneração (PCCR)}

Para dar início aos trabalhos, foi realizado um workshop, com a presença de todos os colaboradores da Organização A, com o objetivo de explanar os conceitos envolvidos na gestão de pessoas, bem como os conceitos recomendados pelo DEST (Departamento de Coordenação e Governança das Empresas Estatais) para o desenvolvimento de planos de cargos para órgãos públicos federais: cargos generalistas, nível de complexidade, avaliação da competência, salários compatíveis com o mercado, plano de função separado do plano de cargos, etc. 
A seguir, foi realizado um levantamento de informações gerais sobre a gestão de pessoas na Organização A, o que permitiu elaborar um estudo inicial do plano de cargos, com uma definição preliminar de cargos e funções comissionadas. Foram entrevistados técnicos e gestores da organização para levantamento de opinião sobre atribuições dos cargos, níveis de complexidade das atribuições e responsabilidades, nomenclatura dos cargos e aglutinação dos atuais cargos (na época do estudo) em cargos generalistas. Para a definição de cargos, foram realizadas, também, pesquisas de benchmarking com outras empresas dos setores de semicondutores e de microeletrônica. Com base neste levantamento inicial, foi elaborada a seguinte proposta de aglutinação dos atuais cargos da Organização A em cargos generalistas:

\section{Nível Superior:}

\section{- Especialista em Projetos de Circuitos Integrados}

Englobaria as atribuições dos atuais:

- Projetista Analógico;

- Projetista de Rádio-frequência;

- Projetista Digital.

\section{- Especialista em Desenvolvimento de Softwares}

Englobaria as atribuições dos atuais:

- Analista de Sistema Informatizado Integrado;

- Analista de Sistema Informatizado Integrado de Manufatura de Semicondutores;

- Projetista de Software Embarcado;

- Analista de Suporte Técnico de Informática.

\section{- Especialista em Manutenção e Processos de Fabricação de Circuitos} Integrados

Englobaria as atribuições dos atuais:

- Analista de Manutenção de Equipamentos de Semicondutores;

- Analista de Processo de Fabricação;

- Engenheiro de Segurança. 
- Especialista em Desenvolvimento de Produtos e Negócios

- Engenheiro de Aplicação de Microeletrônica;

- Engenheiro de Produtos de Microeletrônica;

- Engenheiro de Testes de Produtos de Microeletrônica I.

\section{- Analista Administrativo e Operacional}

Englobaria as atribuições dos atuais:

- Analista Administrativo Financeiro;

- Analista Comercial;

- Analista Contábil;

- Analista de Arquivo;

- Analista de Compras;

- Analista de Logística;

- Analista de Marketing;

- Analista de Qualidade;

- Analista de Recursos Humanos;

- Analista de Sistemas;

- Analista Jurídico.

\section{Nível Médio Profissionalizante:}

- Técnico em Desenvolvimento e Fabricação de Circuitos Integrados

Englobaria as atribuições dos atuais:

- Técnico de Laboratório Eletrônico;

- Técnico de Processo de Fabricação de Semicondutores (Químico, Elétrico, Mecânico, Instrumentação e Automação, Equipamentos);

- Técnico em Automação de Projetos em Microeletrônica. 


\section{Nível Médio:}

\section{- Técnico de Suporte Administrativo e Operacional}

Englobaria as atribuições dos atuais:

- Técnico de Enfermagem do Trabalho;

- Técnico de Segurança do Trabalho;

- Operadores de Máquina de Produção I;

- Operadores de Máquina de Produção II.

Somando-se a este levantamento interno, foi realizada pesquisa na internet sobre ofertas de emprego para os cargos que são demandados pela Organização A, tanto dos requisitos exigidos como das atribuições e responsabilidades que os candidatos deveriam exercer. Além disso, foram pesquisados os valores dos salários ofertados a profissionais ocupando cargos iguais aos demandados pela Organização A, bem como foi levantada a situação dos cargos e salários em três empresas federais com alguma similaridade com a organização em estudo. Com base nestas informações iniciais levantadas, foram elaboradas propostas iniciais do Plano de Cargos, Carreiras e Remuneração, do Plano de Funções em Comissão, do Regulamento de Progressão e Promoção e do Regulamento de Gratificação de Desempenho. A seguir, estas propostas iniciais foram apresentadas aos gestores (presidente e diretoria) da Organização A para validação, assim como os resultados da pesquisa sobre remuneração. Por iniciativa do próprio presidente, os documentos apresentados para validação foram encaminhados a todos os colaboradores da Organização A, para análise crítica e encaminhamento de sugestões. Após o recebimento destas, foram elaboradas versões refinadas, que serão apresentadas em maior detalhe na dimensão Sistemas de Recompensa desta pesquisa.

\section{Realização de Concurso Público}

Para dar início aos trabalhos de realização do Concurso Público, foram realizadas entrevistas com o diretor administrativo e financeiro e com o responsável pelo setor de Recursos Humanos da Organização A, com o propósito de apreender as necessidades e perspectivas da empresa para o concurso público a ser realizado, 
além de levantar a situação jurídica dos colaboradores que já atuavam na empresa, em regime de contratação temporária. Um primeiro ponto a ser levantado consistiu no acordo que a Organização A firmou com o DEST (Departamento de Coordenação e Governança das Empresas Estatais) a respeito do aproveitamento e melhoria da situação de tais colaboradores (cerca de 110 funcionários). Segundo os gestores da empresa, seriam criadas, em um primeiro momento, funções técnicas de livre provimento e exoneração, mas sujeitas às regras da CLT, que seriam ocupadas pelos contratados temporários que fossem aprovados em avaliação de desempenho. Estas funções técnicas deveriam ser transformadas, gradativamente, em empregos da estrutura de quadros de pessoal, por meio da realização de concursos públicos.

Segundo os gestores da empresa, o concurso deveria ser realizado de forma terceirizada, por instituição especializada. Seria necessário naquele momento, portanto, elaborar o Termo de Referência do concurso, bem como o respectivo Edital para a contratação da empresa especializada que seria a responsável pela realização do concurso. Foram levantadas, então, informações a respeito das características do concurso quanto ao tipo de prova, conteúdo, exigência de títulos e experiência profissional dos candidatos. A necessidade de ser aplicada prova de língua estrangeira, no caso inglês, foi destacada pelos gestores, inclusive aos candidatos às áreas administrativas. No caso das vagas para as áreas de Design e Fábrica, seria necessária, também, a aplicação de prova oral, no formato de defesa de memorial. Os membros da banca examinadora poderiam ser escolhidos pela empresa contratada para realizar o concurso, desde que o perfil de cada membro da banca fosse indicado pela Organização A. Os gestores enfatizaram ainda o interesse da Organização A em contratar representantes comerciais. Para tanto, a empresa manteria uma diretoria comercial e de negócios, com poucos colaboradores, que seria auxiliada pelos representantes comerciais.

A seguir, foram levantadas informações para a fixação de diretrizes a serem seguidas na elaboração das minutas de editais para os concursos da Organização A. Foram realizadas entrevistas com instituições especializadas na realização de concursos públicos, sendo abordados os seguintes pontos: 
- Conhecimento das características dos contratos firmados para a execução de concursos públicos;

- Levantamento de diferentes propostas de concepção e desenvolvimento de concursos disponíveis no mercado;

- Identificação da metodologia adotada pelas instituições atuantes neste ramo para a customização do concurso às características da Organização $A$;

- Registro das formas de definição de preço adotadas pelas instituições pesquisadas.

Considerando as especificidades dos cargos a serem preenchidos e a perspectiva da Organização A quanto ao perfil de profissional que se desejava contratar, foram levantadas, para a elaboração do edital do concurso, as seguintes premissas:

- Análise da possibilidade e das eventuais vantagens obtidas com a realização de concursos distintos para: (a) projetistas e engenheiros com determinadas especializações e para (b) profissionais relacionados às atividades administrativas da empresa e operários;

- Para o provimento de empregos que demandassem qualificação diferenciada, de característica eminentemente técnica, deveria ser avaliada a possibilidade de realização de prova prática, defesa de memorial e/ou curso de formação;

- Deveria ser prevista a realização de prova de títulos no âmbito do concurso. Entretanto, além da pontuação para especialização, mestrado e doutorado, deveriam ser considerados outros cursos e treinamentos relacionados às áreas de conhecimento dos profissionais da Organização $A$, interessantes para a qualificação do quadro de funcionários da empresa, mas que poderiam não possuir o devido reconhecimento do MEC (Ministério da Educação). Assim, deveria ser avaliada a possibilidade de se atribuir ao setor de Recursos Humanos da Organização A a avaliação destes cursos, mediante emissão de parecer, como meio de fundamentar a concessão da pontuação ao candidato;

- Tendo em vista que se tratava do primeiro concurso da Organização A, seria interessante que o procedimento selecionasse profissionais com níveis de 
experiência diferenciados. Assim, deveria ser examinada a possibilidade de ingresso de profissionais em níveis intermediários das carreiras, e não apenas nos níveis iniciais;

- Em relação à seleção de profissionais para a Fábrica, a necessidade de avaliação do desempenho prático do candidato recomendava a realização de um curso de formação, como última etapa do concurso.

Com base nas entrevistas com instituições executoras de concursos, e ainda nas premissas levantadas, foram elaboradas as diretrizes para a realização do Concurso Público, que foram apresentadas para apreciação pelos gestores da Organização A, sendo validadas pelos mesmos. A seguir, foi elaborada uma versão preliminar do Termo de Referência e da Minuta do Edital de Concurso Público. O dimensionamento do quadro, necessário para a definição do número de vagas, tanto de Cargos como de Funções em Comissão, foi definido pela diretoria e submetido à aprovação do Conselho de Administração e dos órgãos de controle das empresas estatais. O suprimento das vagas seria feito por remanejamento interno ou por concurso público, conforme resultado da aplicação anual da sistemática de dimensionamento do quadro, regulamentada pela direção da Organização A.

\section{Elaboração do Regulamento de Pessoal}

Outra demanda da Organização A estava relacionada à elaboração do Regulamento de Pessoal, conduzida em paralelo e em consonância com o Plano de Cargos, Carreiras e Remuneração. Para o desenvolvimento do Regulamento de Pessoal, foram conduzidas reuniões com os gestores da Organização A, visando apreender as principais necessidades da empresa. As questões tratadas nas reuniões relacionaram-se aos objetivos e às necessidades da Organização A quanto ao regime jurídico de pessoal, tendo em vista suas finalidades institucionais. O Regulamento de Pessoal tem como função definir claramente as regras de relacionamento entre a empresa e o colaborador, para pleno atendimento das obrigações e direitos contraídos quando da contratação. Ao colaborador cumpre observar seus deveres e obrigações, enquanto ao empregador cabe oferecer 
condições de trabalho e desenvolvimento profissional. Desta forma, o Regulamento de Pessoal da Organização A deveria ser elaborado para disciplinar as relações da empresa com seus colaboradores, por meio da fixação de regras claras que davam segurança e garantiam um bom relacionamento entre as partes. No Regulamento de Pessoal deveriam constar os seguintes pontos:

- Regras para acesso aos colaboradores (provimento, recrutamento, seleção e admissão);

- Regras quanto aos direitos, deveres e responsabilidades dos colaboradores;

- Regras para instauração de sindicância e aplicação de penalidades;

- Disciplina da progressão e promoção dos colaboradores, inclusive por meio da indicação de índices de desempenho;

- Regras sobre remuneração dos colaboradores, incluindo gratificações por desempenho;

- Regras sobre fomento dos recursos humanos.

Com base nas reuniões com os gestores da Organização A, foi elaborada uma minuta de Regulamento de Pessoal, constando diretrizes e objetivos para nortear a política de recursos humanos. A minuta de Regulamento de Pessoal elaborada foi apresentada ao Conselho de Administração da Organização A para apreciação, sendo elaborada uma versão final com base nas discussões realizadas.

\subsection{Dimensão Sistemas de Recompensa}

A terceira dimensão do desenho organizacional que deve ser definida por uma organização é a dimensão Sistemas de Recompensa. Esta dimensão pode apresentar como variáveis a serem estudadas a motivação, o sistema de compensação, a base de promoção e planos de carreira, que apresentam significativo impacto na satisfação do pessoal.

O Sistema de Recompensa desenvolvido para a Organização A é composto pelos seguintes elementos: 
- Plano de Cargos, Carreiras e Remuneração (PCCR) - define os mecanismos de atração, desenvolvimento, valorização e retenção de profissionais para que a empresa cumpra a sua missão institucional e atenda às expectativas da sociedade e do mercado;

- Plano de Funções em Comissão (PFC) - complementa o PCCR, em apoio ao desenvolvimento e à valorização dos colaboradores, uma vez que define as regras para ocupação dos postos de direção e de assessoramento técnico-administrativo;

- Regulamento de Progressão e Promoção - define as condições, as regras e os procedimentos relativos aos processos de progressão e promoção para os colaboradores da Organização A, aplicando-se a todos os colaboradores da empresa;

- Regulamento de Remuneração Variável e Gratificação de Desempenho define as condições, as regras e os procedimentos relativos à Gratificação de Desempenho, uma quantia variável a ser paga ao colaborador, sem incorporação desta à sua remuneração, como recompensa pelo alcance das metas definidas pela Diretoria da empresa.

A seguir, cada um dos componentes do Sistema de Recompensa da Organização A será apresentado em detalhe.

\section{Plano de Cargos, Carreiras e Remuneração (PCCR)}

O Plano de Cargos, Carreiras e Remuneração (PCCR) da Organização A foi desenvolvido com o objetivo de definir os mecanismos de atração, desenvolvimento, valorização e retenção de profissionais para que a empresa cumprisse sua missão institucional $\mathrm{e}$ atendesse às expectativas da sociedade e do mercado. A área de Recursos Humanos passaria a ter um papel fundamental na gestão do PCCR, uma vez que se tornaria uma parceira estratégica das demais áreas da Organização $A$, pois seriam criados os mecanismos para dotar os quadros da empresa com pessoal qualificado, necessário ao atendimento de suas demandas atuais e futuras. A manutenção da qualidade profissional dos colaboradores estaria garantida pelas regras de desenvolvimento na carreira, baseadas exclusivamente no aumento do 
patrimônio de conhecimentos e de habilidades do colaborador e da sua capacidade em traduzir esse patrimônio em resultados efetivos para a Organização A. Pelas regras do PCCR, o colaborador precisaria desenvolver sua capacidade profissional, adquirindo condições para exercer atividades com níveis de complexidade cada vez maiores, para poder se habilitar à promoção no cargo. $O$ pressuposto seria que 0 desenvolvimento contínuo dos colaboradores conduziria ao desenvolvimento, também contínuo, da Organização A.

Para a elaboração do Plano, com base nas especificidades da Organização A e de seu ambiente de atuação, foram considerados os seguintes aspectos fundamentais:

- Necessidade de existir flexibilidade organizacional;

- Necessidade de aumento da capacidade de desenvolvimento e de inovação das pessoas;

- Necessidade de se criar instrumentos de gestão de pessoas que permitissem que a organização pudesse superar os desafios de seu planejamento estratégico.

Desta maneira, o Plano atenderia às reais necessidades da organização em constituir um quadro de pessoal profissional que atendesse às suas especificidades, além de estar compatível com as diretrizes e recomendações dos órgãos de controle das empresas estatais. O PCCR elaborado apresentou inicialmente uma definição dos conceitos básicos adotados, para uniformização do conhecimento de todos os envolvidos. Foram adotados os seguintes conceitos:

- Avaliação - consiste na verificação formal e sistemática dos resultados alcançados pelos colaboradores, comparados com os padrões de desempenho e de desenvolvimento estabelecidos;

- Captação de Pessoas - conjunto de procedimentos que visa atrair e selecionar candidatos potencialmente qualificados e capazes de ocupar cargos na empresa; 
- Cargo - conjunto de ações e tarefas quanto à natureza do trabalho, à complexidade e às competências exigidas para sua execução. Os cargos são de natureza permanente e acompanham a trajetória do profissional durante sua permanência na organização. Os cargos reúnem informações relacionadas à formação, experiência, conhecimento, situação funcional e processo seletivo requeridos;

- Carreira - conjunto de classes salariais hierarquizadas segundo seus níveis de complexidade. Indica a trajetória que o colaborador deverá percorrer ao longo de sua vida profissional na Organização A;

- Certificação da Proficiência do Colaborador - atestado de que o colaborador encontra-se apto a exercer com excelência as atribuições e responsabilidades exigidas para a Classe superior à ocupada e que, portanto, poderá ser promovido;

- Certificação Institucional - validação de conhecimentos obtidos pelo colaborador e necessários à sua evolução na carreira;

- Classe - consiste no escalonamento do nível de complexidade das atribuições e responsabilidades, expressas por padrões hierarquizados, dentro de um cargo;

- Competência - diz respeito a quanto valor o colaborador adiciona às atividades, produtos e resultados da empresa;

- Desenvolvimento de Carreira - corresponde ao processo de crescimento profissional do colaborador para assumir e executar atribuições de maior complexidade;

- Estrutura Salarial - conjunto de classes, níveis e padrões salariais inerentes aos cargos estabelecidos a partir do seu valor interno e de sua comparação com o mercado;

- Funções em Comissão - postos de trabalho definidos como cargos comissionados, funções de confiança e funções gratificadas, conforme Plano de Funções em Comissão;

- Gratificação pelo Desempenho - é a quantia variável a ser paga aos colaboradores, sem incorporação desta à remuneração, com a finalidade de recompensar a contribuição coletiva diferenciada para o alcance das metas definidas pela Diretoria da Organização A; 
- Nível de Complexidade - padrão de complexidade que está associado a uma determinada Classe do cargo;

- Padrão Salarial - diferentes valores de salários que compõem a tabela;

- Perfil do Cargo - descrição dos requisitos de escolaridade, experiência e competências necessárias ao desempenho de cada um dos cargos existentes na empresa;

- Progressão - movimentação de um padrão salarial para outro superior, dentro da mesma classe;

- Promoção - movimentação de uma classe para outra superior dentro do mesmo cargo;

- Remuneração - conjunto de valores representados pelo somatório do salário e parcelas adicionais de caráter permanente ou temporário;

- Requisitos de acesso - consistem no conjunto de requisitos exigidos e desejáveis para o preenchimento e exercício das atividades dos cargos em seus diferentes níveis de complexidade.

Os objetivos específicos do PCCR elaborado foram:

- Promover a integração das ações de gestão de pessoas e sua congruência com a missão, metas, planos e estratégias da Organização $A$;

- Orientar as atividades de captação de pessoas;

- Oferecer parâmetro para que os colaboradores possam se desenvolver e construir uma carreira de contínuo crescimento profissional e pessoal, agregando valor aos resultados da Organização A;

- Permitir aos colaboradores a visão de um horizonte profissional com critérios remuneratórios justos e equilibrados;

- Reconhecer as contribuições das pessoas e dos grupos para os resultados da empresa;

- Oferecer subsídios para a promoção de eventos de desenvolvimento das competências consideradas essenciais para os resultados da empresa;

- Estabelecer a estrutura de cargos e salários em conformidade com a complexidade das atividades envolvidas, com o nível de proficiência dos colaboradores, com os requisitos exigidos pelas atividades e com o mercado de trabalho. 
Deve-se notar que a elaboração do PCCR da Organização A teve como eixo orientador a missão e a visão de futuro da Organização $A$, além dos objetivos descritos em seu mapa estratégico. Esses compromissos estratégicos institucionais apoiaram a definição dos perfis profissionais necessários a um desempenho qualificado da Organização A, capaz de agregar os valores necessários ao cumprimento da missão institucional e ao alcance da visão de futuro no menor tempo possível.

O PCCR foi desenvolvido para ser utilizado, então, como um instrumento gerencial básico que possibilitasse a atração de profissionais com os perfis desejados e a sua retenção, além de criar os mecanismos que permitissem manter as equipes de trabalho capacitadas, valorizadas e comprometidas com os resultados esperados pela sociedade e pelo mercado.

Para a modelagem dos cargos, foi utilizado o conceito de multifuncionalidade. Sob esse entendimento, o compromisso de trabalho não se esgota em um elenco específico de atribuições, previamente estabelecido, voltado para uma única área de trabalho, mas sim em um conjunto amplo, polivalente e interdisciplinar de ações, correlacionado com várias áreas. Essa forma de estruturação permite uma maior mobilidade funcional que viabiliza, de um lado, melhores oportunidades de planejamento de carreiras pelos colaboradores e, de outro, um melhor aproveitamento dos profissionais pela Organização A, viabilizando:

- Flexibilidade e mobilidade na alocação dos colaboradores;

- Valorização dos colaboradores e das suas aptidões pessoais;

- Integração organizacional;

- Maximização do potencial das pessoas;

- Enriquecimento das atribuições;

- Crescimento profissional pela ampliação de atribuições.

A estrutura de cargos no PCCR desenvolvido é composta pelos seguintes grupos de cargos, segundo o nível de escolaridade: 
a) Nível Superior - Atividades que exigem curso completo correspondente à escolaridade de nível superior.

- Especialista em Projetos de Circuitos Integrados;

- Especialista em Tecnologia da Informação;

- Especialista em Fabricação de Circuitos Integrados;

- Especialista em Desenvolvimento de Produtos e Negócios;

- Analista em Gestão da Tecnologia Eletrônica Avançada.

b) Nível Médio - Atividades que exigem curso completo correspondente à escolaridade profissional técnica de nível médio.

- Técnico em Desenvolvimento e Fabricação de Circuitos Integrados.

c) Nível Médio - Atividades que exigem curso completo correspondente à escolaridade de nível médio.

- Técnico de Suporte Administrativo e Operacional.

Foi elaborada uma descrição dos cargos, constando as principais atribuições e responsabilidades dos profissionais ocupantes de cada cargo da Organização A. A descrição das principais atribuições e responsabilidades dos cargos por nível de complexidade constitui um referencial para seleção, treinamento, avaliação e outras atividades de gestão de pessoas da Organização A, sem, contudo, esgotar a amplitude ocupacional, pois envolve ainda atribuições e responsabilidades específicas da área de atuação do colaborador e pode, também, ser enriquecida a qualquer momento, por ato da Diretoria da empresa.

Para que houvesse um parâmetro para gerenciar o desenvolvimento do colaborador à medida do seu avanço no cargo, foram descritos os níveis de complexidade das principais atribuições e responsabilidades por cargo, os quais servirão como indicadores do desenvolvimento profissional do colaborador e da adequação da referência salarial percebida com a preparação ou potencial do colaborador em contribuir de maneira mais qualitativa para os resultados da Organização A.

As especificações dos cargos foram estabelecidas em duas dimensões: 
a) Ingresso na carreira - que considera os fatores:

- Habilitação em concurso público;

- Nível de escolaridade e sua comprovação;

- Qualificador que especificará o vínculo profissional de natureza especializada;

- Outros fatores considerados importantes e constantes do Edital do respectivo concurso público.

b) Evolução na carreira - que considera os requisitos de acesso, ou seja, o conjunto de condições que o colaborador deve atender para executar, com proficiência, as atribuições e as responsabilidades de uma determinada classe.

A estrutura salarial proposta pelo PCCR é composta por quatro tabelas contendo os padrões salariais atribuídos aos colaboradores da Organização A. As tabelas salariais dos cargos são compostas por:

a) Quatro classes salariais;

b) Cinco padrões salariais em cada classe.

Os valores fixados para os salários foram projetados para uma jornada de trabalho de quarenta horas semanais, com base nos valores praticados no mercado de trabalho de empresas privadas do setor de microeletrônica na época do presente estudo. Os valores apresentados a seguir, nas Tabelas 4.1, 4.2, 4.3 e 4.4, são fictícios, mas mantêm a proporcionalidade dos valores reais obtidos com a Organização A durante o estudo de caso. 


\section{a) Cargos de Nível Superior}

- Especialista em Projetos de Circuitos Integrados;

- Especialista em Tecnologia da Informação;

- Especialista em Fabricação de Circuitos Integrados;

- Especialista em Desenvolvimento de Produtos e Negócios.

Tabela 4.1 - Valores Salariais Mensais para Nível Superior - Especialistas

\begin{tabular}{|c|c|c|c|c|c|}
\hline Elasse & E1 & E2 & E3 & E4 & E5 \\
\hline ESPECIAL & $9.656,72$ & $9.898,14$ & $10.145,59$ & $10.399,23$ & $10.659,21$ \\
\hline III & $7.153,13$ & $7.331,95$ & $7.515,25$ & $7.703,14$ & $7.895,71$ \\
\hline II & $5.722,50$ & $5.865,57$ & $6.012,20$ & $6.162,51$ & $6.316,57$ \\
\hline I & $4.578,00$ & $4.692,45$ & $4.809,76$ & $4.930,00$ & $5.053,26$ \\
\hline
\end{tabular}

Obs: Valores fictícios, baseados nos valores reais.

\section{b) Cargos de Nível Superior}

- Analista em Gestão da Tecnologia Eletrônica Avançada.

Tabela 4.2 - Valores Salariais Mensais para Nível Superior - Analista

\begin{tabular}{|c|c|c|c|c|c|}
\hline Elasse & A1 & A2 & A3 & A4 & A5 \\
\hline ESPECIAL & $5.742,19$ & $5.885,74$ & $6.032,89$ & $6.183,71$ & $6.338,30$ \\
\hline III & $4.593,75$ & $4.708,59$ & $4.826,31$ & $4.946,96$ & $5.070,64$ \\
\hline II & $3.675,00$ & $3.766,88$ & $3.861,05$ & $3.957,58$ & $4.056,51$ \\
\hline I & $2.940,00$ & $3.013,50$ & $3.088,84$ & $3.166,06$ & $3.245,21$ \\
\hline
\end{tabular}

Obs: Valores fictícios, baseados nos valores reais. 


\section{c) Cargos de Nível Médio (escolaridade profissional técnica de nível médio)}

- Técnico em Desenvolvimento e Fabricação de Circuitos Integrados.

Tabela 4.3 - Valores Salariais Mensais para Nível Médio - Técnicos

\begin{tabular}{|c|c|c|c|c|c|}
\hline Classe & T1 & T2 & T3 & T4 & T5 \\
\hline ESPECIAL & $4.101,57$ & $4.204,10$ & $4.309,21$ & $4.416,94$ & $4.527,36$ \\
\hline III & $3.281,25$ & $3.363,28$ & $3.447,36$ & $3.533,54$ & $3.621,88$ \\
\hline II & $2.625,00$ & $2.690,63$ & $2.757,89$ & $2.826,84$ & $2.897,51$ \\
\hline I & $2.100,00$ & $2.152,50$ & $2.206,32$ & $2.261,47$ & $2.318,01$ \\
\hline
\end{tabular}

Obs: Valores fictícios, baseados nos valores reais.

\section{d) Cargos de Nível Médio}

- Técnico de Suporte Administrativo e Operacional

Tabela 4.4 - Valores Salariais Mensais para Nível Médio - Suporte e Operacional

\begin{tabular}{|c|c|c|c|c|c|}
\hline Classe & S1 & S2 & S3 & S4 & S5 \\
\hline ESPECIAL & $2.734,38$ & $2.802,74$ & $2.872,80$ & $2.944,62$ & $3.018,24$ \\
\hline III & $2.187,50$ & $2.242,19$ & $2.298,24$ & $2.355,70$ & $2.414,59$ \\
\hline II & $1.750,00$ & $1.793,75$ & $1.838,59$ & $1.884,56$ & $1.931,67$ \\
\hline I & $1.400,00$ & $1.435,00$ & $1.470,88$ & $1.507,65$ & $1.545,34$ \\
\hline
\end{tabular}

Obs: Valores fictícios, baseados nos valores reais.

O ingresso nos cargos deveria ocorrer mediante a aprovação prévia em concurso público de provas ou de provas e títulos, observadas as disposições legais, os requisitos dos cargos e ao que fosse estabelecido nos respectivos editais do concurso público. Poderia constar do concurso público curso de formação, dependendo da formação do candidato e de necessidade específica da empresa. O concurso público poderia ser realizado por áreas de especialização referentes à 
formação do candidato, conforme dispusesse o edital do concurso. A admissão seria efetivada sob o regime da Consolidação das Leis do Trabalho - CLT - e legislação complementar.

A movimentação dos colaboradores ocorreria por progressão, por promoção ou por enquadramento funcional, conforme critérios e processo estabelecidos pela Diretoria da Organização A. A progressão é a passagem do colaborador de um padrão salarial para outro, imediatamente superior, dentro da mesma Classe, podendo ocorrer por tempo de serviço ou por merecimento. A progressão por merecimento dependeria do posicionamento do colaborador em relação aos fatores de avaliação do mérito estabelecidos em norma pela Diretoria da Organização $A$, específicos a cada um dos cargos que compunham o PCCR desenvolvido.

A promoção, por sua vez, é a elevação do colaborador para a Classe imediatamente superior à ocupada, dentro do mesmo Cargo, dependendo do preenchimento dos requisitos de acesso estabelecidos em norma pela Diretoria da Organização A.

A Diretoria da empresa, com base em informação da área de gestão de pessoas, determinaria o número de vagas que deveria ser preenchido através da progressão e da promoção, considerando a limitação do impacto de 1,0\% (um por cento) sobre a folha salarial anual.

\section{Plano de Funções em Comissão (PFC)}

O Plano de Funções em Comissão (PFC) foi desenvolvido para complementar o PCCR, em apoio ao desenvolvimento e à valorização dos colaboradores, uma vez que tem a função de definir as regras para ocupação dos postos de direção e de assessoramento técnico-administrativo. Com o PFC, as amarras existentes na gestão do cargo poderiam ser amenizadas, ou eliminadas, pela utilização estratégica das funções em comissão. Isto porque a Organização A poderia, de maneira rápida, recrutar profissionais para trabalhos temporários e especializados, interna e externamente, assim como poderia destacar os colaboradores que adquirissem as condições para contribuir além das atribuições e responsabilidades do cargo ocupado. 
Em organizações em fase de implantação, como é o caso da Organização A, e ainda quando as atribuições envolvem atividades com tecnologia de ponta, competitivas e em rápida evolução, existe a necessidade de, temporariamente, recrutar pessoas detentoras de determinadas especialidades que possam, além de contribuir para a implantação da empresa, disseminar conhecimentos para o quadro de pessoal em formação. Por outro lado, a empresa precisaria implantar mecanismos que valorizassem os colaboradores que assumissem atribuições e responsabilidade que extrapolam os limites estabelecidos pelo cargo ocupado, adicionando valor aos seus resultados e atuando como um verdadeiro consultor de uma determinada especialidade. O PFC, portanto, consistia em um instrumento estratégico de gestão e poderia ser decisivo para que a Organização A, então, pudesse cumprir os seus planos, metas e compromissos assumidos em dotar o país dos conhecimentos e dos meios de desenvolvimento e produção de circuitos integrados.

Para o desenvolvimento do PFC, foram adotados os seguintes conceitos:

- Avaliação - consiste na verificação formal e sistemática dos resultados alcançados pelos colaboradores, comparados com os padrões de desempenho e de desenvolvimento estabelecidos;

- Captação de Pessoas - conjunto de procedimentos que visa atrair e selecionar candidatos potencialmente qualificados e capazes de ocupar Funções em Comissão na Organização A;

- Cargo - conjunto de ações e tarefas quanto à natureza do trabalho, à complexidade e às competências exigidas para sua execução. Os cargos são de natureza permanente, e acompanham a trajetória do profissional durante sua permanência na organização. Os cargos reúnem informações relacionadas à formação, experiência, conhecimento, situação funcional e processo seletivo requeridos; 
- Cargos em Comissão - são aqueles relacionados às atividades e responsabilidades pela gestão técnico-administrativa e pelo assessoramento técnico-administrativo à Diretoria e às Superintendências, a serem ocupados por pessoas não pertencentes aos quadros de pessoal da Organização A. Os cargos em comissão são de natureza temporária;

- Funções de Confiança - são aquelas relacionadas às atividades e responsabilidades pela gestão técnico-administrativa da Organização A e pelo assessoramento técnico-administrativo à Diretoria e às Superintendências da empresa, não cumulativas com outras funções, a serem ocupadas, exclusivamente, por colaboradores pertencentes ao quadro de pessoal efetivo da Organização A. As funções de confiança são de natureza temporária;

- Funções Gratificadas - são aquelas relacionadas à execução de atividades específicas, não cumulativas com outras funções, a serem ocupadas, exclusivamente, por colaboradores pertencentes ao quadro de pessoal efetivo da Organização A. As funções gratificadas são de natureza temporária;

- Funções em Comissão - postos de trabalho definidos como cargos em comissão, funções de confiança e funções gratificadas;

- Perfil das Funções em Comissão - descrição dos requisitos de escolaridade, experiência e competências necessárias ao desempenho de cada um dos cargos comissionados, funções de confiança e funções gratificadas existentes na empresa;

- Somatório das Rubricas de Natureza Trabalhista - Conjunto de valores representados pelo somatório do salário e parcelas adicionais de caráter permanente ou temporário;

- Valor de Referência - valor estabelecido em tabela salarial para remuneração da função em comissão.

Os objetivos específicos do PFC são:

- Promover a integração das ações de gestão de pessoas e a sua congruência com a missão, metas, planos e estratégias da empresa;

- Orientar as atividades de captação interna e externa de pessoas; 
- Estabelecer parâmetros a serem observados para o desempenho das atribuições inerentes a cada uma das funções em comissão praticados na Organização A;

- Oferecer parâmetro para que os colaboradores identifiquem o nível de prontidão individual para o exercício de funções em comissão e busquem adquirir todos os requisitos exigidos;

- Permitir aos colaboradores a visão de um horizonte profissional com critérios remuneratórios justos e equilibrados;

- Reconhecer as contribuições das pessoas para os resultados da empresa;

- Estimular o desenvolvimento e aperfeiçoamento de capacidades técnicas e gerenciais que contribuam para o alcance dos objetivos estratégicos da empresa.

O eixo orientador da elaboração do PFC foi o mesmo utilizado para 0 desenvolvimento do PCCR, envolvendo o direcionamento estratégico definido por meio da missão, da visão de futuro e dos objetivos descritos no mapa estratégico.

As funções em comissão foram estruturadas em eixos, de acordo com a natureza do trabalho a ser executado (gestão, técnico e assessoria e apoio) e conforme a expectativa do valor do trabalho a ser entregue. Essa expectativa foi explicitada na descrição das atribuições e responsabilidades dos Níveis de Complexidade das Funções em Comissão:

- Funções de Gestão - correspondem às atividades de gestão técnico administrativa da empresa;

- Funções Técnicas - correspondem às atividades de:

- Orientação técnica junto aos públicos internos e externos;

- Orientação e controle de atividades de caráter operacional ou técnico;

- Orientação de equipes de trabalho ou atividades especiais de supervisão, acompanhamento e fiscalização de projetos, convênios e contratos.

- Funções de Assessoria e Apoio - correspondem às atividades de assessoria ao Presidente, aos Diretores, aos Superintendentes e à execução de atividades de apoio administrativo e operacional às chefias. 
As funções em comissão, quanto à relação dos seus ocupantes com a empresa, foram classificadas em cargos em comissão, funções de confiança e funções gratificadas:

a) Cargos em Comissão - são aqueles relacionados às atividades e responsabilidades pela gestão técnico-administrativa da Organização $A$ e pelo assessoramento técnico-administrativo à Diretoria, Superintendências e Gerências, a serem ocupados por pessoas não pertencentes aos quadros de pessoal. Os cargos em comissão são de natureza temporária e envolvem os seguintes cargos:

- Gestão:

- Superintendente;

- Gerente de Departamento I;

- Gerente de Departamento II;

- Gerente de Divisão I;

- Gerente de Divisão II.

- Técnico:

- Consultor Técnico I;

- Consultor Técnico II;

- Consultor Técnico III.

- Assessoria e Apoio:

- Assessor da Presidência;

- Assessor de Diretoria;

- Assistente Técnico I;

- Assistente Técnico II;

- Assistente Técnico III;

- Secretaria da Presidência;

- Secretaria de Diretoria. 
b) Funções de Confiança - são aquelas relacionadas às atividades e responsabilidades pela gestão técnico-administrativa e pelo assessoramento técnico-administrativo, não cumulativas com outras funções, a serem ocupadas, exclusivamente, por colaboradores pertencentes ao quadro de pessoal efetivo da Organização A. As funções de confiança são de natureza temporária e envolvem as seguintes funções:

- Gestão:

- Superintendente;

- Gerente de Departamento I;

- Gerente de Departamento II;

- Gerente de Divisão I;

- Gerente de Divisão II.

- Assessoria e Apoio:

- Assessor da Presidência;

- Assessor de Diretoria;

- Secretaria da Presidência;

- Secretaria de Diretoria.

c) Funções Gratificadas - são aquelas relacionadas à execução de atividades específicas, não cumulativas com outras funções, a serem ocupadas, exclusivamente, por colaboradores pertencentes ao quadro de pessoal efetivo da Organização A. As funções gratificadas são de natureza temporária e envolvem as seguintes funções:

- Técnico:

- Consultor Técnico I;

- Consultor Técnico II;

- Consultor Técnico III;

- Auditor. 
- Assessoria e Apoio:

- Assistente Técnico I;

- Assistente Técnico II;

- Assistente Técnico III;

- Supervisor de Fábrica I;

- Supervisor de Fábrica II.

As funções em comissão teriam caráter situacional ou temporário e implicariam no exercício, em várias dimensões de complexidade e abrangência, nas diferentes áreas de atuação da empresa. O ocupante de uma função em comissão teria um papel fundamental na liderança e promoção de mudanças organizacionais que contribuíssem para o cumprimento da missão, dos planos e das estratégias organizacionais. O conteúdo das tarefas do trabalho comissionado, então, seria multidisciplinar, dinâmico e muitas vezes imprevisível, emergindo das necessidades atuais e futuras da empresa. Sob esse entendimento, igualmente aos cargos que compõem o PCCR, o compromisso de trabalho das pessoas que ocupam uma função em comissão não se esgotaria em um elenco específico de atribuições, previamente estabelecido, voltado para uma única área de trabalho, mas sim em um conjunto amplo, polivalente e interdisciplinar de ações, correlacionado com várias áreas. Essa forma de estruturação permitiria uma maior mobilidade funcional, viabilizando um melhor aproveitamento dos profissionais que ocupassem funções em comissão na Organização $A$.

A admissão para Cargos em Comissão seria efetivada sob o regime da Consolidação das Leis do Trabalho - CLT - e legislação complementar. A designação de colaborador para ocupar uma Função Gratificada seria precedida de processo seletivo interno, entre os candidatos que possuíssem os requisitos considerados mínimos para o exercício das atribuições e responsabilidades estabelecidas. Os ocupantes de Funções Gratificadas seriam submetidos à avaliação periódica do desempenho para confirmação da proficiência em continuar exercendo as atribuições e responsabilidades estabelecidas. O provimento, a renovação do provimento, o quantitativo e os requisitos a serem observados na seleção e demais procedimentos para ocupação de função em comissão deveriam ser estabelecidos em norma própria da empresa. 
A remuneração que foi sugerida para as Funções em Comissão foi baseada nos valores praticados no mercado de trabalho do setor de microeletrônica. Para fins de análise do caso, são apresentados na Tabela A (no Anexo A) os valores sugeridos. Deve-se notar que os valores apresentados são fictícios, porém estes mantêm a proporcionalidade dos valores reais obtidos com a Organização A durante o estudo de caso.

Os valores da remuneração das funções em comissão deveriam ser estabelecidos pela diretoria e submetidos à aprovação do Conselho de Administração da Organização A e dos órgãos de controle das empresas estatais. Periodicamente, e sempre que se mostrasse necessário, os valores da remuneração das funções em comissão deveriam ser corrigidos. O colaborador pertencente ao quadro efetivo da Organização A, ocupante de função em comissão, deveria receber complementarmente ao somatório de todas as rubricas de natureza trabalhista, o valor da diferença entre esse somatório e o estabelecido para o exercício da função em comissão ocupada, ou poderia optar pelo valor correspondente a $40 \%$ do valor estabelecido para o exercício da função em comissão ocupada.

Para que houvesse, sempre, colaboradores preparados para participarem dos processos seletivos para ocupação de função em comissão, a Organização A deveria estruturar um sistema que identificasse e que capacitasse as pessoas com aptidão para ocupação de tais posições comissionadas. Essa medida seria fundamental para que a empresa pudesse ganhar sustentabilidade no tempo e pudesse substituir as pessoas que deixassem as unidades sem causar transtornos ao andamento dos trabalhos e, se possível, também, agregar valor aos seus resultados.

\section{Regulamento de Progressão e Promoção}

Além do PCCR e do PFC desenvolvidos para a Organização A, foi elaborado o Regulamento de Progressão e Promoção da empresa, que visava definir as condições, as regras e os procedimentos relativos aos processos de progressão e promoção para os colaboradores da Organização A, aplicando-se a todos os 
colaboradores da empresa. As progressões e promoções deveriam ser feitas de acordo com as informações da área de recursos humanos, do chefe imediato e do próprio colaborador. De acordo com a legislação relacionada às empresas estatais, os colaboradores deveriam ser promovidos ou progredidos considerando a limitação do impacto de $1 \%$ sobre a folha salarial anual. O percentual estabelecido no item anterior seria aplicado da seguinte forma:

- $90 \%$ (noventa por cento) seriam aplicados, anualmente, nos processos de progressão por merecimento e de promoção;

- $10 \%$ (dez por cento) seriam aplicados, anualmente, nos processos de progressão por tempo de serviço;

- Do percentual definido no primeiro item, no mínimo, 10\% (dez por cento) seria aplicado no processo de progressão por merecimento.

A progressão seria concedida aos colaboradores nas seguintes modalidades:

- Merecimento;

- Tempo de serviço.

A progressão por merecimento corresponderia a um padrão salarial, dentro da mesma classe. A avaliação do merecimento do colaborador, para fins de progressão, seria determinada pela pontuação dos fatores de progressão por merecimento, correspondente ao interstício de avaliação. O interstício mínimo entre uma e outra ocorrência de progressão por merecimento deveria ser de vinte e quatro meses.

A progressão por tempo de serviço corresponderia a um padrão salarial, dentro da mesma classe. A avaliação do tempo de serviço do colaborador, para fins de progressão, seria determinada pelo tempo decorrido desde a última progressão por tempo de serviço do colaborador ou da sua última promoção, o que ocorrer por último. O interstício mínimo entre uma e outra ocorrência de progressão por tempo de serviço deveria ser de vinte e quatro meses.

Promoção, por sua vez, foi definida como a elevação do colaborador de uma classe para a primeira referência salarial da classe imediatamente superior do cargo 
ocupado. A promoção implicava que o colaborador estivesse apto ao exercício de atividades com maior nível de complexidade e responsabilidade, e poderia redundar na mudança da área de atuação, dependendo das carências identificadas. Os Requisitos de Acesso foram definidos como as certificações, os conhecimentos, as habilidades e demais condições, conforme constam no PCCR e no Regulamento de Progressão e Promoção, necessários à realização plena das atribuições inerentes ao cargo, com o nível de complexidade superior ao da classe ocupada. Quando atendidos, indicariam que o colaborador estava apto a se submeter ao processo de promoção. A qualquer tempo, o colaborador poderia informar que possuía conhecimentos, habilidades e demais condições que faziam parte dos requisitos de acesso às classes superiores à ocupada.

Para a avaliação dos colaboradores, deveriam ser criadas uma Comissão Central de Progressão e Promoção e Comissões Setoriais de Progressão e Promoção, com as responsabilidades definidas no Regulamento de Progressão e Promoção. A quantidade de Comissões Setoriais de Progressão e Promoção dependeria do número de colaboradores a serem avaliados, conforme decisão da Diretoria Executiva. Os colaboradores que seriam avaliados por uma determinada Comissão Setorial de Progressão e Promoção formariam um grupo base de avaliação. A classificação dos colaboradores para a promoção seria feita pelo total dos pontos do colaborador, somando-se os pontos obtidos com a avaliação de seu memorial com os pontos obtidos com a avaliação da proficiência do colaborador em exercer as atividades e responsabilidades da classe imediatamente superior à ocupada.

\section{Regulamento de Remuneração Variável e Gratificação de Desempenho}

Além do PCCR, do PFC e do Regulamento de Progressão e Promoção da empresa, foi desenvolvido um Regulamento de Remuneração Variável e Gratificação de Desempenho para os colaboradores da Organização A. Com a remuneração variável proposta, além dos benefícios, vantagens e adicionais definidos em legislação e em regulamentos da Diretoria da Organização A, a empresa concederia 
aos seus colaboradores uma verba remuneratória, denominada Gratificação de Desempenho. A Gratificação de Desempenho consistia em uma quantia variável a ser paga ao colaborador, sem incorporação desta à sua remuneração, como recompensa pelo alcance das metas definidas pela Diretoria da empresa.

A Gratificação de Desempenho seria devida aos colaboradores ocupantes de cargos efetivos da empresa, quando em exercício das suas atividades, e aos ocupantes de funções em comissão, até o limite máximo anual de três padrões salariais do colaborador. Para os colaboradores ocupantes de cargos efetivos, o padrão salarial a ser considerado para cálculo do pagamento da Gratificação de Desempenho teria o valor correspondente ao definido para o cargo, classe e padrão ocupado pelo colaborador no último dia do período avaliativo, mais o valor complementar que remuneraria a função em comissão ocupada. Para os colaboradores ocupantes de Cargo em Comissão, o padrão salarial a ser considerado para cálculo do pagamento da Gratificação de Desempenho teria o valor correspondente ao Valor de Referência do Cargo ocupado.

As metas e os indicadores de aferição do desempenho seriam estabelecidos pela Diretoria da Organização $A$, em negociação com o Conselho de Administração. Para cálculo da Gratificação de Desempenho deveriam ser utilizadas metas gerais para os indicadores de aferição, que envolveriam receita própria, custos da Organização $\mathrm{A}$ e mais dois outros indicadores estratégicos definidos pela Diretoria. Para cálculo do valor da Gratificação de Desempenho a ser pago, deveria ser considerado o percentual de concretização das atividades e das metas definidas e o valor relativo de cada uma das metas, conforme regulamento específico. O pagamento da Gratificação dependeria exclusivamente do alcance das metas globais definidas para a Organização A como um todo.

A Gratificação de Desempenho deveria ser atribuída aos colaboradores dos cargos efetivos da Organização A e colaboradores ocupantes de cargos em comissão. O valor máximo da Gratificação de Desempenho corresponderia a até três padrões salariais, com base na folha de pagamento do mês de novembro do período de mensuração das metas. O valor referente à Gratificação seria pago de forma proporcional, de acordo com o resultado global alcançado, da seguinte maneira: 
- Se o resultado global fosse inferior a 95\%, não haveria distribuição de gratificação;

- Se fosse alcançado resultado global de $95 \%$ até $97,49 \%$, o pagamento corresponderia a $25 \%$ do valor máximo da Gratificação;

- Se fosse alcançado resultado global de $97,50 \%$ até $99,99 \%$, o pagamento corresponderia a $50 \%$ do valor máximo da Gratificação; e

- Se fosse alcançado resultado global igual ou superior a $100 \%$, o pagamento corresponderia a $100 \%$ do valor máximo da Gratificação.

\subsection{Dimensão Processos}

A quarta dimensão do desenho organizacional que deve ser definida por uma organização é a dimensão Processos. Esta dimensão engloba o estudo da sequência de atividades que devem ser realizadas, incluindo a distribuição da informação por todos os envolvidos nos processos, o uso de tecnologia de informação adequada e o fornecimento de dados precisos (e relevantes) para os responsáveis dos processos. Nesta dimensão podem ser analisadas variáveis como diversidade, dificuldade e variabilidade de processos e subprocessos, formalização do processo, desempenho do processo, sistemas de informação, frequência de coleta de dados e escopo da base de dados.

A reestruturação da Organização $A$ envolveu o levantamento, a análise e a revisão da estrutura de macroprocessos e o desdobramento destes em processos e subprocessos. Os trabalhos envolveram a realização das seguintes atividades:

- Levantamento e Validação da Estrutura de Macroprocessos - esta atividade teve o objetivo de identificar os macroprocessos executados (ou que devem ser executados) pela Organização A;

- Desdobramento de Macroprocessos em Processos - esta atividade teve a finalidade de levantar e validar com as diversas áreas da Organização A a lista de processos de cada macroprocesso;

- Priorização de Processos para Levantamento e Revisão - esta atividade teve o objetivo de identificar os processos prioritários para levantamento e revisão; 
- Levantamento, Análise e Revisão de Processos - esta atividade englobou o levantamento, análise e revisão dos processos priorizados junto aos seus proprietários nas respectivas áreas da Organização $A$, bem como 0 levantamento da documentação e legislação associada a cada processo.

\section{Levantamento e Validação da Estrutura de Macroprocessos}

A Estrutura de Macroprocessos proposta corresponde a uma matriz formada pelos macroprocessos de negócio (na horizontal) e pelos macroprocessos de suporte (na vertical), apresentados na Figura 4.2: 


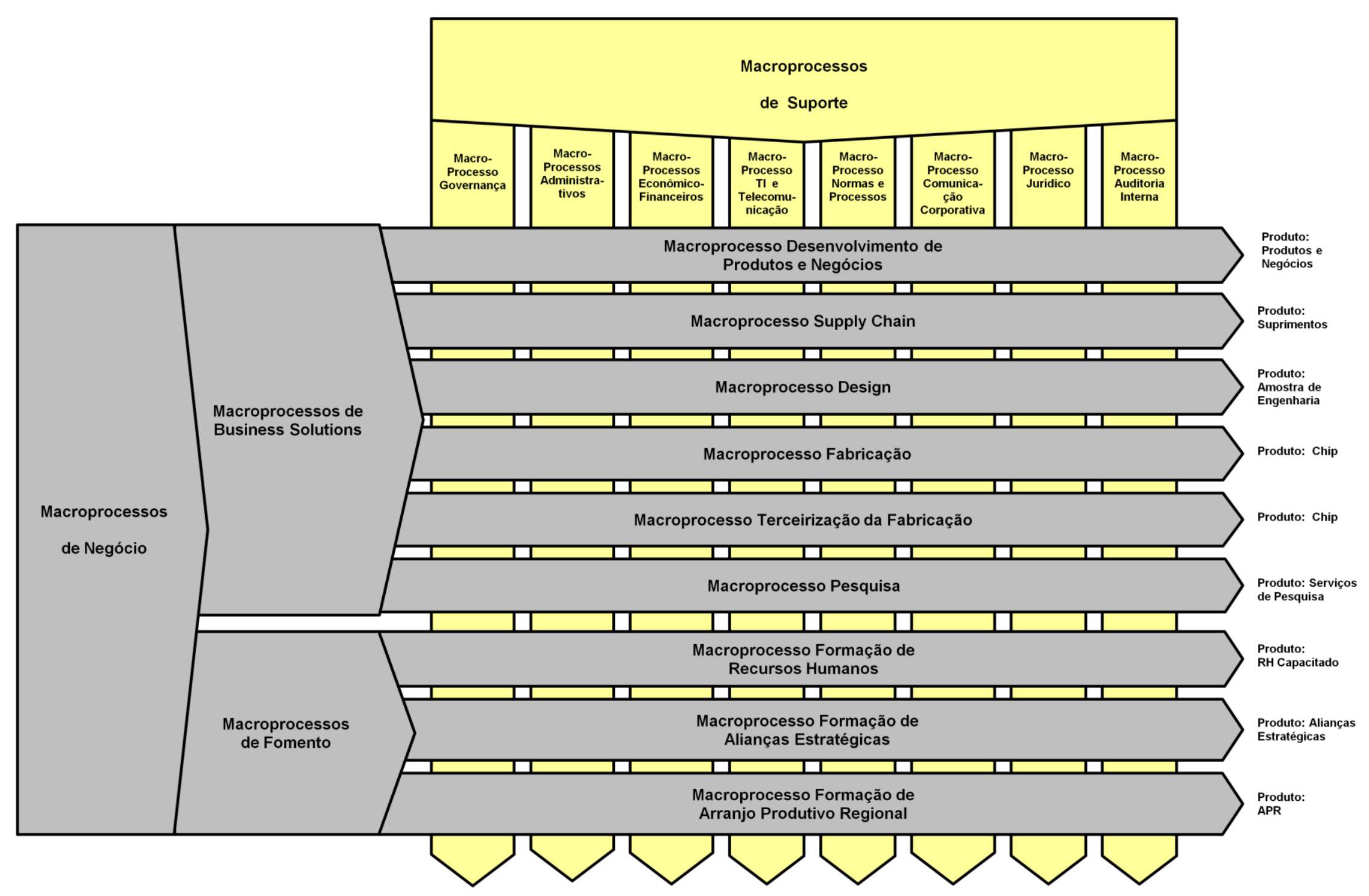

Figura 4.2 - Estrutura de Macroprocessos da Organização A (elaborada pela autora) 
Os macroprocessos podem ser definidos da seguinte forma:

- Macroprocessos de Negócios - abrangem processos que criam, produzem e fornecem bens ou serviços que os clientes desejam, ou seja, processos relacionados às atividades-fim da Organização $A$;

- Macroprocessos de Suporte - abrangem processos que dão apoio à realização dos macroprocessos de negócio.

$\mathrm{Na}$ estrutura de macroprocessos apresentada, cada macroprocesso de negócio é representado por uma faixa horizontal cinza. Por sua vez, as faixas verticais amarelas representam macroprocessos de suporte, que interagem com todos os macroprocessos de negócio da Organização $A$, dando apoio para que os mesmos sejam executados de forma efetiva. Deve-se notar que, de acordo com a teoria de processos, cada macroprocesso não representa uma área específica do organograma, uma vez que geralmente os processos atravessam diversas áreas, tendo atividades executadas por gestores e colaboradores de diferentes áreas.

Foram propostos dois conjuntos de Macroprocessos de Negócios, de forma a contemplar as dimensões estratégicas importantes derivadas da missão institucional da Organização A. Os conjuntos de macroprocessos de negócios são apresentados a seguir:

- Business Solutions - linha de negócio voltada para auxiliar empresas, fornecendo soluções de microeletrônica para inovação em negócios e desenvolvimento de modelos de negócios dessas empresas, agregando valor a produtos e serviços com base em aplicações de semicondutores. Engloba os macroprocessos:

- Desenvolvimento de Produtos e Negócios - envolve processos de prospecção e proposta de negócios, planejamento financeiro de operações e vendas, acompanhamento de negócios, fechamento de contratos e convênios, marketing, relações institucionais e atividades de pós-venda; 
- Supply Chain - envolve processos de identificação, seleção e avaliação de fontes de suprimento, desenvolvimento de fornecedores, gestão da malha logística e logística de assistência técnica, entre outros;

- Design - linha de negócio cujo produto final é a amostra de engenharia (projeto, design do chip);

- Fabricação - linha de negócio cujo produto final é o próprio chip;

- Terceirização da Fabricação - linha de negócio cujo produto final é o próprio chip por meio de fabricação por terceiros;

- Pesquisa - linha de negócio voltada especificamente para o desenvolvimento e pesquisa de novos produtos e tecnologias de fabricação e de processo, tendo inclusive o objetivo de formar parcerias com universidades e alianças estratégicas com governos e empresas.

- Fomento - linha de atuação voltada para desenvolver o setor de microeletrônica na região. Engloba os macroprocessos:

- Formação de Recursos Humanos - linha de atuação cuja finalidade é o desenvolvimento de mão de obra qualificada para atuar no setor de microeletrônica.

- Formação de Alianças Estratégicas - linha de atuação cuja finalidade é o desenvolvimento de parcerias com empresas do setor privado, instituições públicas, instituições de ensino, organizações comerciais, tanto nacionais como internacionais, com o objetivo de viabilizar a formação de um APR.

- Formação de Arranjo Produtivo Regional - linha de atuação cujo objetivo é o desenvolvimento de um APR do setor de microeletrônica.

Foram propostos os seguintes macroprocessos de Suporte para dar apoio aos macroprocessos de negócio: 
- Governança;

- Econômico-Financeiros:

- Orçamento e Finanças;

- Contabilidade;

- Administrativos:

- Compras e Importação;

- Gestão de Pessoas;

- Serviços Gerais de Apoio Administrativo;

- Tecnologia de Informação e Telecomunicação;

- Normas e Processos;

- Comunicação Corporativa;

- Jurídico;

- Auditoria Interna.

A estrutura obtida foi validada em dois momentos. Inicialmente, em reunião realizada com a presidência da Organização $A$, foi feita uma primeira validação da Estrutura de Macroprocessos. Com base nas sugestões obtidas na reunião de validação, e ainda com base em análise da legislação relacionada à criação da Organização $A$, foi construída uma segunda proposta de Estrutura de Macroprocessos, que foi validada em reunião realizada com a presença da presidência e da diretoria da Organização A.

\section{Desdobramento de Macroprocessos em Processos e Subprocessos}

Com base na Estrutura de Macroprocessos proposta, foi obtida uma lista de macroprocessos, sendo estes divididos em macroprocessos de negócios e macroprocessos de suporte. Cada macroprocesso foi desdobrado em processos (e subprocessos quando necessário), com a participação dos gestores de cada área. Foram elencados tanto processos e subprocessos já existentes na organização (identificados nos levantamentos), como processos e subprocessos propostos (ideais). A lista de processos e subprocessos obtida é apresentada no Anexo B. 


\section{Priorização de Processos para levantamento e revisão}

Em seguida, a lista de processos e subprocessos obtida foi priorizada, de modo a se identificarem os 36 processos para serem levantados, analisados e revisados em detalhe. A quantidade de processos (36) foi estabelecida arbitrariamente, considerando o prazo e a equipe disponíveis durante o projeto de reestruturação. Inicialmente, foram entrevistados os respectivos gestores dos processos (gestores das diversas áreas da Organização A), de modo a se identificar quais processos e subprocessos apresentavam prioridade do ponto de vista técnico. Os gestores das áreas pontuaram seus respectivos processos e subprocessos com notas de 1 a 5 ( 1 = muito essencial e 5 = pouco essencial). Esta análise apontou quais processos são muito essenciais para os trabalhos da Organização $A$, e quais são pouco essenciais, do ponto de vista técnico.

A seguir, foi realizada uma priorização do ponto de vista estratégico, utilizando como base o mapa estratégico e os objetivos estratégicos estabelecidos para a Organização A. Novamente, foi utilizada uma escala com notas variando de 1 a 5 . Esta priorização possibilitou identificar quais processos ou subprocessos apresentavam relevância estratégica alta $($ nota $=1)$ e relevância estratégica baixa $($ nota $=5)$.

Por fim, os resultados obtidos foram validados com o gestor da área de Qualidade, que identificou quais processos/subprocessos já apresentavam registro previamente elaborado, não sendo necessário priorizá-los para levantamento e revisão. A lista final de processos/subprocessos priorizados para levantamento e revisão é apresentada no Anexo $\mathrm{C}$.

\section{Levantamento, Análise e Revisão de Processos}

A seguir, cada processo ou subprocesso priorizado foi levantado, analisado e revisado em detalhe, em conjunto com seu respectivo gestor, sendo obtidos 36 Fluxogramas e Instruções de Trabalho (ITs). Em caso do processo priorizado para análise e revisão não ser ainda executado na Organização $A$ (processos ideais), sua sequência de atividades foi definida em conjunto com o gestor responsável, 
utilizando também como base informações de empresas semelhantes, conhecimento prévio da equipe de consultores e pesquisa bibliográfica. Para a elaboração dos fluxogramas e das ITs, foi utilizado o padrão estabelecido pela área de Qualidade da Organização A. Os fluxos e ITs obtidos constituem uma versão inicial, denominada Revisão 00, que deverá ser mantida e atualizada pela respectiva área responsável. Para cada processo, foram levantadas, inclusive, a legislação associada e os documentos (formulários, políticas, etc.) relacionados. Os fluxogramas e as ITs obtidos foram validados pelos respectivos proprietários (gestores das áreas da Organização A).

\subsection{Dimensão Estrutura Organizacional (Organograma)}

A quinta dimensão do desenho organizacional que deve ser definida por uma organização é a dimensão Estrutura Organizacional, geralmente expressa na forma de organogramas. Pode-se optar por diferentes modos de divisão do trabalho, departamentalização, configuração e distribuição de poder (grau de autonomia).

A estrutura geral que deveria ser adotada pela Organização $A$ encontra-se descrita em sua Lei de Criação. De acordo com esta lei, a estrutura deve apresentar: Conselho de Administração, Diretoria Executiva, Conselho Fiscal e Conselho Consultivo.

Ao Conselho de Administração compete, entre outros:

- Aprovar o regimento interno da Organização A, o qual detalharia as atribuições e as competências dos diretores, bem como a estrutura organizacional e seu funcionamento;

- Encaminhar ao Ministério de Ciência, Tecnologia e Inovação, para aprovação, o regulamento de licitação e contratação para aquisição de bens e realização de obras e serviços;

- Definir as normas específicas para contratação de pessoal permanente da Organização A por meio de concurso público de provas ou de provas e títulos.

Compete à Diretoria Executiva deliberar, para submissão do Conselho de Administração, sobre os seguintes aspectos, entre outros: 
- Estrutura da Organização A e seu plano organizacional;

- Aprovar as normas de planejamento, da organização e do controle dos serviços e atividades da Organização A.

Aos Diretores compete, entre outros:

- Responder por atividades ligadas ao planejamento estratégico da Organização A.

Ao Conselho Consultivo compete, entre outros:

- Opinar sobre as linhas gerais das políticas, diretrizes e estratégias da Organização A, orientando o Conselho de Administração e a Diretoria Executiva no cumprimento de suas atribuições;

- Assistir à Diretoria e ao Conselho de Administração em suas funções, sobretudo na formulação, implementação e avaliação das estratégias de ação da Organização.

O Conselho de Administração e a Diretoria Executiva seriam integrados por profissionais com experiência comprovada no setor de atuação da Organização A e notórios conhecimentos, inclusive sobre as práticas de governança corporativa.

Para o levantamento de informações iniciais mais detalhadas a respeito da estrutura organizacional, foi fornecido, pela área de Recursos Humanos, o organograma geral inicial, além dos organogramas iniciais dos setores Administrativo-Financeiro, Marketing, Design e Fábrica, apresentados, respectivamente, nos Anexos D, E, F, G e H ao final deste trabalho.

Observa-se que, embora previstos na lei de criação da Organização A, os Conselhos de Administração, Conselho Fiscal e Conselho Consultivo não aparecem nos organogramas fornecidos pela empresa.

Durante o projeto de reestruturação, foram propostas algumas alterações nos organogramas. A primeira alteração sugerida diz respeito à diretoria de Marketing, que foi substituída por uma Superintendência de Desenvolvimento de Produtos e Negócios. Apesar de existir uma proposta de organograma para uma Diretoria de Marketing, esta área, no início da reestruturação, não apresentava ainda quadro de pessoal preenchido. A criação da Superintendência de Desenvolvimento de 
Produtos e Negócios visava colocar a área em nível estratégico dentro da empresa, além de aumentar o escopo de atuação em relação à área de Marketing, uma vez que era, na época, imprescindível a busca por colocação dos produtos da Organização A no mercado, tanto de amostras de design como de chips, para permitir à empresa retorno financeiro.

Outra alteração que ocorreu durante a reestruturação está relacionada à Gerência de $\mathrm{TI}$, que foi elevada de gerência para Diretoria de Tecnologia de Informação e Telecomunicações (TITC) na estrutura, elevando o nível hierárquico da área. A proposta de alteração foi baseada na legislação pertinente (Instrução Normativa $N^{\circ} 4 / 2008$, da Secretaria de Logística e Tecnologia da Informação), que visa orientar as empresas estatais para a formação de Comitês de Tecnologia da Informação, para que se responsabilizem por alinhar os investimentos de $\mathrm{TI}$ com os objetivos da empresa e apoiar a priorização de projetos a serem atendidos, além de ser responsável pela segurança da informação. Em outras palavras, a diretoria da Organização A, considerando o papel estratégico que a área de TITC deveria tomar dentro da empresa, decidiu elevar o nível hierárquico da área. 


\section{ANÁLISE DO CASO}

Conforme apresentado inicialmente, um dos objetivos deste trabalho consiste em analisar o desenho organizacional de uma empresa pública brasileira do setor de semicondutores. O desenho organizacional a ser adotado por uma empresa depende das dimensões que o compõem, a saber, estratégia, pessoas, sistemas de recompensa, processos e estrutura. Todas estas dimensões devem estar alinhadas para se atingir o desempenho desejado, de forma que a organização se sustente ao longo do tempo e prospere.

Para a análise a ser feita neste estudo de caso será realizado, inicialmente, um corte temporal, avaliando a situação de cada dimensão do desenho organizacional antes da reestruturação descrita no caso, e os resultados obtidos (ou encaminhados) após o esforço de reestruturação da empresa. Em um segundo momento, será realizado um corte interdimensional na análise, com o objetivo de avaliar as interações entre as cinco dimensões do desenho organizacional e entre estas e o ambiente.

Por fim, será feita uma análise dos diversos subsistemas produtivos existentes na Organização A, assim como sua evolução ao longo do tempo.

O Quadro 5.1, apresentado a seguir, mostra um resumo dos principais resultados observados antes e após a reestruturação, para cada dimensão do desenho organizacional. 
Quadro 5.1 - Análise da Mudança nas Dimensões do Desenho Organizacional da Organização A

\begin{tabular}{|c|c|c|c|c|c|}
\hline & Estratégia & Pessoas & $\begin{array}{l}\text { Sistemas de } \\
\text { Recompensa }\end{array}$ & Processos & Estrutura \\
\hline $\begin{array}{c}\text { Situação } \\
\text { antes da } \\
\text { Reestruturação }\end{array}$ & $\begin{array}{l}\text { - Inexistência de } \\
\text { planejamento } \\
\text { estratégico }\end{array}$ & $\begin{array}{l}\text { - Pessoal } \\
\text { administrativo, de } \\
\text { Design e de Fábrica } \\
\text { com contrato } \\
\text { temporário ( } 24 \text { meses) }\end{array}$ & $\begin{array}{l}\text { - Tabela rígida e fixa } \\
\text { de salários } \\
\text { (temporário) }\end{array}$ & $\begin{array}{l}\text { - Existência de } \\
\text { procedimentos para } \\
\text { processos pontuais } \\
\text { (conforme demanda } \\
\text { por formalização) }\end{array}$ & $\begin{array}{l}\text { - Existência de } \\
\text { organogramas iniciais }\end{array}$ \\
\hline $\begin{array}{c}\text { Situação } \\
\text { após a } \\
\text { Reestruturação }\end{array}$ & $\begin{array}{l}\text { - Definição de missão } \\
\text { e visão da empresa } \\
\text { - Elaboração do mapa } \\
\text { estratégico } \\
\text { - Definição de metas e } \\
\text { objetivos estratégicos } \\
\text { - Definição de } \\
\text { indicadores } \\
\text { estratégicos }\end{array}$ & $\begin{array}{l}\text { - Definição de } \\
\text { dimensionamento de } \\
\text { pessoal } \\
\text { - Definição de cargos } \\
\text { necessários e } \\
\text { respectivas atribuições } \\
\text { - Elaboração de edital } \\
\text { para Concurso Público } \\
\text { - Elaboração de } \\
\text { Regulamento de } \\
\text { Pessoal }\end{array}$ & $\begin{array}{l}\text { - Criação do PCCR } \\
\text { - Criação do PFC } \\
\text { - Elaboração } \\
\text { Regulamento de } \\
\text { Progressão e } \\
\text { Promoção } \\
\text { - Elaboração do } \\
\text { Regulamento de } \\
\text { Remuneração Variável } \\
\text { e Gratificação de } \\
\text { Desempenho }\end{array}$ & $\begin{array}{l}\text { - Elaboração da Matriz } \\
\text { de Macroprocessos } \\
\text { - Inclusão do } \\
\text { Macroprocesso } \\
\text { Fomento } \\
\text { - Levantamento da } \\
\text { lista de processos e } \\
\text { subprocessos } \\
\text { - Elaboração de } \\
\text { fluxogramas de } \\
\text { processos e de } \\
\text { procedimentos para } \\
\text { processos críticos }\end{array}$ & $\begin{array}{l}\text { - Criação da área de } \\
\text { "Produtos e Negócios" } \\
\text { - Elevação da área de } \\
\text { TITC na hierarquia }\end{array}$ \\
\hline $\begin{array}{c}\text { Impacto da } \\
\text { Reestruturação }\end{array}$ & $\begin{array}{c}\text { Resultados positivos - } \\
\text { Missão e visão } \\
\text { definidas, objetivos } \\
\text { estratégicos } \\
\text { divulgados a todos no } \\
\text { mapa estratégico }\end{array}$ & $\begin{array}{l}\text { Resultados positivos - } \\
\text { Cargos definidos; } \\
\text { Elaboração de } \\
\text { concurso público para } \\
\text { efetivação de pessoal } \\
\text { em andamento }\end{array}$ & $\begin{array}{l}\text { Resultados positivos - } \\
\text { Propostas aprovadas } \\
\text { pelos órgãos } \\
\text { competentes }\end{array}$ & $\begin{array}{l}\text { Resultados positivos - } \\
\text { Definição e } \\
\text { Mapeamento de } \\
\text { processos prioritários }\end{array}$ & $\begin{array}{c}\text { Resultados positivos - } \\
\text { Pequenas propostas } \\
\text { de mudança }\end{array}$ \\
\hline
\end{tabular}

Fonte: Elaborado pela autora. 


\subsection{Análise da Dimensão Estratégia}

Analisando a dimensão Estratégia do desenho organizacional, observa-se que a Organização A não apresentava inicialmente sua estratégia de atuação definida, e nem planejamento estratégico elaborado. A empresa demandava, portanto, com urgência, a definição de sua estratégia e elaboração de seu planejamento estratégico, de forma a definir as metas e objetivos a serem alcançados, norteando as atividades da organização. A reestruturação realizada teve como uma das atividades iniciais a condução de várias etapas - Revisão da Estratégia, Construção do Mapa Estratégico, Definição de Indicadores de Desempenho Estratégicos, Definição e Gerenciamento de Metas Estratégicas, Definição de Projetos Estratégicos - que resultaram na definição do planejamento estratégico da Organização A. Foram definidas, também, as atividades a serem executadas para a Análise Periódica da Estratégia, de modo a facilitar sua revisão ao longo do tempo. A reestruturação, portanto, apresentou resultados altamente positivos com relação à dimensão Estratégia. Segundo Greasley (2004), que aplicou a metodologia do BSC associada a mapeamento de processos em instituições públicas no Reino Unido, a aplicação do BSC assegura que os processos corretos serão identificados e redesenhados no nível operacional, de forma a sustentar os objetivos estratégicos da organização. Além disso, a metodologia utiliza sistemas de medidas de desempenho para verificar se as mudanças implantadas realmente alcançam o efeito desejado ao longo do tempo.

Deve-se notar que, embora os projetos estratégicos tenham sido aprovados pelos gestores e diretores da Organização A, no sentido de se alcançar os objetivos definidos no mapa estratégico, fica para a empresa a grande tarefa de gerenciar e executar tais projetos. Considerando que, na época, a organização apresentava um quadro de pessoal temporário e incompleto, inclusive para a execução de suas atividades de rotina, a execução e o gerenciamento de tais projetos estratégicos ficaria particularmente dificultada. Uma sugestão que foi apresentada consistia na criação de um escritório de projetos, a ser incluído na estrutura formal da empresa, que ficaria responsável pela atividade de gerenciamento. A execução de cada projeto seria realizada ou por equipes temporárias internas (formadas por meio de 
funções em comissão), ou por fornecedores terceirizados, observados os trâmites legais de contratação.

\subsection{Análise da Dimensão Pessoas}

A dimensão Pessoas da Organização A apresentava, na época do presente estudo, urgência com relação à definição da situação dos colaboradores, que trabalhavam com base em contrato temporário, o que gerava significativa instabilidade no quadro de pessoal. Durante a reestruturação, foram desenvolvidas quatro ações, a saber: (1) Dimensionamento de pessoal, para balizar a elaboração do Plano de Cargos, Carreiras e Remuneração (PCCR), (2) Definição de cargos necessários e respectivas atribuições, também para apoiar a elaboração do PCCR, (3) Encaminhamento do Concurso Público para efetivação de pessoal e preenchimento de cargos ainda vagos, e (4) Elaboração do Regulamento de Pessoal. Percebe-se que a reestruturação apresentou resultados altamente positivos com relação à dimensão Pessoas, uma vez que foram encaminhadas questões urgentes para a gestão de pessoas da empresa.

Deve-se notar, entretanto, que, na época do presente estudo, o dimensionamento de pessoal, assim como os cargos propostos, estava em fase de análise pelos órgãos de controle das empresas estatais.

\subsection{Análise da Dimensão Sistemas de Recompensa}

Assim como a dimensão Pessoas, a dimensão Sistemas de Recompensa da Organização A demandava ações urgentes. Durante a reestruturação, foram desenvolvidas quatro ações, a saber: (1) Definição do Plano de Cargos, Carreiras e Remuneração (PCCR), (2) Definição do Plano de Funções em Comissão (PFC), (3) Elaboração do Regulamento de Progressão e Promoção, e (4) Elaboração do Regulamento de Remuneração Variável e Gratificação de Desempenho. Percebe-se que a reestruturação apresentou resultados altamente positivos com relação à 
dimensão Sistemas de Recompensa, uma vez que foram encaminhadas questões urgentes para a gestão de pessoas da empresa.

Deve-se notar, novamente, que, na época do presente estudo, o PCCR, assim como PFC e os Regulamentos de Progressão e Promoção e de Remuneração Variável e Gratificação de Desempenho, foram aprovados pelos órgãos de controle das empresas estatais.

\subsection{Análise da Dimensão Processos}

Com relação à dimensão Processos, antes da reestruturação a Organização A apresentava alguns poucos procedimentos descritos, relacionados a demandas pontuais. Durante a reestruturação da empresa, foi identificada a lista de macroprocessos, processos e subprocessos, sendo construída a matriz de macroprocessos da empresa. Após priorização dos processos, aqueles considerados mais críticos foram mapeados e tiveram seus procedimentos descritos, o que pode ser considerado um resultado positivo em relação à dimensão Processos. No caso específico do processo de Compras, foi efetuado um estudo mais aprofundado, visando levantar todas as necessidades relacionadas à legislação vigente para as empresas estatais, além de treinar e tirar as dúvidas dos colaboradores que atuavam nesse processo. Vale citar, também, o encaminhamento do Concurso Público, detalhado na dimensão "Pessoas", que consiste na etapa inicial do processo de Recrutamento e Seleção dentro de uma empresa estatal.

Observa-se que, na lista de processos identificados, além dos processos que já eram executados pela Organização $A$, foram incluídos os macroprocessos "Pesquisa" e "Fomento", este último abrangendo os processos "Formação de Recursos Humanos", "Formação de Alianças Estratégicas" e "Formação de Arranjo Produtivo Regional". Apesar destes macroprocessos ainda não serem executados pela empresa de modo formal, os mesmos constam em sua lei de criação como atividades que deveriam ser executadas, em algum momento, pela Organização A.

Outro ponto que vale ser citado diz respeito a Vendas. Embora as atividades de vendas estejam incluídas no macroprocesso Desenvolvimento de Produtos e Negócios, seria recomendável criar um macroprocesso específico para Vendas, uma 
vez que no momento do presente estudo a Organização A tinha grande necessidade de obter recursos financeiros para sua autossustentação.

Deve-se notar, no entanto, que o levantamento da lista de processos e a elaboração dos procedimentos mais críticos realizados durante a reestruturação constituiu apenas um esforço inicial para a reorganização e definição da dimensão Processos. Seria recomendável que a Organização A despendesse mais tempo para mapear de forma detalhada seus processos, integrando as atividades das diversas áreas e proporcionando uma visão matricial (Áreas $x$ Processos). Esta integração entre as áreas não chegou a ser executada durante a reestruturação, uma vez que o levantamento focou principalmente na sequência de atividades dentro de cada área, para a elaboração de procedimentos operacionais.

\subsection{Análise da Dimensão Estrutura Organizacional}

Analisando a dimensão Estrutura Organizacional, antes do projeto de reestruturação, a Organização $A$ já possuía um organograma definido, conforme apresentado na descrição do caso. Ao longo da reestruturação, entretanto, foram propostas algumas alterações, no sentido de adequar a estrutura aos processos que deveriam ser executados para se atingir os objetivos estratégicos da empresa. Entre as alterações no organograma, pode-se citar a criação da área de "Desenvolvimento de Produtos e Negócios", inicialmente inexistente, que passou a substituir a área de "Marketing", porém com atribuições mais abrangentes.

Outra alteração que se mostrou necessária está relacionada à área de "Tecnologia de Informação e Telecomunicações", que foi alçada de gerência para diretoria na estrutura, elevando o nível hierárquico da área. Esta alteração foi justificada com base em legislação (Instrução Normativa $N^{\circ} 4 / 2008$, da Secretaria de Logística e Tecnologia da Informação), que visa orientar as empresas estatais para a formação de Comitês de Tecnologia da Informação, para que se responsabilizem por alinhar os investimentos de TI com os objetivos da empresa e apoiar a priorização de projetos a serem atendidos. A diretoria da Organização $A$, considerando o papel estratégico que a área de TITC deveria tomar dentro da empresa, decidiu elevar o nível hierárquico da área. 
É recomendável, entretanto, que a Organização A faça uma revisão de todos os macroprocessos e processos que devem ser executados, conforme foram definidos na matriz de macroprocessos e na lista de processos e subprocessos, visando cruzar os organogramas das diversas áreas e verificar se todas as atividades estão realmente alocadas, apresentando colaboradores responsáveis por sua execução. É importante, principalmente, identificar aqueles processos que ainda não são executados, mas que constam na missão da empresa, e definir quais áreas e quais colaboradores serão responsáveis, ou criar novas áreas e cargos para tais funções.

\subsection{Interação entre as Dimensões do Desenho Organizacional}

Segundo o modelo de desenho organizacional proposto por Galbraith, conhecido como "modelo da estrela" (GALBRAITH, 1977; GALBRAITH, 1994; KATES e GALBRAITH, 2007; GALBRAITH, 2009), esquematizado na Figura 2.3, uma organização deve fazer opções nos elementos ou dimensões de seu desenho organizacional para atingir seus objetivos, ou seja, deve definir as dimensões Estratégia, Pessoas, Sistemas de Recompensa, Processos e Estrutura, visando obter alinhamento entre estas dimensões. Galbraith deixa claro que estas diferentes dimensões são interdependentes e interagem entre si; ao se alterar uma determinada dimensão, as demais dimensões sentirão o impacto desta alteração, sendo possivelmente alteradas também. É importante notar que as interações do desenho organizacional de uma empresa ocorrem não somente entre as dimensões internas da organização, mas também entre estas dimensões e o ambiente em que a organização atua, seja ele ambiente legal, físico, político, do mercado ou do setor de atuação da empresa, conforme foi proposto e esquematizado na Figura 2.11.

Visando analisar a interação entre as cinco dimensões de desenho organizacional da Organização A, e entre estas e o ambiente, foi construído o Quadro 5.2, apresentado a seguir. 
Quadro 5.2 - Interação entre as Dimensões dos Subsistemas Produtivos da Organização A

\begin{tabular}{|c|c|c|c|c|c|c|}
\hline & Ambiente & Estratégia & Pessoas & $\begin{array}{l}\text { Sistemas de } \\
\text { Recompensa }\end{array}$ & Processos & Estrutura \\
\hline Ambiente & & $\begin{array}{l}\text { - Lei de Criação } \\
\text { - Definição de missão e } \\
\text { visão da empresa } \\
\text { - Elaboração do mapa } \\
\text { estratégio } \\
\text { - Definição de metas, } \\
\text { objetivos e indicadores } \\
\text { estratégicos }\end{array}$ & $\begin{array}{l}\text { - Necessidade de } \\
\text { Concurso Público para } \\
\text { efetivar colaboradores } \\
\text { temporários } \\
\text { - Necessidade } \\
\text { estabilização do quadro } \\
\text { de pessoal em um } \\
\text { mercado aquecido }\end{array}$ & $\begin{array}{l}\text { - Necessidade de } \\
\text { seguir regras do setor } \\
\text { público } \\
\text { - Mercado de trabalho } \\
\text { aquecido, com altos } \\
\text { salários em setores de } \\
\text { alta tecnologia }\end{array}$ & $\begin{array}{l}\text { - Necessidade de } \\
\text { seguir procedimentos } \\
\text { pré-definidos para } \\
\text { organizações públicas } \\
\text { - Inclusão de processos } \\
\text { para seguir lei de } \\
\text { criação }\end{array}$ & $\begin{array}{l}\text { - Necessidade de } \\
\text { estruturar a empresa } \\
\text { com base em legislação } \\
\text { (lei de criação) }\end{array}$ \\
\hline Estratégia & & & $\begin{array}{l}\text { - Definição de cargos } \\
\text { com base nos objetivos } \\
\text { estratégicos } \\
\text { estabelecidos }\end{array}$ & $\begin{array}{l}\text { - PCCR e PFC } \\
\text { flexíveis, alinhados com } \\
\text { o mapa estratégico } \\
\text { - Definição de salários } \\
\text { com base nos valores } \\
\text { praticados no mercado }\end{array}$ & $\begin{array}{l}\text { - Inclusão dos } \\
\text { macroprocessos } \\
\text { Pesquisa e Fomento, } \\
\text { para alcançar objetivos } \\
\text { estratégicos }\end{array}$ & $\begin{array}{l}\text { - Criação de um } \\
\text { Escritório de Projetos } \\
\text { - Elevação da área de } \\
\text { TITC na hierarquia }\end{array}$ \\
\hline Pessoas & & & & $\begin{array}{l}\text { - Criação do PCCR } \\
\text { - Criação do PFC } \\
\text { - Regulamento de } \\
\text { Progressão e } \\
\text { Promoçãa }\end{array}$ & $\begin{array}{l}\text { - Match entre cargos e } \\
\text { processos } \\
\text { - Definição do processo } \\
\text { de Recrutamento e } \\
\text { Seleção por Concurso } \\
\text { Público }\end{array}$ & $\begin{array}{l}\text { - Elaboração do } \\
\text { dimensionamento de } \\
\text { pessoal (conforme áreas } \\
\text { da estrutura) }\end{array}$ \\
\hline $\begin{array}{l}\text { Sistemas de } \\
\text { Recompensa }\end{array}$ & & & & & $\begin{array}{l}\text { - PCCR e PFC } \\
\text { flexíveis, apoiando a } \\
\text { criação de novos } \\
\text { processos (ambiente } \\
\text { de alta tecnologia) }\end{array}$ & $\begin{array}{l}\text { - PCCR e PFC flexíveis, } \\
\text { apoiando a criação de } \\
\text { novas áreas }\end{array}$ \\
\hline Processos & & & & & & $\begin{array}{l}\text { - Necessidade de match } \\
\text { entre áreas e processos } \\
\text { (p.e. criação de áreas } \\
\text { responsáveis pelos } \\
\text { processos de Pesquisa e } \\
\text { Fomento, criação de área } \\
\text { para Serviços Gerais) }\end{array}$ \\
\hline Estrutura & & & & & & \\
\hline
\end{tabular}

Fonte: Elaborado pela autora 


\section{Interação Ambiente - Estratégia:}

Ao analisar a interação do ambiente da Organização $A$ com a dimensão Estratégia, o primeiro aspecto que chama a atenção é a existência de uma Lei de Criação, que apresenta grande impacto em sua missão organizacional. Analisando o texto da Lei de Criação, observa-se que as atividades que deveriam competir à Organização A envolvem um espectro bastante amplo, incluindo produção de bens, desenvolvimento e difusão tecnológica, produção de serviços especializados de laboratório, desenvolvimento de produtos, atração de investimentos regionais, formação e capacitação de recursos humanos (função de instituição de ensino), entre outros. Este amplo espectro de atividades afetou significativamente a definição de sua missão e visão de futuro, além de impactar na construção do mapa estratégico e dos objetivos, metas e indicadores. Ao analisar os objetivos estratégicos descritos no mapa, no entanto, percebe-se que há uma ênfase maior na função de produção de bens (chips), fato que pode ser explicado pela preocupação da Organização A, na época do presente estudo, em consolidar seu subsistema "Fabricação" e tornar-se autossuficiente financeiramente.

\section{Interação Ambiente - Pessoas:}

Um dos aspectos do ambiente que afeta a dimensão Pessoas da Organização A consiste na existência de legislação trabalhista específica para o setor público brasileiro, que estabelece que o processo de seleção deve ocorrer por Concurso Público. Diante desta exigência do setor público, surge a necessidade de realização de concurso para efetivação do quadro temporário de pessoal, contratado por um período de 24 meses para a implantação inicial da empresa.

Outro aspecto relevante diz respeito ao ambiente de mercado que, na época do presente estudo, apresentava-se bastante aquecido no Brasil, com falta de mão de obra qualificada, principalmente em um setor de alta tecnologia, como é o caso dos semicondutores.

Estes dois aspectos do ambiente apresentavam forte impacto na dimensão Pessoas, gerando instabilidade no quadro de pessoal. 


\section{Interação Ambiente - Sistemas de Recompensa:}

O principal aspecto do ambiente da Organização A consiste no fato desta ser uma empresa pública, aplicando-se sobre seu quadro de colaboradores (concursados), portanto, todas as regras relativas ao setor público, incluindo estabilidade empregatícia. As regras a serem seguidas pelo setor são estabelecidas e geridas por órgãos centrais da União, no caso, o DEST (Departamento de Coordenação e Governança das Empresas Estatais). Qualquer alteração das regras vigentes sobre o sistema de recompensa da Organização $A$, visando adequar a dimensão Sistemas de Recompensa de seu desenho organizacional, deveria ser submetida à aprovação deste órgão central.

Outra questão a ser destacada consiste na situação do mercado de trabalho no Brasil, que na época do presente estudo, encontrava-se bastante aquecido, com falta de mão de obra qualificada, o que gerava um aumento relativo dos níveis salariais, principalmente em setores de alta tecnologia, como é o caso do setor de semicondutores. No caso da Organização A havia, inclusive, necessidade de buscar mão de obra especializada no exterior, o que exigia salários e condições de trabalho atrativos também para colaboradores externos.

\section{Interação Ambiente - Processos:}

A Organização A sofre impacto do ambiente principalmente em seus processos administrativos, uma vez que existe a necessidade de seguir procedimentos pré-definidos para organizações públicas. Como exemplos, pode-se citar o processo de Compras, com impacto direto na fabricação (portanto o ambiente também impacta nos processos de negócio), que deve seguir legislações como a lei 8.666 de 21/06/93, que estabelece normas gerais sobre licitações e contratos administrativos pertinentes a obras, serviços, inclusive de publicidade, compras, alienações e locações no âmbito dos Poderes da União, dos Estados, do Distrito Federal e dos Municípios.

Outro processo que apresenta grande influência do ambiente do setor público é o de Planejamento Orçamentário, que deve ser realizado conforme os trâmites da 
esfera pública, com aprovação pelo Ministério da Ciência, Tecnologia e Inovação e pelo Congresso Nacional.

A Lei de Criação da Organização A, que lista o espectro de atividades que devem ser exercidas, também influencia o conjunto de processos que devem ser executados. Na época do estudo de caso, observou-se que alguns processos descritos na Lei ainda não eram executados, como era o caso dos processos de fomento e de pesquisa.

\section{Interação Ambiente - Estrutura:}

A estrutura geral que deveria ser adotada pela Organização A também se encontra descrita em sua Lei de Criação, portanto faz parte do ambiente de empresa pública. De acordo com esta lei, a estrutura deveria apresentar: Conselho de Administração, Diretoria Executiva, Conselho Fiscal e Conselho Consultivo. A Lei descreve inclusive as atividades que competem a cada um destes órgãos.

Do ponto de vista do mercado, o ambiente de atuação da Organização A é caracterizado por um alto dinamismo e competição, como é o caso do setor de semicondutores. Visando fazer frente a esta situação, e ainda com o objetivo de incentivar os negócios, foram propostas alterações no organograma da empresa, no sentido de adequar a estrutura aos objetivos estratégicos da empresa. Entre as alterações, pode-se citar a criação da área de "Desenvolvimento de Produtos e Negócios".

\section{Interação Estratégia - Pessoas:}

Um aspecto relacionado à interação da dimensão Estratégia com a dimensão Pessoas consiste na utilização da missão e da visão de futuro da Organização A, além dos objetivos descritos em seu mapa estratégico, como eixo orientador para a definição de cargos e funções englobadas no PCCR e no PFC da Organização A. Esses compromissos estratégicos institucionais apoiaram a definição dos perfis profissionais necessários a um desempenho qualificado da Organização A, capaz de 
agregar os valores necessários ao cumprimento da missão institucional e ao alcance da visão de futuro no menor tempo possível.

O PCCR e o PFC foram desenvolvidos para serem utilizados, então, como instrumentos gerenciais básicos que possibilitassem a atração de profissionais com os perfis desejados e a sua retenção, além de criar os mecanismos que permitissem manter as equipes de trabalho capacitadas, valorizadas e comprometidas com os resultados esperados pela sociedade e pelo mercado.

\section{Interação Estratégia - Sistemas de Recompensa:}

Assim como a definição de cargos e funções, a definição de salários e benefícios teve como eixo norteador a missão, a visão de futuro e os objetivos descritos no mapa estratégico da Organização $A$, além adotar como base os salários praticados no mercado do setor de semicondutores. Deve-se notar que, ao ser proposto o PFC, foi dada especial ênfase à flexibilidade para o quadro de colaboradores, necessária para a nomeação de funções específicas. Em um ambiente de alta inovação e concorrência, como é o caso do setor de semicondutores, é preciso ter a possibilidade de suprir rapidamente funções estratégicas, seja com pessoal interno, seja com especialistas externos, visando obter as competências necessárias às operações da empresa. No caso de um colaborador interno da Organização $A$, o fato de poder gratificar financeiramente o exercício de uma função destacada representa um fator significativo para o aumento da motivação do pessoal.

\section{Interação Estratégia - Processos:}

A interação entre a dimensão estratégia e a dimensão processos pode ser observada na construção da estrutura de macroprocessos da Organização A. Notase que os objetivos estratégicos do mapa refletem-se nos macroprocessos propostos, incluindo a proposta dos macroprocessos de Fomento - Formação de Recursos Humanos, Formação de Alianças Estratégicas e Formação de Arranjo 
Produtivo Regional - além do macroprocesso de Pesquisa, macroprocessos estes que ainda não estavam sendo executados formalmente, mas que deveriam ser postos em prática de forma regular para alcançar os objetivos estratégicos e fazer cumprir a missão descrita na Lei de Criação para a Organização A.

\section{Interação Estratégia - Estrutura:}

Ao ser construído o mapa estratégico da Organização $A$, foram elencados vários projetos estratégicos, cada um deles visando alcançar um objetivo estratégico descrito no mapa. Para gerenciar o andamento de um número significativo de projetos, foi proposta a criação de um escritório de projetos, a ser incluída na estrutura da Organização A. Tal proposta ainda não havia sido aprovada, na época do estudo.

Outro aspecto que evidencia a interação entre a dimensão estratégia e a estrutura está relacionado à elevação da área de Tecnologia de Informação e Telecomunicações de gerência para diretoria na estrutura, considerando a importância estratégica que a área de TITC deveria tomar dentro da empresa.

\section{Interação Pessoas - Sistemas de Recompensa:}

A interação da dimensão Pessoas com a dimensão Sistemas de Recompensa da Organização A pode ser observada no desenvolvimento do Plano de Cargos, Carreiras e Remuneração (PCCR), do Plano de Funções em Comissão (PFC), na elaboração do Regulamento de Progressão e Promoção e na elaboração do Regulamento de Remuneração Variável e Gratificação de Desempenho.

\section{Interação Pessoas - Processos:}

Um aspecto que deve ser analisado na interação entre a dimensão Pessoas e a dimensão Processos é o match entre cargos e processos, ou seja, a congruência 
entre as pessoas que executam as tarefas na sequência de atividades de cada processo, tanto para processos de negócio como para processos de suporte. Segundo a teoria sócio-técnica de Emery e Trist (EMERY, 1969), é impossível gerenciar o sistema técnico, formado por recursos e componentes físicos e abstratos, como objetivos, divisão do trabalho, tecnologia, instalações e procedimentos, sem considerar o sistema social, formado por todas as manifestações de comportamento dos indivíduos e dos grupos, como relações sociais, grupos informais, cultura, clima, atitudes e motivação.

Um ponto específico da interação de pessoas e processos consiste na própria definição do processo de Recrutamento e Seleção, que, no caso da Organização A, deveria ocorrer por meio de concurso público. O processo em questão, na época do estudo, encontrava-se em fase de definição de sua sequência de atividades e elaboração de Edital.

\section{Interação Pessoas - Estrutura:}

A interação da dimensão Pessoas com a dimensão Estrutura pode ser observada no dimensionamento de pessoal realizado para cada área, conforme apresentado nos organogramas obtidos durante o estudo de caso.

\section{Interação Sistemas de Recompensa - Processos:}

O desenvolvimento do Plano de Cargos, Carreiras e Remuneração (PCCR) e do Plano de Funções em Comissão (PFC) tornam a dimensão Sistema de Recompensa bastante flexível, a ponto de apoiar a criação de novos processos e possibilitar a atração e retenção de competências necessárias a estes novos processos. No caso da Organização $A$, que atua em um setor de alta tecnologia e inovação, é muito provável que seja necessário criar novos processos, principalmente processos de negócio. 


\section{Interação Sistemas de Recompensa - Estrutura:}

Da mesma forma que a interação Sistema de Recompensa - Processos analisada anteriormente, na interação com a dimensão Estrutura, também, a flexibilidade do PPCR e do PFC suportam a criação de novas áreas, com a contratação ou realocação de novos talentos, de forma a comportar atividades inovadoras que sejam necessárias.

\section{Interação Processos - Estrutura:}

Analisando a interação da dimensão Processos com a dimensão Estrutura, percebe-se que há significativa congruência (match) entre os processos da estrutura de macroprocessos e as áreas existentes na Organização A. Uma observação a ser feita, no entanto, está relacionada aos processos de Serviços Gerais, que na época do estudo encontravam-se distribuídos em diferentes áreas. Seria interessante que a Organização A criasse uma área específica, que passaria a ser a gestora destes serviços.

Outra observação a ser mencionada diz respeito aos macroprocessos Pesquisa e aos macroprocessos de Fomento (Formação de Recursos Humanos, Formação de Alianças Estratégicas e Formação de Arranjo Produtivo Regional), que na época deste estudo também não apresentavam áreas específicas para sua execução e gestão (nem colaboradores de outras áreas com esta responsabilidade). É certo que a execução de um processo não demanda necessariamente a criação de uma área na estrutura, porém é preciso que pelo menos haja um gestor responsável, mesmo que este atue em outras áreas da organização. 


\subsection{Subsistemas Produtivos da Organização A}

Considerando o conceito de subsistemas de um sistema produtivo abordado por Muscat (1993) e por Almeida (1981), um aspecto que deve ser observado na Organização A diz respeito à coexistência de diversos subsistemas produtivos dentro de uma mesma empresa. Podem-se identificar, por exemplo, um subsistema produtivo administrativo, um subsistema produtivo de projetos, outro subsistema voltado para a fabricação, etc., conforme esquematizado na Figura 5.1:

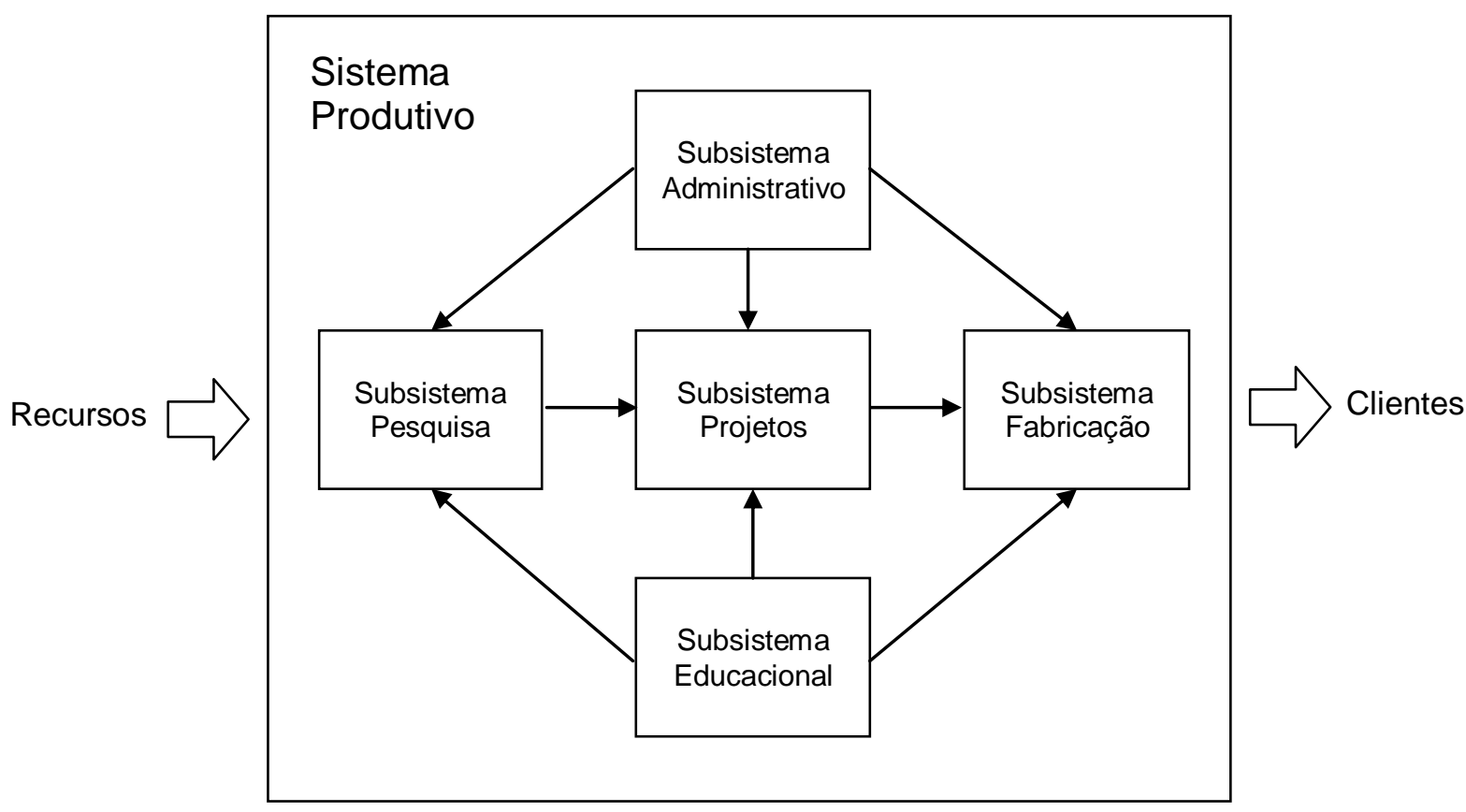

Figura 5.1 - Subsistemas de um Sistema Produtivo (Elaborada pela autora)

No exemplo hipotético esquematizado na Figura 5.1, observa-se que um Sistema Produtivo pode ser composto por vários subsistemas produtivos diferentes, como os subsistemas de Pesquisa, de Projetos, de Fabricação, Administrativo e Educacional. Cada subsistema utiliza recursos, que podem ou não ser oriundos de outros subsistemas da mesma organização, e cada subsistema gera produtos (bens ou serviços), que podem ser entregues ao cliente final, ou podem servir de recurso para outros subsistemas dentro da organização.

Da interação entre os diversos subistemas produtivos resulta o desempenho final da organização, transformando recursos nos vários produtos e serviços que ela 
irá entregar aos seus clientes. Deve-se notar que cada subsistema produtivo tem seu desenho próprio, composto pelas cinco dimensões - Estratégia, Pessoas, Sistemas de Recompensa, Processos e Estrutura -, sendo que todas as dimensões devem estar alinhadas entre si dentro de um subsistema, bem como todos os subsistemas devem estar alinhados entre si para que a organização atinja seus objetivos. A Figura 5.1, portanto, pode ser esquematizada considerando o desenho organizacional de cada subsistema, conforme a Figura 5.2: 


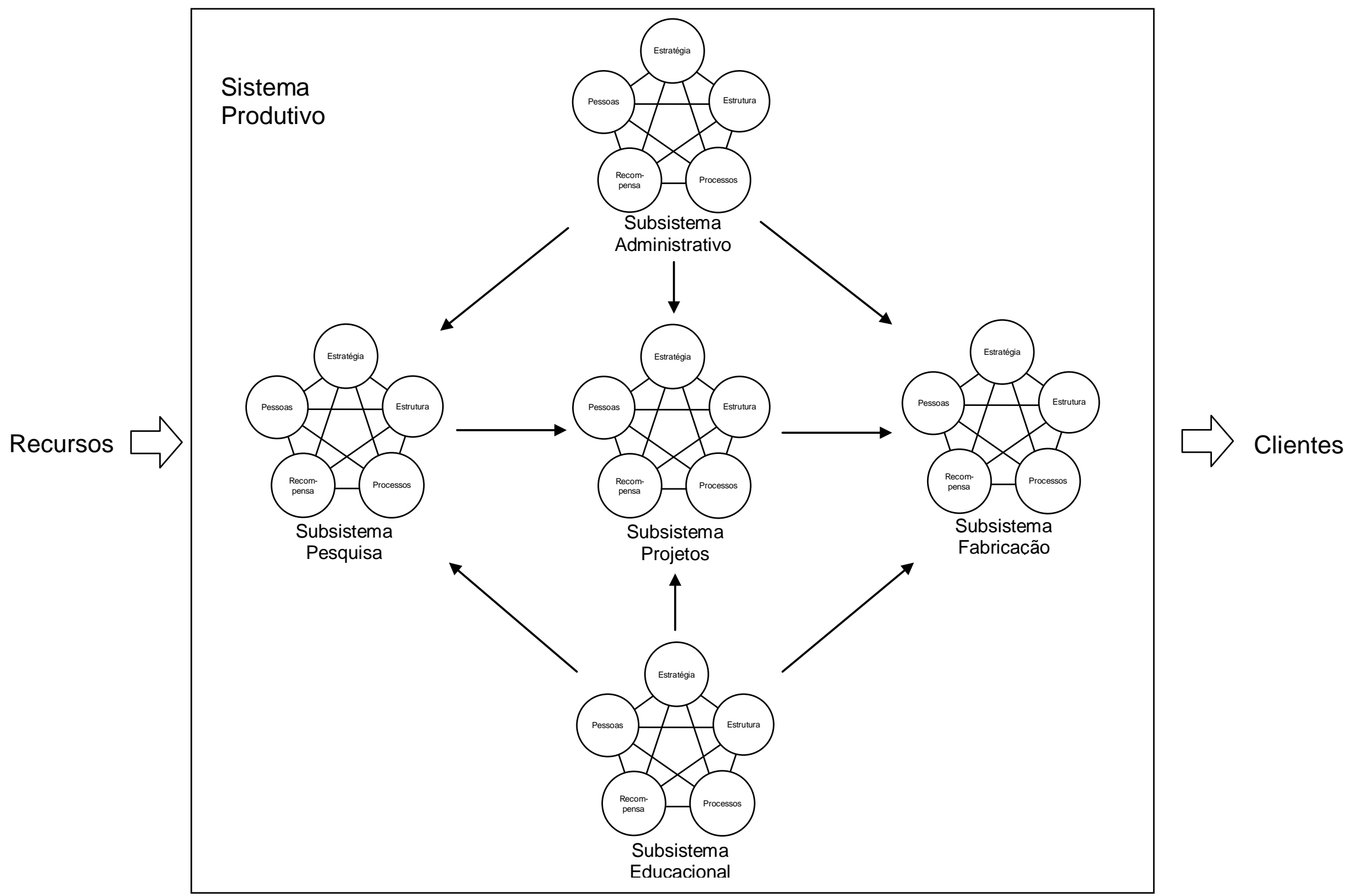

Figura 5.2 - Desenho Organizacional dos Subsistemas de um Sistema Produtivo (Elaborada pela autora) 
Para cada subsistema produtivo, pode-se optar por dimensões do desenho organizacional diferenciadas, ou seja, pode-se organizar cada subsistema produtivo de modo independente.

\section{Evolução do Desenho Organizacional no tempo}

Outro aspecto a ser analisado está relacionado à evolução do sistema produtivo que pode ocorrer ao longo do tempo, incluindo o aparecimento (ou a subtração) de diferentes subsistemas produtivos, de acordo com os objetivos de desempenho que a organização pretende atingir em cada momento de sua existência. À medida que o(s) objetivo(s) de desempenho muda(m), o conjunto de subsistemas produtivos muda, assim como o desenho organizacional de cada subsistema produtivo.

Analisando o caso da Organização A, pode-se observar uma evolução de seu sistema produtivo, conforme o Quadro 5.3, a seguir:

Quadro 5.3 - Evolução do Sistema Produtivo da Organização A

\begin{tabular}{|c|l|l|}
\hline Fases & \multicolumn{1}{|c|}{ Subsistemas Produtivos } & \multicolumn{1}{|c|}{ Objetivo de Desempenho } \\
\hline 1 & Administrativo & Estruturação da empresa \\
\hline 2 & Administrativo + Projeto & $\begin{array}{l}\text { Estruturação da empresa + } \\
\text { Margem de lucro }\end{array}$ \\
\hline 3 & Administrativo + Projeto + Produção & Margem de lucro \\
\hline 4 & $\begin{array}{l}\text { Administrativo + Projeto + Produção + } \\
\text { Pesquisa }\end{array}$ & $\begin{array}{l}\text { Margem de lucro + difusão } \\
\text { tecnológica }\end{array}$ \\
\hline 5 & $\begin{array}{l}\text { Administrativo + Projeto + Produção + } \\
\text { Pesquisa + Educacional }\end{array}$ & $\begin{array}{l}\text { Margem de lucro + difusão } \\
\text { tecnológica + Formação de APR }\end{array}$ \\
\hline
\end{tabular}

Fonte: Elaborado pela autora 
O caso da Organização A pode ser considerado peculiar, uma vez que a empresa foi criada pelo governo, por lei. Logo após sua criação, foi contratado pessoal administrativo temporário, passando a existir, inicialmente, apenas o subsistema produtivo "Administrativo", na Fase 1 da evolução do Sistema Produtivo. Nesta fase inicial, o objetivo de desempenho a ser atingido pela Organização A consistia em estruturar a empresa, mesmo que com recursos financeiros subsidiados pelo governo. A Figura 5.3 esquematiza o subsistema Administrativo existente na Fase 1; os demais subsistemas, representados com linha tracejada, ainda não se formaram nesta fase:

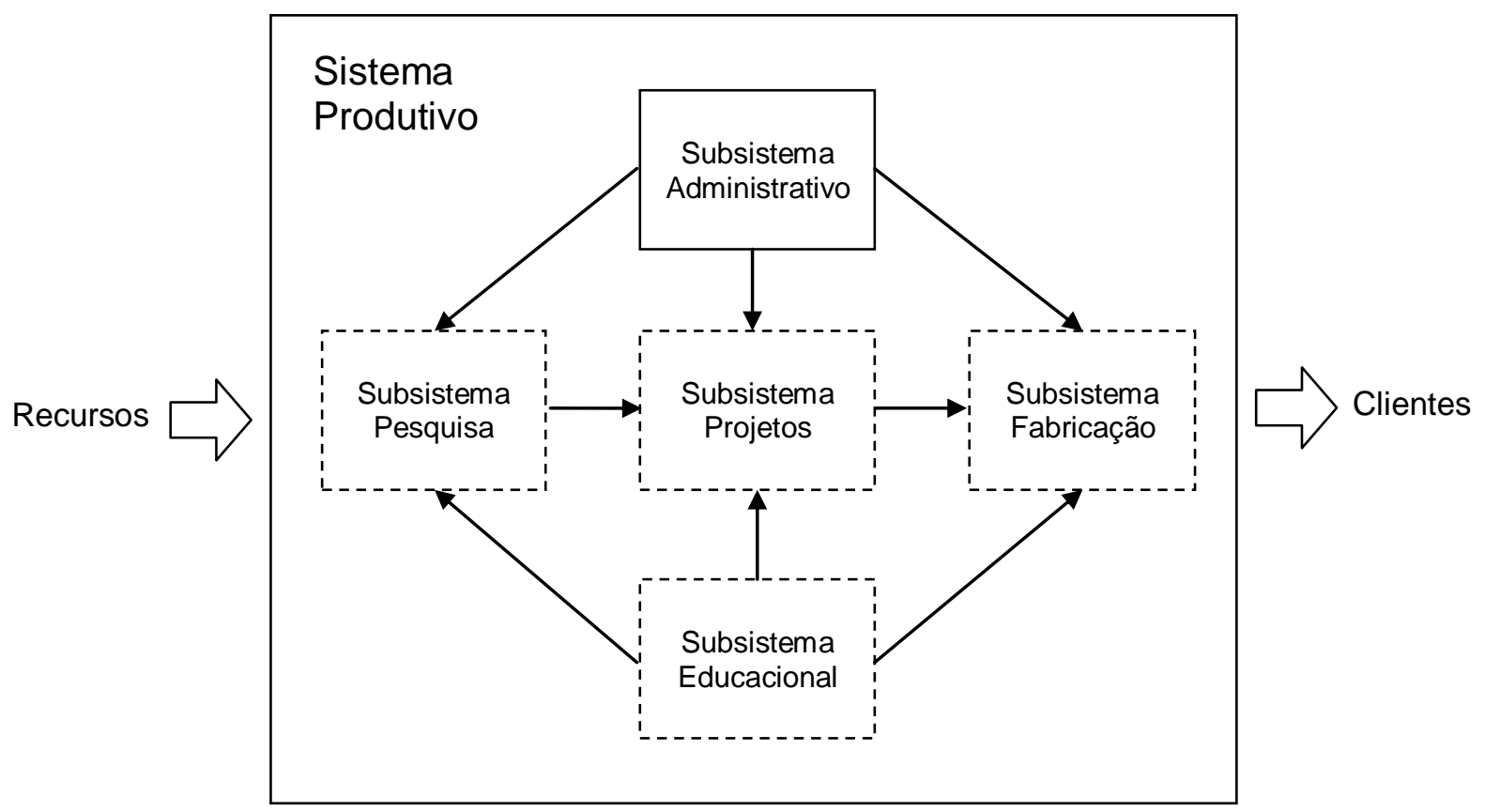

Figura 5.3 - Subsistemas da Organização A - Fase 1 (Elaborado pela autora)

A seguir, foi criada a área de Design da Organização A, que pode ser considerada como um subsistema produtivo de "Projeto", passando a existir simultaneamente com o subsistema produtivo "Administrativo", na Fase 2 da evolução. Nesta fase, a estruturação da empresa ainda era um objetivo a ser perseguido, porém já passa a existir a busca pela autossustentação por meio de lucro, obtido pela venda dos produtos de Design, denominados "amostras de engenharia", em outras palavras, designs de chip, que poderiam ser fabricados fisicamente por outras empresas já estabelecidas. A Figura 5.4 esquematiza os subsistemas existentes na Fase 2: 


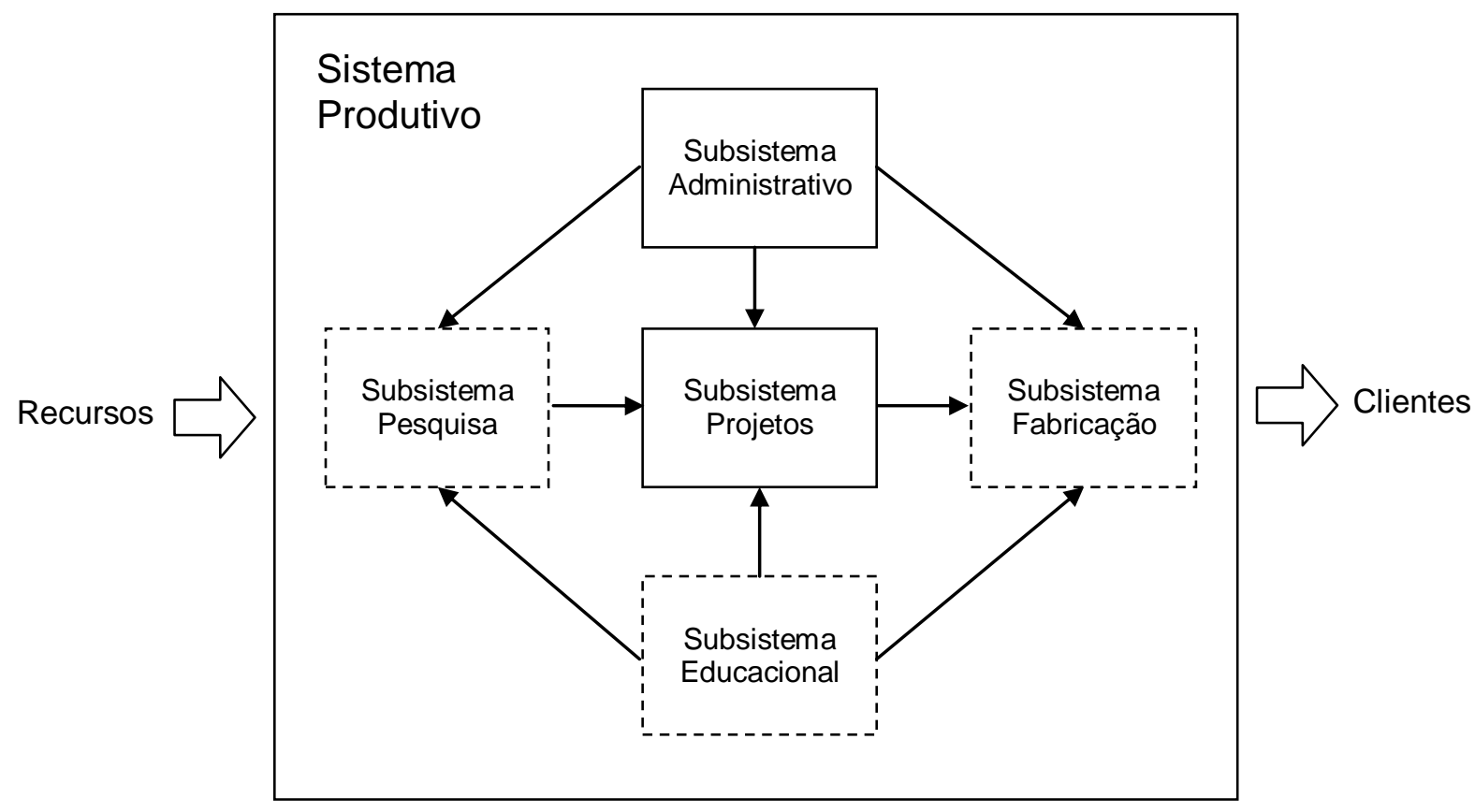

Figura 5.4 - Subsistemas da Organização A - Fase 2 (Elaborada pela autora)

$\mathrm{Na}$ época em que foi realizada a presente pesquisa, a Organização encontrava-se na etapa de conclusão das instalações de sua fábrica de chips e certificação dos equipamentos instalados. Percebe-se, portanto, que a empresa estava passando da Fase 2 para a Fase 3 da evolução de seus subsistemas produtivos. Na Fase 3, passam a coexistir, portanto, os subsistemas produtivos "Administrativo", de "Projeto" (Design) e de "Produção" (Fábrica). As interações das dimensões do desenho organizacional e entre estas e o ambiente, sintetizadas anteriormente no Quadro 5.2, referem-se especificamente a esta fase de existência da empresa.

Nesta Fase 3, a empresa passa a buscar principalmente o lucro como objetivo de desempenho, visando tornar-se autossuficiente em relação ao subsídio financeiro do governo, conforme foi realmente observado durante o estudo de caso realizado. A Figura 5.5 esquematiza os subsistemas existentes na Fase 3 : 


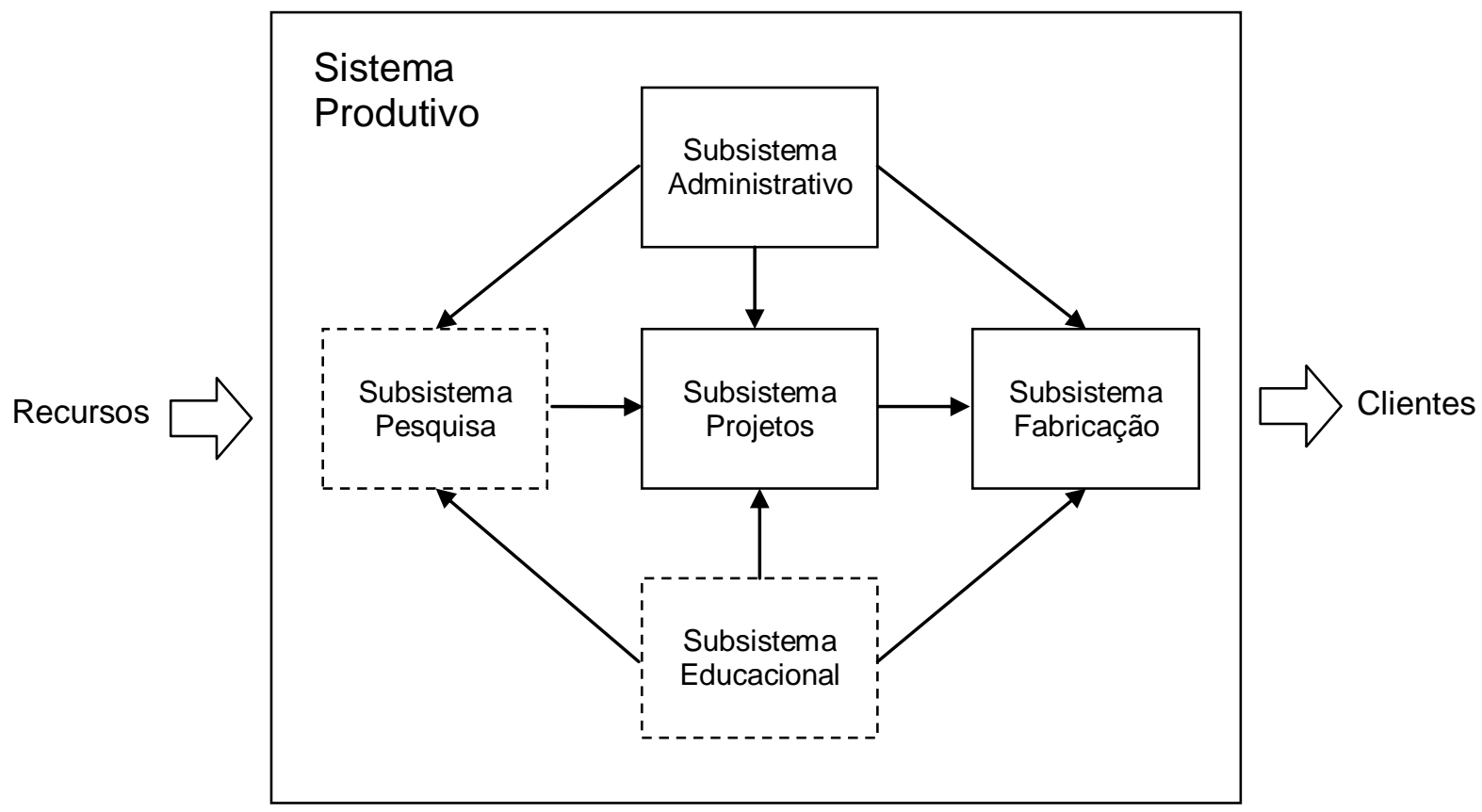

Figura 5.5 - Subsistemas da Organização A - Fase 3 (Elaborada pela autora)

Para dar continuidade aos objetivos descritos em sua lei de criação, a Organização A, em algum momento (Fase 4 ou 5), teria de criar o subsistema produtivo de "Pesquisa", visando aprofundar, aplicar e divulgar os conhecimentos tecnológicos entre as empresas do setor de semicondutores e de microeletrônica. Em seguida, deveria ser estruturado o subsistema "Educacional" (Fase 4 ou 5), com objetivo de difundir os conhecimentos entre as empresas do setor de semicondutores e de microeletrônica e formar mão de obra altamente qualificada, propiciando a formação de um arranjo produtivo regional (APR). É importante notar que não existe necessariamente uma ordem de formação dos subsistemas "Pesquisa" e "Educacional", sendo que ambos poderiam ser estruturados simultaneamente. Na época de realização da presente pesquisa, no entanto, estes subsistemas ainda não existiam de maneira formalizada. 


\section{SÍNTESE DO CASO}

Este trabalho tem como objeto de estudo a criação de uma empresa pública do setor de semicondutores, com foco em seu desenho organizacional. A criação de uma empresa de semicondutores no Brasil, com forte apoio governamental, mostrase bastante positiva para o desenvolvimento do setor no país. Conforme as recomendações dos estudos de Amato et al (2002), havia fortes aspectos motivadores para se desenvolver a indústria de semicondutores no Brasil, sendo que alguns nichos de mercado e partes do processo poderiam ser viáveis para se iniciar o desenvolvimento dessa indústria.

A etapa de Projeto (Design) do processo produtivo apresentava oportunidades, podendo-se citar:

- Investimentos menores, tomando como exemplo o sucesso das empresas dedicadas de Taiwan;

- Existência de universidades e grupos de pesquisa bastante ativos em desenvolvimento de softwares e em microeletrônica;

- Crescente importância dos softwares na cadeia de desenvolvimento de componentes eletrônicos no Brasil;

- Infraestrutura de comunicação com a rede mundial de computadores similar à do primeiro mundo.

Analisando a implantação da Organização A, percebe-se que o primeiro subsistema produtivo instalado foi justamente o de Design (logo após o subsistema administrativo), uma vez que este requer um investimento menor, apesar de enfrentar o desafio de obter mão de obra altamente qualificada.

Com relação ao investimento na etapa de fabricação, havia oportunidades para investimentos em fábricas que não necessitassem tecnologia de ponta, visando a entrada em nichos de mercado, com menor demanda de investimento de capital, podendo utilizar equipamentos relativamente baratos de fábricas que estavam sendo desativadas, conforme apresentado por Amato et al (2002). Exatamente como recomendado, a Organização $A$ buscou montar sua fábrica utilizando equipamentos 
de tecnologia já dominada pelo mercado (obteve doação de equipamentos de fábrica desativada), visando produzir chips para nichos de mercado específicos (RFID e wireless).

Havia oportunidades, também, para iniciar o desenvolvimento do setor pelas atividades de back-end, ou seja, pelo empacotamento e testes, uma vez que exigem um investimento relativamente menor.

Nos três casos, o apoio governamental é citado como essencial, visando criar condições para atrair investidores. Analisando a história do setor de semicondutores, Mowery e Nelson (1999) observaram que o envolvimento do governo teve papel fundamental na evolução deste setor em países como Estados Unidos, Japão e Coreia do Sul. A análise da evolução do setor de semicondutores tem sido o foco de atenção de vários pesquisadores (DIBIAGGIO, 2007; KAPOOR e ADNER, 2007; CLENDENIN, 2007; MALERBA et al, 2008b; LI, HUANG e CHEN, 2010), que também citam a importância das políticas governamentais. O comprometimento de longo prazo do governo, portanto, pode ser considerado determinante para 0 desenvolvimento desta indústria, por meio de subsídios, investimentos de capital, isenção de impostos ou apoio à criação de centros de pesquisa, entre outros, conforme se observa em vários países, tais como EUA, Japão, Coreia, Alemanha, Taiwan e outros. A criação da Organização A, neste aspecto, mostra o comprometimento do governo brasileiro para com o desenvolvimento do setor no país.

Outros aspectos também são considerados determinantes para o desenvolvimento do setor de semicondutores (AMATO et al, 2002):

- Disponibilidade de mão de obra especializada - a capacitação da mão de obra brasileira poderia ser alavancada através de incentivos para a migração de recursos humanos externos. Para se formar um engenheiro desde o início, leva-se muito tempo, mas com migração de recursos, esse tempo diminui consideravelmente;

- Infraestrutura para logística, incluindo aeroportos, estradas, energia e comunicação;

- Regime aduaneiro rápido. 
Com relação a estes aspectos citados acima, devem-se comentar algumas dificuldades percebidas durante o estudo de caso. Com relação à mão de obra, observou-se durante o estudo de caso uma clara tentativa de facilitar a obtenção de mão de obra especializada em alta tecnologia ao se definir a localização da empresa nas proximidades de um grande centro universitário. A mão de obra em uma fábrica de semicondutores deve ser altamente qualificada. São profissionais que precisam ser os melhores em suas áreas, abrangendo desde físicos e matemáticos até biólogos. Do ponto de vista da empresa, a existência nas proximidades de grupos de pesquisa sem dúvida facilitaria a obtenção de mão de obra a ser contratada. Indo além, do ponto de vista dos universitários, a própria existência da empresa como possível local para o desenvolvimento de estágios de iniciação científica, de projetos de mestrado e de doutorado consistia em mais um incentivo para chamar uma quantidade cada vez maior de interessados em seguir carreira nessa área. A dificuldade fica evidente, no entanto, ao se observar que as necessidades da Organização A eram bastante específicas, sendo preciso obter pessoal experiente, e não apenas mão de obra em formação. Para tanto, conforme observado, foi necessário buscar talentos no exterior, de forma a viabilizar a instalação da operação, além de compartilhar e disseminar os conhecimentos necessários para os demais colaboradores da empresa. A contratação de mão de obra externa pode ser encarada como uma dificuldade, uma vez que é necessário criar as condições para atrair e manter talentos no Brasil, considerando inclusive a realidade de empresa do setor público. Além disso, considerando que o setor de semicondutores é extremamente dinâmico, apresentando alta velocidade evolutiva, a necessidade de formar e desenvolver mão de obra, o que leva anos, consiste em mais uma dificuldade.

Com relação à infraestrutura logística, incluindo aeroportos, estradas, energia e comunicação, percebe-se que o país ainda não oferece os atributos necessários para empresas do setor de semicondutores. Por ser de alta tecnologia, o mercado de semicondutores demanda toda uma cadeia de suprimentos e logística que não existe no Brasil. Apesar dos avanços dos últimos anos, a infraestrutura ainda precisaria melhorar muito, além do custo da energia ser elevadíssimo (ISTO É DINHEIRO, 2012). O Brasil tem tentado há anos atrair empresas de microeletrônica, incluindo a de semicondutores, porém a falta de infraestrutura é apontada como um 
dos principais limitadores para estes investimentos (TECNOLOGIA TERRA, 2011). Fabricar um semicondutor exige três grandes passos. O primeiro é obter e dar forma ao silício cristalino, principal matéria prima dos chips. O segundo é, em cima do silício, construir os processadores. Esta é a etapa mais importante e complexa. Por último, é executada a etapa de encapsulamento e conexões elétricas. O processo é extremamente complicado por conta da miniaturização dos componentes necessários, ou seja, qualquer grão de areia ganha dimensões enormes, atrapalhando o processo. Por esse motivo, uma fábrica de chips precisa de um ambiente especial, a chamada "sala limpa". Em alguns casos, o processo de corte do silício é feito dentro d'água, que, necessariamente, precisa ser extremamente limpa. Além deste ambiente, a fábrica precisa produzir em larga escala, porque os investimentos necessários são altíssimos (COMPUTERWORLD, 2008).

Outra dificuldade a ser vencida no Brasil diz respeito à legislação tributária brasileira, que é muito complexa, além de o desembaraço aduaneiro ser diferente do de países desenvolvidos (ISTO É DINHEIRO, 2012). A questão tributária é o menor obstáculo. Apesar do ICMS ainda ser muito caro sobre o investimento, os estados podem conceder incentivos que equiparam as condições brasileiras com as de outros países (COMPUTERWORLD, 2008). A questão aduaneira, no entanto, é mais complexa. A demora em conseguir matéria prima e materiais necessários é apontada como outro fator limitador para o desenvolvimento do setor de semicondutores no país. Em países desenvolvidos, se falta um determinado material, os pesquisadores conseguem recebê-lo no dia seguinte. No Brasil, há trâmites legais de importação, o que significa que mesmo quando há verba disponível para a compra do material, é preciso esperar de dois a três meses até recebê-lo (TECNOLOGIA TERRA, 2011). Além disso, no caso específico da Organização $A$, pelo fato de ser empresa do setor público, há necessidade de cumprir os processos de aquisição definidos pela Lei 8.666 de 21/06/93, aumentando a demora no atendimento da necessidade. Considerando que a grande maioria dos fornecedores de matérias primas e materiais utilizados pela Organização A são externos, os processos de aquisição acabam sendo muito lentos. Para ter mais chances de sucesso em um setor dinâmico como o de semicondutores, deveria haver um "match" entre a velocidade das decisões em uma empresa pública e a alta velocidade evolutiva do setor. 
Um aspecto que deve ser mencionado, considerando que a organização em estudo é uma empresa pública, é a questão dos interesses políticos existentes no ambiente do setor público, o que influencia fortemente aspectos de seu desenho organizacional, conforme citado por McAdam e Donaghy (1999). Com relação à dimensão estratégia, é possível que a empresa tenha que analisar, além das oportunidades e ameaças do mercado e de seus pontos fortes e fracos, aspectos relacionados aos interesses políticos do período, que nem sempre apontarão para o mesmo caminho a seguir. Do ponto de vista da dimensão estrutura, por sua vez, os interesses políticos exercem fortíssima influência, uma vez que os cargos mais altos dentro da empresa são ocupados por nomeação, podendo ser modificados a qualquer momento. Este fato acaba amarrando fortemente não somente a estrutura organizacional, mas a própria configuração de poder dentro da empresa. Conforme citado por Gonçalves, Pinto e Barreto (1987), o processo de construção da decisão na administração pública muitas vezes sofre influências de "anéis" de interesses específicos e transitórios, formados por grupos que circundam a pessoa que ocupa um cargo de poder público, conceito lançado por Cardoso (1975). Mesmo na dimensão processos, observou-se durante o estudo de caso a importância do relacionamento político para a adequação dos processos internos. No caso do processo de Compras, por exemplo, foi necessário adequar a legislação vigente para possibilitar a importação de matérias primas necessárias, o que demandou articulações políticas junto ao Congresso Nacional. A própria seleção do local de construção da empresa, com certeza apresentou forte influência de interesses políticos, uma vez que envolve negociações de isenção fiscal e a possibilidade de desenvolvimento regional, entre outros.

A análise do desenho organizacional da Organização $A$, descrita neste trabalho, considerou as várias dimensões inicialmente de forma desagregada. Um resumo dos resultados obtidos nesta etapa da análise foi apresentado no Quadro 5.1. A seguir, foram analisadas as interações entre as dimensões e entre estas e o ambiente da Organização A. Os resultados desta segunda etapa da análise foram apresentados de forma resumida no Quadro 5.2. Por fim, foi feita uma análise dos diversos subsistemas produtivos existentes na Organização A, assim como sua evolução ao longo do tempo, apresentada no Quadro 5.3. 


\section{CONCLUSÃO}

Este trabalho teve como objeto de estudo uma empresa brasileira de semicondutores do setor público, com foco em seu desenho organizacional. A iniciativa de criar uma empresa de semicondutores no Brasil, com forte apoio governamental, mostrou-se bastante positiva para o desenvolvimento do setor no país. O governo agiu bem ao investir na empresa, que passa a fazer parte de um esforço para criar um ambiente favorável ao desenvolvimento do setor de semicondutores no Brasil. Por mais que a empresa em estudo ainda esteja longe dos grandes players do setor, a Organização $A$ pode ser considerada uma iniciativa importante para a inclusão do Brasil no mapa da alta tecnologia. Conforme discutido nesta pesquisa, há fortes aspectos motivadores para se desenvolver a indústria de semicondutores no Brasil, sendo que alguns nichos de mercado e partes do processo produtivo poderiam ser viáveis para se iniciar o desenvolvimento dessa indústria. Com a Organização A, espera-se que, aos poucos, o Brasil passe a ter toda uma indústria desenvolvida em torno da empresa pública criada. Dessa forma, o país passaria a atrair grandes fabricantes e, daqui a alguns anos, ter condições de se candidatar a entrar de fato no mercado.

A principal contribuição deste trabalho consistiu na análise do desenho organizacional adotado pela empresa em estudo, visando considerar a organização de uma maneira integrada e sistêmica, englobando todas as cinco dimensões do desenho organizacional, a saber, Estratégia, Pessoas, Sistemas de Recompensa, Processos e Estrutura, além de identificar as interações entre as diversas dimensões e entre estas e o ambiente de atuação da empresa. Outra contribuição do presente trabalho está relacionada à análise da evolução dos subsistemas produtivos na organização ao longo do tempo, assim como a evolução dos objetivos de desempenho a serem buscados pela organização. Estas contribuições serão detalhadas ao serem retomadas as questões de pesquisa, no item a seguir.

Pode-se notar que as contribuições resultantes deste trabalho podem se aplicar tanto à prática, quanto à teoria. Os resultados da descrição do caso, da análise do desenho organizacional e seu ambiente, de suas dimensões e interações, constituem contribuição para a prática, uma vez que, sendo específicos da 
Organização A, contribuem para a própria direção da Organização A, fornecendo um enfoque integrado e sistêmico de vários aspectos da empresa. Por outro lado, a metodologia de análise utilizada neste trabalho, considerando não apenas as interações entre as dimensões do desenho organizacional e seu ambiente, mas também seus equilíbrios dinâmicos e a consequente evolução dos sistemas e subsistemas produtivos ao longo do tempo, consiste em contribuição para a própria teoria das organizações.

Ao longo do estudo de caso, foram observados também alguns obstáculos que acabam refletindo no próprio desenvolvimento do setor de semicondutores, conforme foi discutido em detalhe anteriormente. Entre eles, pode-se citar a falta de mão de obra especializada, havendo necessidade de, em um primeiro momento, criar condições e atrair talentos externos para auxiliar na formação de mão de obra nacional. Outra questão apontada como limitadora consiste na falta de infraestrutura para o desenvolvimento do setor, incluindo aspectos de logística, aeroportos, estradas, energia e comunicação. Os aspectos tributários existentes no Brasil também foram apontados como um obstáculo para o desenvolvimento do setor, embora possam ser minimizados com incentivos fiscais. A questão aduaneira, no entanto, mostra-se mais complexa. Os trâmites legais de importação são muito lentos, dificultando o processo de aquisição de matérias primas, principalmente em uma empresa pública. Há necessidade de haver um "match" entre a velocidade das decisões em uma empresa pública e a alta velocidade evolutiva do setor de semicondutores.

Um aspecto que foi mencionado, considerando que a organização em estudo é uma empresa pública, é a questão dos interesses políticos existentes no ambiente do setor público brasileiro, o que influencia fortemente vários aspectos de seu desenho organizacional, como a estratégia a ser a adotada, a estrutura organizacional e a configuração de poder dentro da empresa, os processos internos, além da própria seleção da localização da empresa.

Para finalizar o presente trabalho, pretende-se, neste capítulo, rever e analisar as questões de pesquisa que se pretendia responder. Por fim, serão avaliadas as limitações da pesquisa e possíveis extensões dos resultados obtidos com o trabalho. 


\subsection{Questões da Pesquisa}

As questões que se buscou responder neste trabalho foram as seguintes: "Como deve ser o desenho organizacional adotado por uma empresa pública brasileira do setor de semicondutores?" e "Como interagem as diversas dimensões do desenho organizacional de uma empresa pública brasileira do setor de semicondutores entre si e com o ambiente?" Para responder a estas questões, foi realizado um estudo de caso em uma empresa pública brasileira do setor de semicondutores, um empreendimento único no Brasil, sendo possível avaliar as diferentes dimensões de seu desenho organizacional (Estratégia, Pessoas, Sistemas de Recompensa, Processos e Estrutura), além de suas interdependências e equilíbrios dinâmicos, considerando a realidade de empresa pública brasileira.

Com base no estudo de caso, foi possível analisar aspectos relevantes de cada dimensão do desenho organizacional da empresa estudada:

- Estratégia - ao analisar a dimensão Estratégia do desenho organizacional, observou-se que a Organização A não apresentava inicialmente sua estratégia de atuação definida e nem seu planejamento estratégico elaborado. A empresa demandava, portanto, com urgência, a elaboração de seu planejamento estratégico, de forma a definir suas metas e objetivos a serem alcançados, norteando as atividades da organização;

- Pessoas - a dimensão Pessoas apresentava urgência com relação à definição da situação dos colaboradores, que trabalhavam com base em contrato temporário, o que gerava significativa instabilidade no quadro de pessoal. As ações desenvolvidas durante a reestruturação dimensionamento de pessoal, definição de cargos necessários e respectivas atribuições, encaminhamento do Concurso Público e elaboração do Regulamento de Pessoal - apresentaram resultados altamente positivos, uma vez que foram encaminhadas questões urgentes para a gestão de pessoas da empresa;

- Sistemas de Recompensa - durante a reestruturação da Organização A, foram desenvolvidas quatro ações: definição do Plano de Cargos, Carreiras e 
Remuneração (PCCR), definição do Plano de Funções em Comissão (PFC), elaboração do Regulamento de Progressão e Promoção e elaboração do Regulamento de Remuneração Variável e Gratificação de Desempenho. Observou-se que estas ações apresentaram resultados altamente positivos com relação à dimensão Sistemas de Recompensa, uma vez que foram encaminhadas questões urgentes para a gestão de pessoas da empresa;

- Processos - com relação à dimensão Processos, antes da reestruturação, a Organização A apresentava alguns poucos procedimentos descritos, relacionados a demandas pontuais. Durante a reestruturação da empresa, foi identificada a lista de macroprocessos, processos e subprocessos, sendo construída a matriz de macroprocessos da empresa, incluindo macroprocessos previstos na missão da empresa, mas que ainda não estavam sendo executados. Após a priorização dos processos, aqueles considerados mais críticos foram mapeados e tiveram seus procedimentos descritos, o que pode ser considerado como um resultado positivo da reestruturação. Deve-se notar, no entanto, que o levantamento da lista de processos e a elaboração de alguns procedimentos mais críticos realizados durante a reestruturação constituiu apenas um esforço inicial para reorganizar e definir a dimensão processos. Seria recomendável que a Organização A despendesse mais tempo para mapear de forma detalhada seus processos, integrando as atividades das diversas áreas, em uma visão matricial. Esta integração entre as áreas não chegou a ser executada durante a reestruturação, uma vez que o levantamento focou principalmente na sequência de atividades dentro de cada área, para a elaboração de procedimentos operacionais;

- Estrutura Organizacional - analisando a dimensão Estrutura Organizacional, antes do projeto de reestruturação, a Organização A já possuía um organograma definido, conforme apresentado na descrição do caso. Ao longo da reestruturação, entretanto, foram propostas alterações, no sentido de adequar a estrutura aos processos que deveriam ser executados para se atingir os objetivos estratégicos da empresa. 
Uma vez analisados os aspectos de cada dimensão do desenho organizacional, foi possível analisar as interações entre cada dimensão e entre estas e o ambiente da organização em estudo (apresentadas no Quadro 5.2), considerando inclusive o fato da organização em estudo ser uma empresa do setor público. Indo além, foi possível identificar os vários subsistemas produtivos presentes na empresa, bem como prever uma possível evolução destes subsistemas ao longo do tempo.

Segundo o modelo de desenho organizacional proposto por Galbraith, (GALBRAITH, 2009), esquematizado na Figura 2.3, uma organização deve fazer opções nas dimensões de seu desenho organizacional para atingir seus objetivos, ou seja, deve definir as dimensões Estratégia, Pessoas, Sistemas de Recompensa, Processos e Estrutura, visando obter alinhamento entre estas dimensões. Estas diferentes dimensões são interdependentes e interagem entre si; ao se alterar uma determinada dimensão, as demais dimensões sentirão o impacto desta alteração, sendo possivelmente alteradas também. Ampliando o modelo proposto por Galbraith, é importante notar que as interações do desenho organizacional de uma empresa ocorrem não somente entre as dimensões internas da organização, mas também entre estas dimensões e o ambiente em que a organização atua, seja ele ambiente legal, físico, político, do mercado ou do setor de atuação da empresa. Mais do que isso, é necessário compreender que todas estas interações encontram-se em equilíbrio dinâmico entre si e com o ambiente, conforme foi proposto e esquematizado na Figura 2.11.

Ao se construir o desenho organizacional, é fundamental identificar e compreender os diversos aspectos (variáveis) que influenciam e alteram tais equilíbrios entre as dimensões, de forma que, ao longo da existência da organização, esta possa gerenciá-los para que se mantenha o alinhamento interno entre todas as dimensões e entre as dimensões e o ambiente. $O$ desenho organizacional deve considerar, inclusive, as características do setor de atuação da empresa, no caso uma empresa de semicondutores do setor público brasileiro. Além disso, deve considerar a missão da organização criada, incluindo os objetivos de fomentar o desenvolvimento do setor de microeletrônica no Brasil e a formação de recursos humanos específicos para este setor. A iniciativa do governo federal de 
criar uma empresa de semicondutores proporcionou uma oportunidade ímpar para se desenvolver tais pesquisas no setor público.

Os resultados da análise das interações entre as diversas dimensões do desenho organizacional da Organização A, e entre estas e o ambiente, é apresentado no Quadro 5.2.

Outro aspecto que foi analisado está relacionado à evolução do sistema produtivo da Organização A ao longo do tempo, incluindo o aparecimento (ou a subtração) de diferentes subsistemas produtivos, de acordo com os objetivos de desempenho que a organização pretende atingir em cada momento de sua existência. À medida que o(s) objetivo(s) de desempenho muda(m), o conjunto de subsistemas produtivos muda, assim como o desenho organizacional de cada subsistema produtivo. Os resultados desta análise são apresentados no Quadro 5.3, sendo que foram identificadas cinco fases, englobando os seguintes subsistemas produtivos e objetivos de desempenho:

1. Administrativo - Esta fase apresenta o objetivo de desempenho estruturação da empresa;

2. Administrativo + Projeto - Esta fase apresenta os objetivos de desempenho estruturação da empresa e margem de lucro;

3. Administrativo + Projeto + Produção - Apresenta o objetivo de desempenho margem de lucro;

4. Administrativo + Projeto + Produção + Pesquisa - Apresenta os objetivos de desempenho margem de lucro e difusão tecnológica;

5. Administrativo + Projeto + Produção + Pesquisa + Educacional - Apresenta os objetivos de desempenho margem de lucro, difusão tecnológica e formação de APR.

Deve-se notar que, na época em que foi realizada a presente pesquisa, a Organização A encontrava-se na etapa de conclusão das instalações de sua fábrica de chips e certificação dos equipamentos instalados, ou seja, a empresa estava passando da Fase 2 para a Fase 3 da evolução de seus subsistemas produtivos. Na 
Fase 3, passam a coexistir, portanto, os subsistemas produtivos "Administrativo", de "Projeto" (Design) e de "Produção" (Fábrica). As interações das dimensões do desenho organizacional e entre estas e o ambiente, sintetizadas anteriormente no Quadro 5.2, referem-se especificamente a esta fase de existência da empresa.

\subsection{Limitações da Pesquisa e Extensões dos Resultados Obtidos}

A participação direta da autora deste trabalho no caso estudado colaborou para a melhor compreensão e análise dos resultados, facilitando o alcance dos objetivos propostos. Pode-se considerar como limitação da pesquisa o fato do estudo de caso ter sido desenvolvido em apenas uma organização. Apesar deste aspecto, a realização do presente estudo de caso é válida, uma vez que a empresa em estudo pode ser considerada sui generis. Pode-se sugerir como extensão da pesquisa a aplicação da análise do desenho organizacional, de suas dimensões e interações, em outras empresas públicas brasileiras, ou mesmo em empresas do setor privado.

Por fim, a autora da presente pesquisa considera que ela pode ser enriquecida com o aprofundamento da análise das dimensões do desenho organizacional e de seus equilíbrios dinâmicos, considerando não apenas uma fase do sistema produtivo, mas também sua evolução ao longo do tempo. Além disso, a forma de análise utilizada, considerando os equilíbrios dinâmicos das interações entre as dimensões do desenho organizacional, e ainda a evolução deste último ao longo do tempo, pode ser considerada como um desdobramento deste trabalho para a teoria, consistindo em um adicional ao modelo da estrela proposto por Galbraith (2009). Seria interessante aprofundar o estudo dos mecanismos causadores de mudança no desenho organizacional, buscando administrar os vários equilíbrios e interações nele existentes, de modo a obter as modificações desejadas à medida que os objetivos de desempenho evoluem ao longo da vida de uma organização. 


\section{REFERÊNCIAS}

ABINEE, 2011. Releases ABINEE, 14/12/11, disponível em http://www.abinee.org.br/noticias/releases.htm , consultado em 25/01/12.

ABINEE, 2012, http://www.abinee.org.br/abinee/decon/decon11.htm, consultado em 03/06/12.

ACKOFF, R. L. Creating the Corporate Future. New York: John Wiley e Sons, 1981. $297 \mathrm{p}$.

ALDAMA, L. R. P.; AMAR, P. A.; TROSTIANKI, D. W. Embedding corporate responsibility through effective organizational structures. Corporate Governance, Vol. 9, No. 4, p. 506-516, 2009.

ALMEIDA, H. S. Um Estudo do Vínculo Tecnológico entre: Pesquisa, Engenharia, Fabricação e Consumo. 1981. 163 p. Tese (Doutorado) - Escola Politécnica, Universidade de São Paulo, São Paulo, 1981.

AMATO Neto, J.; CARVALHO, M. M.; LAURINDO, F. J. B.; GARCIA, R.; FLEURY, A. C. C. Análise das condições de desenvolvimento da indústria brasileira de semicondutores. São Paulo: Departamento de Engenharia de Produção da Escola Politécnica da Universidade de São Paulo, 2002. Disponível em: http://www.prd.usp.br/redecoop//artigo\%20final\%20bah\%20poli\%20jun\%202002r.p df.

APEXBRASIL, http://www.apexbrasil.com.br/portal/publicacao/engine.wsp?tmp.area=464\&tmp.te $\underline{x t o=104}$, consultado em 03/06/12.

BAHRY, C. P.; TOLFO, S. R. Mobilização de competências nas atividades profissionais dos egressos de um programa de formação e aperfeiçoamento. Revista de Administração Pública, Vol. 41, No. 1, p. 125-44, Jan./Fev. 2007.

BECKER, J. L.; LUNARDI, G. L.; MAÇADA, A. C. G. Análise de eficiência dos Bancos Brasileiros: um enfoque nos investimentos realizados em Tecnologia de Informação (TI). Revista Produção, Vol. 13, No. 2, p. 70-81, 2003. 
BELLOU, V. Matching individuals and organizations: evidence from the Greek public sector. Employee Relations, Vol. 31, No. 5, p. 455-470, 2009.

BERTALANFFY, L. Teoria geral dos sistemas: fundamentos, desenvolvimento e aplicações. Tradução de Francisco M. Guimarães. Petrópolis: Vozes, 2009. 360 p. Título original: General System Theory.

BERTERO, C. O. Cultura Organizacional e Instrumentalização do Poder, in Fleury, M. T. L.; Fischer, R. M. Cultura e poder nas organizações. $2^{\underline{a}}$ ed. São Paulo: Atlas, 2009. $170 \mathrm{p}$.

BEYER, J. M.; TRICE, H. M. How an organization's rites reveal its culture. Organizational Dynamics, Vol. 15, No. 4, p. 5-24, 1986.

BOARDMAN, J.; SAUSER, B. Systems thinking: coping with 21st century problems. Boca Raton: CRC Press, 2008. 217 p.

BRANDÃO, H. P. et al. Gestão de desempenho por competências: integrando a gestão por competências, o balanced scorecard e a avaliação 360 graus. Revista de Administração Pública, Vol. 42, No. 5, p. 875-898, 2008.

BRESSER-PEREIRA, L. C. Da administração pública burocrática à gerencial. Revista do Serviço Público, Vol. 120 No. 1, p. 7-40, 1996.

BROWN, K.; WATERHOUSE, J.; FLYNN, C. Change management practices - Is a hybrid model a better alternative for public sector agencies? The International Journal of Public Sector Management, Vol. 16 No. 3, p. 230-241, 2003.

CADERNOS GESPÚBLICA, No.1, 37 p. mar 2006.

CARBONE, P. P. Cultura organizacional do setor público brasileiro: desenvolvendo uma metodologia de gerenciamento da cultura. Revista de Administração Pública, Vol. 34 No. 2, p. 133-144, mar./abr. 2000.

CARDOSO, F. H. Autoritarismo e democratização. Rio de Janeiro: Paz e Terra, 1975. 240 p. 
CARMONA, S.; GRÖNLUND, A. Measures vs Actions: the balanced scorecard in Swedish Law Enforcement. International Journal of Operations \& Production Management, v. 23, n. 12, p. 1475-1496, 2003.

CARVALHO, M. M. et al. Gestão da Qualidade - Teoria e Casos. Rio de Janeiro: Elsevier, 2005. $355 \mathrm{p}$.

; LAURINDO, F. J. B. Estratégias para a competitividade. São Paulo: Futura, 2003. $254 \mathrm{p}$.

CARVALHO, P. Uma Perspectiva para a Indústria de Semicondutores no Brasil: o Desenvolvimento das "Design Houses". 2006. 155 p. Dissertação (Mestrado) - Instituto de Geociências, Unicamp, Campinas, 2006.

CGl.br, 2010 - http://g1.globo.com/tecnologia/noticia/2011/06/casas-brasileiras-comcomputador-aumentaram-9-em-2010-diz-estudo.html, consultado em 04/01/12.

CHANDLER, A. D. Strategy and Structure: Chapters in the History of the Industrial Enterprise. Cambridge: The MIT Press. 1962. 463 p.

CHECKLAND, P.; SHOLES, J. Soft Systems Methodology: a 30-year retrospective. Chichester: John Wiley e Sons, 1999. 329 p.

CHIAVENATO, I. Gestão de Pessoas. Rio de Janeiro: Campus. $3^{\text {a }}$ ed., 2008. 579 p.

. Introdução à Teoria Geral da Administração. Rio de Janeiro: Campus. $8^{\mathrm{a}}$ ed., $2011.640 \mathrm{p}$.

CHURCHMAN, C. W. El Enfoque de Sistemas. México: Editorial Diana, 1973. 270 p.

CLENDENIN, M. Will intel fab start an exodus? Electronic Engineering Times, $p$. 24-28, apr. 2007.

COMPUTERWORLD, 2008 - http://computerworld.uol.com.br/tecnologia/2008/09/04/ fabrica-de-semicondutores-no-brasil-possivel-mas-inviavel/, consultado em 27/05/12. 
CORRÊA, H. L.; CORRÊA, C. A. Administração de Produção e Operações: Manufatura e Serviços - Uma abordagem estratégica. São Paulo: Atlas, 2009. $2^{\mathrm{a}}$ ed. $690 \mathrm{p}$.

COSTA, I. S. A.; SALLES, D. M. R.; FONTES FILHO, J. R. Influência das configurações organizacionais sobre valores no trabalho e preferências por recompensa. Revista de Administração Pública, Vol. 44. No. 6, p. 1429-1452, 2010.

CTI, 2010, http://www.cti.gov.br/index.php/noticias/263-presidente-lula-inauguraprimeira-fabrica-de-chips-da-america-latina-.html, consultado em 03/06/12.

CUNHA, A. S. M. Uma experiência de reforma administrativa no nível municipal de governo: projeto piloto na prefeitura de Curitiba. Revista de Administração Pública, Vol. 36 No. 6, 981-1008, nov./dez. 2002.

DANSON, M. New regions and regionalization through clusters. International Journal of Public Sector Management, Vol. 22, No. 3, p. 260-271, 2009.

DAVENPORT, T. H. Process Innovation. Boston: Harvard Business School Press, 1993. $337 \mathrm{p}$.

DIBIAGGIO, L. Design complexity, vertical disintegration and knowledge organization in the semiconductor industry. Industrial and Corporate Change, Vol. 16, No 2, p. 239-267, 2007.

EISENHARDT, K. M. Building theories from case study research. The Academy of Management Review, Vol. 14 No. 4, p. 532-550, 1989.

EMERY, Y.; GIAUQUE, D. Emergence of contradictory injunctions in Swiss NPM projects. The International Journal of Public Sector Management, Vol. 16 No. 6, p. 468-481, 2003.

EMERY, E. F. Systems thinking. Harmondsworth: Penguin, 1969. 398 p.

FALLOWS, J. M. Looking at the Sun: the Rise of the New East Asian Economic and Political System. New York: Pantheon Books, 1994. 
FERGUSON, C. H. From the people who brought you woodoo economics. Harvard Business Review, Vol. 88, p. 55-62, 1988.

FISCHER, A. L. Um resgate conceitual e histórico dos modelos de gestão de pessoas, in Limongi-França et al, As Pessoas na Organização. São Paulo: Gente, 2002. 306 p.

FLEURY, M. T. L.; FISCHER, R. M. Cultura e poder nas organizações. $2^{\mathrm{a}}$ ed. São Paulo: Atlas, 2009. 170 p.

FLORIDA, R.; KENNEY, M. The Breakthrough Illusion. New York: Basic Books, 1990. $262 \mathrm{p}$.

FONTES FILHO, J. R.; PICOLIN, L. M. Governança corporativa em empresas estatais: avanços, propostas e limitações. Revista de Administração Pública, Vol. 42, No. 6, p. 1163-1188, 2008.

GALBRAITH, J. R. Organization Design. Reading: Addison-Wesley Publishing Company, 1977. $426 \mathrm{p}$.

. Competing with flexible lateral organizations. Reading: Addison-Wesley, 1994. $152 \mathrm{p}$.

Designing Matrix Organizations that actually work: how IBM, Procter \& Gamble, and others design for success. San Francisco: Jossey-Bass, 2009. $258 \mathrm{p}$.

GARCIA, A. E. B.; SALLES FILHO, S. L. M. Trajetória institucional de um instituto público de pesquisa: o caso do Ital após 1995. Revista de Administração Pública, Vol. 43, No. 3, p. 661-693, 2009.

GARVIN, D. A. General Management - Processes and Action. Boston: McGraw Hill, 2002. $630 \mathrm{p}$.

GAULD, R. The impact on officials of public sector restructuring - The case of the New Zealand health funding authority. The International Journal of Public Sector Management, Vol. 16 No. 4, p. 303-319, 2003. 
GHARAJEDAGHI, J. Systems thinking: managing chaos and complexity: a platform for designing business architecture. Amsterdam: Elsevier, 2006. 333 p.

GIDO, J.; CLEMENTS, J. P. Gestão de Projetos. Tradução de Vertice Translate. São Paulo: Thomson Learning, 2007. 451p. Título original: Successful Project Management.

GONÇALVES, M. A.; PINTO, M. C. C.; BARRETO, M. I. O processo de construção da decisão na Administração Pública. Cadernos FUNDAP, Ano 7, No. 14, p. 2732, out. 1987.

; MIYASHITA, H.; HERNANDEZ Fo, A.; BARROS, M. L. Vinte anos de consultoria organizacional na administração pública. Cadernos FUNDAP, No. 21, p. 126-136, set./dez. 1996.

GREASLEY, A. Process improvement within a HR division at a UK police force. International Journal of Operations \& Production Management, Vol. 24 No. 3, p. 230-240, 2004.

GROENEVELD, S. Diversity and employee turnover in the Dutch public sector. International Journal of Public Sector Management, Vol. 24, No. 6, 2011.

GRUENING, G. Origin and theoretical basis of New Public Management. International Public Management Journal, No. 4, p. 1-25, 2001.

GULLEDGE Jr., T. R.; SOMMER, R. A. Business process management: public sector implications. Business Process Management Journal, Vol. 8 No. 4, p. 364-376, 2002.

HAINES, S. G. The systems thinking approach to strategic planning and management. Boca Raton: St. Lucie Press, 2000. 361 p.

HAMMOND, D. The science of synthesis: exploring the social implications of general systems theory. Boulder: University Press of Colorado, 2003. 312 p.

HANNA, D. P. Designing Organizations for High Performance. Reading: AddisonWesley Publishing Company, 1988. 197 p. 
HARRINGTON, H. J. Business Process Improvement. New York: McGraw-Hill, 1991. $274 \mathrm{p}$.

HELLSTRÖM, A.; PETERSON, J. Adopting Process Management - the importance of recognizing the organizational transformation. The Asian Journal on Quality, Vol. 7, No. 1, p. 20-34, 2006.

HENDERSON, J. C.; VENKATRAMAN, N. Strategic alignment: leveraging information technology for transforming organizations. IBM Systems Journal, Vol. 32, No. 1, p. 4-16, 1993.

HERNANDEZ $F^{\circ}$, A.; FELICÍSSIMO, J. R. Mudança Organizacional na Administração Pública Brasileira. Cadernos FUNDAP, Ano 1, No. 2, p. 27-30, out. 1981.

HERRSCHEL, T. Regionalisation, "virtual" spaces and "real" territories. International Journal of Public Sector Management, Vol. 22, No. 3, p. 272-285, 2009.

HILL, T. The Essence of Operations Management. Hemel Hempstead: Prentice Hall, 1993. 143 p.

HIPÓLITO, J. A. M. Sistema de Recompensas: uma Abordagem Atual, in LimongiFrança et al, As Pessoas na Organização. São Paulo: Gente, 2002. 306 p.

HITCHINS, D. K. Advanced systems thinking, engineering, and management. Boston: Artech House, 2003. 469 p.

HOOD, C. A public management for all seasons? Public Administration, Vol. 69 No. 1, p. 3-19, 1991.

HOPE, K. R. The new public management: context and practice in Africa. International Public Management Journal, No. 4, p. 119-134, 2001.

HORTON, S. Participation and involvement - the democratisation of new public management? The International Journal of Public Sector Management, Vol. 16 No. 6, p. 403-411, 2003. 
ISTO É DINHEIRO, 09/03/2012 - Atualizado em 19/03/2012 http://www.istoedinheiro.com.br/noticias/79380 ILUSAO+DE+OTICA, consultado em 27/05/12.

JACKSON FILHO, J. M. Desenho do trabalho e patologia organizacional: um estudo de caso no serviço público. Revista Produção, Vol. 14, No. 3, p. 58-66, 2004.

JONES, L. R.; THOMPSON, F. Um modelo para a nova gerência pública. Revista do Serviço Público, Ano 51, No. 1, p. 41-78, jan-mar 2000.

JUNQUILHO, G. S. Nem "burocrata" nem "novo gerente": o "caboclo" e os desafios do Plano Diretor de Reforma do Estado no Brasil do real. Revista de Administração Pública, Vol. 38 No. 1, p. 137-156, jan./fev. 2004.

KAPLAN, R. S.; NORTON, D. P. The balanced scorecard - Measures that drive performance. Harvard Business Review, v. 70, n. 1, p. 71-79, 1992.

Using the balanced scorecard as a strategic management system.

Harvard Business Review, p. 75-85, jan./fev. 1996.

Having problem with your strategy? Then map it. Harvard Business Review, v. 78, n. 5, p. 167-176, set./out. 2000.

Balanced Scorecard - Mapas Estratégicos: convertendo ativos intangíveis em resultados tangíveis. Tradução de Afonso Celso da Cunha Serra. São Paulo: Campus, 2004. 471p. Título original: Strategy Maps.

KAPOOR, R.; ADNER, R. Technology interdependence and the evolution of semiconductor lithography. Solid State Technology, p. 51-54, nov 2007.

KATES, A.; GALBRAITH, J. K. Designing your Organization - Using de Star Model to solve five critical design challenges. San Francisco: Jossey-Bass, 2007. $256 \mathrm{p}$.

LAURINDO, F. J. B.; CARVALHO, M. M. Outsourcing e geração de valor na indústria de computadores pessoais (PCs): Estudo de Múltiplos Casos. Gestão e Produção, Vol. 10, No. 3, p. 363-377, 2003. 
; ROTONDARO, R. G. Gestão integrada de processos e da tecnologia da informação. São Paulo: Atlas, 2006. 218 p.

LEITE, L. O.; REZENDE, D. A. Modelo de gestão municipal baseado na utilização estratégica de recursos da tecnologia da informação para a gestão governamental: formatação do modelo e avaliação em um município. Revista de Administração Pública, Vol. 44, No. 2, p. 459-493, 2010.

LEVIN, R. C. The Semiconductor Industry, in Richard R. Nelson, Government and Technical Progress: a Cross-Industry Analysis. New York: Pergamon Press, 1982.

LI, Y. T.; HUANG, M. H.; CHEN, D. Z. Semiconductor industry value chain: characters' technology evolution. Industrial Management \& Data Systems, Vol. 111, No. 3, p. 370-390, 2011.

LIMONGI-FRANÇA, A. C. et al. As Pessoas na Organização. São Paulo: Gente, 2002. $306 \mathrm{p}$.

LOPES, F. D.; BALDI, M. Redes como perspectiva de análise e como estrutura de governança: uma análise das diferentes contribuições. Revista de Administração Pública, Vol. 43, No. 5, p. 1007-1035, 2009.

LUKE, B.; KEARINS, K. VERREYNNE, M. L. The risks and returns of new public management: political business. International Journal of Public Sector Management, Vol. 24, No. 4, p. 325-355, 2011.

MACEDO-SOARES, T. D. L. V. A.; SANTOS, J. A. N. Gestão da mudança estratégica na saúde no Brasil: um modelo para iniciar a implementação de estratégias de qualidade orientadas para o cliente. Revista de Administração Pública, Vol. 35 No. 1, p. 7-27, jan./fev. 2001.

MALERBA, F.; NELSON, R.; ORSENIGO, L.; WINTER, S. Vertical integration and disintegration of computer firms: a history-friendly model of coevolution of the computer and semiconductor industries. Industrial and Corporate Change, Vol. 17, N. 2, p. 197-231, 2008.

in a "history-friendly" model of the co-evolution of the computer and semicondutor industries. Journal of Economic Behavior \& Organization, No. 67, p. 355-380, 2008b. 
MALLAK, L. A.; WATTS, P. S. Delayering in a US Army R\&D organization. The TQM Magazine, Vol. 9, No. 4, p. 260-264, 1997.

McADAM, R.; DONAGHY, J. Business process re-engineering in the public sector - A study of staff perceptions and critical success factors. Business Process Management Journal, Vol. 5 No. 1, p. 33-49, 1999.

; WALKER, T.; HAZLETT, S. A. An inquiry into the strategic-operational role of performance management in local government. International Journal of Public Sector Management, Vol. 24, No. 4, p. 303-324, 2011.

MCTI, 2012, Ministério da Ciência, Tecnologia e Inovação, http://www.inovacaotecnologica.com.br/noticias/noticia.php?artigo=empresasfabrica-semicondutores-brasil\&id=010175120511, consultado em 03/06/12.

MDIC, 2012, Ministério do Desenvolvimento, Indústria e Comércio Exterior, http://www.mdic.gov.br/sistemas web/renai/noticia/conteudo/sq noticia/148, consultado em 27/05/12.

MIGUEL, P. A. C. et al. Metodologia de Pesquisa em Engenharia de Produção e Gestão de Operações. Rio de Janeiro: Elsevier, 2010.

MILES, M. B.; HUBERMAN, A. M. Qualitative Data Analysis - An Expanded Sourcebook, 2a Ed., Sage Publications: Thousand Oaks, 1994. 338 p.

MILLER, J. G. Living Systems: Basic Concepts. Behavioral Science, Vol. 10, p. 193-237, 1965.

MINTZBERG, H. Criando organizações eficazes: estruturas em cinco configurações. Tradução de Ailton Bomfim Brandão. $2^{\underline{a}}$ ed. São Paulo: Atlas, 2009. 334 p. Título original: Structure in fives: designing effective organizations.

MORECROFT, J.; SANCHEZ, R.; HEENE, A. Systems perspectives on resources, capabilities, and management processes. Amsterdam: Pergamon, 2002. 231 p.

MORGAN, G. Imagens da Organização. Tradução de Cecília Whitaker Bergamini e Roberto Coda. São Paulo: Atlas, 1996. 421 p. Título original: Images of Organization. 
MOWERY, D. C.; NELSON, R. R. Sources of Industrial Leadership - Studies of Seven Industries, Cambridge: Cambridge University Press, 1999. 401 p.

MUSCAT, A. R. N. Modelo para Integração de Decisões sobre Sistemas de Operações. 1993. 258 p. Tese (Doutorado) - Escola Politécnica, Universidade de São Paulo, São Paulo, 1993.

; FLEURY, A. C. C. Indicadores da Qualidade e Produtividade na Indústria Brasileira, Revista Indicadores da Qualidade e Produtividade, São Paulo, p. 82-107, 1993.

; BIAZZI, M. R.; MIGUEL, P. A. C. Implementação da estratégia utilizando BSC: um estudo de caso no setor público brasileiro, GEPROS - Gestão da Produção, Operações e Sistemas, Ano 2, Vol. 3, p. 35-47, 2007.

NADLER, D. A.; GERSTEIN, M. S.; SHAW, R. B. Arquitetura Organizacional. Rio de Janeiro: Campus. Tradução de Waltensir Dutra, 1994. 265 p.

NIKOLOPOULOS, K., METAXIOTIS, K., LEKATIS, N., ASSIMAKOPOULOS, V. Integrating Industrial Maintenance Strategy into ERP, Industrial Management \& Data Systems, Vol.103, No.3, pp. 184-191, 2003.

NEWMAN, P. Understanding city-regional cooperation: what works where. International Journal of Public Sector Management, Vol. 22, No. 3, p. 183-191, 2009.

NOLAN, R. L.; CROSSON, D. C. Destruição Criativa. Rio de Janeiro: Campus. Tradução de Priscilla Martins Celeste e Ana Beatriz Rodrigues, 1996. 314 p.

ONGARO, E. Process management in the public sector - The experience of one-stop shops in Italy. The International Journal of Public Sector Management, Vol. 17 No. 1, p. 81-107, 2004.

OOI, K. B.; BAKAR, N. A.; ARUMUGAM, V.; VELLAPAN, L.; LOKE, A. K. Y. Does TQM influence employees' job satisfaction? An empirical case analysis. International Journal of Quality \& Reliability Management, Vol. 24, No. 1, p. 62-77, 2007. 
OSBORNE, D.; GAEBLER, T. Reinventing Government - How the entrepreneurial spirit is transforming the public sector. New York: Penguin Books USA Inc., 1992. $405 \mathrm{p}$.

OTHMAN, R.; SAID, J. Enhancing control through participation: Issues of conflicts in public sector organizations. Journal of Financial Reporting \& Accounting, Vol. 5, No. 1, p. 71-86, 2007.

PORTER, M. E. Estratégia Competitiva. Rio de Janeiro: Campus. Tradução de Elizabeth Maria de Pinho Braga, 2004. 409p. Título original: Competitive Strategy.

. Competição $=$ On Competition. Rio de Janeiro: Campus, 2009. 546p. Título original: On Competition.

PRAHALAD, C. K.; HAMEL, G. Competindo pelo futuro: Estratégias inovadoras para manter o controle de seu setor e criar os mercados de amanhã. $25^{\mathrm{a}} \mathrm{Ed}$. Rio de Janeiro: Campus. Tradução de Outras Palavras, 2005. 373p.

RADNOR, Z.; LOVELL, B. Success Factors for implementation of the balanced scorecard in a NHS multi-agency setting. International Journal of Health Care Quality Assurance, V. 16, N. 2, p. 99-108, 2003.

ROBBINS, S. P. Comportamento Organizacional. São Paulo: Pearson Prentice Hall, 2005. 637 p.

ROCHA, C. B.; SILVA, J. R. G. Identificação de funcionários com empresa pública no contexto de mudanças: o caso Finep. Revista de Administração Pública, Vol. 41, No. 4, p. 685-706, 2007.

RUTKOWSKI, J. Qualidade no serviço público - Um estudo de caso. Gestão e Produção, Vol. 5. No. 3, p. 284-297, 1998.

RYAN, N.; WILLIAMS, T.; CHARLES, M.; WATERHOUSE, J. Top-down organizational change in a Australian Government agency. International Journal of Public Sector Management, Vol. 21, No. 1, p. 26-44, 2008.

SAXENIAN, A. Regional Advantage: Culture and Competition in Silicon Valley and Route 128. Cambridge, Massachussets: Harvard University Press, 1994. 
SCHEIN, E. H. Organizational Culture and Leadership. San Francisco: JosseyBass, 2010. $4^{\mathrm{a}}$ ed. $436 \mathrm{p}$.

SCHRAEDER, M.; TEARS, R. S.; JORDAN, M. H. Organizational Culture in public sector organizations. Leadership \& Organization Development Journal, Vol. 26, No. 6, p. 492-502, 2005.

SEBRAE, $2011 \quad$ - $\quad$ http://www.mundosebrae.com.br/2009/09/o-que-e-um-apl/ consultado em 21/10/11.

SECCHI, L. Modelos organizacionais e reformas da administração pública. Revista de Administração Pública, Vol. 43, No. 2, p. 347-369, 2009.

SLACK, N. Vantagem Competitiva em Manufatura - Atingindo Competitividade nas Operações Industriais. São Paulo: Atlas, 2002. $2^{a}$ ed. 218 p.

STACEY, R. D. Complexity and management: fad or radical challenge to systems thinking? London: Routledge, 2000. 224 p.

STERMAN, J. Business dynamics: systems thinking and modeling for a complex world. Boston: McGraw-Hill, 2000. 982 p.

TECNOLOGIA TERRA, 30/12/2011 http://tecnologia.terra.com.br/robotica/ noticias $/ 0,015535945$-El18825,00-Brasil+avanca+em+robotica+mas +ainda+sofre +com+infraestrutura.html, consultado em 27/05/12.

TODOROVICH, P. America's emerging megaregions and implications for a national growth strategy. International Journal of Public Sector Management, Vol. 22, No. 3, p. 221-234, 2009.

TURBAN, E.; RAINER Jr., R. K.; POTTER, R. E. Administração da Tecnologia da Informação - Teoria e Prática. São Paulo: Campus, 2003. 598 p.

TROSHANI, I.; JERRAM, C.; HILL, S. R. Exploring the public sector adoption of HRIS. Industrial Management \& Data Systems, Vol. 111, No. 3, p. 470-488, 2011. 
UBEDA, C. L.; SANTOS, F. C. A. Os principais desafios da gestão de competências humanas em um instituto público de pesquisa. Gestão e Produção, Vol. 15, No. 1, p. 189-199, 2008.

VASCONCELLOS, E.; HEMSLEY, J. R. Estrutura das Organizações. São Paulo: Thomson Pioneira, 4⿳亠丷厂 ed, 2002. 207 p.

VAZ, J. C.; LOTTA, G. S. A contribuição da logística integrada às decisões de gestão das políticas públicas no Brasil. Revista de Administração Pública, Vol. 45, No. 1, p. 107-139, 2011.

VERBEETEN, F. Public sector cost management practices in the Netherlands. International Journal of Public Sector Management, Vol. 4, No. 6, 2011.

VIGODA-GADOT, E. Leadership style, organizational politics, and employees' performance. Personnel Review, Vol. 36, No. 5, p. 661-683, 2006.

VILLARDI, B. Q.; FERRAZ, V. N.; DUBEUX, V. J. C. Uma metodologia para diagnóstico de clima organizacional: integrando motivos sociais e cultura brasileira com fatores do ambiente de trabalho do Poder Judiciário. Revista de Administração Pública, Vol. 45, No. 2, p. 303-329, 2011.

VOSS, C.; TSIKRIKTSIS, N.; FROHLICH, M. Case research in operations management. International Journal of Operations \& Production Management, Vol. 22 No. 2, p. 195-219, 2002.

WATERMAN, R. H. Jr. O Fator Renovação. São Paulo: Harbra. Tradução de Nivaldo Montingelli Jr., 1989. 330 p.

WEBER, M. A Ética Protestante e o Espírito do Capitalismo. São Paulo: Cengage Learning, $2^{\mathrm{a}}$ ed., 2008, $187 \mathrm{p}$.

WILSON, C.; HAGARTY, D.; GAUTHIER, J. Results using the balanced scorecard in the public sector. Journal of Corporate Real Estate, V. 6, N. 1, p. 53-63, 2003.

YIN, R. K. Estudo de Caso: Planejamento e Métodos. Porto Alegre: Bookman, $4^{\mathrm{a}}$ ed. Tradução de Ana Thorell, 2010. 248 p. 
YOFFIE, D. B. How an industry builds political advantage: the politics of business. Harvard Business Review, V. 66, N. 3, p. 82-89, mai-jun 1988.

ZEXIAN, Y.; XUHUI, Y. A Revolution in the Field of Systems Thinking - a Review of Checkland's System Thinking. Systems Research and Behavioral Science, Vol. 27, p. 140-155, 2010. 


\section{ANEXO A - Funções em Comissão}

\begin{tabular}{|c|c|}
\hline Posição & Valor de Referência (R\$) \\
\hline Superintendente & $14.700,00$ \\
\hline Gerente de Departamento I & $11.900,00$ \\
\hline Gerente de Departamento II & $9.380,00$ \\
\hline Gerente de Divisão I & $7.490,00$ \\
\hline Gerente de Divisão II & $6.020,00$ \\
\hline Consultor Técnico I & $11.900,00$ \\
\hline Consultor Técnico II & $9.380,00$ \\
\hline Consultor Técnico III & $7.490,00$ \\
\hline Assessor da Presidência & $9.380,00$ \\
\hline Assessor de Diretoria & $7.490,00$ \\
\hline Secretaria da Presidência & $3.080,00$ \\
\hline Secretaria de Diretoria & $2.450,00$ \\
\hline Auditor & $7.490,00$ \\
\hline Assistente Técnico I & $6.020,00$ \\
\hline Assistente Técnico II & $4.760,00$ \\
\hline Assistente Técnico III & $3.850,00$ \\
\hline Supervisor de Fábrica I & $3.080,00$ \\
\hline Supervisor de Fábrica II & $2.450,00$ \\
\hline
\end{tabular}

Obs: Valores fictícios, baseados nos valores reais. 


\section{ANEXO B - Desdobramento de Macroprocessos em Processos e Subprocessos}

\begin{tabular}{|c|c|c|c|}
\hline No & Macroprocesso & Processo & Subprocesso \\
\hline 1 & Design & Desenvolvimento de Sistemas Hardware & \\
\hline 2 & Design & Projetos Analógicos & \\
\hline 3 & Design & Rádio-frequência & \\
\hline 4 & Design & Suporte e Infraestrutura de Ferramentas de Design & \\
\hline 5 & Fabricação & Segurança Operacional (Health \& Safety) & \\
\hline 6 & Fabricação & Engenharia de Processo & Fotogravação \\
\hline 7 & Fabricação & Engenharia de Processo & Limpeza Química \\
\hline 8 & Fabricação & Engenharia de Processo & Difusão \\
\hline 9 & Fabricação & Engenharia de Processo & Implantação \\
\hline 10 & Fabricação & Engenharia de Processo & Etching \\
\hline 11 & Fabricação & Engenharia de Processo & Filmes Finos \\
\hline 12 & Fabricação & Engenharia de Processo & Probe \\
\hline 13 & Fabricação & Produção & \\
\hline 14 & Fabricação & Manutenção Operacional & Manutenção de Equipamentos \\
\hline 15 & Fabricação & Manutenção Operacional & Manutenção de Facilities \\
\hline 16 & Fabricação & Logística & Planejamento Programação e Controle da Produção (PPCP) \\
\hline 17 & Fabricação & Logística & Materiais \\
\hline 18 & Fabricação & Logística & Almoxarifado \\
\hline 19 & Fabricação & Qualidade de Produção & Inspeção de Entrada \\
\hline 20 & Fabricação & Qualidade de Produção & Qualidade de Processo de Produção \\
\hline 21 & Fabricação & Qualidade de Produção & Inspeção Final \\
\hline 22 & Supply Chain & $\begin{array}{l}\text { Sourcing - Identificação, Seleção e Avaliação de } \\
\text { Fontes de Suprimentos }\end{array}$ & \\
\hline 23 & Supply Chain & Desenvolvimento de Fornecedor & \\
\hline 24 & Supply Chain & Gestão da Demanda de Clientes & \\
\hline 25 & Supply Chain & Gestão da Oferta de Fornecedores & \\
\hline 26 & Supply Chain & Gestão da Malha Logística & Logística Inbound (de Entradas) \\
\hline 27 & Supply Chain & Gestão da Malha Logística & Logística Outbound (de Saídas) \\
\hline 28 & Supply Chain & Logística de Assistência Técnica & \\
\hline 29 & Terceirização da Fabricação & & \\
\hline 30 & Pesquisa & Acompanhamento de Publicações & \\
\hline
\end{tabular}




\begin{tabular}{|c|c|c|c|}
\hline 31 & Pesquisa & Identificação de Necessidades de Pesquisa & \\
\hline 32 & Pesquisa & Articulação com grupos externos (Parceiros) & \\
\hline 33 & Pesquisa & Prospecção Tecnológica & \\
\hline 34 & Pesquisa & $\begin{array}{l}\text { Transferência de Tecnologia de fora para a } \\
\text { Organização A (projeto) }\end{array}$ & \\
\hline 35 & $\begin{array}{l}\text { Desenvolvimento de Produtos } \\
\text { e Negócios }\end{array}$ & Prospecção de Negócios & \\
\hline 36 & $\begin{array}{l}\text { Desenvolvimento de Produtos } \\
\text { e Negócios }\end{array}$ & $\begin{array}{l}\text { Proposta de Negócios - Desenvolvimento de Novo } \\
\text { Chip }\end{array}$ & \\
\hline 37 & $\begin{array}{l}\text { Desenvolvimento de Produtos } \\
\text { e Negócios }\end{array}$ & $\begin{array}{l}\text { Proposta de Negócios - Chip em Fase de } \\
\text { Produção }\end{array}$ & \\
\hline 38 & $\begin{array}{l}\text { Desenvolvimento de Produtos } \\
\text { e Negócios }\end{array}$ & Planejamento Financeiro de Operações e Vendas & \\
\hline 39 & $\begin{array}{l}\text { Desenvolvimento de Produtos } \\
\text { e Negócios }\end{array}$ & Acompanhamento de Negócios & \\
\hline 40 & $\begin{array}{l}\text { Desenvolvimento de Produtos } \\
\text { e Negócios }\end{array}$ & Fechamento de Contrato ou Convênio & \\
\hline 41 & $\begin{array}{l}\text { Desenvolvimento de Produtos } \\
\text { e Negócios }\end{array}$ & Marketing & \\
\hline 42 & $\begin{array}{l}\text { Desenvolvimento de Produtos } \\
\text { e Negócios }\end{array}$ & Relações Institucionais & Órgãos de Fomento \\
\hline 43 & $\begin{array}{l}\text { Desenvolvimento de Produtos } \\
\text { e Negócios }\end{array}$ & Pós-Venda & \\
\hline 44 & $\begin{array}{l}\text { Desenvolvimento de Produtos } \\
\text { e Negócios }\end{array}$ & Relações Institucionais & Instituições de Ensino \\
\hline 45 & Fomento & Formação de Recursos Humanos & $\mathrm{RH}$ existente na empresa (cursos de aperfeiçoamento) \\
\hline 46 & Fomento & Formação de Recursos Humanos & Preparação de $\mathrm{RH}$ qualificado $\mathrm{p}$ / futuro \\
\hline 47 & Fomento & Formação de Alianças Estratégicas & \\
\hline 48 & Fomento & Formação de Arranjo Produtivo Regional & \\
\hline 49 & Governança & Gestão Estratégica & Planejamento Estratégico \\
\hline 50 & Governança & Gestão Estratégica & Acompanhamento e Análise do Planejamento Estratégico \\
\hline 51 & Governança & Reuniões com Conselhos & Conselho Fiscal \\
\hline 52 & Governança & Reuniões com Conselhos & Conselho de Administração \\
\hline 53 & Governança & Reuniões com Conselhos & Conselho Consultivo \\
\hline 54 & Governança & Gestão Estratégica & Plano de Investimentos \\
\hline 55 & Governança & Gestão Estratégica & Plano de Negócios \\
\hline
\end{tabular}




\begin{tabular}{|c|c|c|c|}
\hline 56 & Governança & Relações Interinstitucionais & Governo \\
\hline 57 & Governança & Relações Interinstitucionais & Empresas \\
\hline 58 & Governança & Relações Interinstitucionais & Centros de Pesquisa \\
\hline 59 & Governança & Relações Interinstitucionais & Órgãos de Fomento \\
\hline 60 & Governança & Relações Interinstitucionais & Órgãos de Comunicação \\
\hline 61 & Governança & Reuniões de Diretoria & \\
\hline 62 & Governança & Sucessão & \\
\hline 63 & $\begin{array}{l}\text { Secretaria Executiva da } \\
\text { Presidência } \\
\end{array}$ & Agenda do Presidente & \\
\hline 64 & $\begin{array}{l}\text { Secretaria Executiva da } \\
\text { Presidência }\end{array}$ & Elaboração e Controle de Ofícios & \\
\hline 65 & $\begin{array}{l}\text { Secretaria Executiva da } \\
\text { Presidência }\end{array}$ & Recepção & \\
\hline 66 & $\begin{array}{l}\text { Secretaria Executiva da } \\
\text { Presidência }\end{array}$ & Ouvidoria & \\
\hline 67 & $\begin{array}{l}\text { Secretaria Executiva da } \\
\text { Presidência }\end{array}$ & Agenda de Motoristas & \\
\hline 68 & $\begin{array}{l}\text { Secretaria Executiva da } \\
\text { Presidência }\end{array}$ & Acompanhamento da Limpeza & \\
\hline 69 & $\begin{array}{l}\text { Secretaria Executiva da } \\
\text { Presidência }\end{array}$ & Atendimento a Demandas Diversas & \\
\hline 70 & Orçamento e Finanças & Pré-empenho e Nota de Empenho & \\
\hline 71 & Orçamento e Finanças & Liquidação (Provisão do Pagamento) & \\
\hline 72 & Orçamento e Finanças & Pagamento & \\
\hline 73 & Orçamento e Finanças & Planejamento Orçamentário & \\
\hline 74 & Orçamento e Finanças & Fechamento de Câmbio & \\
\hline 75 & Orçamento e Finanças & Pagamento de Funcionários & \\
\hline 76 & Orçamento e Finanças & Administração do Fundo Fixo & \\
\hline 77 & Orçamento e Finanças & Gestão do Fluxo de Caixa & \\
\hline 78 & Orçamento e Finanças & Elaboração de Relatórios & \\
\hline 79 & Contabilidade & Contabilização & \\
\hline 80 & Contabilidade & Elaboração de Obrigações Acessórias & \\
\hline 81 & Contabilidade & Elaboração de Demonstrações Contábeis Mensais & \\
\hline 82 & Contabilidade & Apuração de Impostos antes dos Pagamentos & \\
\hline 83 & Contabilidade & Conciliação entre Contabilidade Societária e SIAFI & \\
\hline
\end{tabular}




\begin{tabular}{|c|c|c|c|}
\hline 84 & Contabilidade & Declaração de Imposto de Renda Pessoa Jurídica & \\
\hline 85 & Contabilidade & Inteligência Fiscal & \\
\hline 86 & Contabilidade & Elaboração de Demonstração Contábil Anual & \\
\hline 87 & Contabilidade & Conciliação entre Contábil e Fiscal & \\
\hline 88 & Contabilidade & Conciliação entre Contábil e Patrimônio & \\
\hline 89 & Contabilidade & Apuração de Impostos após Conciliação & \\
\hline 90 & Contabilidade & Assessoria Contábil-fiscal para as áreas & \\
\hline 91 & Contabilidade & Atendimento à Auditoria Externa & \\
\hline 92 & Contabilidade & Atendimento à Auditoria Interna & \\
\hline 93 & Compras e Importação & Almoxarifado & Cadastro de Produtos \\
\hline 94 & Compras e Importação & Almoxarifado & Controle de Prazos de Entregas \\
\hline 95 & Compras e Importação & Almoxarifado & Recebimento de Materiais \\
\hline 96 & Compras e Importação & Almoxarifado & Requisição de Materiais ao Almoxarifado \\
\hline 97 & Compras e Importação & Almoxarifado & Controle de Estoque \\
\hline 98 & Compras e Importação & Cadastro Patrimonial & \\
\hline 99 & Compras e Importação & Controle Patrimonial & \\
\hline 100 & Compras e Importação & Elaboração de Contratos & \\
\hline 101 & Compras e Importação & Controle de Contratos Vigentes & \\
\hline 102 & Compras e Importação & Compras - Dispensa de Valor & \\
\hline 103 & Compras e Importação & Compras - Carta Convite & \\
\hline 104 & Compras e Importação & Compras - Tomada de Preços ou Concorrência & \\
\hline 105 & Compras e Importação & Compras - Pregão Eletrônico ou Presencial & \\
\hline 106 & Compras e Importação & Compras - Inexigibilidade & \\
\hline 107 & Compras e Importação & Compras - Internacionais & \\
\hline 108 & Gestão de Pessoas & Folha de Pagamentos & \\
\hline 109 & Gestão de Pessoas & Recrutamento e Seleção & \\
\hline 110 & Gestão de Pessoas & Treinamento e Desenvolvimento & \\
\hline 111 & Gestão de Pessoas & Administração e Controle de Pessoal & \\
\hline 112 & Gestão de Pessoas & $\begin{array}{l}\text { Gestão de Carreira e Estudos e Normas de } \\
\text { Pessoal }\end{array}$ & \\
\hline 113 & Gestão de Pessoas & Avaliação de Pessoal & \\
\hline 114 & Gestão de Pessoas & Acompanhamento de Pessoal & \\
\hline 115 & Gestão de Pessoas & Segurança do Trabalho (Gestão administrativa) & \\
\hline
\end{tabular}




\begin{tabular}{|c|c|c|c|}
\hline 116 & Gestão de Pessoas & Manutenção do Cadastro de Pessoal & \\
\hline 117 & Gestão de Pessoas & $\begin{array}{l}\text { Integração de Novos Colaboradores } \\
\text { (Ambientação) }\end{array}$ & \\
\hline 118 & $\begin{array}{l}\text { Serviços Gerais de Apoio } \\
\text { Administrativo }\end{array}$ & Infra-estrutura Predial & Manutenção Predial \\
\hline 119 & $\begin{array}{l}\text { Serviços Gerais de Apoio } \\
\text { Administrativo }\end{array}$ & Segurança Patrimonial & Portaria - Visitante \\
\hline 120 & $\begin{array}{l}\text { Serviços Gerais de Apoio } \\
\text { Administrativo }\end{array}$ & Segurança Patrimonial & Portaria - Prestador de Serviços \\
\hline 121 & $\begin{array}{l}\text { Serviços Gerais de Apoio } \\
\text { Administrativo }\end{array}$ & Apoio a Viagens & Passagens \\
\hline 122 & $\begin{array}{l}\text { Serviços Gerais de Apoio } \\
\text { Administrativo }\end{array}$ & Serviços Gerais & Refeitório \\
\hline 123 & $\begin{array}{l}\text { Serviços Gerais de Apoio } \\
\text { Administrativo }\end{array}$ & Infra-estrutura Predial & Instalações Elétricas \\
\hline 124 & $\begin{array}{l}\text { Serviços Gerais de Apoio } \\
\text { Administrativo }\end{array}$ & Segurança Patrimonial & Controle de Crachás \\
\hline 125 & $\begin{array}{l}\text { Serviços Gerais de Apoio } \\
\text { Administrativo }\end{array}$ & Segurança Patrimonial & Acesso Físico de Pessoas \\
\hline 126 & $\begin{array}{l}\text { Serviços Gerais de Apoio } \\
\text { Administrativo }\end{array}$ & Apoio a Viagens & Hospedagem \\
\hline 127 & $\begin{array}{l}\text { Serviços Gerais de Apoio } \\
\text { Administrativo }\end{array}$ & Apoio a Viagens & Vistos \\
\hline 128 & $\begin{array}{l}\text { Serviços Gerais de Apoio } \\
\text { Administrativo }\end{array}$ & Apoio a Viagens & Relatório de Despesas \\
\hline 129 & $\begin{array}{l}\text { Serviços Gerais de Apoio } \\
\text { Administrativo }\end{array}$ & Serviços Gerais & Motorista \\
\hline 130 & $\begin{array}{l}\text { Serviços Gerais de Apoio } \\
\text { Administrativo }\end{array}$ & Segurança Patrimonial & Vigilância \\
\hline 131 & $\begin{array}{l}\text { Serviços Gerais de Apoio } \\
\text { Administrativo }\end{array}$ & Segurança Patrimonial & Recepção \\
\hline 132 & $\begin{array}{l}\text { Serviços Gerais de Apoio } \\
\text { Administrativo }\end{array}$ & Segurança Patrimonial & Controle de Entrada e Saída de Veículos \\
\hline 133 & $\begin{array}{l}\text { Serviços Gerais de Apoio } \\
\text { Administrativo }\end{array}$ & Segurança Patrimonial & Controle de Entrada e Saída de Equipamentos \\
\hline 134 & $\begin{array}{l}\text { Serviços Gerais de Apoio } \\
\text { Administrativo }\end{array}$ & Segurança Patrimonial & Acesso Físico de Materiais \\
\hline
\end{tabular}




\begin{tabular}{|c|c|c|c|}
\hline 135 & $\begin{array}{l}\text { Serviços Gerais de Apoio } \\
\text { Administrativo }\end{array}$ & Segurança Patrimonial & Monitoramento por Câmeras \\
\hline 136 & $\begin{array}{l}\text { Serviços Gerais de Apoio } \\
\text { Administrativo }\end{array}$ & Infra-estrutura Predial & Instalações de Móveis \\
\hline 137 & $\begin{array}{l}\text { Serviços Gerais de Apoio } \\
\text { Administrativo }\end{array}$ & Infra-estrutura Predial & Salas de Reunião, Auditório e Vídeo-conferência \\
\hline 138 & $\begin{array}{l}\text { Serviços Gerais de Apoio } \\
\text { Administrativo }\end{array}$ & Serviços Gerais & Copa \\
\hline 139 & $\begin{array}{l}\text { Serviços Gerais de Apoio } \\
\text { Administrativo }\end{array}$ & Serviços Gerais & Limpeza \\
\hline 140 & $\begin{array}{l}\text { Serviços Gerais de Apoio } \\
\text { Administrativo }\end{array}$ & Serviços Gerais & Jardinagem \\
\hline 141 & $\begin{array}{l}\text { Tecnologia de Informação e } \\
\text { Telecomunicação }\end{array}$ & Segurança da Informação e Comunicações & \\
\hline 142 & $\begin{array}{l}\text { Tecnologia de Informação e } \\
\text { Telecomunicação }\end{array}$ & 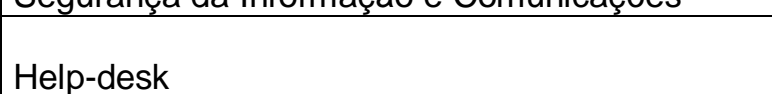 & \\
\hline 143 & $\begin{array}{l}\text { Tecnologia de Informação e } \\
\text { Telecomunicação }\end{array}$ & Serviços de Internet & Acesso externo \\
\hline 144 & $\begin{array}{l}\text { Tecnologia de Informação e } \\
\text { Telecomunicação }\end{array}$ & Serviços de Internet & E-mail \\
\hline 145 & $\begin{array}{l}\text { Tecnologia de Informação e } \\
\text { Telecomunicação }\end{array}$ & Serviços de Internet & Internet \\
\hline 146 & $\begin{array}{l}\text { Tecnologia de Informação e } \\
\text { Telecomunicação }\end{array}$ & Serviços de Internet & Proxi \\
\hline 147 & $\begin{array}{l}\text { Tecnologia de Informação e } \\
\text { Telecomunicação }\end{array}$ & Serviços de Internet & Usuário de rede \\
\hline 148 & $\begin{array}{l}\text { Tecnologia de Informação e } \\
\text { Telecomunicação }\end{array}$ & Serviço de celulares & \\
\hline 149 & $\begin{array}{l}\text { Tecnologia de Informação e } \\
\text { Telecomunicação }\end{array}$ & Infraestrutura de Rede & \\
\hline 150 & $\begin{array}{l}\text { Tecnologia de Informação e } \\
\text { Telecomunicação }\end{array}$ & Infraestrutura de Internet & \\
\hline 151 & $\begin{array}{l}\text { Tecnologia de Informação e } \\
\text { Telecomunicação }\end{array}$ & Gestão de Servidores, Workstation e Notebooks & \\
\hline 152 & $\begin{array}{l}\text { Tecnologia de Informação e } \\
\text { Telecomunicação }\end{array}$ & Apoio às áreas & \\
\hline 153 & $\begin{array}{l}\text { Tecnologia de Informação e } \\
\text { Telecomunicação }\end{array}$ & Serviço de telefonia interno & \\
\hline
\end{tabular}




\begin{tabular}{|c|c|c|c|}
\hline 154 & Normas e Processos & Sistema de Gestão da Qualidade & Certificações Técnicas \\
\hline 155 & Normas e Processos & $\begin{array}{l}\text { Mapeamento de Processos (de Negócios e de } \\
\text { Suporte) }\end{array}$ & Mapeamento \\
\hline 156 & Normas e Processos & $\begin{array}{l}\text { Mapeamento de Processos (de Negócios e de } \\
\text { Suporte) }\end{array}$ & Formatação de Padrões \\
\hline 157 & Normas e Processos & $\begin{array}{l}\text { Mapeamento de Processos (de Negócios e de } \\
\text { Suporte) }\end{array}$ & Manutenção dos Processos definidos \\
\hline 158 & Normas e Processos & Melhoria de Processos (de Negócios e de Suporte) & Busca de soluções \\
\hline 159 & Normas e Processos & Melhoria de Processos (de Negócios e de Suporte) & Prospecção de Modelos de Gestão \\
\hline 160 & Normas e Processos & Melhoria de Processos (de Negócios e de Suporte) & Sistema de Gestão Integrado \\
\hline 161 & Normas e Processos & Melhoria de Processos (de Negócios e de Suporte) & PGQP \\
\hline 162 & Normas e Processos & Sistema de Gestão da Qualidade & ISO9001 \\
\hline 163 & Normas e Processos & Sistema de Gestão Ambiental & ISO14001 \\
\hline 164 & Normas e Processos & Sistema de Gestão Ambiental & $\begin{array}{l}\text { Definição, Controle e Manutenção de aspectos e impactos } \\
\text { ambientais }\end{array}$ \\
\hline 165 & Normas e Processos & Sistema de Gestão da Qualidade & Auditorias Internas \\
\hline 166 & Normas e Processos & Sistema de Gestão da Qualidade & Auditorias Externas \\
\hline 167 & Normas e Processos & Sistema de Gestão Ambiental & Auditorias internas \\
\hline 168 & Normas e Processos & Sistema de Gestão Ambiental & Auditorias externas \\
\hline 169 & Normas e Processos & Gestão Documental & Arquivo \\
\hline 170 & Normas e Processos & Gestão Documental & Protocolo \\
\hline 171 & Normas e Processos & Gestão Documental & Atos Oficiais \\
\hline 172 & Normas e Processos & Gestão Documental & Biblioteca \\
\hline 173 & Comunicação Corporativa & Relações Públicas & Organização de Eventos \\
\hline 174 & Comunicação Corporativa & Jornalismo & Redação de Releases \\
\hline 175 & Comunicação Corporativa & Patrocínio & \\
\hline 176 & Comunicação Corporativa & Relações Públicas & Imagem Pública \\
\hline 177 & Comunicação Corporativa & Relações Públicas & Relações Interinstitucionais \\
\hline 178 & Comunicação Corporativa & Relações Públicas & Relações Governamentais \\
\hline 179 & Comunicação Corporativa & Relações Públicas & Responsabilidade Social \\
\hline 180 & Comunicação Corporativa & Jornalismo & Newsletter eletrônica \\
\hline 181 & Comunicação Corporativa & Jornalismo & Redes Sociais (ideal) \\
\hline 182 & Comunicação Corporativa & Comunicação Interna & \\
\hline 183 & Comunicação Corporativa & Endomarketing & \\
\hline
\end{tabular}




\begin{tabular}{|c|c|c|c|}
\hline 184 & Comunicação Corporativa & Jornalismo & Análise Editorial \\
\hline 185 & Comunicação Corporativa & Jornalismo & Fotos Jornalísticas \\
\hline 186 & Comunicação Corporativa & Jornalismo & Acompanhamento de Entrevistas \\
\hline 187 & Comunicação Corporativa & Publicidade & Criação de Material Publicitário \\
\hline 188 & Comunicação Corporativa & Publicidade & Fotos Publicitárias \\
\hline 189 & Comunicação Corporativa & Publicidade & Edição de Imagens \\
\hline 190 & Comunicação Corporativa & Publicidade & Marca e Identidade Visual \\
\hline 191 & Comunicação Corporativa & Gestão do Site & \\
\hline 192 & Jurídico & Consultoria Jurídica (Apoio às diversas áreas) & \\
\hline 193 & Jurídico & Contencioso Administrativo & \\
\hline 194 & Jurídico & Contencioso Judicial & \\
\hline 195 & Jurídico & Elaboração de Contratos & \\
\hline 196 & Jurídico & Assessoria a Compras & \\
\hline 197 & Jurídico & Acompanhamento de Publicação de Leis & \\
\hline 198 & Jurídico & $\begin{array}{l}\text { Acompanhamento de Processos em Tramitação } \\
\text { no Legislativo }\end{array}$ & \\
\hline 199 & Jurídico & Averbação de Contratos & \\
\hline 200 & Jurídico & Apoio Institucional & \\
\hline 201 & Auditoria Interna & Interface Institucional & \\
\hline 202 & Auditoria Interna & $\begin{array}{l}\text { Elaboração de Parecer Prévio sobre Prestação de } \\
\text { Contas Anual }\end{array}$ & \\
\hline 203 & Auditoria Interna & Elaboração do Plano Anual de Auditoria Interna & \\
\hline 204 & Auditoria Interna & $\begin{array}{l}\text { Acompanhamento e Avaliação da Execução do } \\
\text { Plano Anual }\end{array}$ & \\
\hline 205 & Auditoria Interna & Análise e Avaliação da Execução Orçamentária & \\
\hline 206 & Auditoria Interna & Apoio e Assessoria da Gestão Orçamentária & \\
\hline 207 & Auditoria Interna & Apoio e Assessoria da Gestão Financeira & \\
\hline 208 & Auditoria Interna & Apoio e Assessoria da Gestão Patrimonial & \\
\hline 209 & Auditoria Interna & Apoio e Assessoria da Gestão de RH & \\
\hline 210 & Auditoria Interna & Avaliação dos Processos Organizacionais & \\
\hline 211 & Auditoria Interna & $\begin{array}{l}\text { Acompanhamento e Avaliação de Projetos e } \\
\text { Ações }\end{array}$ & \\
\hline
\end{tabular}

Fonte: Elaborado pela autora 


\section{ANEXO C - Lista de Processos e Subprocessos Priorizados}

\begin{tabular}{|c|c|c|c|}
\hline & Macroprocesso & Processo & Subprocesso \\
\hline 1 & Desenvolvimento de Produtos e Negócios & Prospecção de Negócios & \\
\hline 2 & Desenvolvimento de Produtos e Negócios & Proposta de Negócios - Desenvolvimento de Novo Chip & \\
\hline 3 & Desenvolvimento de Produtos e Negócios & Proposta de Negócios - Chip em Fase de Produção & \\
\hline 4 & Orçamento e Finanças & Pré-empenho e Nota de Empenho & \\
\hline 5 & Orçamento e Finanças & Liquidação (Provisão do Pagamento) & \\
\hline 6 & Orçamento e Finanças & Pagamento & \\
\hline 7 & Contabilidade & Contabilização & \\
\hline 8 & Contabilidade & Elaboração de Obrigações Acessórias & \\
\hline 9 & Gestão de Pessoas & Folha de Pagamentos & \\
\hline 10 & Gestão de Pessoas & Recrutamento e Seleção & \\
\hline 11 & $\begin{array}{l}\text { Tecnologia de Informação e } \\
\text { Telecomunicação }\end{array}$ & Segurança da Informação e Comunicações & \\
\hline 12 & Comunicação Corporativa & Relações Públicas & Organização de Eventos \\
\hline 13 & Jurídico & Consultoria Jurídica (Apoio às diversas áreas) & \\
\hline 14 & Auditoria Interna & Interface Institucional & \\
\hline 15 & Governança & Gestão Estratégica & $\begin{array}{l}\text { Acompanhamento e Análise do Planejamento } \\
\text { Estratégico }\end{array}$ \\
\hline 16 & Serviços Gerais de Apoio Administrativo & Infra-estrutura Predial & Manutenção Predial \\
\hline 17 & $\begin{array}{l}\text { Tecnologia de Informação e } \\
\text { Telecomunicação }\end{array}$ & Help-desk & \\
\hline 18 & Auditoria Interna & $\begin{array}{l}\text { Elaboração de Parecer Prévio sobre Prestação de } \\
\text { Contas Anual }\end{array}$ & \\
\hline 19 & Serviços Gerais de Apoio Administrativo & Segurança Patrimonial & Portaria - Visitante \\
\hline 20 & Serviços Gerais de Apoio Administrativo & Segurança Patrimonial & Portaria - Prestador de Serviços \\
\hline 21 & Compras e Importação & Almoxarifado & Controle de Entregas \\
\hline 22 & Compras e Importação & Cadastro Patrimonial & \\
\hline 23 & Compras e Importação & Almoxarifado & Cadastro de Produtos \\
\hline 24 & Compras e Importação & Almoxarifado & Recebimento de Materiais \\
\hline 25 & Compras e Importação & Almoxarifado & Devolução de Materiais \\
\hline 26 & Compras e Importação & Almoxarifado & Requisição de Materiais ao Almoxarifado \\
\hline 27 & Serviços Gerais de Apoio Administrativo & Serviços Gerais & Refeitório \\
\hline
\end{tabular}


\begin{tabular}{|l|l|}
28 & Design \\
\hline 29 & Orçament \\
\hline
\end{tabular}

29 Orçamento e Finanças

30 Gestão de Pessoas

31 Desenvolvimento de Produtos e Negócios

32 Governança

33 Governanca

34 Serviços Gerais de Apoio Administrativo

35 Orçamento e Finanças

36 Contabilidade

Fonte: Elaborado pela autora
Desenvolvimento de Sistemas Hardware

Planejamento Orçamentário

Treinamento e Desenvolvimento

Acompanhamento de Negócios

Reuniões com Conselhos

Reuniões com Conselhos

Conselho Fiscal

Conselho de Administração

Controle de Crachás

\section{Fechamento de Câmbio}

Elaboração de Demonstrações Contábeis Mensais 


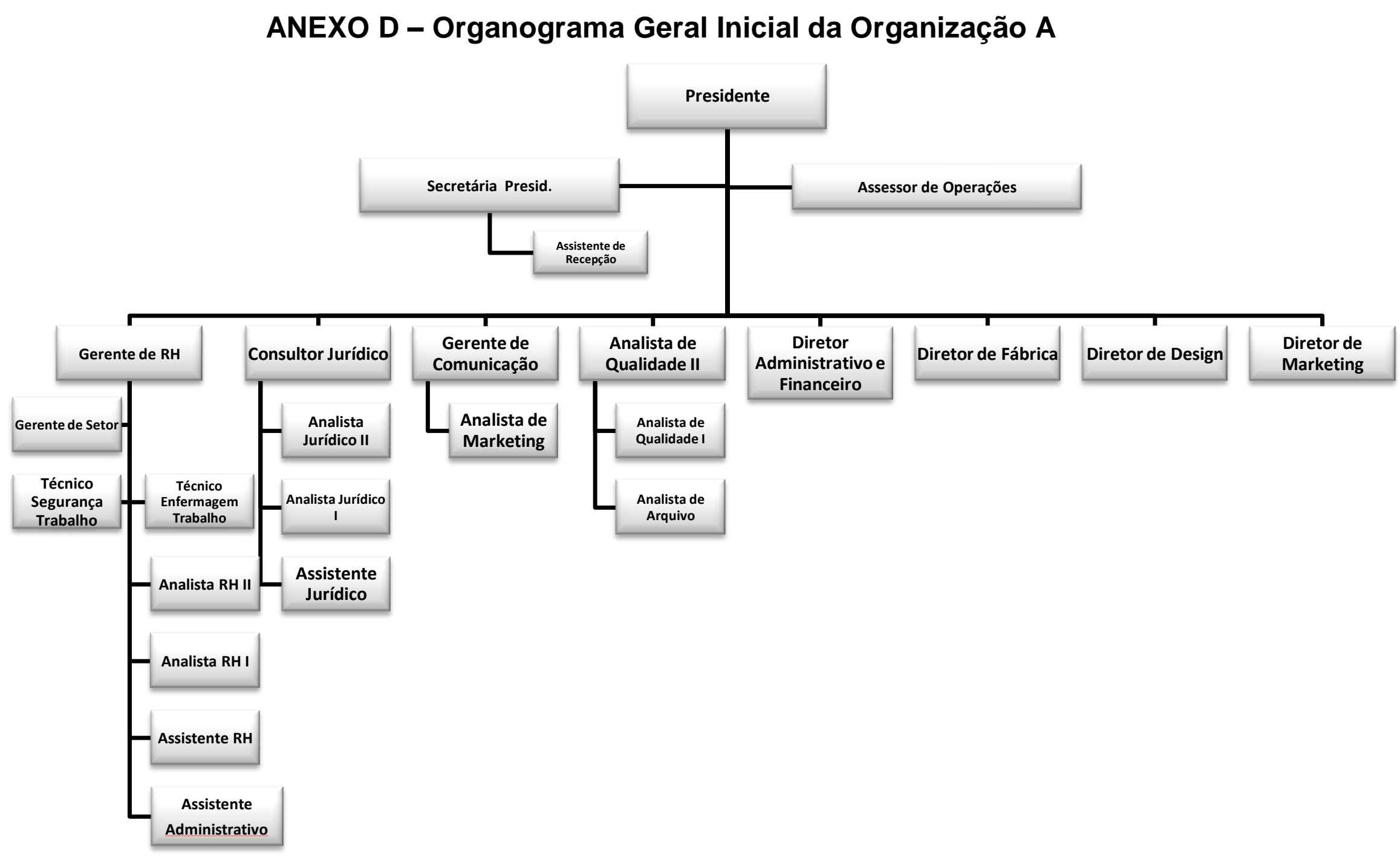

Fonte: Documento fornecido pela Organização em estudo 


\section{ANEXO E - Organograma Inicial do Setor Administrativo-Financeiro}

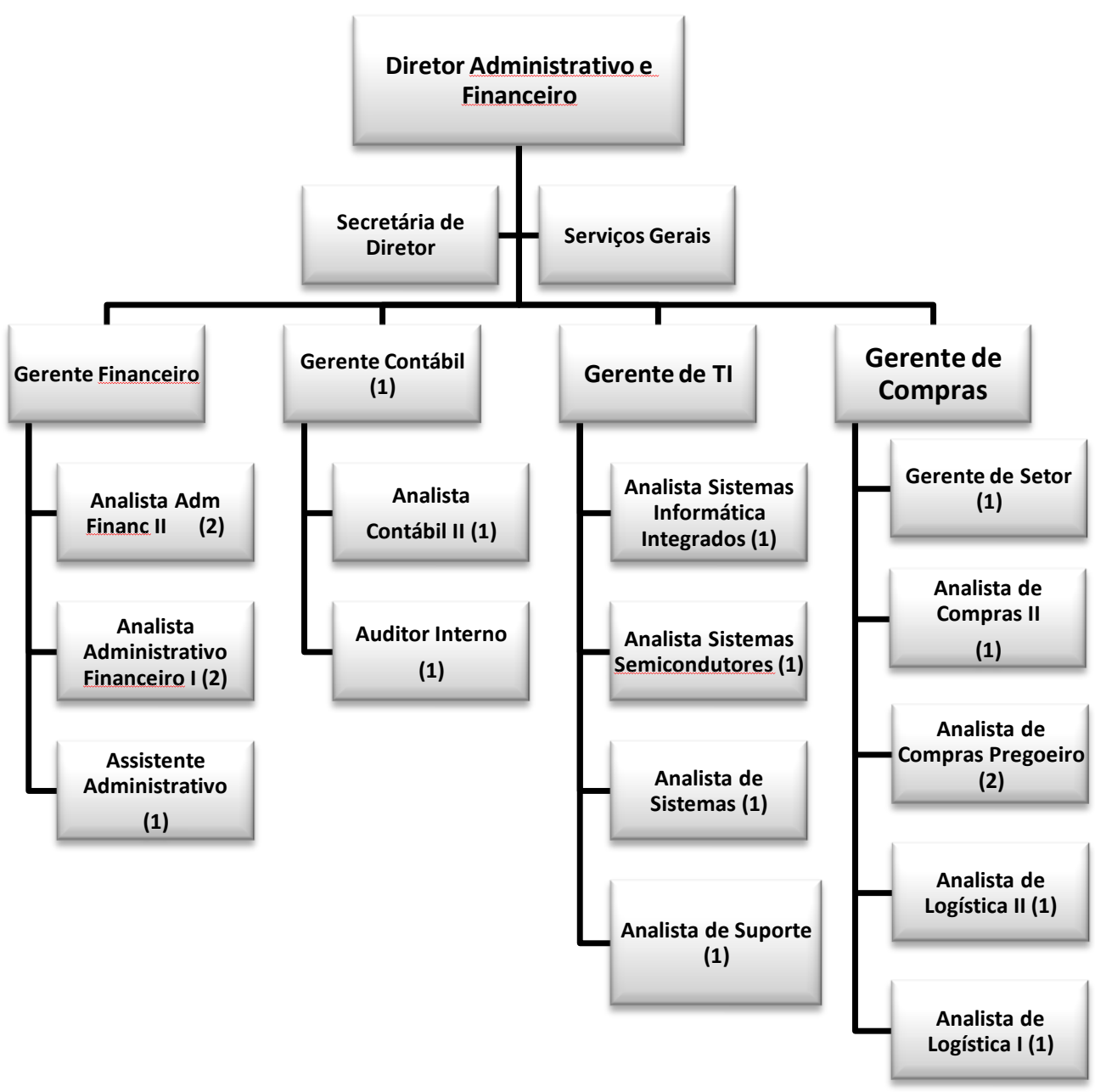

Fonte: Documento fornecido pela Organização em estudo 


\section{ANEXO F - Organograma Inicial do Setor de Marketing}

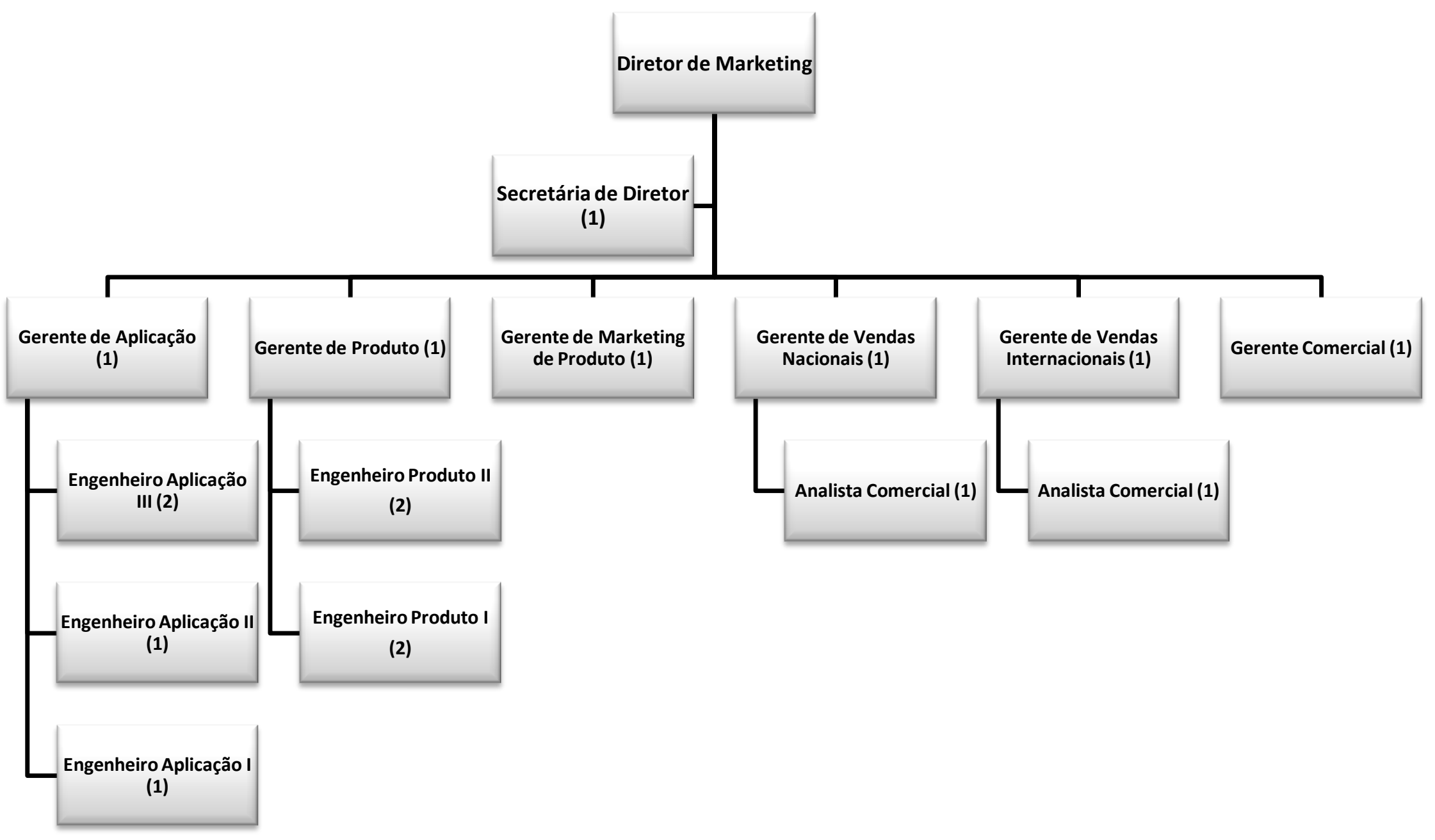

Fonte: Documento fornecido pela Organização em estudo 


\section{ANEXO G - Organograma Inicial do Setor de Design}

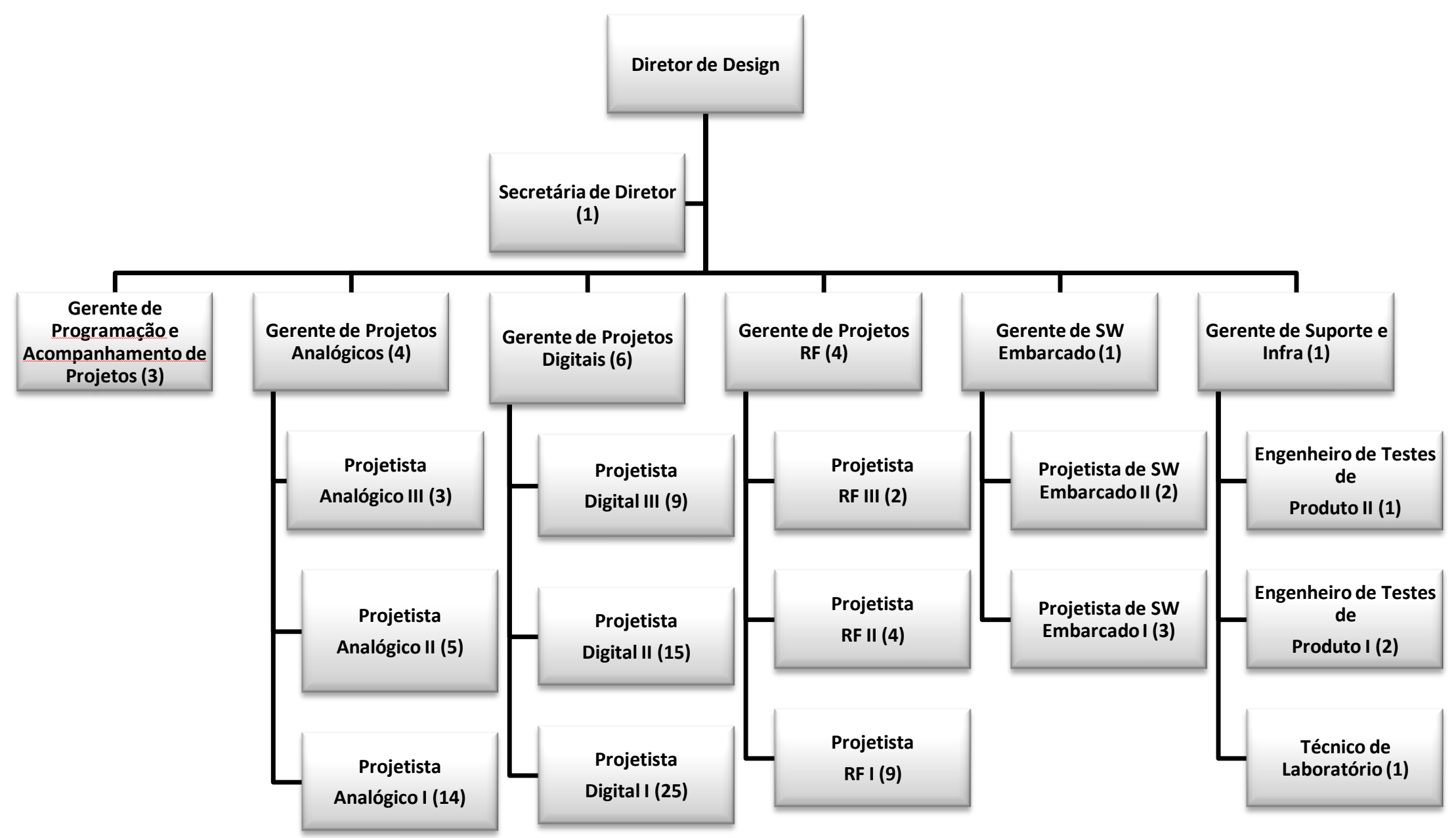

Fonte: Documento fornecido pela Organização em estudo 


\section{ANEXO H - Organograma Inicial do Setor de Fábrica}

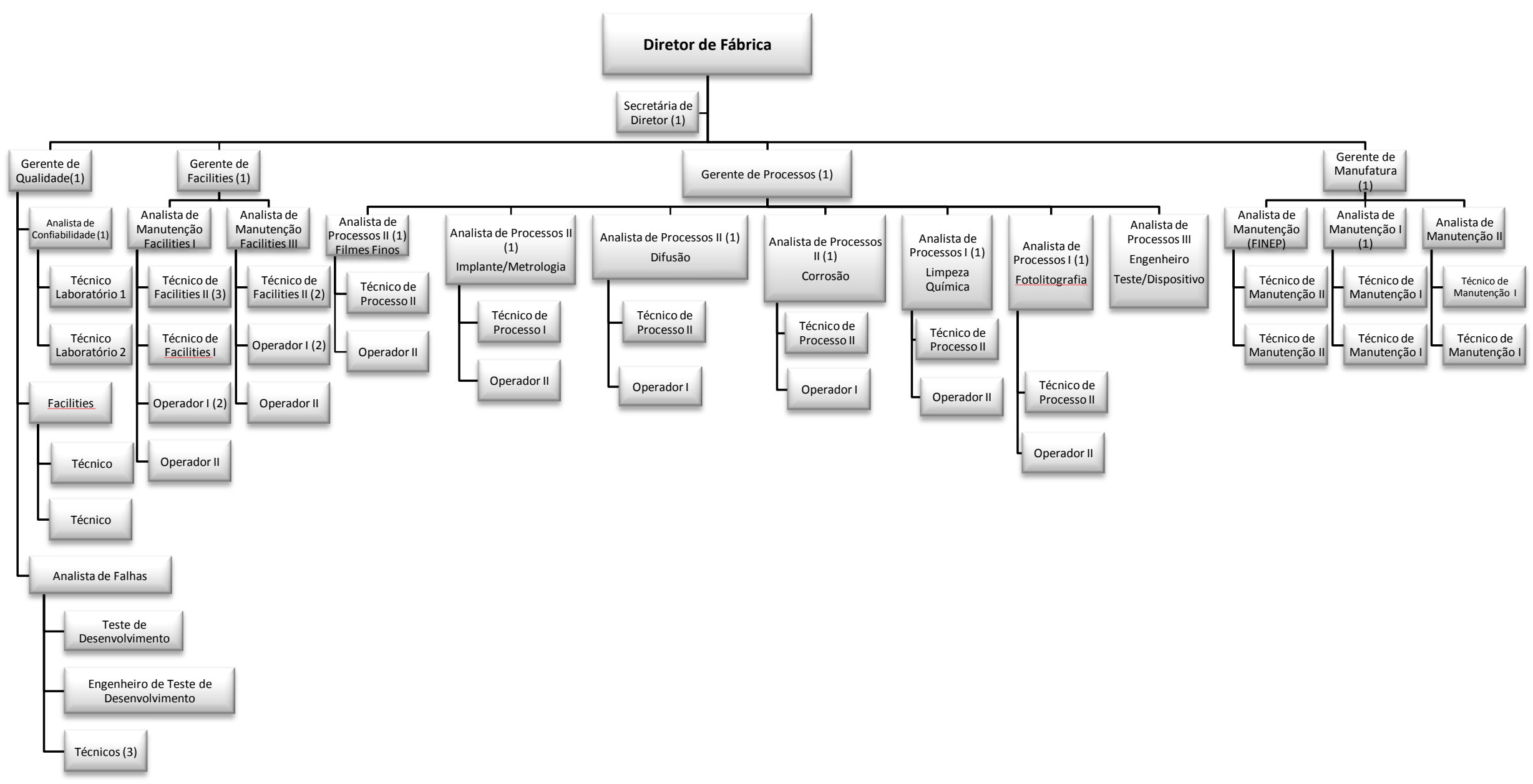

Fonte: Documento fornecido pela Organização em estudo 